\title{
Geotechnical testing and Finite Element Modeling of Geomorphic Landform Design with a Multi-Layer Cap and Cover System
}

Jeffrey R. Stevens

Follow this and additional works at: https://researchrepository.wvu.edu/etd

\section{Recommended Citation}

Stevens, Jeffrey R., "Geotechnical testing and Finite Element Modeling of Geomorphic Landform Design with a Multi-Layer Cap and Cover System" (2016). Graduate Theses, Dissertations, and Problem Reports. 6725.

https://researchrepository.wvu.edu/etd/6725

This Thesis is protected by copyright and/or related rights. It has been brought to you by the The Research Repository @WVU with permission from the rights-holder(s). You are free to use this Thesis in any way that is permitted by the copyright and related rights legislation that applies to your use. For other uses you must obtain permission from the rights-holder(s) directly, unless additional rights are indicated by a Creative Commons license in the record and/ or on the work itself. This Thesis has been accepted for inclusion in WVU Graduate Theses, Dissertations, and Problem Reports collection by an authorized administrator of The Research Repository @ WVU. For more information, please contact researchrepository@mail.wvu.edu. 
Geotechnical testing and Finite Element Modeling of Geomorphic Landform Design with a Multi-Layer Cap and Cover System

\author{
Jeffrey R. Stevens, EI \\ Thesis submitted to the \\ Benjamin M. Statler College of Engineering and Mineral Resources \\ at West Virginia University \\ in partial fulfillment of the requirements for the degree of \\ Master of Science \\ in \\ Civil and Environmental Engineering \\ John D. Quaranta, Ph.D., P.E., Chair \\ Leslie Hopkinson, Ph.D. \\ Vladislav Kecojevic, Ph.D.
}

Department of Civil and Environmental Engineering

Morgantown, West Virginia

2016

KEYWORDS: geomorphic design, soil testing, finite element computer modeling Copyright 2016 Jeffrey R Stevens 


\title{
ABSTRACT \\ Geotechnical testing and Finite Element Modeling of Geomorphic Landform Design with a Multi-Layer Cap and Cover System
}

\author{
Jeffrey R. Stevens, EI
}

This research was aimed at implementation of Geomorphic Landform Design (GLD) principles to the Royal Scot abandoned coal refuse disposal facility in Greenbrier County, West Virginia, USA. This facility currently exhibits many undesirable environmental problems including acidmine drainage and significant erosion and sediment transport.

A multi-layer cap and cover system in conjunction with GLD principles was proposed as a solution to these environmental problems. This cover is proposed to be constructed from the coarse coal refuse material on-site and a short paper fiber material ( $\mathrm{MGro}^{\mathrm{TM}}$ ) from the MeadWestVaco paper mill in nearby Covington, Virginia, USA. To determine the possible effectiveness of this design, multiple research stages were completed. First, the principles of GLD and landform covers were investigated, as well as the use and properties of coarse coal refuse combined with short paper fiber. Second, a suite of geotechnical laboratory testing was completed on the materials to be used in the construction. Third, the cap and cover system was designed based on the measured geotechnical parameters. Fourth, the cap and cover system was applied to three reclamation alternatives and its seepage control performance and geotechnical stability were analyzed by the finite element method (FEM) for slope stability and seepage using SVFlux ${ }^{\mathrm{TM}}$ and SVSlope ${ }^{\circledR}$ computer modeling software.

Geotechnical testing results concurred with literature and tended to indicate that blending short paper fiber at 40 percent with 60 percent coarse coal refuse (volumetric ratio); along with layers of $100 \%$ coarse coal refuse at Royal Scot could make an effective cap and cover system. Short paper fiber is a suitable growth media in literature and laboratory testing of a MGro ${ }^{\mathrm{TM}}$ and coarse coal refuse blended (60/40) material indicated a suitably strong material with an internal angle of friction of approximately $30^{\circ}$. The coarse coal refuse shale material $(100 \%)$ had a friction angle of $40^{\circ}$ with hydraulic conductivity values of $10^{-6}$ to $10^{-7} \mathrm{~cm} / \mathrm{s}$ when compacted to standard proctor effort. Constructing a cover with a $0.915 \mathrm{~m}(3 \mathrm{ft}$ ) thick 60/40 MGro / coarse coal refuse

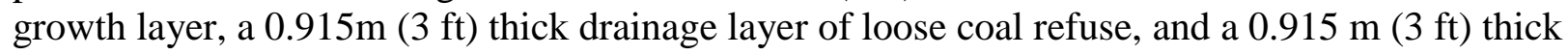
layer of compacted coal refuse. The total cap thickness was $2.75 \mathrm{~m}(9 \mathrm{ft})$ which produced a cover system capable of reducing seepage into the underlying acid-generating fill by $85 \%$. The cap and cover system was stable on slopes up to $21.8^{\circ}$.

FEM stability modeling indicated that the cover design could be applied to a design of the Royal Scot re-graded to geomorphic profiles. The design was stable, with a geotechnical factor of safety over the required minimum 1.5 on slopes less than or equal to $21.8^{\circ}$. Additionally, seepage into the acid-generating fill was shown to be reduced by nearly $75 \%$. With the addition of internal drains, which will be required on shallower slope benches of the reclamation to reduce the accumulation of internal pore water pressure, the seepage reduction was further reduced by $10 \%$, which is a nearly $85 \%$ reduction of infiltration. 


\section{ACKNOWLEDGEMENTS}

I would like to gratefully acknowledge the support of Dr. John Quaranta, an outstanding teacher, advisor, mentor, and friend who offered invaluable assistance, support, and guidance for this research project.

I wish to thank Dr. Leslie Hopkinson and Dr. Vlad Kecojevic for serving on my advisory committee.

I wish to thank Matt Minnis, Rogan Park, and Iuri Santos for their assistance with laboratory testing. I would also like to thank Harold Russell for sharing his experience with soil testing and Nathan DePriest for his help with learning how to operate the modeling software.

I would also like to acknowledge the valuable insight offered by Dr. Hema Siriwardane on the geotechnical laboratory testing and finite element computer modeling sections of this report.

Most of all, I would like to thank my amazing parents, family, and friends for all of their love and support throughout my academic career and life.

The work described in this publication was supported by Grant/Cooperative Agreement Number S15AC20020 from the Office of Surface Mining. Its contents are solely the responsibility of the authors and do not necessarily represent the official views of the OSM. 


\section{TABLE OF CONTENTS}

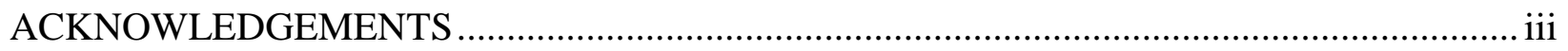

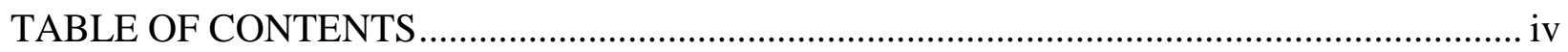

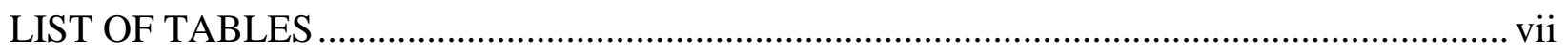

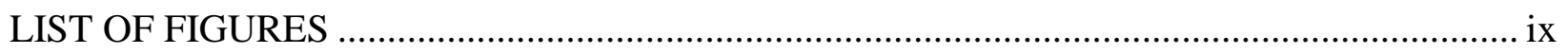

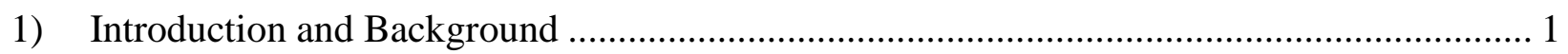

1.1) Research Motivation and Problem Statement ............................................................... 1

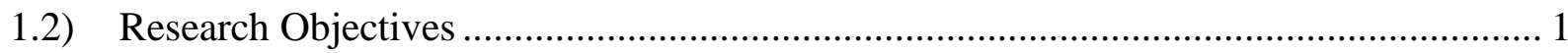

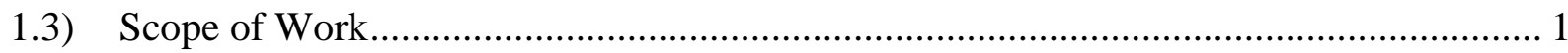

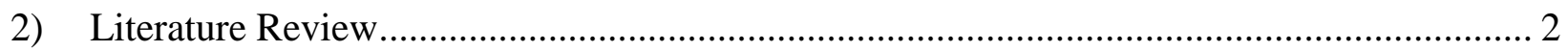

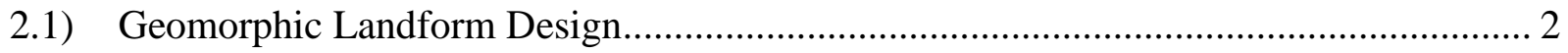

2.2) Cap and Cover Design.................................................................................. 4

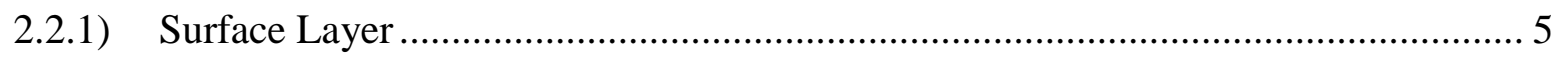

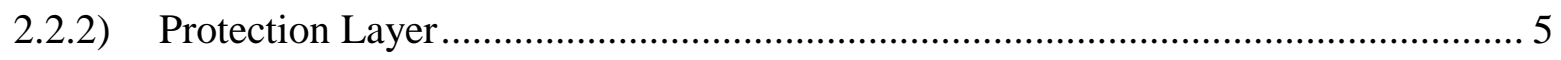

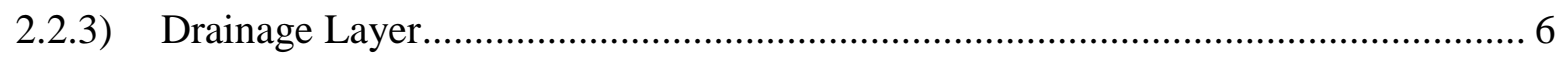

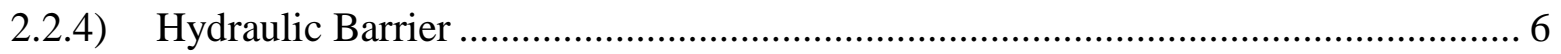

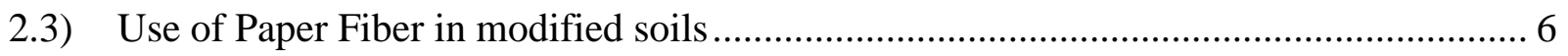

2.4) Coarse Coal Refuse Geotechnical Testing ................................................................ 8

2.5) Short Paper fiber (paper mill sludge) Geotechnical Testing ......................................... 10

2.6) Slope Stability and Seepage Numerical Modeling...................................................... 11

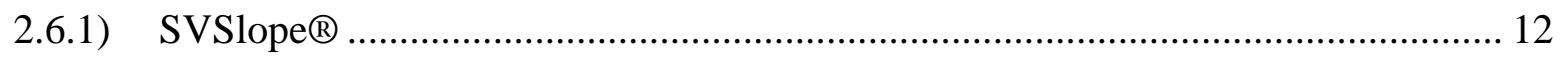

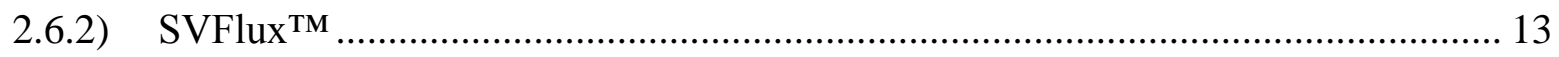

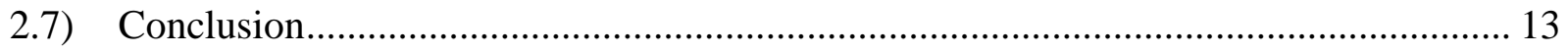

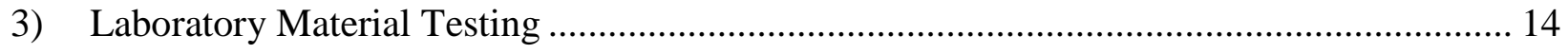

3.1) Coarse Coal Refuse Material Testing....................................................................... 14

3.1.1) Material Description .................................................................................... 15

3.1.2) Moisture Content .................................................................................... 16

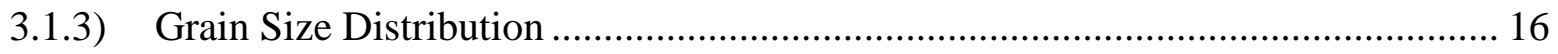

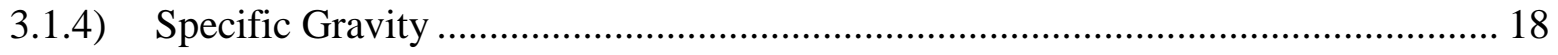

3.1.5) Atterberg Limits.................................................................................. 19

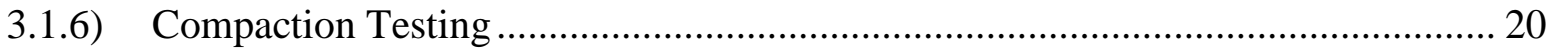

3.1.7) Hydraulic Conductivity testing ...................................................................... 21 


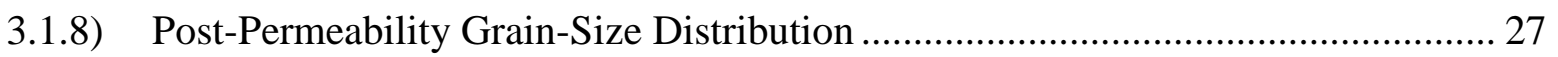

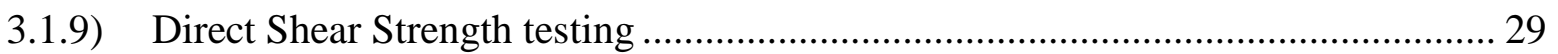

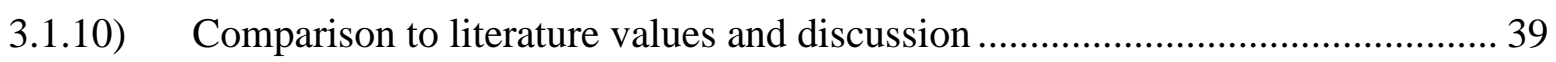

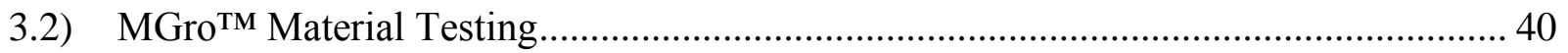

3.2.1) Visual Inspection ................................................................................. 40

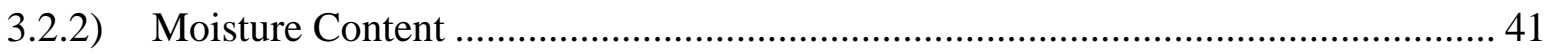

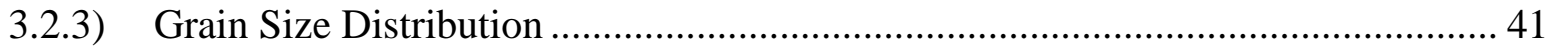

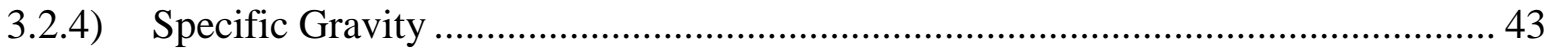

3.2.5) Compaction ............................................................................................ 44

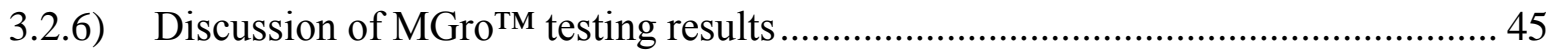

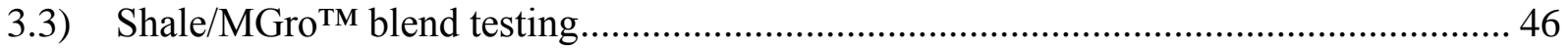

3.3.1) Grain Size Distributions............................................................................... 47

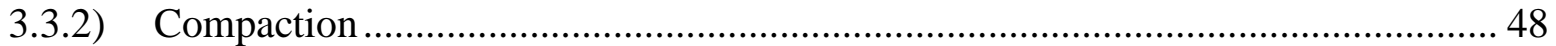

3.3.3) Permeability ……………….................................................................. 49

3.3.4) Strength Testing (Consolidated Undrained Triaxial)............................................. 51

3.4) Summary of Laboratory Testing ………………........................................................ 55

4) Design and Modeling of Cap and Cover System.............................................................. 57

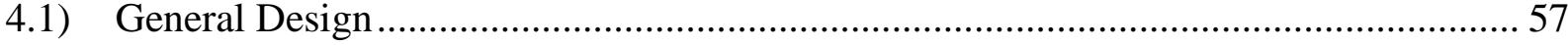

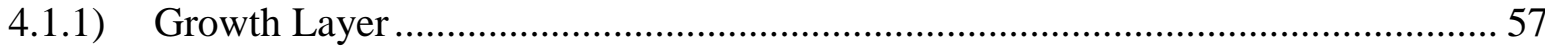

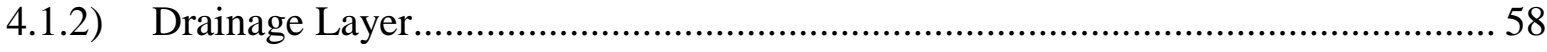

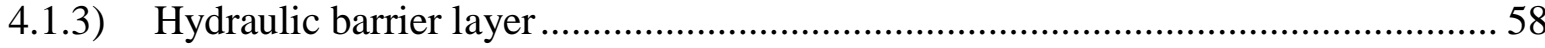

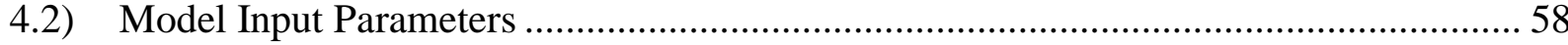

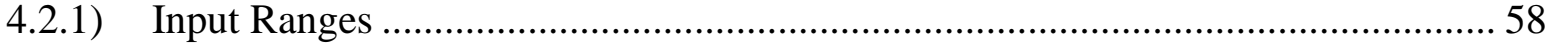

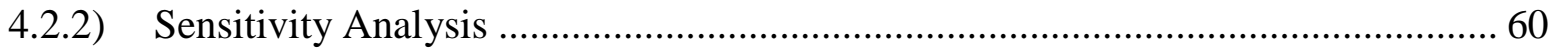

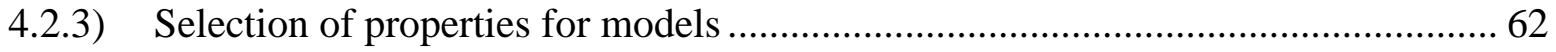

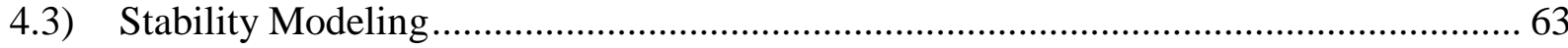

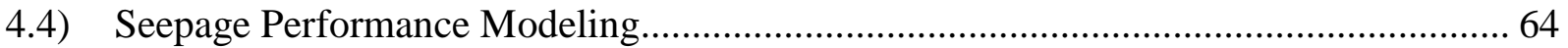

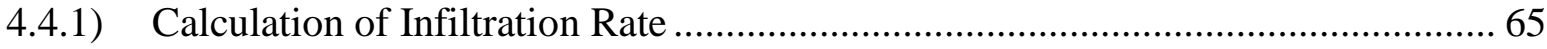

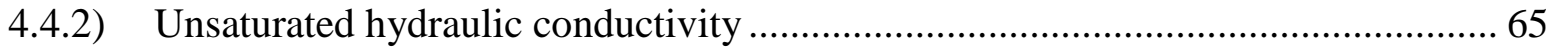

4.4.3) Sensitivity analysis from two-year transient model............................................... 68

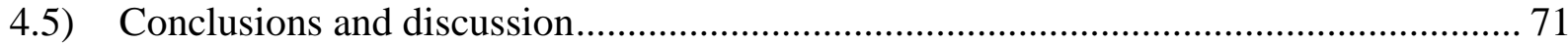

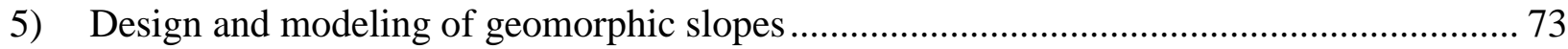

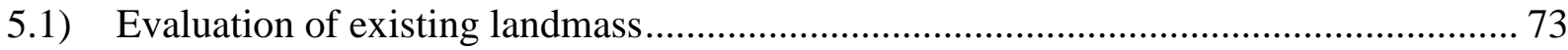

5.2) Design Iteration 1 (Conventional bench-slope design) ………...................................... 75 


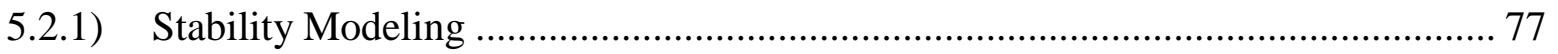

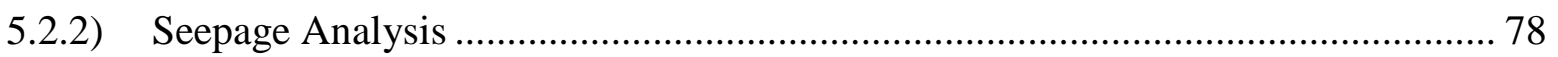

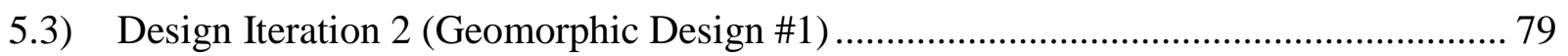

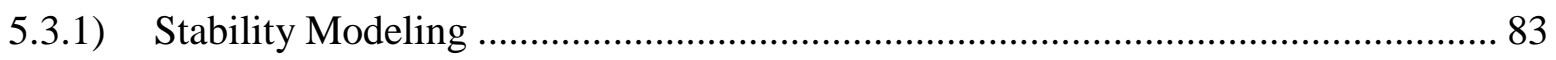

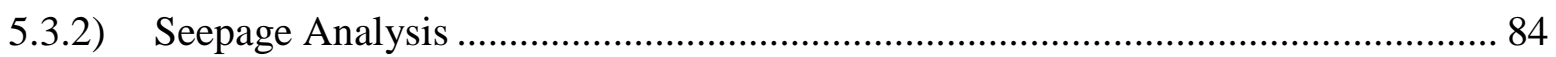

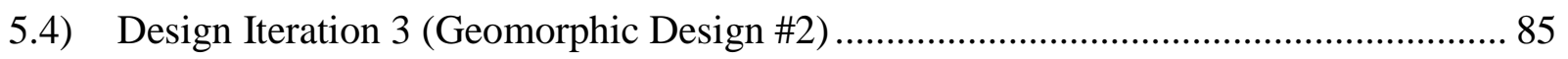

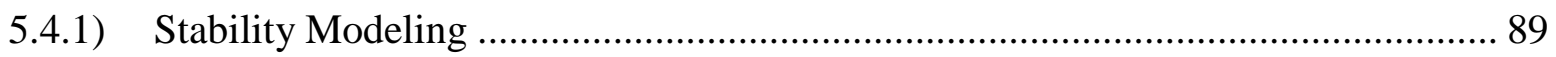

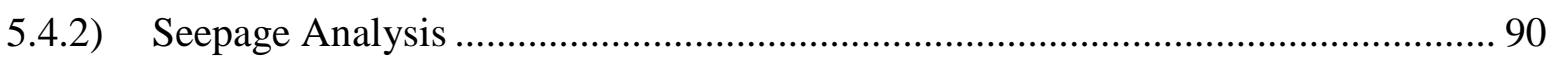

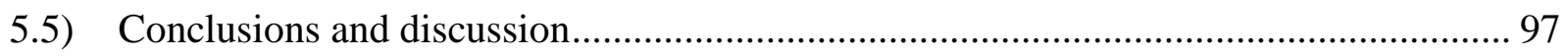

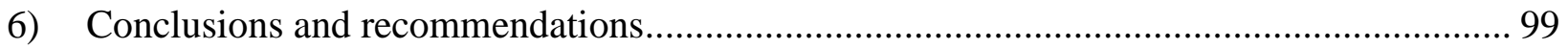

6.1) Outcome 1: Geotechnical Material Properties ………………………………............ 99

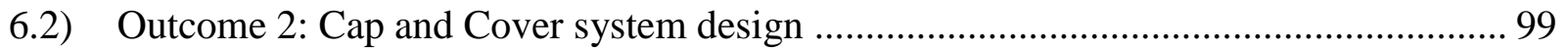

6.3) Outcome 3: Application to Reclamation Alternatives ................................................. 100

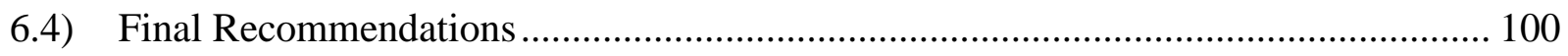

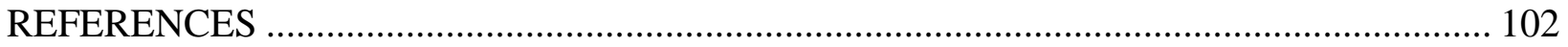

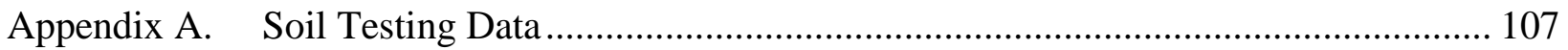

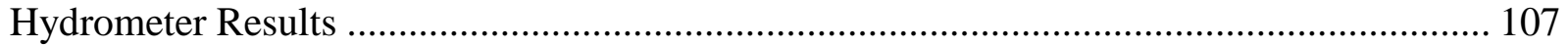

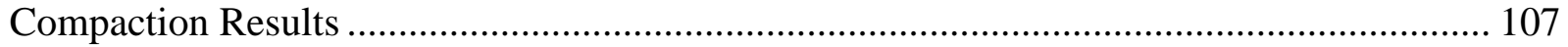

Direct Shear Testing Results....................................................................................... 115

Standard Proctor Specimens ………………………………………………………..... 115

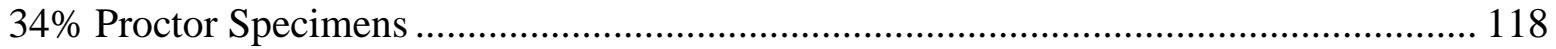

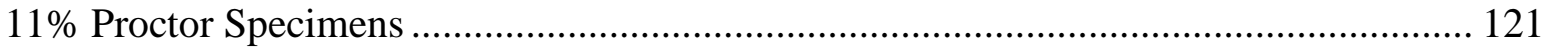




\section{LIST OF TABLES}

Table 2.1: Index properties for coarse coal refuse from Hegazy et al. (2004) ............................. 8

Table 2.2: Strength properties for coarse coal refuse from Hegazy et al. (2004) ........................ 9

Table 2.3: Summary of Geotechnical properties from Table 6.3 of D'Appolonia (2009) ............ 9

Table 2.4: Summary of geotechnical properties from Quaranta and Tolikonda (2011) .............. 10

Table 2.5: Basic Geotechnical properties from Moo-Young and Zimmie (1996)...................... 10

Table 2.6: Summary of compaction, strength and permeability results from Moo-Young and

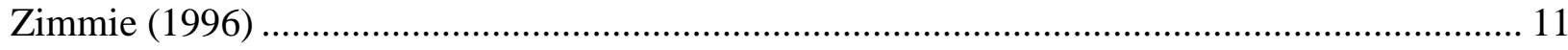

Table 3.1: Summary of geotechnical tests completed ................................................... 14

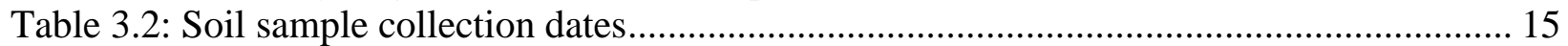

Table 3.3: Critical Indices for shale as-received GSD .................................................... 17

Table 3.4: Uniformity Coefficient Statistics .................................................................... 17

Table 3.5: Coefficient of Gradation Statistics.................................................................... 17

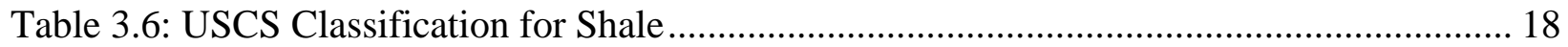

Table 3.7: Test Statistics for specific gravity of soil solids .................................................. 18

Table 3.8: Determination of plastic limit, liquid limit, and plasticity index............................ 19

Table 3.9: Summary of compaction test results .................................................................. 20

Table 3.10: Hydraulic Conductivity test results and specimen data for $592.5 \mathrm{~kJ} / \mathrm{m}^{3}$ compacted

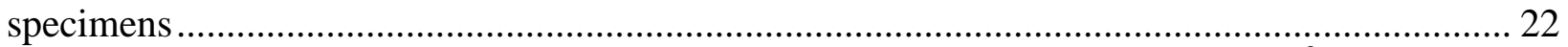

Table 3.11: Hydraulic Conductivity test results and specimen data for $67.85 \mathrm{~kJ} / \mathrm{m}^{3}$ compacted

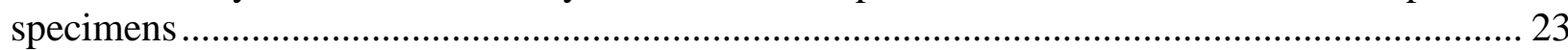

Table 3.12: Hydraulic Conductivity test results and specimen data for $1185 \mathrm{~kJ} / \mathrm{m}^{3}$ compacted

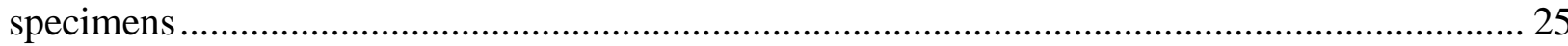

Table 3.13: Summary of Hydraulic Conductivity test results............................................. 26

Table 3.14: Comparison of grain-size distribution before and after compaction and permeability

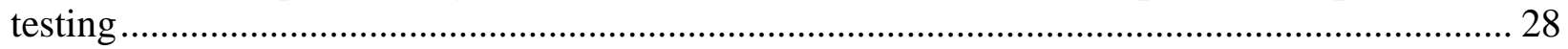

Table 3.15: Testing conditions for Direct Shear tests ....................................................... 30

Table 3.16: Average properties of compaction molds used for direct shear specimens compacted

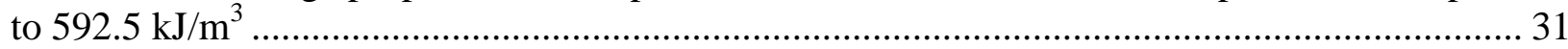

Table 3.17: Summary of Direct Shear results at each normal stress test point.......................... 32

Table 3.18: Average properties of compaction molds used for direct shear specimens compacted

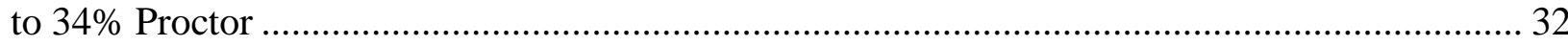

Table 3.19: Statistics for Direct Shear tests of specimens compacted to 34\% Proctor energy..... 33 Table 3.20: Average properties of compaction molds used for direct shear specimens compacted

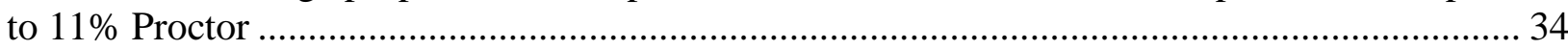

Table 3.21: Direct shear test statistics for specimens compacted to $11 \%$ Proctor energy ........... 35

Table 3.22: Summary of all direct shear test results (all stresses effective) ............................. 36

Table 3.23: Summary of differences between direct shear compaction mold specimens and

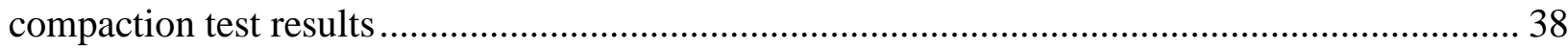

Table 3.24: Comparison of coarse coal refuse lab testing values to literature values ................. 39

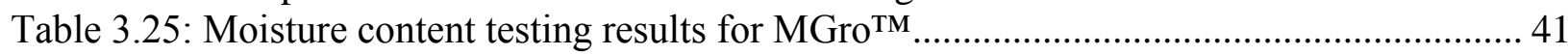

Table 3.26: Critical Indices from MGro ${ }^{\mathrm{TM}}$ grain size testing ............................................. 42

Table 3.27: Uniformity Coefficient Statistics from MGro ${ }^{\mathrm{TM}}$ grain size testing ........................ 42

Table 3.28: Coefficient of Gradation Statistics from MGro ${ }^{\text {TM }}$ grain size testing ...................... 42

Table 3.29: USCS Classification for dried MGro ${ }^{\mathrm{TM}}$........................................................... 42 
Table 3.30: MGro $^{\text {TM }}$ Specific gravity test 1 results and statistics......................................... 43

Table 3.31: MGro $^{\text {TM }}$ Specific gravity test 2 results and statistics............................................ 44

Table 3.32: Critical Indices for blend grain size distribution tests ......................................... 47

Table 3.33: Summary of compaction test results of Royal Scot materials ............................... 49

Table 3.34: Specimen data and hydraulic conductivity test results for $60 / 40$ blend .................. 50

Table 3.35: Summary of triaxial testing conditions ...................................................... 51

Table 3.36: Summary of Geotechnical testing results ...................................................... 55

Table 4.1: Average properties for cap and cover materials from laboratory testing ................... 58

Table 4.2: Calculated standard deviations and range of values within 2 standard deviations of the

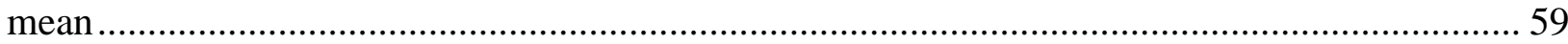

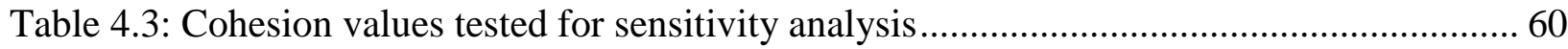

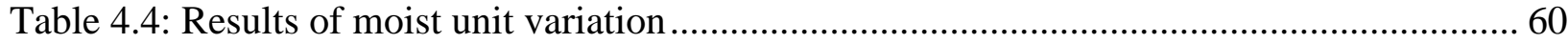

Table 4.5: Results of friction angle variation.............................................................. 61

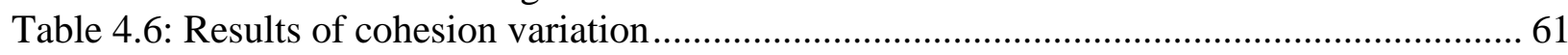

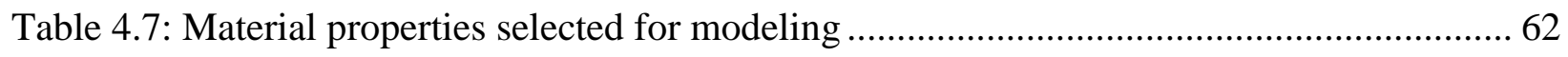

Table 4.8: Seepage modeling results to evaluate effect of thickness and hydraulic conductivity

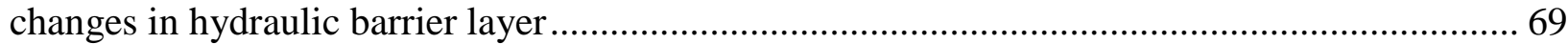

Table 4.9: Classification system for decision of hydraulic barrier effectiveness ...................... 69

Table 5.1: Summary of slope measurement descriptions ................................................... 73

Table 5.2: Seepage model result summary for iteration 1 conventional design ....................... 79

Table 5.3: Seepage model result summary for iteration 2 critical slope ................................. 85

Table 5.4: Summary of seepage results for iteration 3 steep slope ...................................... 93

Table 5.5: Summary of seepage results from shallow slope of iteration 3 ............................. 94

Table 5.6: Decision table with Chapter 5 modeling summary............................................ 98

Table A.1: Shale sample hydrometer data .................................................................... 107

Table A.2: Compaction Test Results- Standard Proctor Effort ............................................ 108

Table A.3: Compaction Test Results- 34\% Standard Proctor Effort ........................................ 109

Table A.4: Compaction Test Results: 11\% Standard Proctor Effort ...................................... 110

Table A.5: Compaction Test Results- 200\% Standard Proctor Effort .................................... 111

Table A.6: Compaction test data for MGro $^{\mathrm{TM}}$................................................................. 112

Table A.7: Sample test data for 60/40 blend standard proctor compaction ............................. 113

Table A.8: Test data for 80/20 blend standard proctor compaction ...................................... 114

Table A.9: Compiled direct shear testing results for specimens compacted to Standard Proctor

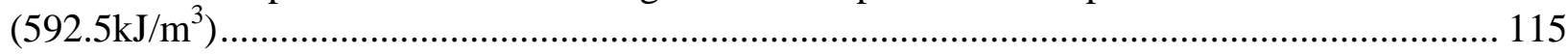

Table A.10: Compiled direct shear testing results for all specimens compacted to $34 \%$ of standard proctor effort.......................................................................................... 118

Table A.11: Compiled direct shear testing results for all specimens compacted to $67.85 \mathrm{~kJ} / \mathrm{m}^{3} 121$ 


\section{LIST OF FIGURES}

Figure 1.1: Coal refuse disposal sites in West Virginia with Royal Scot research site (bold circle)

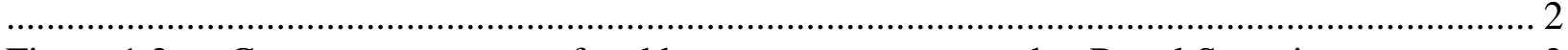

Figure 1.2: a. Current appearance of and b. water treatment pond at Royal Scot site.................. 2

Figure 2.1: Typical landfill cover system (Bonaparte et al., 2004) ............................................ 5

Figure 3.1: Shale Sample location at Royal Scot site (ESRI, 2015) ....................................... 15

Figure 3.2: Typical coarse coal refuse sample (tape measure in inches) ................................. 16

Figure 3.3: Grain-size distribution for shale material ................................................. 18

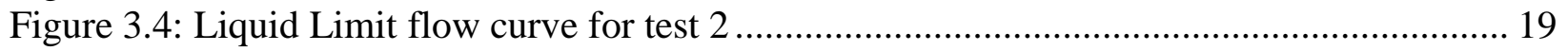

Figure 3.5: Compilation of shale compaction testing results............................................... 21

Figure 3.6: Hydraulic conductivity vs. pore volume plot for specimens compacted to Standard

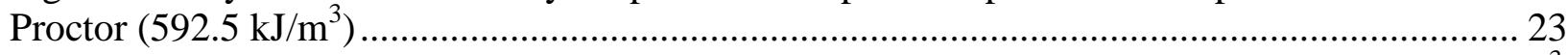

Figure 3.7: Hydraulic conductivity vs. pore volume plot for specimens compacted to $67.85 \mathrm{~kJ} / \mathrm{m}^{3}$

Figure 3.8: Hydraulic conductivity vs. pore volume plot for specimens compacted to $1185 \mathrm{~kJ} / \mathrm{m}^{3}$

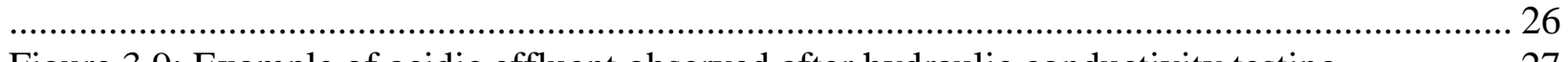

Figure 3.9: Example of acidic effluent observed after hydraulic conductivity testing ................ 27

Figure 3.10: Post-permeability grain size distribution for shale standard compacted specimens 28

Figure 3.11: Representative Royal Scot slope cross-section ............................................. 30

Figure 3.12: Combined shear stress vs. normal stress plots for all specimens compacted to 592.5

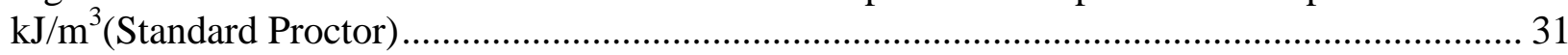

Figure 3.13: Combined shear stress vs. normal stress plots for all specimens compacted to 203.6

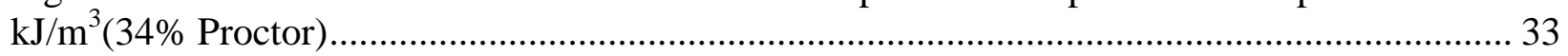

Figure 3.14: Combined shear stress vs. normal stress plots for specimens compacted to 67.85

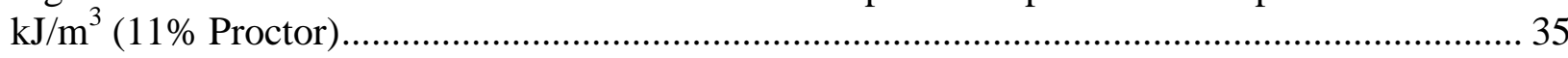

Figure 3.15: Shear Stress vs. shear strain plot for shale direct shear specimens compacted to $34 \%$

of standard proctor energy under deep loading condition. ................................................ 37

Figure 3.16: Shear Stress vs. shear strain plot for shale direct shear specimens compacted to $34 \%$

of standard proctor energy under shallow (surface) loading condition. .................................. 37

Figure 3.17: Typical MGro ${ }^{\text {TM }}$ sample.......................................................................... 41

Figure 3.18: As Received Grain Size Distribution- Dried MGro ${ }^{\mathrm{TM}}$ material ............................ 43

Figure 3.19: MGro $^{\mathrm{TM}}$ Compaction Curve for Standard Proctor effort ..................................... 45

Figure 3.20: Grain Size Distributions for Royal Scot materials (4.76mm topsize) ................... 48

Figure 3.21: Compaction curves for shale, MGro, and blended materials at standard proctor

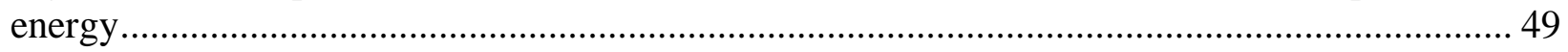

Figure 3.22: Hydraulic conductivity vs. pore volumes plot for $60 / 40$ blend ............................. 50

Figure 3.23: Triaxial testing apparatus during shearing of a specimen ................................. 52

Figure 3.24: Stress Strain Curve from triaxial test of 60/40 blend with failure points noted....... 53

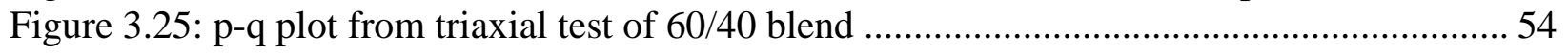

Figure 4.1: Proposed Cap and Cover design layers .......................................................... 57

Figure 4.2: 2:1 slope used for sensitivity analysis with average properties and zero cohesion.... 62

Figure 4.3: Stability modeling results for cover on 2:1 slope with selected properties............... 63

Figure 4.4: 2.5 to 1 slope with base cover design and selected properties ................................ 64

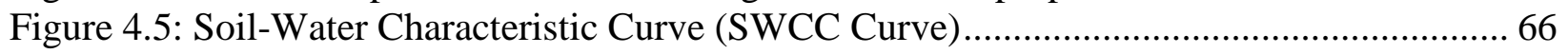

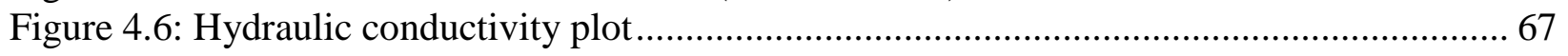


Figure 4.7: 2.5 to 1 slope used in seepage modeling to evaluate cap and cover system ............. 68

Figure 4.8: Seepage model for 5 foot hydraulic barrier layer and low hydraulic conductivity .... 70

Figure 4.9: Seepage model for 5 foot hydraulic barrier layer and high hydraulic conductivity ... 71

Figure 5.1: Slope analysis and critical slope location of existing fill .................................. 75

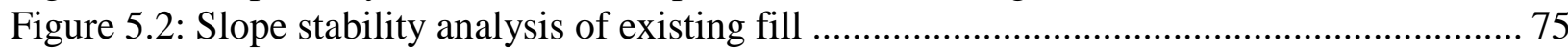

Figure 5.3: Plan view and critical slope of conventional design ........................................ 76

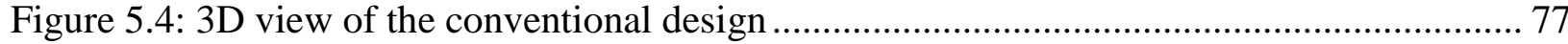

Figure 5.5: Stability Modeling results for conventional design............................................ 78

Figure 5.6: Seepage modeling results for conventional design ........................................... 78

Figure 5.7: Seepage modeling results and water streamtrace paths for conventional design after

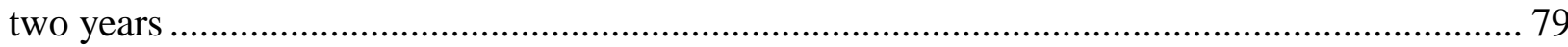

Figure 5.8: Plan view of Iteration \#2- first geomorphic design ........................................ 80

Figure 5.9: 3D rendering of Iteration \#2- first geomorphic design.................................... 81

Figure 5.10: Slope zone analysis and location of critical slope on second design iteration ......... 82

Figure 5.11: Geometric profile of slope cross-section for Iteration \#2 .................................... 83

Figure 5.12: Slope stability analysis for iteration \#2 and failure surfaces with FOS $<1.5$.......... 84

Figure 5.13: Seepage modeling results for iteration 2 slope with water flow path streamlines ... 85

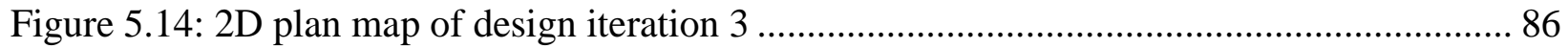

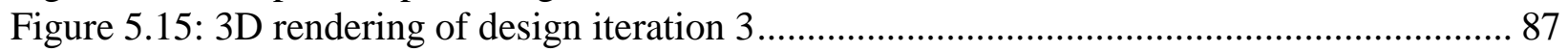

Figure 5.16: Slope analysis and critical slope of design iteration 3................................... 88

Figure 5.17: Cross-section of slope modeled on design iteration 3 (units in feet) .................... 89

Figure 5.18: Slope stability analysis for slope modeled on design iteration 3 ........................ 90

Figure 5.19: Two-year seepage results for iteration 3 steep slope ...................................... 91

Figure 5.20: Iteration 3 slope degree of saturation and flow streamlines ............................... 91

Figure 5.21: Close-up of Iteration 3 slope toe .............................................................. 92

Figure 5.22: Proposed drain location for iteration 3 steep slope ........................................ 92

Figure 5.23: Seepage model pore pressure for shallow slope of iteration 3 ............................ 93

Figure 5.24: Seepage model flowpaths for shallow slope of iteration 3 ................................. 94

Figure 5.25: Seepage model results for steep slope immediately after 100-year, 24-hour design

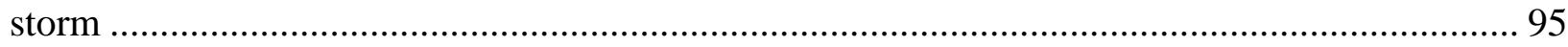

Figure 5.26: Stability model results for steep slope immediately after 100-year, 24-hour design

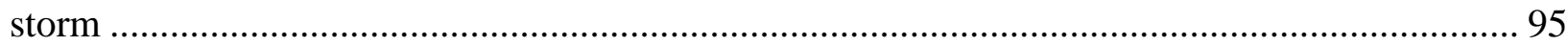

Figure 5.27: Seepage model results for shallow slope immediately after 100-year, 24-hour storm

Figure 5.28: Stability model results for shallow slope immediately after 100-year, 24-hour storm

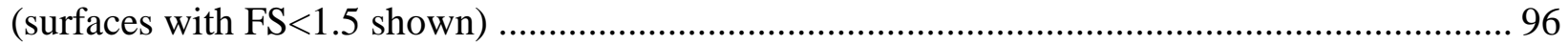

Figure 5.29: Stability model results for shallow slope one day after 100-year, 24-hour storm.... 97

Figure A.1: Particle size curve from Hydrometer for CCR shale ........................................ 107

Figure A.2: Standard Proctor Curve with lines at 100\% and 90\% saturation.......................... 108

Figure A.3: 34\% Proctor Curve with lines at 100\% and 90\% saturation ................................ 109

Figure A.4: 11\% Proctor Curve with lines at 100\% and 90\% saturation ............................... 110

Figure A.5: 200\% Proctor Curve with lines at 100\% and 90\% saturation ............................. 111

Figure A.6: Compaction Curve for 60/40 blend at standard proctor effort $(592.5 \mathrm{~kJ} / \mathrm{m} 3) \ldots \ldots \ldots 113$

Figure A.7: Compaction curve for 80/20 blend standard proctor tests ................................ 114

Figure A.8: Shear stress vs. shear strain plot for shale standard compacted direct shear specimens

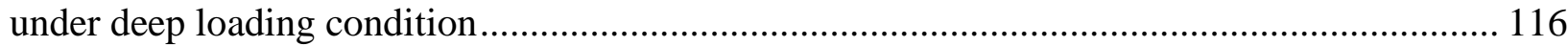


Figure A.9: Shear stress vs. shear strain for shale standard proctor compacted direct shear specimens under medium loading condition.

Figure A.10: Shear stress vs. shear strain plot for shale standard proctor compacted direct specimens under low loading condition

Figure A.11: Shear stress vs. shear strain plot for CCR standard compacted direct shear specimens under surface loading

Figure A.12: Shear Stress vs. shear strain plot for shale direct shear specimens compacted to $34 \%$ of standard proctor energy under deep loading condition.

Figure A.13: Shear Stress vs. shear strain plot for shale direct shear specimens compacted to $34 \%$ of standard proctor energy under medium loading condition.

Figure A.14: Shear Stress vs. shear strain plot for shale direct shear specimens compacted to $34 \%$ of standard proctor energy under low (one bench) loading condition.

Figure A.15: Shear Stress vs. shear strain plot for shale direct shear specimens compacted to $34 \%$ of standard proctor energy under shallow (surface) loading condition.

Figure A.16: Shear Stress vs. shear strain plot for shale direct shear specimens compacted to $11 \%$ of standard proctor energy under deep loading condition.

Figure A.17: Shear Stress vs. shear strain plot for shale direct shear specimens compacted to $11 \%$ of standard proctor energy under deep loading condition.

Figure A.18: Shear Stress vs. shear strain plot for shale direct shear specimens compacted to $11 \%$ of standard proctor energy under deep loading condition.

Figure A.19: Shear Stress vs. shear strain plot for shale direct shear specimens compacted to $11 \%$ of standard proctor energy under deep loading condition. 


\section{1) INTRODUCTION AND BACKGROUND}

\section{1) Research Motivation and Problem Statement}

Coal mining and refuse disposal have profound impacts on the landscape of Appalachia. Active coal refuse disposal areas occupy thousands of acres in West Virginia and Virginia with abandoned sites found in nearly every major watershed. If these refuse disposal sites are not reclaimed correctly, they can create significant problems for the local environment (Daniels et al., 1996).

There are many problems related to improperly disposed refuse. These include pollution of surface and groundwater by acidic leachates and runoff, erosion and sedimentation of water bodies, spontaneous combustion, and landslides. Most, if not all, of these problems can be minimalized or prevented through proper landform and surface cover design (Daniels et al., 1996).

Research has shown that a process known as geomorphic landform design (GLD) offers potential to offset negative impacts of surface mining valley fill sites in Appalachia, which present similar challenges to coal refuse disposal facilities (eg. Michael et al., 2010; Sears et al., 2013; Sears et al., 2014; Russell et al., 2014, DePriest, 2015). When compared to conventional reclamation approaches, GLD creates landforms attempt to mimic the natural equilibrium of erosive forces found in mature landforms (Schor and Gray, 2007). The result is landforms which are more aesthetically pleasing, more geotechnically stable, and require less maintenance than conventional designs. Applications of this method have primarily been in the western United States and abroad, despite the benefits that geomorphic landform design offers and more widespread acceptance in the scientific community (Nicolau, 2003).

In this study, problems related to the site specific application of geomorphic landform design will be explored at a coal refuse disposal site in Greenbrier County, West Virginia hereafter referred to as the Royal Scot site. The location of the Royal Scot site is shown in Figure 1.1 along with numerous refuse disposal sites in the state. Royal Scot has been abandoned since 1999 and presents many environmental problems (Ward, 2001). There is little vegetation present on the coal refuse material and an elaborate water treatment system is required to prevent major reduction of water quality from acid-mine drainage in nearby streams. Additionally, the site presents unique challenges with its ridge-top location with a surface elevation over $1130 \mathrm{~m}$ (3700 feet). Figure 1.2 shows the current appearance of the site and one of the water treatment ponds on site. In 2001, it was estimated that water treatment costs at the site for the West Virginia Department of Environmental Protection, who currently controls the site, amounted to $\$ 220,000$ (Ward, 2001). 


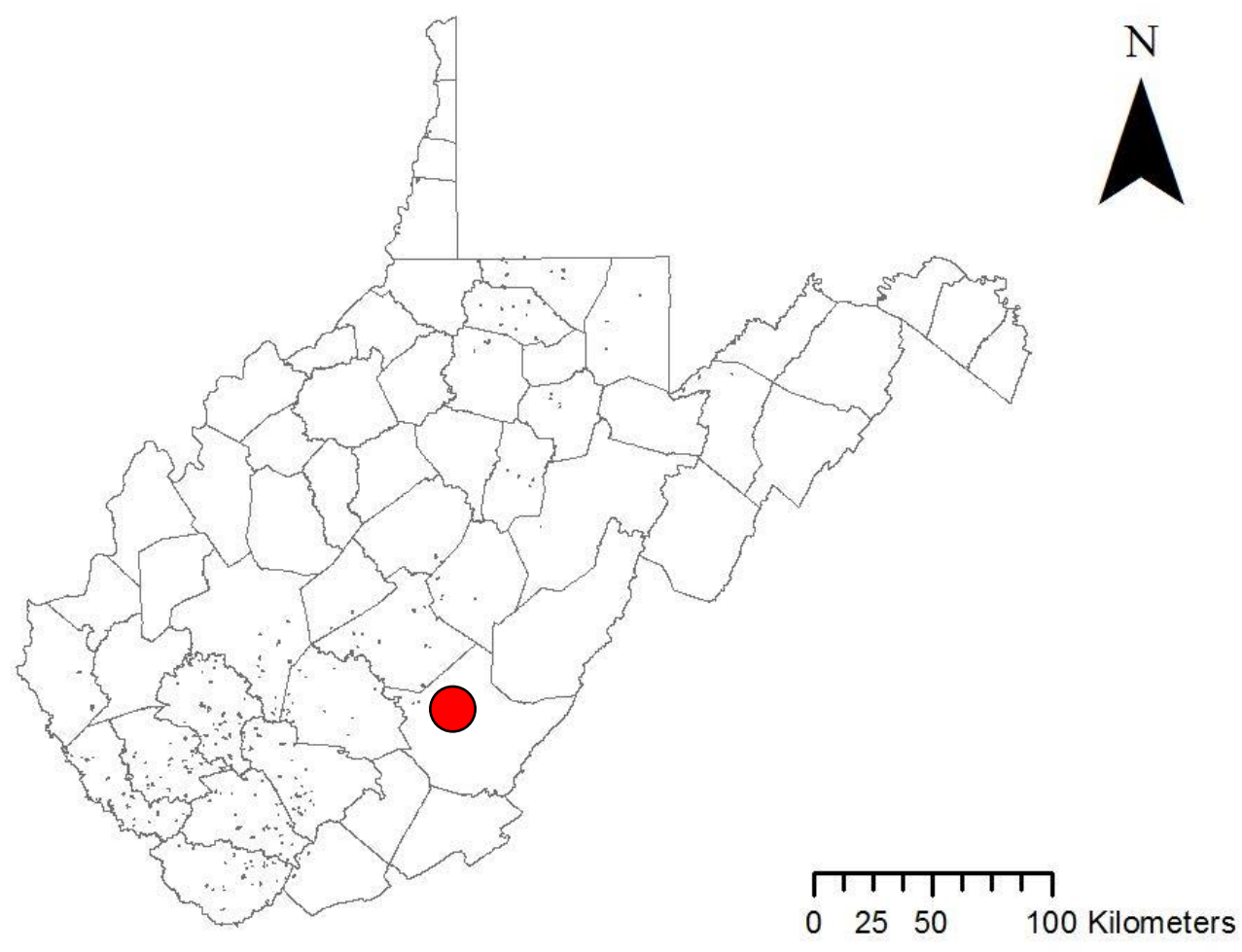

Figure 1.1: Coal refuse disposal sites in West Virginia with Royal Scot research site (bold circle)

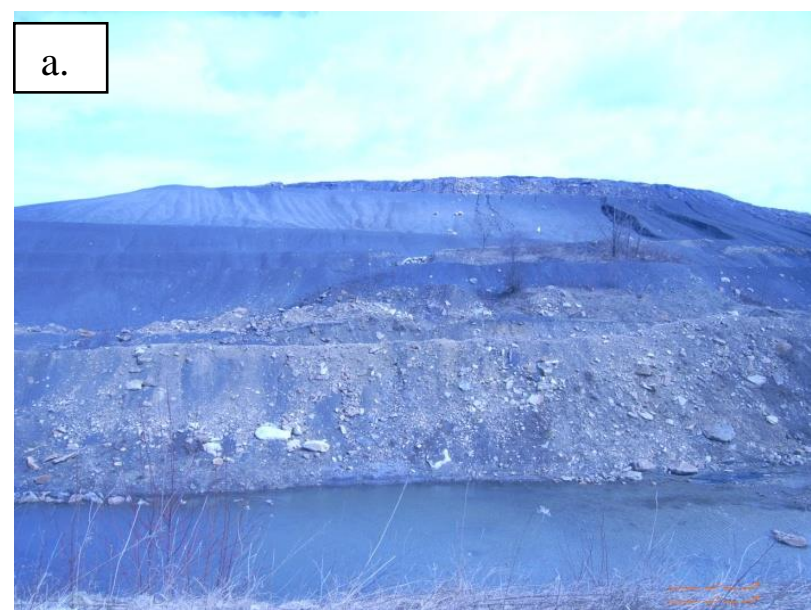

b.

Figure 1.2: a. Current appearance of and $b$. water treatment pond at Royal Scot site 


\section{2) Research Objectives}

The objective of this research was to explore the site-specific application of geomorphic landform design to the Royal Scot refuse site in Greenbrier County, West Virginia. A cap and cover system was designed as a reclamation method to minimize infiltration of rainwater into the main body of coal refuse and to be structurally stable.

\section{3) Scope of Work}

The reclamation designs were analyzed and evaluated by finite-element computer modeling for infiltration, seepage, and geotechnical stability for candidate covers. The modeling will focus at critical slopes of the geomorphic reclamation. Specific components of this research project include the following work elements:

1. Research published literature of previous applications of short paper fiber (paper mill residuals) used as cap and cover system and integrated with geomorphic landform design

2. A comprehensive laboratory soil testing program to define the geotechnical properties of the coarse coal refuse found on-site, short paper fiber, and a volumetric blending of the two materials

3. Finite-element computer model using laboratory soil properties for design and analysis of the multi-layer cap and cover system to optimize parameters to reduce infiltration into the coal refuse fill

4. The cap and cover design system was applied to several reclamation alternatives incorporating geomorphic principles and finite element computer modeling used to evaluate and optimize barrier performance and geotechnical stability and safety.

Work Scope items: 1, 2, and 3 were completed in chapters 2, 3, 4, and 5, respectively. 


\section{2) LITERATURE REVIEW}

\section{1) Geomorphic Landform Design}

The investigation of geomorphic landform design begins with Nicolau (2003), which reviewed the current trends and future possibilities of surface mine reclamation. The study notes two primary approaches in reclamation. In the first and most common approach, the goal is to design relief such that a minimal quantity of runoff and sediment is exported to water bodies off site. This design method yields structures which are geotechnically stable (as indicated by factor of safety or general limit equilibrium analysis), but gives little concern to the integration of stream channels which are essential to viable, ecologically stable landforms. Construction is usually conducted following engineering criteria, rather than geomorphological principles. The second approach, termed geomorphic landform design (GLD) seeks to imitate the geomorphology of natural landforms by incorporating their slopes, channels, and drainage patterns. Nicolau (2003) suggested that this method should become more widely accepted as an appropriate means by which to reclaim disturbed landforms.

Toy and Chuse (2005) discuss that geomorphic landform design. Under natural conditions, drainage basins are formed on the land surface to serve as a transportation system for water and sediment. These basins normally exist in an approximate steady-state or dynamic equilibrium state such that geomorphic processes and changes occur slowly. The environment is not degraded by these slow changes. However, disturbances to the steady state can lead to accelerated geomorphic changes as the drainage basins seek to re-establish a similar stable profile as the past, or a new steady-state condition. This process can lead to significant environmental disturbance. Geomorphic landform design seeks to establish a landform that is as close to the steady-state condition as possible which reduces the disturbances to the natural system due to geomorphic processes. A ten-step process for GLD reclamation was given: i) site characterization; ii) reclamation planning and engineering; iii) material management; iv) topographic reconstruction; v) replacement of topsoil or soil substitute; vi) surface manipulation; vii) addition of soil amendments; viii) revegetation; iv) irrigation; and, $\mathrm{x}$ ) site monitoring and maintenance.

With the original geomorphology destroyed by the mining operation, it is impossible to completely restore the landform to existing conditions. However, the reclaimed landform can be established into approximate steady-state condition by replicating the existing basin conditions

(if documented) or those found in nearby undisturbed basins. Toy and Chuse (2005) establishes the four most important drainage-basin characteristics to consider in channel reconstruction: i) drainage-basin relief; ii) drainage-basin area; iii) drainage density; and, iv) drainage pattern. Increasing drainage basin relief, defined as the elevation difference between the watershed boundary and the watershed outlet, resulted in increased runoff, erosion, and sediment yield (sediment discharge per unit area) Increasing the drainage basin area results in an increase in the total stream length, runoff, stream discharge and sediment discharge and a decrease in the sediment yield and sediment delivery ratio (sediment yield/total erosion). Increasing the drainage density (average spacing of channels in drainage area), calculated as the total channel length divided by basin area, increases the mean annual flood magnitude and sediment yield and decreases the average overland-flow length of hillslopes. 
The first step in the design of a geomorphic reclamation is to locate the main channel (Toy and Chuse, 2005). Next, following the drainage networks can be established in a dendritic pattern following the requirements established by the drainage density. Hillslopes and stream channels are then designed by standard practices with hillslopes preferred to take a shape with low gradients, short lengths, and concave profiles.

The Natural Regrade with GeoFluv ${ }^{\mathrm{TM}}$ (Carlson Software, Inc. and Bugosh, 2005) software method was developed by Nicholas Bugosh for a specific approach to geomorphic design. A dendritic drainage pattern and concave longitudinal profiles are used to generate geomorphic landforms. Users are required to input parameters including the drainage density, upland channel reach length, drainage length, elevation of local drainage point, slope of channel at that point, and data on local rainfall and runoff events. After the project boundary is defined and channels are placed to meet the drainage density and length requirements, the program generates a landform fulfilling the basic geomorphic reclamation principles. This design must be iterated in order to fulfill cut/fill volume balance requirements. Additionally, checks on individual slopes and streams must be completed to ensure stability.

A majority of geomorphic reclamation to date, especially applications of GeoFluv ${ }^{\mathrm{TM}}$ have been carried out in the southwestern United States (e.g. Measels and Bugosh, 2007; Bugosh, 2009; Robson et al., 2009). Additional projects have been completed internationally (e.g. MartinDuque et al., 1998; Evans and Willgoose, 2000; Martin-Moreno et al., 2008; Martin-Duque et al., 2010). Studies by Bugosh (2009) and Robson et al (2009) illustrated some of the benefits of geomorphic reclamation. Bugosh (2009), documented minimal erosion and improved water quality as compared to native lands through monitoring of two GLD reclamation sites in New Mexico, USA over 6-7 years. Robson et al. (2009) performed a cost analysis of GLD as compared to conventional reclamation and showed a 44\% savings for GLD through advantages in design, permitting, construction, and maintenance.

Application of geomorphic reclamation approach in Appalachia has only recently begun to be investigated (e.g. Michael et al., 2010; Sears et al., 2013; Russell et al., 2014; Sears et al., 2014). Some of the challenges of implementing the GLD approach in Appalachia were described by Michael et al. (2010). It was suggested that this approach had the potential to be successful in the steep slopes indicative of this region, but several concerns were also documented. These concerns included: i) a lack of support in Federal SMCRA regulations, especially in regards to broad plateaus, curvilinear shapes, and drainage control systems, ii) using the shallow, more stable slopes of GLD in the steep valleys of Appalachia could lead to greater stream disturbance to maintain an equal fill volume, iii) initial high costs of GLD could discourage operator cooperation, iv) complex, time consuming, and expensive earthwork could lead to delays in reclamation completion, v) stability of GLD slopes which blend into the naturally steep (and naturally land-slide prone) slopes of the region may not be assured.

Several geomorphic reclamation studies have been conducted for sites in West Virginia. Sears et al. (2013) was used to generate a large (approximately 100 hectare) design in the southern portion of the state. Carlson's Natural Regrade (2013, Maysville, KY) with GeoFluv ${ }^{\mathrm{TM}}$ with default parameters was used to define six sub-watersheds in the design. Default parameters are based on southwestern United States geomorphology, and were not suggested as appropriate for 
West Virginia. However, the benefits of GLD were illustrated in the design through the protection of $400 \mathrm{~m}$ of the permitted areas streams and generation of almost $10 \mathrm{~km}$ of new stream channels.

Russell et al. (2014) performed a comparative slope stability analysis on the same experimental landform in both conventional and geomorphic layouts. Results from the study gave higher factor of safety values for the geomorphic landform (2.04-3.49) compared to the conventional design (1.25-1.67). The strength increase was attributed to the geomorphic design's shallower slopes and a reduction in pore pressure build-ups. The study also determined that slopes must be analyzed outside of the geomorphic design program as several unstable profiles were generated.

Sears et al. 2014 compared regional geomorphic landform parameters specific to central Appalachia to the default values when applied to large geomorphic designs. Results indicated the importance of obtaining field measured, site specific values for critical geomorphic design criteria such as drainage length and drainage density.

DePriest et al. (2015) completed an analysis of a series of geomorphic designs for a single 10.1 acre valley fill in southern West Virginia using field-measured regional geomorphic properties. The designs confirmed the issues associated with geomorphic reclamation in Appalachia: steep slope topography, stability, and stream recreation. Channel stability, landform stability, and fill volume requirements could not be met without expanding the fill's area of impact beyond the conventional limits and those allowed by current regulations. However, geomorphic designs showed the potential for better habitat, decreased erosion, and improved management of water and groundwater around the fill.

\section{2) Cap and Cover Design}

Guidance for the design of final cover systems is provided by the United States Environmental Protection Agency (2004). Covers are designed to meet erosion, aesthetic, and other requirements to meet their function requirements of containing waste materials and the infiltration of water and air. A cap and cover system is designed to achieve these requirements for time periods of many decades to hundreds of years.

The minimum requirements for closure of Municipal Solid Waste (MSW) landfills are contained in Title 40 of the Code of Federal Regulations, Section 258.60 (40 CFR §258.60). These requirements include: i) "A permeability less than or equal to the permeability of any bottom layer system or natural soils present, or a permeability no greater than $1 \times 10^{-5} \mathrm{~cm} / \mathrm{s}$, whichever is less", ii) use of an infiltration layer at least 18 inches of earthen material, and iii) use of an erosion layer at least 6 inches thick that is capable of sustaining native plant growth. A typical landfill uses six layers to exceed these basic requirements: i) surface layer, ii) protection layer, iii) drainage layer, iv) hydraulic barrier, v) gas collection layer, and vi) foundation layer. Each of these layers fulfills a specific purpose in the design and not all are required in every design (Bonaparte et al., 2004). A typical landfill cover system is illustrated in Figure 2.1. 


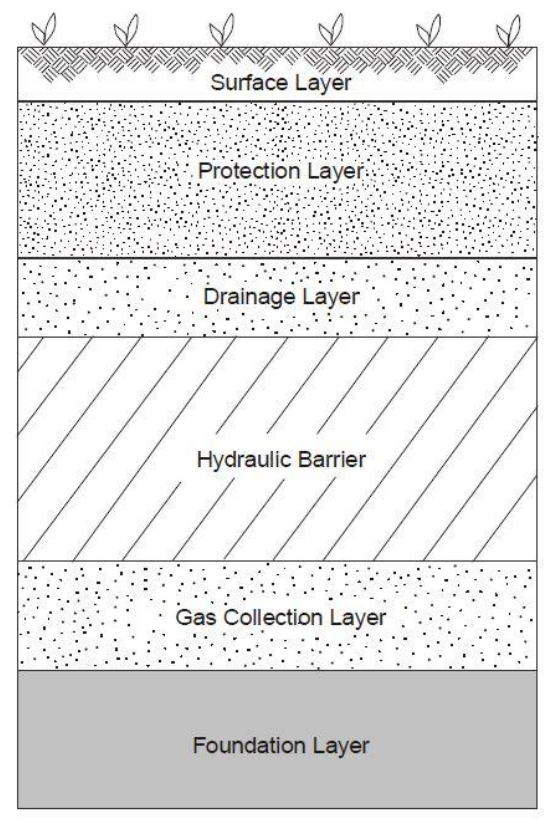

Figure 2.1: Typical landfill cover system (Bonaparte et al., 2004)

\subsection{1) Surface Layer}

Technical guidance for landfill cover design (Bonaparte et al., 2004) states the primary functions of the surface layer are to resist erosion from wind and water and provide a growing medium for vegetation. Slopes for this layer may range from as steep as $2 \mathrm{H}: 1 \mathrm{~V}$ to flatter than $4 \mathrm{H}: 1 \mathrm{~V}$ depending on site requirements. A variety of materials may be used for this layer including topsoil (the most common material), amended topsoil (soils which organic matter, such as fibrous paper waste, or other supplements are added), or other materials such as rock or pavement. The minimum thickness of a surface layer is based on the rooting depth of surface vegetation, anticipated erosion, and construction requirements. The practical minimum of the layer thickness is usually set at $0.15 \mathrm{~m}$ (6 inches). In construction, this layer is only nominally compacted, or not compacted, to allow for plant root development.

\subsection{2) Protection Layer}

The purpose of the protection layer is to protect underlying cover system components and temporarily store water which has passed through the surface layer. It serves as a water reservoir to support plant growth and reduce infiltration to underlying layers. Typically this layer is constructed from on-site or locally available soil. If placed above a drainage layer, filter criteria for the two layers should be met (Bonaparte et al., 2004).

There are several factors which need to be accounted for when setting the minimum thickness of the protection layer. These include: i) frost-penetration depth at the site, ii) need to prevent intrusion by humans, burrowing animals, and roots into underlying layers, iii) depth of plant roots, and iv) temporary storage of rainfall to reduce infiltration to underlying layers and support plant growth in dry periods. Sometimes, the surface layer is combined with the protection layer to form a 'cover layer'. The typical minimum thickness of this combined layer is 0.45 to $0.60 \mathrm{~m}$ 
(18-24 inches). In areas where the hydraulic barrier must be protected by frost, the minimum thickness of the surface growth layer must be greater. This layer is typically compacted with little or no effort such that plant roots can penetrate the soil (Bonaparte et al., 2004).

\subsection{3) Drainage Layer}

The purpose of the drainage layer is to remove water that has permeated the surface and protection layers. It serves to reduce the hydraulic head on the underlying hydraulic barrier and drain the overlying cover layers. This increases the available water-storage capacity which helps to minimize erosion of the surface layers and increase the cover system slope stability by reducing the seepage forces in the surface, protection and drainage layers (Bonaparte et al., 2004).

Granular materials, such as sand or gravel, and geosynthetics (geonets) have been used as material in the drainage layer. The material is required to have an adequate hydraulic conductivity to reduce hydraulic head buildup above the barrier layer and an adequate transmissivity to convey the design flow rate. Filter criteria with adjacent layers must also be met. If a granular soil material is to be used for the drainage layer, the following criteria should be met: i) less than $5 \%$ of material passing No. 200 sieve, ii) maximum particle size of approximately $25-50 \mathrm{~mm}$, iii) limitations on mineralogy (a limit on calcium carbonate is usually applied), iv) minimum acceptable hydraulic conductivity based on site specific requirements. A typical minimum thickness of granular drainage layers is $0.3 \mathrm{~m}$ (12 inches). These layers are typically not compacted and are constructed by loosely end-dumping from a truck and spreading with a low ground pressure bulldozer.

\subsection{4) Hydraulic Barrier}

The hydraulic barrier is designed to limit percolation of water through the cover system to an amount equal to or below the maximum permitted value. Barriers provide high impedance to the flow of water, typically through achieving a very low saturated hydraulic conductivity. A number of materials are typically used in landfill application for the hydraulic barrier. These include geosynthetics such as geomembranes (GMs) or geosynthetic clay liners (GCLs), compacted clay layers (CCLs) or a combination of these materials (Bonaparte et al., 2004).

\section{3) Use of Paper Fiber in modified soils}

Short paper fiber (SPF) is composed of solid residue from the water treatment process at pulp and paper mills. The material is composed of paper making materials including wood fiber, lime, and clay, as well as biologic organisms from water treatment. Historically, the material has been disposed in landfills by paper mills, but recent studies and examples have documented SPF as having benefits as a landfill capping material or soil amendment. Uses have ranged from creation of an impermeable layer from SPF to use in the surface growth layer. In 1992, approximately 7 hectares landfill in New York State, United States, was capped with 20,000 metric tons of SPF material in the frost protection and surface growth layers. Analysis of the site outcomes showed that the synthetic soils had the possibility to perform the same or better than mixed native soils (Laubenstein and Fields, 1994). 
Camberato et al. (2006) summarized a number of agronomic benefits that paper mill sludges offer. These included an increase in soil organic matter and nutrients and soil water holding capacity. Stability benefits were also noted in a decrease in bulk soil density, and reduced soil loss from runoff as a result of increased soil aggregation. Additional liming benefits were noted as paper sludges offered the ability to increase soil $\mathrm{pH}$ substantially.

Maltby (2005) includes a summary of 29 landfill closure projects which have incorporated final cover systems incorporating short paper fiber. Starting dates for these projects ranged from 1990 through the date of publishing (2005). Sizes of the landfills ranged from 1.6 ac to greater than 30 ac Landfill covers ranged in thickness from 18-49 in $(45.7-124.5 \mathrm{~cm})$. The typical placement method for placement of SPF material as a hydraulic barrier was described as toe to crest spreading by a low ground pressure bulldozer. The SPF was rarely compacted after placement. Rather it was leveled with a smooth weighted roller towed behind the bulldozer. Slope Stability failures on slopes below $25 \%$ (4H:1V) were rarely observed, and were typically observed as a slumping during construction due to increase moisture content in the SPF.

The use of short paper fiber in mine reclamation has been documented. Carpenter and Fernandez (2000) evaluated the use of paper mill sludge as a component of manufactured topsoils. Varying amounts of SPF material were added to sand from a gravel mine pit and compared to other soil combinations, including un-amended control topsoil. The study demonstrated that the paper mill sludge created a soil medium effective for vegetative growth. Daniels et al. (2013) performed a study to evaluate the usage of three materials (short paper fiber sludge, fly ash, and lime mud) from the MeadWestVaco (MWV) paper mill in Covington, Virginia. The materials were tested for usage as soil amendments, and specifically for mine reclamation use. Results indicated that the SPF sludge was clearly superior to the other materials and significantly increased plant growth when mixed with mine spoil materials. Additionally, the soils mixed with the highest quantities of SPF sludge were shown to suppress selenium leaching. The Daniels et al. (2013) study suggested that SPF material could be applied to mine reclamation lands at rates of up to 60-75 dry tons per acre as a soil amendment.

Laubenstein (2004) details the benefits of using SPF in the reclamation of coal refuse piles. When applied properly to a coal refuse pile, a mixture of $75 \%$ SPF and $25 \%$ coal refuse can be blended to form a cover achieving hydraulic conductivities of less than or equal to $10^{-7} \mathrm{~cm} / \mathrm{s}-$ even on steeply sloped areas. The refuse pile essentially being cut off from water and air which are two essential ingredients for the generation of acid-mine drainage (AMD). The SPF/coal refuse blend also offers the ability to sustain vegetative growth offering an increase in available water in the soil for plants.

Laubenstein (2004) gave two coal refuse piles at which SPF was used for reclamation purposes. These included the Tygart River coal mining site owned by Peabody Energy in near Fairmont, West Virginia and the Stacks Run refuse pile located in Gladesville, West Virginia. The Tygart River facility used a multilayer cap design which consisted of a $45.7 \mathrm{~cm}$ impermeable layer made of SPF covered by a $45.7 \mathrm{~cm}$ layer of SPF manufactured topsoil. The mine operator was quoted as stating that the company experienced an $80 \%$ reduction in AMD treatment costs after the construction of the cap. The Stacks Run facility showed a significant improvement in water quality after undergoing reclamation with SPF. Water $\mathrm{pH}$ increased from a baseline of 2.8-3 to 
9.0, acidity dropped from $1,100 \mathrm{mg} / \mathrm{L}$ to 0 , aluminum dropped from $58 \mathrm{mg} / \mathrm{L}$ to $<1 \mathrm{mg} / \mathrm{L}$, and manganese dropped from $28 \mathrm{mg} / \mathrm{L}$ to $<1 \mathrm{mg} / \mathrm{L}$. After the observed decrease in pollutant releases, water treatment at the site was allowed to cease. These cases illustrate that there are significant benefits to carrying out reclamation of a coal waste facility using short paper fiber.

\section{4) Coarse Coal Refuse Geotechnical Testing}

There are several sources which document geotechnical testing of coarse coal refuse (CCR). Hegazy et al. (2004) summarized laboratory, insitu strength, and hydraulic conductivity properties for CCR (and fine coal refuse) in England and western Pennsylvania in the United States. First, index properties such as unit weight, specific gravity, and grain size distribution were obtained. The values determined by Hegazy et al. (2004) for these values are summarized in Table 2.1. Total unit weight measurements for this study were taken in the field using a nuclear density gauge, and samples were taken from those locations and laboratory tested for moisture content and subsequently the calculation of dry unit weight. Grain size testing was completed on fresh stockpiles or embankments of coarse coal refuse.

Table 2.1: Index properties for coarse coal refuse from Hegazy et al. (2004)

\begin{tabular}{|l|l|l|l|}
\hline Property & Average & Standard Deviation & $\begin{array}{l}\text { Coefficient of } \\
\text { Variation }\end{array}$ \\
\hline $\begin{array}{l}\text { Total unit weight }(\gamma) \\
\left(\mathrm{kN} / \mathrm{m}^{3}\right)\end{array}$ & 18.5 & 0.89 & 0.048 \\
\hline $\begin{array}{l}\text { Dry Unit weight }\left(\gamma_{\mathrm{d}}\right) \\
\left(\mathrm{kN} / \mathrm{m}^{3}\right)\end{array}$ & 19.7 & 0.93 & 0.047 \\
\hline Specific Gravity $\left(\mathrm{G}_{\mathrm{s}}\right)$ & 2.02 & 0.31 & 0.154 \\
\hline $\begin{array}{l}\text { Moisture Content } \\
(\omega \%)\end{array}$ & $6.4 \%$ & 1.60 & 0.252 \\
\hline $\mathrm{D}_{10}(\mathrm{~mm})$ & $<0.075$ & -- & -- \\
\hline $\mathrm{D}_{30}(\mathrm{~mm})$ & 0.35 & 0.25 & 0.71 \\
\hline $\mathrm{D}_{50}(\mathrm{~mm})$ & 1.23 & 0.62 & 0.50 \\
\hline $\mathrm{D}_{60}(\mathrm{~mm})$ & 2.02 & 0.89 & 0.44 \\
\hline $\begin{array}{l}\text { Passing U.S. \#200 } \\
\text { sieve }(\%)\end{array}$ & $19.76 \%$ & 10.79 & 0.55 \\
\hline
\end{tabular}

Hydraulic conductivity testing results summarized by Hegazy et al. (2004) consisted of falling head and rising head slug tests completed at piezometer locations at CCR disposal sites in western Pennsylvania. These tests yielded an average horizontal hydraulic conductivity value $\left(\mathrm{k}_{\mathrm{h}}\right)$ of $3 \times 10^{-5} \mathrm{~cm} / \mathrm{s}$ with a standard deviation of $2.7 \times 10^{-5} \mathrm{~cm} / \mathrm{s}$ and coefficient of variation of 0.9 .

Hegazy et al. (2004) summarizes strength testing performed on coarse coal refuse material in the laboratory. Tests performed included isotropic consolidated undrained (CU) compression triaxial tests and isotropic consolidated drained (CD) compression triaxial tests. The results of this strength testing is summarized in Table 2.2. 
Table 2.2: Strength properties for coarse coal refuse from Hegazy et al. (2004)

\begin{tabular}{|c|c|c|c|}
\hline Property & Average & Standard deviation & $\begin{array}{c}\text { Coefficient of } \\
\text { variation }\end{array}$ \\
\hline $\begin{array}{c}\text { Effective internal angle } \\
\text { of friction }\left(\phi^{\prime}\right)(\text { degrees) }\end{array}$ & 34 & 3 & 0.09 \\
\hline $\begin{array}{c}\text { Effective cohesion (c') } \\
(\mathrm{kPa})\end{array}$ & 13 & 12 & 0.92 \\
\hline $\begin{array}{c}\text { Effective internal angle } \\
\text { of friction with no } \\
\text { cohesion }\left(\phi^{\prime} \mathrm{c}^{\prime}=0\right) \\
(\text { degrees })\end{array}$ & 37 & 3 & 0.08 \\
\hline
\end{tabular}

The Engineering and Design Manual for Coal Refuse Disposal Facilities (D’Appolonia, 2009) provides a summary of coarse coal refuse properties. Chapter 2 of the manual gives a basic description of coarse coal refuse. The material is described as a well-graded material with particle sizes ranging from fines $(0.074 \mathrm{~mm})$ up to 3 inches $(7.62 \mathrm{~cm})$. The fine percentage is described as ranging from less than $10 \%$ to greater than $20 \%$. Specific gravity values are typically between 1.8 and 2.3. A more detailed description of coarse coal refuse is given in Chapter 6 of the manual, including geotechnical testing results from a variety of sources. Table 2.3 gives a summary of this data which is found in Table 6.3 of the D'Appolonia (2009) design manual.

Table 2.3: Summary of Geotechnical properties from Table 6.3 of D'Appolonia (2009)

\begin{tabular}{|c|c|}
\hline Parameter & $\begin{array}{c}\text { Range of } \\
\text { values }\end{array}$ \\
\hline $\mathrm{D}_{30}(\mathrm{~mm})$ & $0.2-12$ \\
\hline $\mathrm{D}_{50}(\mathrm{~mm})$ & $1-16$ \\
\hline $\mathrm{D}_{60}(\mathrm{~mm})$ & $2.02-22$ \\
\hline Passing U.S. No. 200 sieve $(\%)$ & $1-19.8$ \\
\hline Specific Gravity, $\mathrm{G}_{\mathrm{s}}$ & $1.7-2.6$ \\
\hline $\begin{array}{c}\text { Effective angle of internal friction }\left(\phi^{\prime}\right) \\
\text { (degrees) }\end{array}$ & $27-40$ \\
\hline Effective cohesion (c') (psf) $\{\mathrm{kPa}\}$ & $0-450\{0-21.5\}$ \\
\hline
\end{tabular}

Quaranta and Tolikonda (2011) performed testing on coarse coal refuse, fine coal refuse, and blends of these materials to design non-woven geotextiles for coal refuse filtration. Along with basic index properties, like specific gravity, plasticity index, and grain size distributions, the study also analyzed unit weights and hydraulic conductivities under a range of compaction energies, ranging from a low of $67.84 \mathrm{~kJ} / \mathrm{m}^{3}$ to Standard Proctor $\left(592.5 \mathrm{~kJ} / \mathrm{m}^{3}\right)$ to an over-optimal effort of $636.21 \mathrm{~kJ} / \mathrm{m}^{3}$. A summary of the data from this research is given in Table 2.4. 
Table 2.4: Summary of geotechnical properties from Quaranta and Tolikonda (2011)

\begin{tabular}{|c|c|}
\hline Property & Value \\
\hline Specific Gravity & 2.54 \\
\hline Liquid Limit & $28.4 \%$ \\
\hline Plasticity Index & $7.34 \%$ \\
\hline Dry Unit weight $\left(\gamma_{\mathrm{d}}\right)\left(\mathrm{kN} / \mathrm{m}^{3}\right)$ & $18.22-19.58$ \\
\hline Hydraulic Conductivity, $\mathrm{k}(\mathrm{m} / \mathrm{s})$ & $2.1 \times 10^{-7}-5 \times 10^{-6}$ \\
\hline $\mathrm{D}_{50}(\mathrm{~mm})$ & 2.2 \\
\hline $\mathrm{D}_{15}(\mathrm{~mm})$ & 0.68 \\
\hline $\mathrm{D}_{10}(\mathrm{~mm})$ & 0.53 \\
\hline Soil Coefficient of uniformity $\left(\mathrm{C}_{\mathrm{u}}\right)$ & 5.09 \\
\hline
\end{tabular}

\section{5) Short Paper fiber (paper mill sludge) Geotechnical Testing}

Moo-Young and Zimmie (1996) completed extensive geotechnical testing of paper mill sludges for use in landfill covers. Seven sludges were studied. These included sludge materials from deinking paper mills, blended paper mill community wastewater, integrated paper mills, primary mills, and sludge mined from a landfill representing various ages. Basic index geotechnical tests were performed on the sludges including water content, specific gravity, and Atterberg Limits. It is noted that while the plastic limit for the sludge was easily determined as the sludge behaved similar to clay, difficulties were encountered with the liquid limit test. The material did not regain its initial plasticity after being dried and re-wetted, meaning tests had to be performed from the wet side rather than the dry side. Additionally, fibers in the material caused difficulty in cutting the grooves for satisfactory performance of the liquid limit test. Basic properties from the tests are summarized in Table 2.5.

Table 2.5: Basic Geotechnical properties from Moo-Young and Zimmie (1996)

\begin{tabular}{|c|c|}
\hline Property & Value \\
\hline Water Content (\%) & $150-268$ \\
\hline Specific Gravity & $1.8-2.08$ \\
\hline Plastic Limit (\%) & $94-147$ \\
\hline Liquid Limit (\%) & $218-297$ \\
\hline $\begin{array}{c}\text { Plasticity Index } \\
(\%)\end{array}$ & $77-191$ \\
\hline
\end{tabular}

Moo-Young and Zimmie (1996) explored the relationship between the organics content of paper mill sludge and its corresponding specific gravity. There was a direct relationship observed, with the specific gravity decreasing as the organic content increased. Compaction testing was completed on the paper mill sludges according to ASTM 698-78 (Standard Proctor). Due to high moisture contents, tests were conducted from the wet side. Drying of material was completed via air-drying in open pans and clods of material larger than a \#4 sieve were removed. Optimum dry densities were observed between 5 and $8 \mathrm{kN} / \mathrm{m}^{3}$ at a moisture content between $50 \%$ and $100 \%$. However, at the optimum moisture, it was stated that the material was stiff and unworkable, and that the material had to be at a moisture content of at least $100 \%$ wet of optimum to be a 
desirable landfill capping material. At this point, it can be compacted to low permeabilities and maintain shear strength.

Consolidation and strength testing were also conducted by Moo-Young and Zimmie (1996). The material was found to be very compressible, especially when the material had a high initial moisture content. Strength testing was completed using consolidated undrained (CU) triaxial compression tests. The effective angle of internal friction was observed to vary between 25 and 40 degrees with the effective cohesion ranging between 2.8 and $9.0 \mathrm{kPa}$. It was stated that a large large reduction of the void ratio was observed in the consolidation phase of the triaxial tests. The sludge behavior was described as similar to that of normally consolidated clay.

Permeability testing determined that the hydraulic conductivity was highly dependent on the molded water content. Sludges were observed to see in reduction in hydraulic conductivity of two orders of magnitude as the moisture content was increased from approximately $70 \%$ to 120\% (Moo-Young and Zimmie, 1996).

A summary of compaction, strength, and permeability testing is given in Table 2.6.

Table 2.6: Summary of compaction, strength and permeability results from Moo-Young and Zimmie (1996)

\begin{tabular}{|c|c|}
\hline Property & Value \\
\hline $\begin{array}{c}\text { Dry Unit Weight }\left(\mathrm{kN} / \mathrm{m}^{3}\right) \\
\text { Effective angle of internal friction }\left(\phi^{\prime}\right)\end{array}$ & $25-4$ \\
\hline $\begin{array}{c}\text { (degrees) } \\
\text { Effective cohesion }\left(\mathrm{c}^{\prime}\right)(\mathrm{kPa})\end{array}$ & $2.8-9.0$ \\
\hline Hydraulic Conductivity $(\mathrm{cm} / \mathrm{s})$ & $1 \times 10^{-7}-1 \times 10^{-4}$ \\
\hline
\end{tabular}

\section{6) Slope Stability and Seepage Numerical Modeling}

Numerical modeling was a key tool used in this research. Use of this modeling allowed for the construction of conceptual slopes which could have their geometry, properties, and other features altered. The effects of the alterations were then studied. Through the use of powerful computer modeling software a large number of iterative analyses, which may be time-consuming or even impossible to complete by hand, can be quickly and accurately run.

Multiple analytical procedures can be performed by finite element based software within a single program suite. In this research the SoilVision Systems ${ }^{\mathrm{TM}}$ modeling suite was used. Two modules within the suite, SVSlope ${ }^{\circledR}$ and SVFlux ${ }^{\mathrm{TM}}$ were used for slope stability and seepage modeling, respectively. 


\subsection{1) SVSlope ${ }^{\circledR}$}

SVSlope ${ }^{\circledR}$ is a finite element analysis software used for the analysis of slope stability. The program can be used to model slopes both in two and three dimensions. Fourteen material failure models can be used within SVSlope ${ }^{\circledR}$ including Mohr-Coulomb, Hoek-Brown, and others. The program is also capable of performing fourteen methods of analysis on slope failure surfaces. Some of these methods include Bishop's simplified method of slices, the GLE method, and the Janbu simplified method. Another key feature of SVSlope is the ability to perform coupled steady-state or transient analysis with groundwater and saturation inputs from SVFlux ${ }^{\mathrm{TM}}$. This allows for the effects of the climate on slope stability to be measured.

\section{Mohr-Coulomb failure criterion}

The Mohr-Coulomb failure criterion was used for all materials in this research. Mohr-Coulomb is the most common failure criterion used in geotechnical engineering (Hoek, 2005) and is used widely in the modeling of soils. There are two main parts to the Mohr-Coulomb failure criterion: cohesion and friction with a direct relationship between normal and shear stress. Equation 2.1 defines the Mohr-Coulomb failure envelope .This linear function approximates the shear stress on the failure plane (Das, 2010).

$\tau=c+\sigma \tan \Phi$

Where:

$\tau=$ shear strength

$c=$ cohesion

$\sigma=$ normal stress on the failure plane

$\Phi=$ angle of internal friction

As the cohesion and internal angle of friction values are the most critical input parameters for modeled soils, these values were determined by laboratory testing of the exact materials to be modeled. The laboratory testing is described in detail in Chapter 3.

The General Limit Equilibrium (GLE) analysis method

The General Limit Equilibrium method was used for the slope stability analysis completed in this research. This analysis method is based upon static analysis that can be used to derive the factor of safety are the summation of forces in two direction and the summation of moments about a chosen point of rotation (Fredlund, 1981). The presence of a non-circular slip is often assumed to be due to geological discontinuity within the media (Fredlund, 1981). During the calculation of a non-circular failure the radius of curvature is varying, which results in complex computation which reiterates the benefit of a finite element modeling software.

The GLE method varies from other methods, such as Bishop's simplified method in that interslice shear forces are taken into consideration. The calculations performed to obtain the factor of 
safety with the General Limit Equilibrium method, take into account driving moments and forces; deeming it the preferred method for slope stability analysis. An overview of the calculation method can be seen in Equation 2.2.

$F_{m}=\frac{\Sigma\left[c^{\prime} l+(P-u l) \tan \Phi \prime\right] \mathrm{R}}{\Sigma W_{x}-\Sigma \mathrm{Pf} \pm \mathrm{Aa}}$

Where:

$F_{m}=$ computed factor of safety

$c^{\prime}=$ effective cohesion

$u=$ pore water pressure (if present)

$l=$ length of the failure surface at the base of each slice

$\Phi^{\prime}=$ effective angle of internal friction

$\mathrm{P}=$ the total normal force on the base of a slice

$\mathrm{R}=$ radius of curvature

$W_{x}=$ the total vertical forces due to the mass of a slice of width ' $b$ ' and height ' $h$ '

$A=$ the resultant external water forces

$a=$ the perpendicular distance from the resultant external water forces to the center of rotation

$\mathrm{Pf}=$ resulting moment of failing mass, independent from slice to slice

\subsection{2) SVFlux ${ }^{\mathrm{TM}}$}

SVFlux $^{\mathrm{TM}}$ a finite-element analysis software designed to model groundwater movement and seepage in soils. It is capable of operating in 1,2 , and 3 dimensions and calculating saturated and unsaturated groundwater flow. It features fully automatic mesh generation and refinement. The climatic interface allows for modeling of wet and dry conditions and the effects of features such as evapotranspiration and snow. The program can operate in both steady-state and transient conditions. When coupled with SVSlope ${ }^{\circledR}, S_{\text {SVFlux }}{ }^{\mathrm{TM}}$ allows for the effects of seepage and groundwater movement to be taken into account for slope stability calculations.

\section{7) Conclusion}

The remainder of this report is structured to apply the principles discussed in this chapter to the Royal Scot refuse site. Soil testing was completed on the coarse coal refuse and short paper fiber materials to be used in a multi-layer cap and cover system in the site's geomorphic reclamation plan. Computer modeling will be used to evaluate the stability and effectiveness of the proposed slope profiles. 


\section{3) LABORATORY MATERIAL TESTING}

Geotechnical laboratory testing was completed on two materials to be used in the project in order to obtain their properties. The first material was a crushed shale 'coarse coal refuse' material (referred to in the text as shale) retrieved from the Royal Scot site in Greenbrier County, West Virginia. The second material was a short paper fiber sludge, marketed as MGro ${ }^{\mathrm{TM}}$, obtained from the WestRock paper mill in Covington, Virginia (referred to as MGro ${ }^{\mathrm{TM}}$ in the text). The objective of the testing performed was to quantify the geotechnical properties and gradations of the materials. The results of this laboratory testing will be used in slope stability and ground water flow modeling to create reclamation designs for the property. Determining the geotechnical parameters for each soil, as well as their interface interactions, is essential to understanding the stability of a design to be created from these materials. The test methods used in this research are listed in Table 3.1 and the results are discussed in the following sections. The laboratory tests included duplicate and triplicate specimen testing for precision. Most test data is presented in the appendices.

Table 3.1: Summary of geotechnical tests completed

\begin{tabular}{|l|l|}
\hline \multicolumn{1}{|c|}{ Geotechnical test name } & ASTM standard \\
\hline Moisture Content & D2216-10 \\
\hline $\begin{array}{l}\text { Grain Size Analysis } \\
\text { (Sieve/hydrometer) }\end{array}$ & D422-63 \\
\hline Specific Gravity & D854-10 \\
\hline Atterberg Limits & D4318-10 \\
\hline Standard Proctor Compaction & D698-12 \\
\hline Soil Classification- USCS & D2487-11 \\
\hline Direct Shear & D3080-11 \\
\hline Rigid-Wall Permeability & D5856-95 \\
\hline Flex-wall permeability & D5084-10 \\
\hline Consolidated Undrained Triaxial & D4767-11 \\
\hline
\end{tabular}

\section{1) Coarse Coal Refuse Material Testing}

Shale material samples were collected from the Royal Scot site in the approximate location shown in Figure 3.1. Material was collected from the surface by use of a shovel, placed into buckets and tubs, and returned to the geotechnical laboratory at West Virginia University where it was allowed to dry and acclimate to the laboratory climate. Materials were collected on the dates summarized in Table 3.2. It was attempted to maintain sample consistency by collecting sample in the same location, which was the most easily accessible to collect large sample quantities. However, a GPS was not used to verify the location and some location difference may have occurred. 
Table 3.2: Soil sample collection dates

\begin{tabular}{|c|c|}
\hline \multicolumn{2}{|c|}{ Shale Material Collection dates } \\
\hline Date & Weather conditions \\
\hline $3 / 25 / 2015$ & Cloudy, $\left(4-10^{\circ} \mathrm{C}\right)$ \\
\hline $6 / 10 / 2015$ & Sunny, $\left(21-27^{\circ} \mathrm{C}\right)$ \\
\hline $10 / 8 / 2015$ & Sunny, $\left(21-27^{\circ} \mathrm{C}\right)$ \\
\hline
\end{tabular}

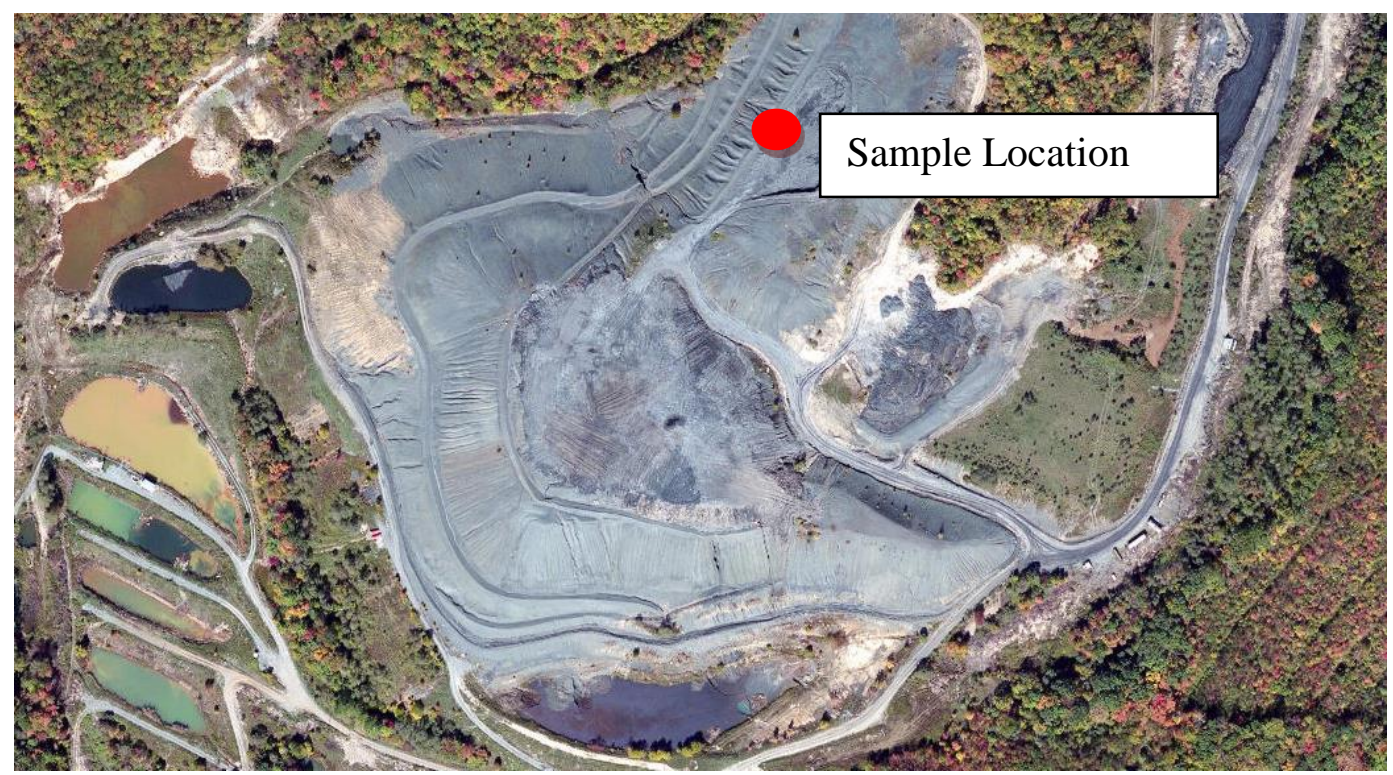

Figure 3.1: Shale Sample location at Royal Scot site (ESRI, 2015)

\subsection{1) Material Description}

The coarse coal refuse collected at the Royal Scot site consisted of a black, crushed shale material. The refuse particles were angular in appearance and a size range from greater than two inches $(50.8 \mathrm{~mm})$ to fines $(>0.074 \mathrm{~mm})$ was observed. Figure 3.2 shows a typical sample of coarse coal refuse from Royal Scot. 


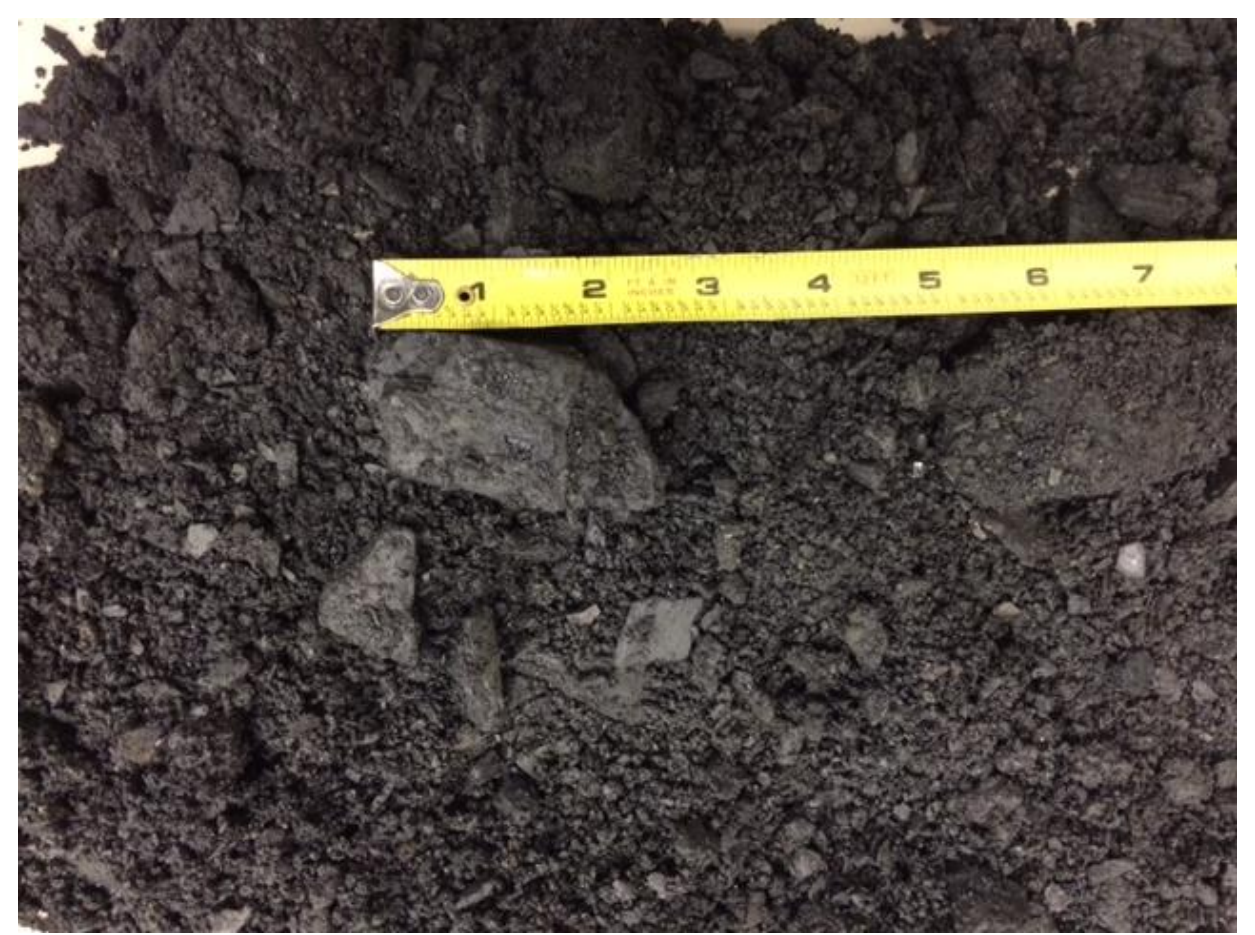

Figure 3.2: Typical coarse coal refuse sample (tape measure in inches)

\subsection{2) Moisture Content}

Testing was performed according to ASTM standard test method D 2216-10- Standard Test Methods for Laboratory Determination of Water Content of Soil and Rock by Mass. Samples were collected under various climatic conditions, but the moisture content was measured in the laboratory after the specimens acclimated to the indoor climate. The average moisture content of the samples was determined to be $6.28 \%$ with a coefficient of variation of 0.033 in the triplicate testing implying little variation.

\subsection{3) Grain Size Distribution}

Grain size distributions were completed for the shale material according to ASTM D422-63. Duplicate testing was completed for the sample on an 'as-received' basis with all particle size gradations included. The objective of this testing was to obtain appropriate data in order to classify the material, and understand its grain size distribution as would be found in the field and how it differs from gradations created for laboratory testing.

There were inconsistencies in the test results mainly due to the presence of a large cobble larger than 2" in the first test and none in the second. This is illustrated in the grain-size distribution curve (Figure 3.3) where the line for test 1 is shown above the line for test 2, especially at large grain sizes.

Hydrometer analysis was completed on fine particles $(<0.074 \mathrm{~mm})$ collected from the shale material according to ASTM D422-63. These particles make up a very small proportion $(<1 \%)$ 
of the overall sample. The hydrometer results were attached to the end of the grain size distribution curve for sample 2. The full hydrometer results are shown given in Appendix A.

After testing, classification of the soil was completed in accordance with the United Soil Classification System (USCS) - ASTM D 2487. The tests indicated a primary soil type on the border of gravel and sand. Averaging the two tests gave a $\mathrm{D}_{50}$ size of $4.33 \mathrm{~mm}$, smaller than the \#4 sieve size (4.76mm) and classifying the soil as a sand. The soil is clean of fines with less than $5 \%$ of the material passing a \#200 sieve. As the coefficient of gradation is less than 1, the sand classifies as poorly graded (SP). A final consideration to be accounted for is the presence of gravel in the sample. Over $15 \%$ of the particles are larger than a \#4 sieve giving the as-received soil a final classification of Poorly Graded Sand with gravel. Test data, including the critical indices, and statistics can be found in Table 3.3 through Table 3.5. The classification and group symbol are given in Table 3.6. The grain size distribution is shown in Figure 3.3.

Table 3.3: Critical Indices for shale as-received GSD

\begin{tabular}{|c|c|c|c|}
\hline \multicolumn{2}{|c|}{ Results } & \\
\hline Critical Indices (mm) & Test 1 & Test 2 & Average \\
\hline $\mathrm{D}_{90}$ & $>50$ & 18 & -- \\
\hline $\mathrm{D}_{60}$ & 8.5 & 5.2 & 6.85 \\
\hline $\mathrm{D}_{50}$ & 5.20 & 3.45 & 4.33 \\
\hline $\mathrm{D}_{30}$ & 1.95 & 1.50 & 1.73 \\
\hline $\mathrm{D}_{25}$ & 1.50 & 1.20 & 1.35 \\
\hline $\mathrm{D}_{10}$ & 0.55 & 0.50 & 0.525 \\
\hline Uniformity Coefficient, $\mathbf{C}_{\mathbf{u}}$ & $\mathbf{1 5 . 4 5}$ & $\mathbf{1 0 . 4 0}$ & $\mathbf{1 2 . 9 3}$ \\
\hline Coefficient of Gradation, $\mathbf{C}_{\boldsymbol{c}}$ & $\mathbf{0 . 8 1}$ & $\mathbf{0 . 8 7}$ & $\mathbf{0 . 8 4}$ \\
\hline
\end{tabular}

Table 3.4: Uniformity Coefficient Statistics

\begin{tabular}{|l|r|}
\hline \multicolumn{2}{|c|}{ Uniformity Coefficient, $\mathbf{C}_{\mathbf{u}}$} \\
\hline Average Uniformity Coefficient & 12.927 \\
\hline Sample Standard Deviation (s) & 3.574 \\
\hline Coefficient of Variation (COV) & 0.276 \\
\hline
\end{tabular}

Table 3.5: Coefficient of Gradation Statistics

\begin{tabular}{|l|l|}
\hline \multicolumn{2}{|c|}{ Coefficient of Gradation, $\mathbf{C}_{\boldsymbol{c}}$} \\
\hline Average Coefficient of Gradation & 0.839 \\
\hline Sample Standard Deviation (s) & 0.037 \\
\hline Coefficient of Variation (COV) & 0.044 \\
\hline
\end{tabular}


Table 3.6: USCS Classification for Shale

\begin{tabular}{|l|c|}
\hline USCS Soil Classification & USCS Symbol \\
\hline $\begin{array}{l}\text { Poorly Graded sand with } \\
\text { gravel }\end{array}$ & SP \\
\hline
\end{tabular}

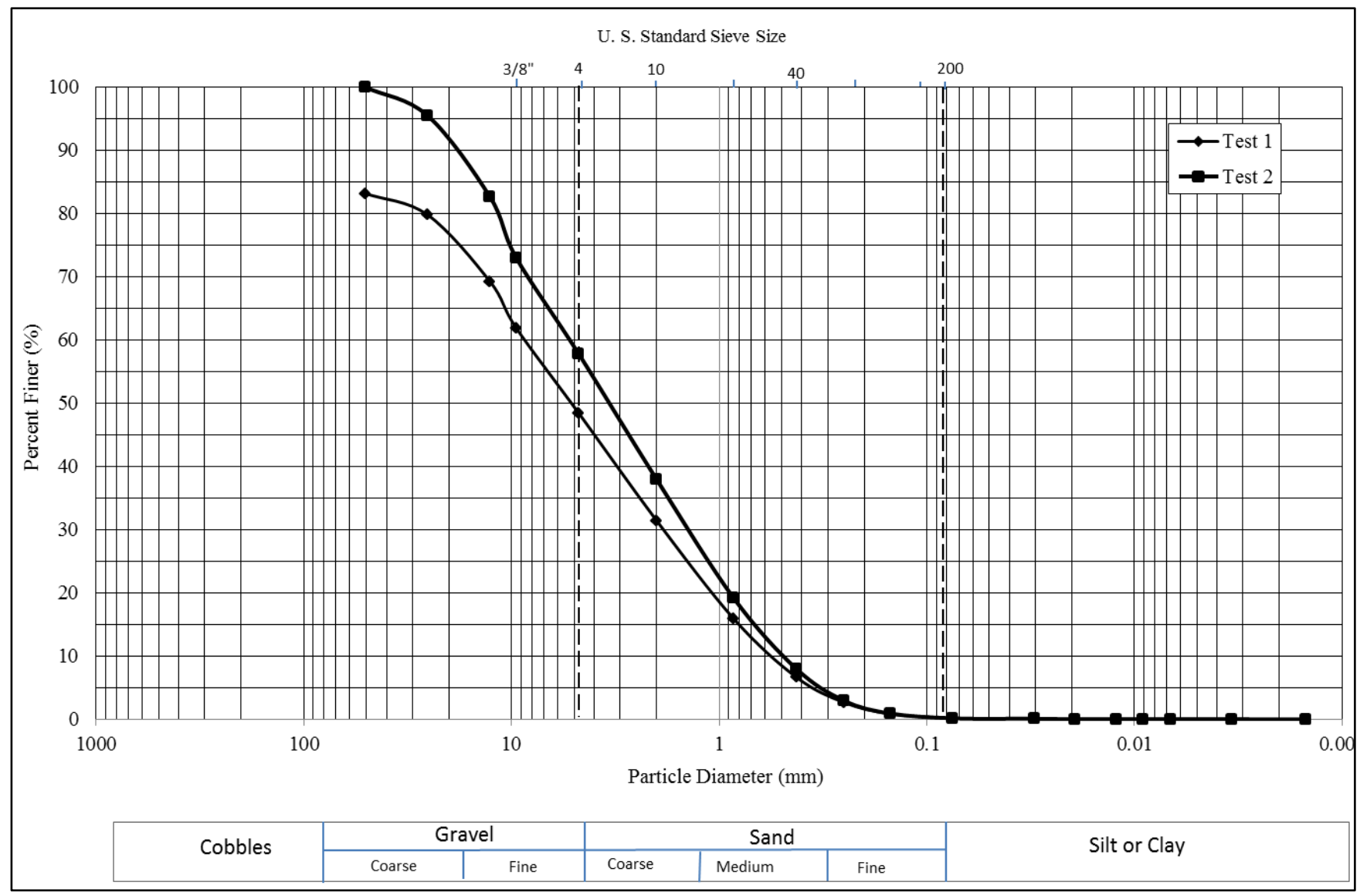

Figure 3.3: Grain-size distribution for shale material

\subsection{4) Specific Gravity}

Specific gravity testing was performed in accordance with ASTM standard test method D-854. One trial, in triplicate, was run for the first sample collected on March 25, 2015. The test results are shown in Table 3.7. Results were very consistent, with a coefficient of variation of 0.015 among the three tests.

Table 3.7: Test Statistics for specific gravity of soil solids

\begin{tabular}{|l|r|}
\hline Average Specific Gravity, $\mathbf{G}_{\mathbf{t}}$ : & $\mathbf{2 . 1 9}$ \\
\hline Sample Standard Deviation for $\mathrm{G}_{\mathrm{t}}(\mathrm{s})$ & 0.033 \\
\hline Coefficient of Variation for $\mathrm{G}_{\mathrm{t}}(\mathrm{COV})$ & 0.015 \\
\hline
\end{tabular}




\subsection{5) Atterberg Limits}

Atterberg limit tests included the plastic limit and liquid limit test. The tests were performed on the shale material according to ASTM standard test method D4318-10: Standard Test Methods for Liquid Limit, Plastic Limit, and Plasticity of soils. A duplicate test was performed in order to ensure accuracy in the data. The objective of the testing was to determine the liquid limit, plastic limit, and plasticity index of the material. The average plastic limit for the tests was found to be 26.1 with a plasticity index of 4 which indicates that the soil is slightly plastic (PL 1-5) (Das, 2010). Results for the Atterberg tests are shown in Table 3.8. The liquid-limit flow curve for the second test is shown in Figure 3.5.

Table 3.8: Determination of plastic limit, liquid limit, and plasticity index

\begin{tabular}{|r|r|r|r|}
\hline & Test 1 & Test 2 & Average \\
\hline Plastic Limit: & 26.6 & 25.6 & 26.1 \\
\hline Liquid Limit: & 30.3 & 29.9 & 30.1 \\
\hline Plasticity Index: & 3.7 & 4.3 & 4.0 \\
\hline
\end{tabular}

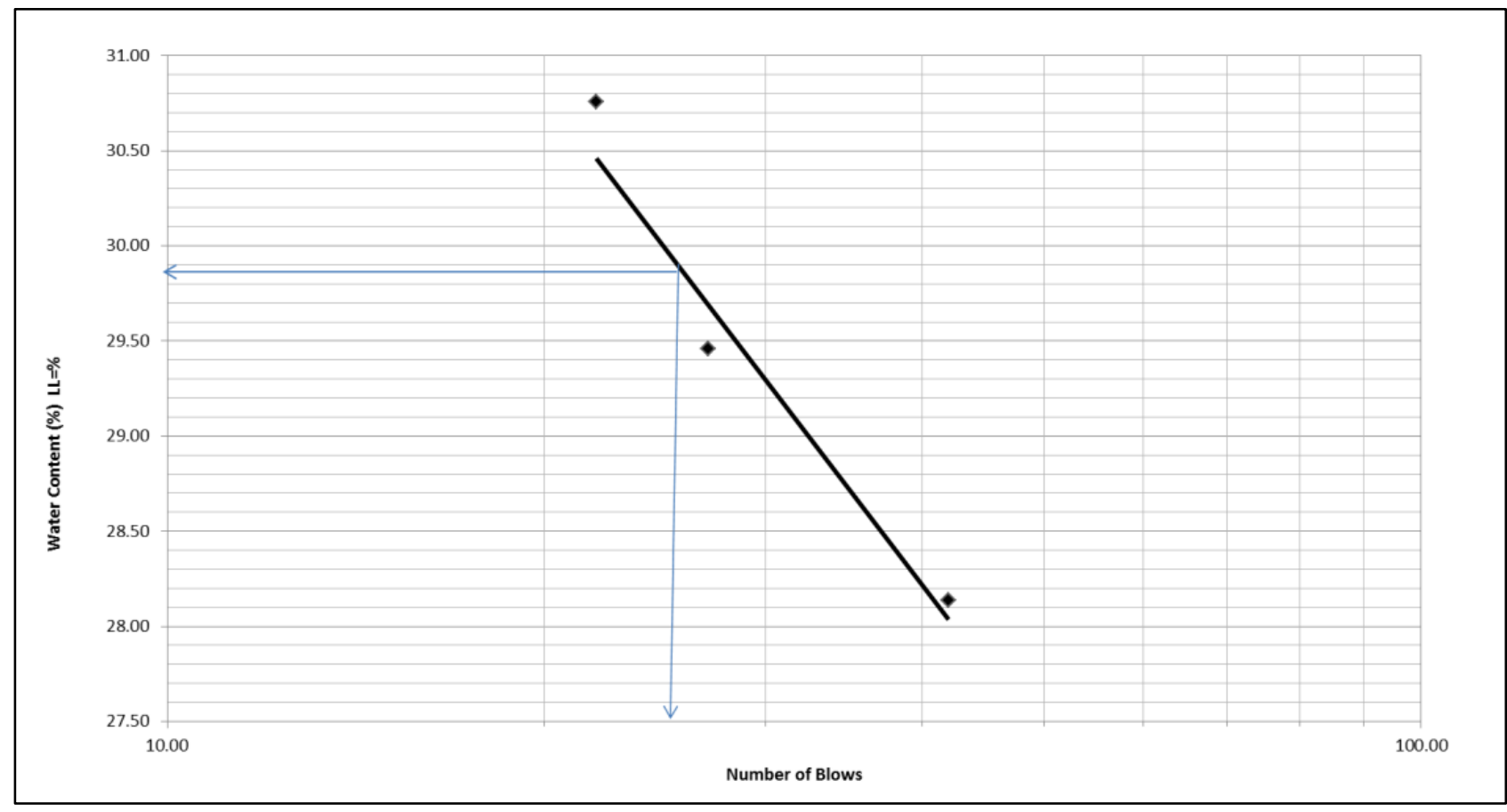

Figure 3.4: Liquid Limit flow curve for test 2 


\subsection{6) Compaction Testing}

Compaction testing was performed according to ASTM D698-12 to find the maximum dry density of the shale material at four predetermined compaction energies. The tests were run at standard proctor compaction effort (energy applied $=592.5 \mathrm{~kJ} / \mathrm{m}^{3}$ ), at a $34 \%$ Proctor effort (energy applied $\left.=203.6 \mathrm{~kJ} / \mathrm{m}^{3}\right)$, and at an $11 \%$ Proctor compaction effort $\left(67.85 \mathrm{~kJ} / \mathrm{m}^{3}\right)$. The tests were also run at double proctor compaction effort (energy applied $=1185.0 \mathrm{~kJ} / \mathrm{m}^{3}$ ) to simulate an over-compacted condition. Multiple water contents were used for the testing for the optimization of each test. The objective of the compaction testing was to find the maximum dry density and corresponding water content of the material at the various compaction energies.

Table 3.9 gives a summary of the maximum dry unit weights and corresponding moisture content values obtained in the testing. A compilation of the compaction curves is given in Figure 3.5. The individual curves and data for each compaction energy tested are given in Appendix A.

Table 3.9: Summary of compaction test results

\begin{tabular}{|c|c|c|}
\hline Compaction Energy & $\begin{array}{c}\text { Optimum dry unit weight } \\
\left(\mathbf{k N} / \mathbf{m}^{\mathbf{3}}\right)\end{array}$ & $\begin{array}{c}\text { Optimum moisture } \\
\text { content }(\boldsymbol{\%})\end{array}$ \\
\hline $67.85 \mathrm{~kJ} / \mathrm{m}^{3}(11 \%$ Proctor $)$ & 14.6 & 17.5 \\
\hline $203.58 \mathrm{~kJ} / \mathrm{m}^{3}(34 \%$ Proctor $)$ & 15.1 & 17.0 \\
\hline $\begin{array}{c}592.5 \mathrm{~kJ} / \mathrm{m}^{3} \text { (Standard } \\
\text { Proctor) }\end{array}$ & 15.9 & 14.3 \\
\hline $1185 \mathrm{~kJ} / \mathrm{m}^{3}$ (200\% Proctor) & 16.0 & 12.3 \\
\hline
\end{tabular}




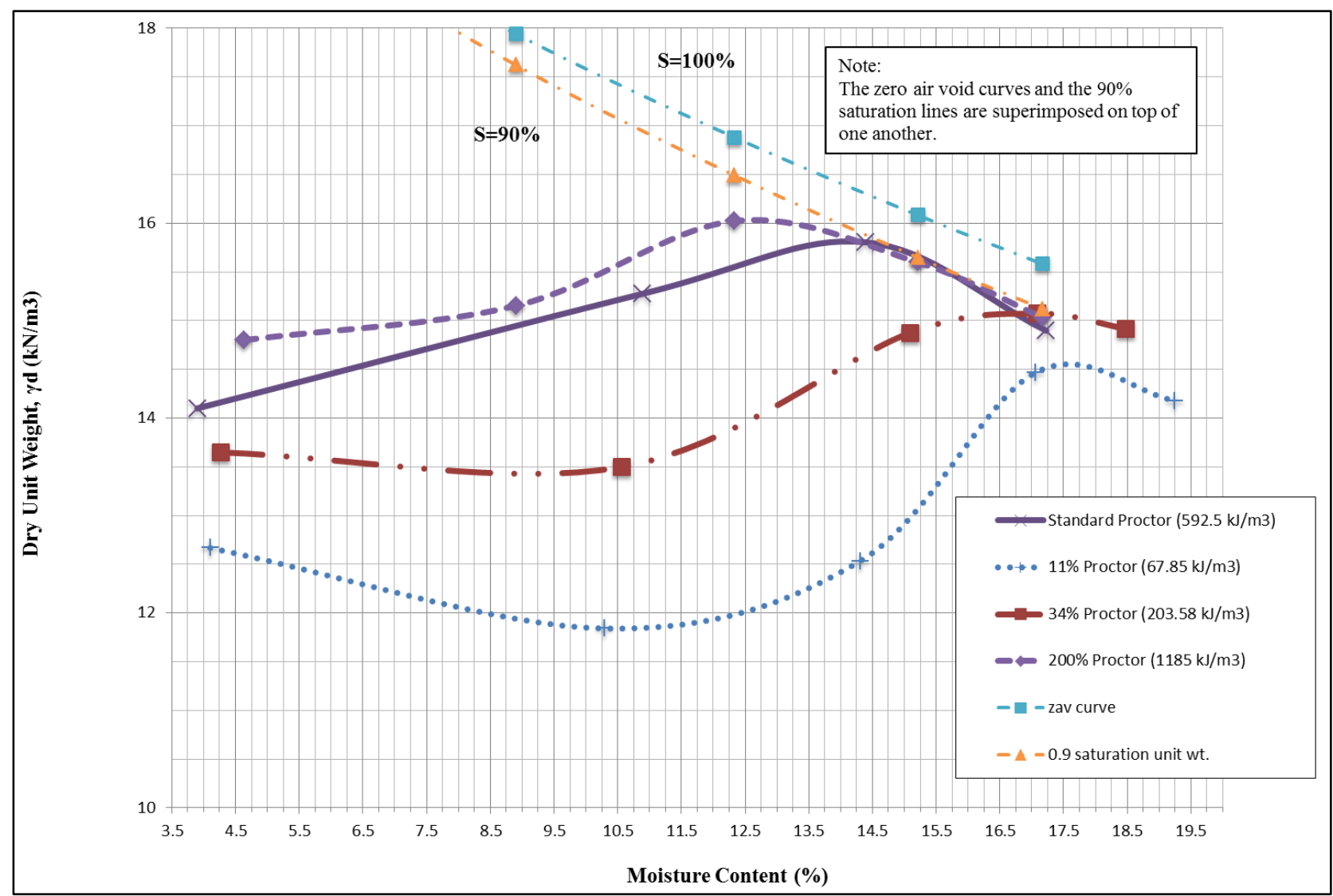

Figure 3.5: Compilation of shale compaction testing results

As the compaction energy was increased, curve shifted up and to the left, achieving a higher dry unit weight at a lower optimum water content, as predicted. This shift ranged from the $11 \%$ proctor energy $\left(67.85 \mathrm{~kJ} / \mathrm{m}^{3}\right)$ test which achieved a maximum dry unit weight of $14.6 \mathrm{kN} / \mathrm{m}^{3}$ at $17.6 \%$ moisture to the over-compaction test $\left(1185 \mathrm{~kJ} / \mathrm{m}^{3}\right)$ which achieved a maximum dry unit weight of $16 \mathrm{kN} / \mathrm{m}^{3}$ at $12.3 \%$ moisture.

\subsection{7) Hydraulic Conductivity testing}

Hydraulic conductivity testing was performed in accordance with ASTM standard test method D5856-95 (Rigid-wall permeability) for specimens compacted to the 11\% Proctor, Standard Proctor, and $200 \%$ Proctor energies. The target compaction density was the maximum dry density of the shale material for each of the test specimens. A hydraulic gradient of $i=5$ was chosen for the first round of testing for all specimens to simulate expected field conditions. This gradient was used for all samples of the $11 \%$ Proctor energy specimens as it yielded test results in an acceptable time. For the second round of testing, the gradient was increased to $i=50$ to accelerate testing times for the second standard compacted sample. Due to difficulties with the $200 \%$ Proctor energy samples using the rigid wall tests, a flex wall testing method (ASTM D5084) was used for these samples. Duplicate testing for each compaction energy was completed to ensure accuracy. Testing was conducted until the specimen achieved steady conditions as indicated by nearly constant hydraulic conductivity readings. Once steady 
conditions were indicated, the hydraulic conductivity was determined as the average of the last five measurements (ASTM D5856).

Standard Proctor Specimens $\left(592.5 \mathrm{~kJ} / \mathrm{m}^{3}\right)$

Two tests were completed on specimens compacted to standard proctor effort $\left(592.5 \mathrm{~kJ} / \mathrm{m}^{3}\right)$. The target dry density was at optimum for the standard proctor compaction effort test data (15.90 $\mathrm{kN} / \mathrm{m}^{3}$ at a water content of $14.3 \%$.). Data for the specimens and the calculated hydraulic conductivities are given in Table 3.10. The average hydraulic conductivity for the specimens compacted to standard proctor energy was calculated to be $2.29 \times 10^{-7} \mathrm{~cm} / \mathrm{s}$.

Table 3.10: Hydraulic Conductivity test results and specimen data for $592.5 \mathrm{~kJ} / \mathrm{m}^{3}$ compacted specimens

\begin{tabular}{|c|c|c|c|c|c|c|c|}
\hline Test & $\begin{array}{c}\text { Water } \\
\text { Content, } \\
\% \mathrm{~W}\end{array}$ & $\begin{array}{c}\text { Dry Unit } \\
\text { Weight of } \\
\text { Compacted } \\
\text { Specimen, } \gamma_{\mathrm{d}} \\
\left(\mathrm{KN} / \mathrm{m}^{3}\right) / \\
\left(\mathrm{lb} / \mathrm{ft}^{3}\right)\end{array}$ & $\begin{array}{c}\text { Degree of } \\
\text { Saturation, } \\
\text { S }\end{array}$ & $\begin{array}{c}\text { Porosity, } \\
\text { n }\end{array}$ & $\begin{array}{l}\text { Saturated } \\
\text { Water } \\
\text { Content, } \\
\mathrm{w}_{\text {sat }}(\%)\end{array}$ & $\begin{array}{c}\text { Hydraulic } \\
\text { Conductivity } \\
\text { (average of last } \\
5 \text { points), } \mathrm{k} \\
(\mathrm{cm} / \mathrm{s})\end{array}$ & $\begin{array}{c}\text { Coefficient of } \\
\text { Variation (last } 5 \\
\text { points of hydraulic } \\
\text { conductivity) }\end{array}$ \\
\hline 1 & 11.86 & $\begin{array}{l}15.57 / \\
99.17\end{array}$ & 0.69 & 0.28 & 17.2 & $1.43 \times 10^{-7}$ & 0.336 \\
\hline 2 & 14.23 & $\begin{array}{l}15.29 / \\
97.39\end{array}$ & 0.78 & 0.29 & 18.35 & $3.15 \times 10^{-7}$ & 0.085 \\
\hline
\end{tabular}

The hydraulic conductivity of the specimens is plotted against pore volume (the porosity multiplied by the total specimen volume) is shown in Figure 3.6. A minimum of 1 pore volume was passed through each specimen. The number of points plotted for test 1 is much higher than test 2 due to the lower gradient used in this test and much longer test time. Additionally, the long test duration was characterized by a very slow flow rate which lead to greater variability in the measurements which can also be observed in Figure 3.6. It appears that both specimens reached stable filter conditions during the test period. 


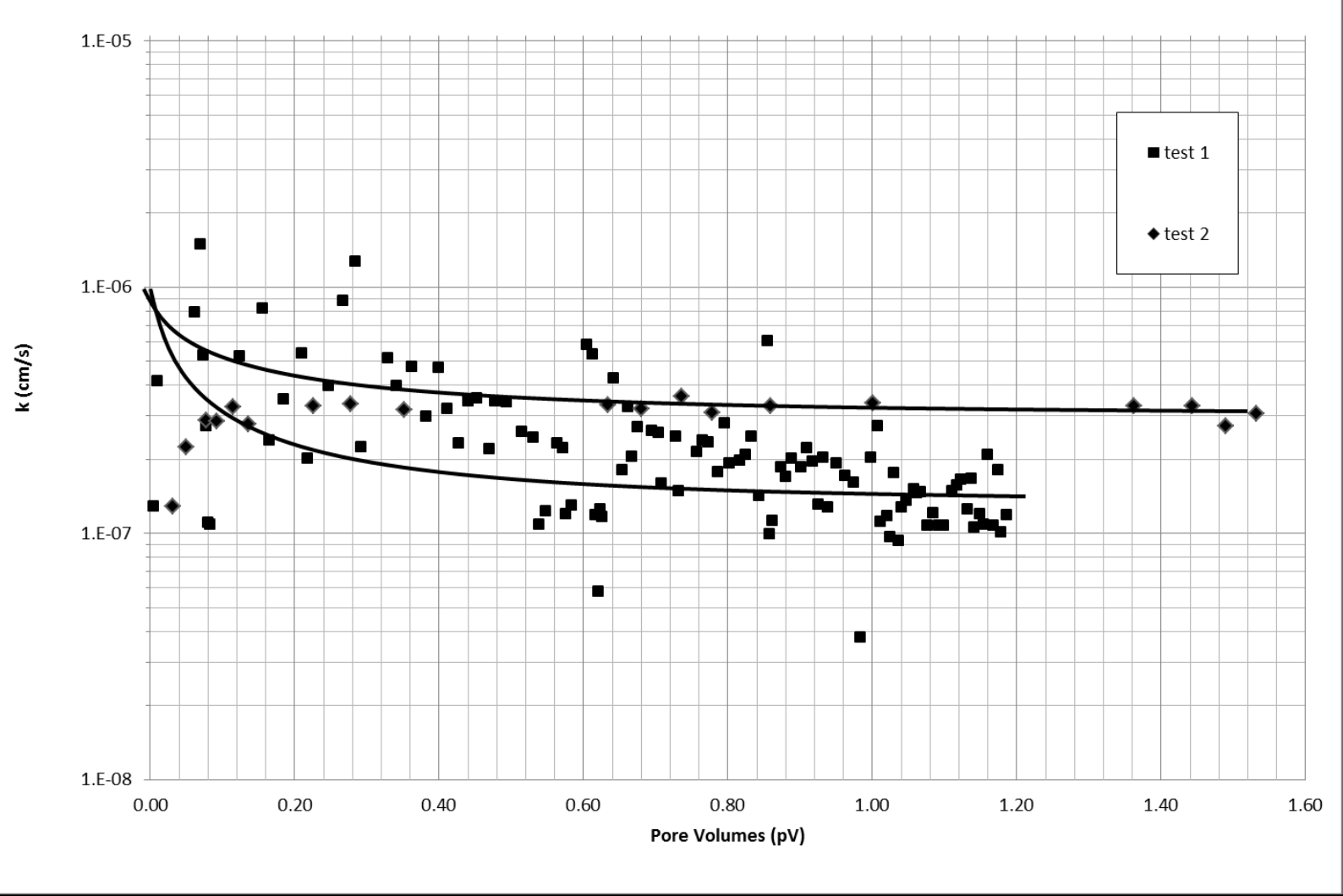

Figure 3.6: Hydraulic conductivity vs. pore volume plot for specimens compacted to Standard Proctor $\left(592.5 \mathrm{~kJ} / \mathrm{m}^{3}\right)$

$11 \%$ Proctor Specimens $\left(67.85 \mathrm{~kJ} / \mathrm{m}^{3}\right)$

Duplicate rigid-wall permeability testing (ASTM D5856-95) was completed on samples compacted to $11 \%$ of standard proctor effort. The purpose of these tests was to determine the hydraulic conductivity of the shale material in a loosely compacted condition. Data for the specimens and the calculated hydraulic conductivity are given in Table 3.11. The average hydraulic conductivity from the two tests was calculated to be $4.22 \times 10^{-4} \mathrm{~cm} / \mathrm{s}$.

Table 3.11: Hydraulic Conductivity test results and specimen data for $67.85 \mathrm{~kJ} / \mathrm{m}^{3}$ compacted specimens

\begin{tabular}{|c|c|c|c|c|c|c|c|}
\hline Test & $\begin{array}{c}\text { Water } \\
\text { Content, } \\
\% \mathrm{~W}\end{array}$ & $\begin{array}{c}\text { Dry Unit } \\
\text { Weight of } \\
\text { Compacted } \\
\text { Specimen, } \gamma_{\mathrm{d}} \\
\left(\mathrm{KN} / \mathrm{m}^{3}\right) / \\
\left(\mathrm{lb} / \mathrm{ft}^{3}\right)\end{array}$ & $\begin{array}{c}\text { Degree of } \\
\text { Saturation, } \\
\text { S }\end{array}$ & $\begin{array}{c}\text { Porosity, } \\
\text { n }\end{array}$ & $\begin{array}{l}\text { Saturated } \\
\text { Water } \\
\text { Content, } \\
\mathrm{w}_{\text {sat }}(\%)\end{array}$ & $\begin{array}{c}\text { Hydraulic } \\
\text { Conductivity } \\
\text { (average of last } \\
5 \text { points), } \mathrm{k} \\
(\mathrm{cm} / \mathrm{s})\end{array}$ & $\begin{array}{c}\text { Coefficient of } \\
\text { Variation (last } 5 \text { points } \\
\text { of hydraulic } \\
\text { conductivity) }\end{array}$ \\
\hline 1 & 15.71 & $\begin{array}{l}11.73 / \\
74.67\end{array}$ & 0.42 & 0.45 & 37.82 & $6.60 \times 10^{-4}$ & 0.187 \\
\hline 2 & 16.71 & $\begin{array}{l}11.81 / \\
75.20\end{array}$ & 0.45 & 0.45 & 37.24 & $1.83 \times 10^{-4}$ & 0.134 \\
\hline
\end{tabular}

The hydraulic conductivity of the specimens is plotted against pore volume (the porosity multiplied by the total specimen volume) is shown in Figure 3.7. A minimum of 3 pore volumes 
were passed through each specimen. Based on the plots it appears that both specimens achieved stable filter conditions.

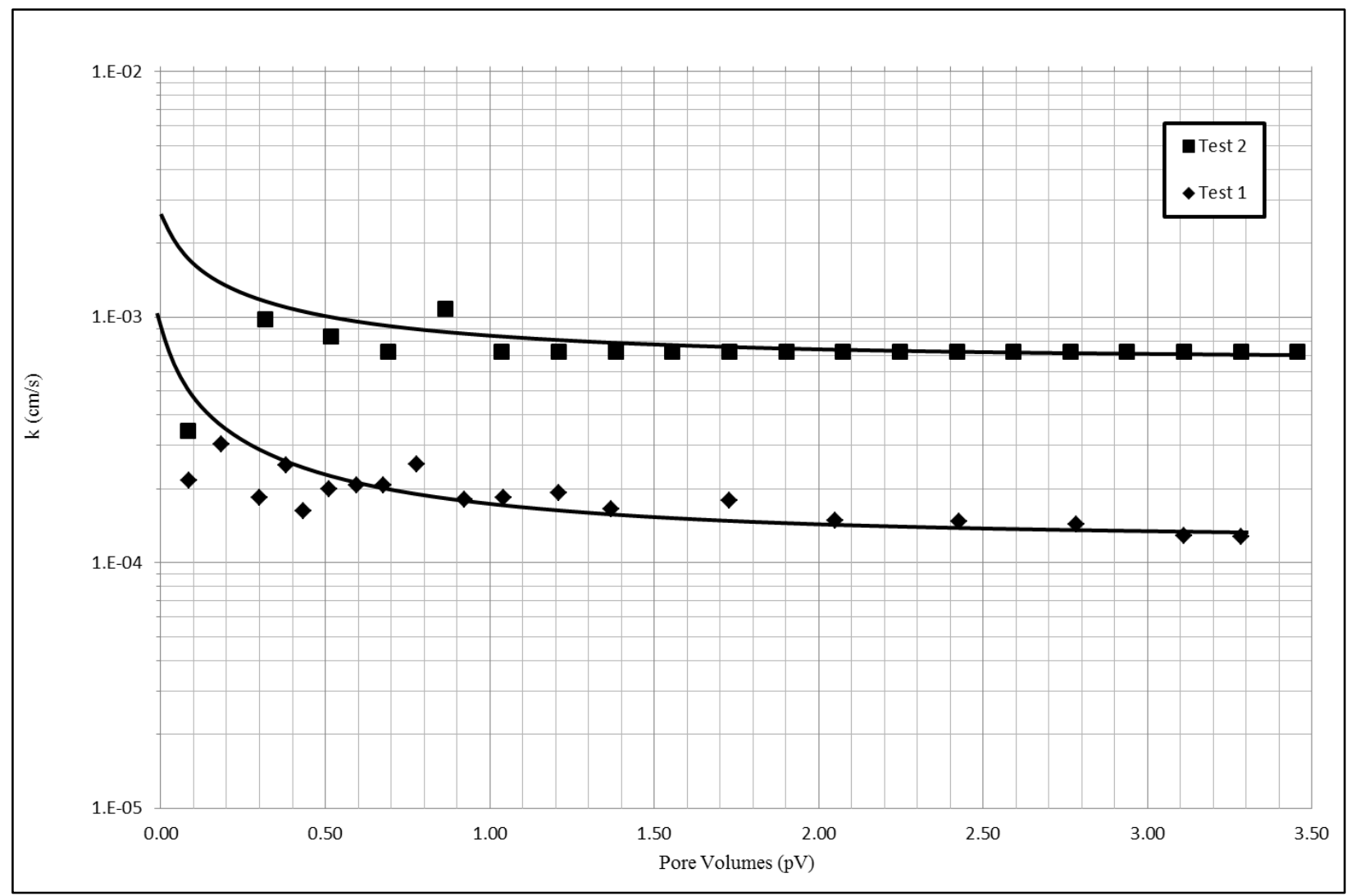

Figure 3.7: Hydraulic conductivity vs. pore volume plot for specimens compacted to 67.85 $\mathrm{kJ} / \mathrm{m}^{3}$

\section{$200 \%$ Proctor Specimens $\left(1185 \mathrm{~kJ} / \mathrm{m}^{3}\right)$}

Rigid wall permeability tests (ASTM D5856-95) were completed for samples compacted to $200 \%$ of standard proctor effort. However, results from this set of tests were plagued by inconsistency. For the first test, the gradient was set to $i=5$. Effluent flow from this test was extremely slow (approximately $1 \mathrm{~mL}$ every 12 hours) which lead to significant variation in calculated hydraulic conductivity from measurement errors and long test times. When the gradient was increased to $i=50$, the calculated hydraulic conductivity was indicated to be two orders of magnitude greater than the first test. This indicated possible sidewall leakage in the sample and inaccurate results.

To combat these problems, the testing method for this set of specimens was changed to a flexwall permeameter (ASTM D5084-10). Duplicate testing was completed for two specimens prepared in a $7.11 \mathrm{~cm}\left(2.8^{\prime \prime}\right)$ diameter split ring mold and compacted to $1185 \mathrm{~kJ} / \mathrm{m}^{3}$. The sample was then cut to a height of approximately $14.2 \mathrm{~cm}(5.6$ ") to achieve a $2: 1$ length to diameter ratio. The flexwall permeability tests were run at a gradient of $i=15$. The specimen data and 
calculated hydraulic conductivity are given in Table 3.12. The average hydraulic conductivity for the two tests was calculated to be $3.50 \times 10^{-7} \mathrm{~cm} / \mathrm{s}$.

Table 3.12: Hydraulic Conductivity test results and specimen data for $1185 \mathrm{~kJ} / \mathrm{m}^{3}$ compacted specimens

\begin{tabular}{|c|c|c|c|c|c|c|c|}
\hline Test & $\begin{array}{c}\text { Water } \\
\text { Content, } \\
\% \mathrm{~W}\end{array}$ & $\begin{array}{c}\text { Dry Unit } \\
\text { Weight of } \\
\text { Compacte } \\
\text { d } \\
\text { Specimen, } \\
\gamma_{\mathrm{d}} \\
\left(\mathrm{KN} / \mathrm{m}^{3}\right) / \\
\left(\mathrm{lb} / \mathrm{ft}^{3}\right)\end{array}$ & $\begin{array}{c}\text { Degree of } \\
\text { Saturation, } \\
\text { S }\end{array}$ & $\begin{array}{c}\text { Porosity, } \\
\text { n }\end{array}$ & $\begin{array}{c}\text { Saturated } \\
\text { Water } \\
\text { Content, } \\
\mathrm{w}_{\text {sat }}(\%)\end{array}$ & $\begin{array}{c}\text { Hydraulic } \\
\text { Conductivity } \\
\text { (average of } \\
\text { last } 5 \text { points), } \\
\mathrm{k}(\mathrm{cm} / \mathrm{s})\end{array}$ & $\begin{array}{l}\text { Coefficient of } \\
\text { Variation (last } \\
5 \text { points of } \\
\text { hydraulic } \\
\text { conductivity) }\end{array}$ \\
\hline 1 & 13.51 & $\begin{array}{l}14.23 / \\
90.63\end{array}$ & 0.28 & 0.72 & 18.79 & $3.51 \times 10^{-7}$ & 0.080 \\
\hline 2 & 13.24 & $\begin{array}{l}14.33 / \\
91.23\end{array}$ & 0.27 & 0.72 & 18.34 & $3.48 \times 10^{-7}$ & 0.047 \\
\hline
\end{tabular}

The unit weights for the specimens compacted to 200\% Proctor Energy were calculated to be lower than those for the standard compacted specimens (approx. $14.2 \mathrm{kN} / \mathrm{m}^{3} \mathrm{vs} .15 .3 \mathrm{kN} / \mathrm{m}^{3}$ ). This is likely due to the fact that specimens for the standard tests were obtained from the first sample taken from the Royal Scot site and the $200 \%$ specimens were derived from the second sample. These samples are believed to be slightly different.

The hydraulic conductivity of the specimens is plotted against pore volume (the porosity multiplied by the total specimen volume) is shown in Figure 3.8. A minimum of approximately 1.5 pore volumes were passed through each specimen. An observation from the testing was that the measured hydraulic conductivity was relatively stable for specimen 2, but started considerably higher for specimen 1 . That specimen's hydraulic conductivity then fell to approximately the same measured value after approximately 1 pore volume of permeant water had passed through. Based on the plots it appears that both specimens achieved stable filter conditions during the test. 


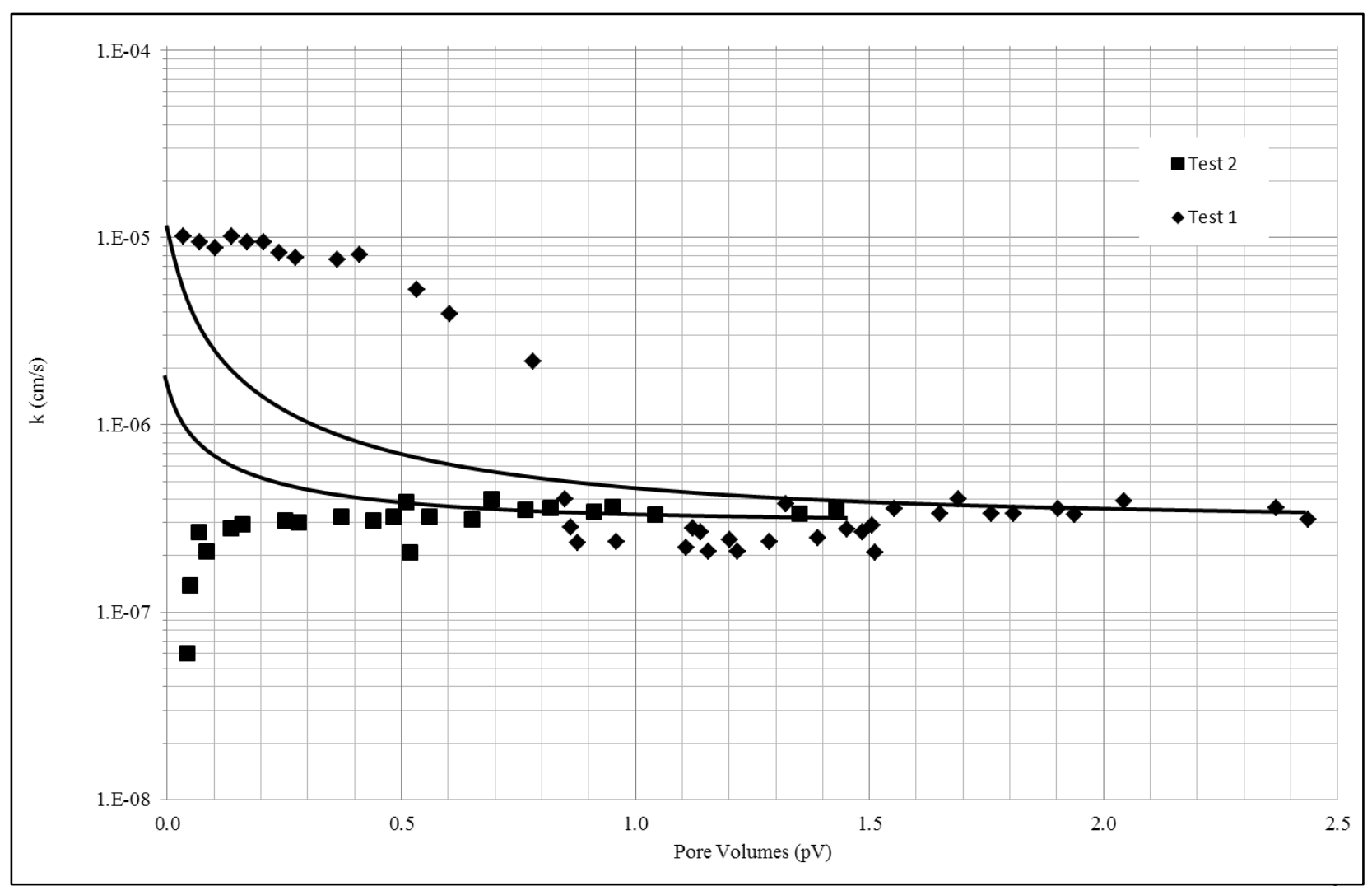

Figure 3.8: Hydraulic conductivity vs. pore volume plot for specimens compacted to $1185 \mathrm{~kJ} / \mathrm{m}^{3}$

Compilation of tests and discussion

Results from hydraulic conductivity testing indicate that the shale material's permeability will reduce by approximately 3 orders of magnitude $\left(10^{-4}-10^{-7} \mathrm{~cm} / \mathrm{s}\right)$ as the compaction energy is increased from $67.85 \mathrm{~kJ} / \mathrm{m}^{3}$ (11\% Proctor) to $592.5 \mathrm{~kJ} / \mathrm{m}^{3}$ (Standard Proctor). Little increase is noted between the standard compaction energy and double standard proctor compaction (1185 $\mathrm{kJ} / \mathrm{m}^{3}$ ). The calculated hydraulic conductivities are summarized in Table 3.13.

Table 3.13: Summary of Hydraulic Conductivity test results

\begin{tabular}{|c|c|}
\hline Compaction Energy & Calculated Hydraulic Conductivity (cm/s) \\
\hline $67.85 \mathrm{~kJ} / \mathrm{m}^{3}(11 \%$ Proctor) & $4.22 \times 10^{-4}$ \\
\hline $592.5 \mathrm{~kJ} / \mathrm{m}^{3}$ (Standard Proctor) & $2.29 \times 10^{-7}$ \\
\hline $1185 \mathrm{~kJ} / \mathrm{m}^{3}(200 \%$ Proctor) & $3.50 \times 10^{-7}$ \\
\hline
\end{tabular}

An additional observation noted during the permeability testing was the acidic nature of the effluent water. The $\mathrm{pH}$ of effluent water was measured occasionally using a digital $\mathrm{pH}$ meter during the testing and the rating was typically between 4 and 5 indicating an acidic solution. This is notable, as distilled water $(\mathrm{pH}=7)$ was used as the influent. A large amount of iron in the effluent was indicated as an orange/red coloration was noted during some of the tests (Figure 3.9). These results were expected, as the shale refuse at the Royal Scot site is currently leading to significant acid mine drainage. 


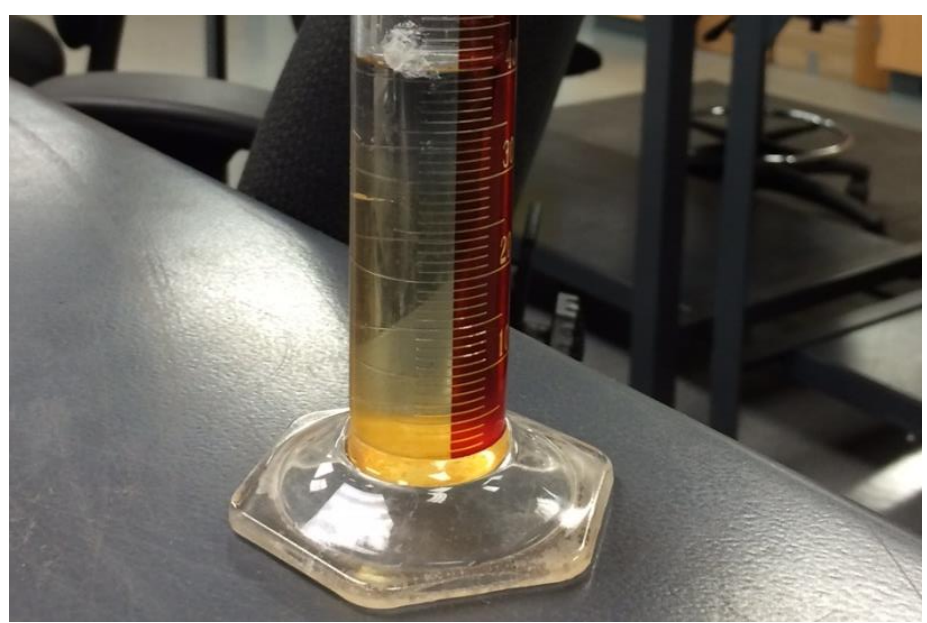

Figure 3.9: Example of acidic effluent observed after hydraulic conductivity testing

\subsection{8) Post-Permeability Grain-Size Distribution}

Following the completion of the rigid-wall permeability testing completed on specimens compacted to standard proctor energy, grain size testing in accordance with ASTM D422-63 was completed on the sample material after the permeability tests. The objective of this testing was twofold. First, it helped to guage whether fines were created during the compaction of the specimen. Second, the tests were used to evaluate if movement of fines particles occurred during the permeability test.

To complete the tests, the specimens were extruded approximately from the rigid-wall permeability mold. The sample was then left to air dry. Once completely dry, it was gently broken apart by hand and then the particle size analysis was completed with sieves. Table 3.14 compares the critical indices and coefficients of the post-permeability sample portions with the as-received sample (each with a $3 / 8$ inch or $9.525 \mathrm{~mm}$ topsize) and Figure 3.10 shows the grain size distributions of these materials. 
Table 3.14: Comparison of grain-size distribution before and after compaction and permeability testing

\begin{tabular}{|c|c|c|c|c|}
\hline \multicolumn{5}{|c|}{ Results } \\
\hline Critcial Indices (mm) & Top & Middle & Bottom & As-received \\
\hline $\mathbf{D}_{\mathbf{9 0}}$ & 6.5 & 7 & 7 & 6 \\
\hline $\mathbf{D}_{\mathbf{6 0}}$ & 2.7 & 2.9 & 2.95 & 2.3 \\
\hline $\mathbf{D}_{\mathbf{5 0}}$ & 2.1 & 2.1 & 2.3 & 1.8 \\
\hline $\mathbf{D}_{\mathbf{3 0}}$ & 1.00 & 1.10 & 1.20 & 0.80 \\
\hline $\mathbf{D}_{\mathbf{2 5}}$ & 0.85 & 0.85 & 0.93 & 0.75 \\
\hline $\mathbf{D}_{\mathbf{1 0}}$ & 0.28 & 0.30 & 0.34 & 0.30 \\
\hline Uniformity Coefficient, $\mathbf{C}_{\mathbf{u}}$ & $\mathbf{9 . 6 4}$ & $\mathbf{9 . 6 7}$ & $\mathbf{8 . 6 8}$ & $\mathbf{7 . 6 7}$ \\
\hline Coefficient of Gradation, $\mathbf{C}_{\mathbf{c}}$ & $\mathbf{1 . 3 2}$ & $\mathbf{1 . 3 9}$ & $\mathbf{1 . 4 4}$ & $\mathbf{0 . 9 3}$ \\
\hline
\end{tabular}

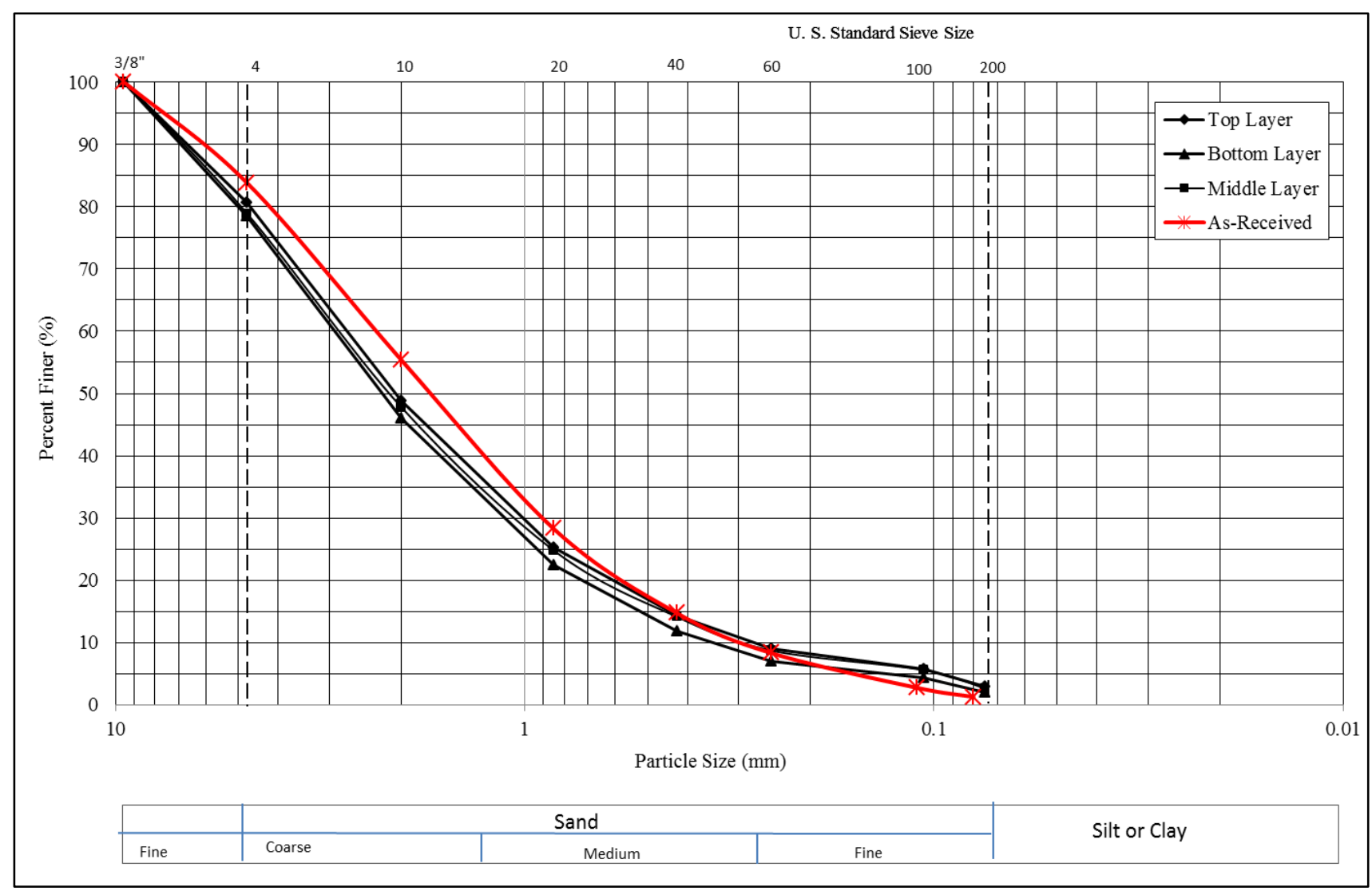

Figure 3.10: Post-permeability grain size distribution for shale standard compacted specimens

Results indicated little increase in the amount of fines within the sample. Only a small increase in material passing a U.S. No. 200 sieve $(0.074 \mathrm{~mm})$ was observed (shown by the postpermeability curves lying above the as-received line at $0.074 \mathrm{~mm}$ ). However, on the whole, the post-permeability specimens appeared slightly coarser than the as-received material. This is likely a result of the particles clumping together after drying and not being fully broken into their 
actual sizes prior to sieving. The observed aggregation implies that some fines were created during the compaction of the specimen.

Little difference was observed between the grain size distribution of the top, middle, and bottom layers of the permeability specimen. This indicates that there was little to no movement of fine particles during the permeability testing.

The possible creation of fines during compaction is a significant finding. These particles would allow for the filling of void spaces and cause the hydraulic conductivity to decrease. This is a likely cause of the calculated hydraulic conductivity being very low for the specimens compacted at the greatest energies.

\subsection{9) Direct Shear Strength testing}

Shear Strength testing was performed on a GeoJac direct shear testing device at a saturated, unconsolidated condition. Specimens were prepared as a standard Proctor compaction sample, $34 \%$ Proctor compaction effort sample, and 11\% Proctor compaction effort sample using the same methods as detailed in Section 3.1.5. The effective angle of internal friction $\left(\phi^{\prime}\right)$ was calculated using Mohr-Coulomb failure criterion concepts. The tests were performed on the shale material passing a \#4 sieve $(4.97 \mathrm{~mm})$ size to determine the shear strength properties of the material under specified normal stress conditions. The stress conditions were determined by multiplying an assumed soil density by the depth of the fill on a sample slope cross-section at the Royal Scot site in Greenbrier County, WV. This testing was designed to obtain soil strength properties at various locations throughout the fill slope in order to evaluate potential failures at each of these locations.

\section{Testing Conditions}

Four distinct conditions were selected for shear strength testing. These conditions were chosen from four conceivable slope failure locations: a base failure at the interface between the shale fill and existing soil, a failure in the middle of the fill, a failure consisting of approximately one bench, and a shallow surface failure. Figure 3.11 shows a possible cross section of the slope and Table 3.15 summarizes the conditions used for testing. For each case, a soil density of (100 $\mathrm{lb} / \mathrm{ft}^{3}$ ) was used to estimate the normal stress condition. This density serves as an average of the material at various compaction energies as would likely be found in the field condition. 


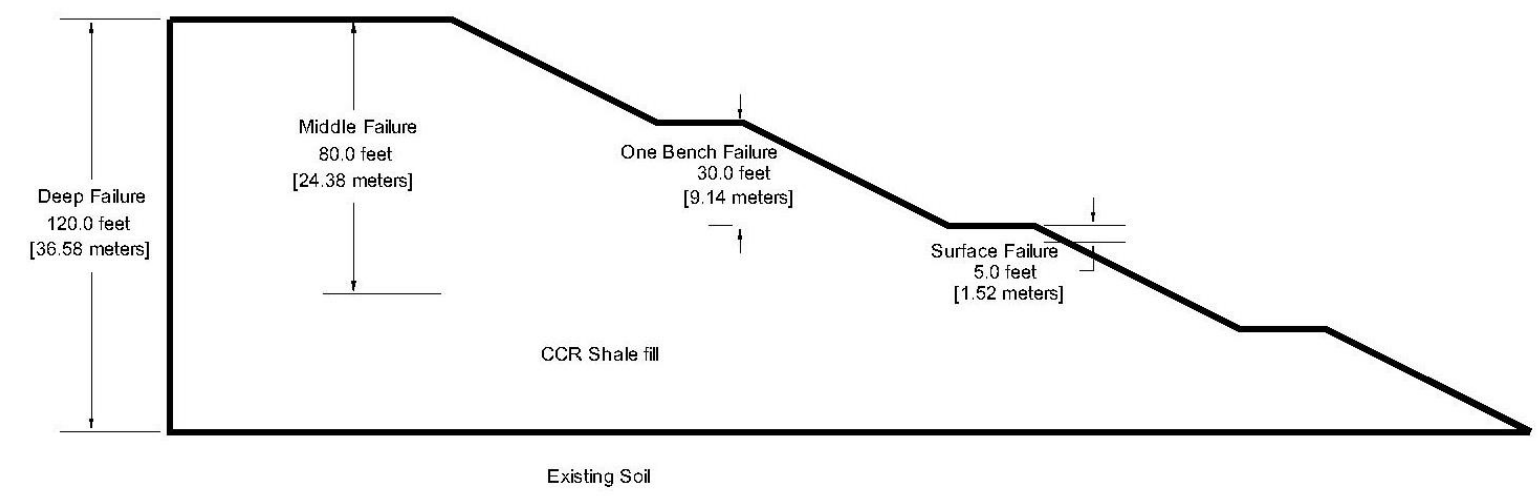

Figure 3.11: Representative Royal Scot slope cross-section

Table 3.15: Testing conditions for Direct Shear tests

\begin{tabular}{|c|c|c|}
\hline Failure type & Depth, $\mathbf{m}(\mathbf{f t})$. & Normal force, $\mathbf{~ k P a}\left(\mathbf{l b} / \mathbf{f t}^{2}\right)$ \\
\hline Deep (foundation) & $36.58(120)$ & $575(12,000)$ \\
\hline Middle & $24.38(80)$ & $383(8,000)$ \\
\hline One bench & $9.14(30)$ & $144(3,000)$ \\
\hline Surface & $1.52(5)$ & $24(500)$ \\
\hline
\end{tabular}

Samples compacted to Standard Proctor Energy $\left(592.5 \mathrm{~kJ} / \mathrm{m}^{3}\right)$

A standard proctor compaction specimen was prepared and layer depths were each approximately $1 / 3$ the height of the compaction mold. After compaction was completed the specimen was extruded approximately one third at a time. The center of each layer was captured in a direct shear ring mold. Direct shear tests were performed on each ring specimen. No standing time between soil mixing and specimen creation was necessary as specified in ASTM D3080 for well graded sand. The soil's granular nature and small percentage of fines indicate that any consolidation that would occur would be minimal and occur quickly. As such, 5-minute time steps were used for initial consolidation prior to shearing. At least triplicate testing was completed at each loading condition.

The sample was compacted in a standard 4" diameter Proctor mold using the same procedures as described in section 3.1.5. The target moisture content and density were the optimum values from section $3.1 .5\left(14.3 \%, 15.9 \mathrm{kN} / \mathrm{m}^{3}\right)$. The average properties for the compaction molds are given in Table 3.16 . 
Table 3.16: Average properties of compaction molds used for direct shear specimens compacted to $592.5 \mathrm{~kJ} / \mathrm{m}^{3}$

\begin{tabular}{|c|c|c|c|}
\hline \multicolumn{2}{|c|}{ Water Content, w\% } & \multicolumn{2}{c|}{ Dry Unit Weight $\left(\mathbf{K N} / \mathbf{m}^{3}\right), \gamma_{\mathbf{d}}$} \\
\hline $\begin{array}{c}\text { Average, } \\
\bar{x}\end{array}$ & Standard Deviation, s & Average, & Standard Deviation, $\mathrm{s}$ \\
\hline 12.99 & & $\bar{x}$ & \\
\hline
\end{tabular}

The samples used for direct shear testing were mostly dry of the optimum value and their dry unit weights were calculated to be significantly lower than the target optimum value. This is a result of the material in this test being derived from the second sample of shale obtained from the Royal Scot site. This sample consistently yielded lower unit weights when compared to the first sample for the other rounds of direct shear testing.

Following the completion of testing at all for loading conditions, the results were combined to calculate the overall angle of internal friction. This angle was calculated on two conditions. First, the angle was calculated simply based on the linear best fit line accounting for some cohesion and calculating this value. For a second result, the y-intercept of the best fit line was set to 0 in order to simulate a zero-cohesion condition. Results for both calculations were similar with the best fit line yielding $\phi=41.4^{\circ}$ and cohesion ( $\mathrm{c}^{\prime}$ ) of $25.6 \mathrm{kPa}$ and the zero-cohesion condition yielding $\phi_{c^{\prime}=0}=43.2^{\circ}$. The shear stress vs. normal stress plot can be seen in Figure 3.12. The complete results for each test specimen can be found in Appendix A.

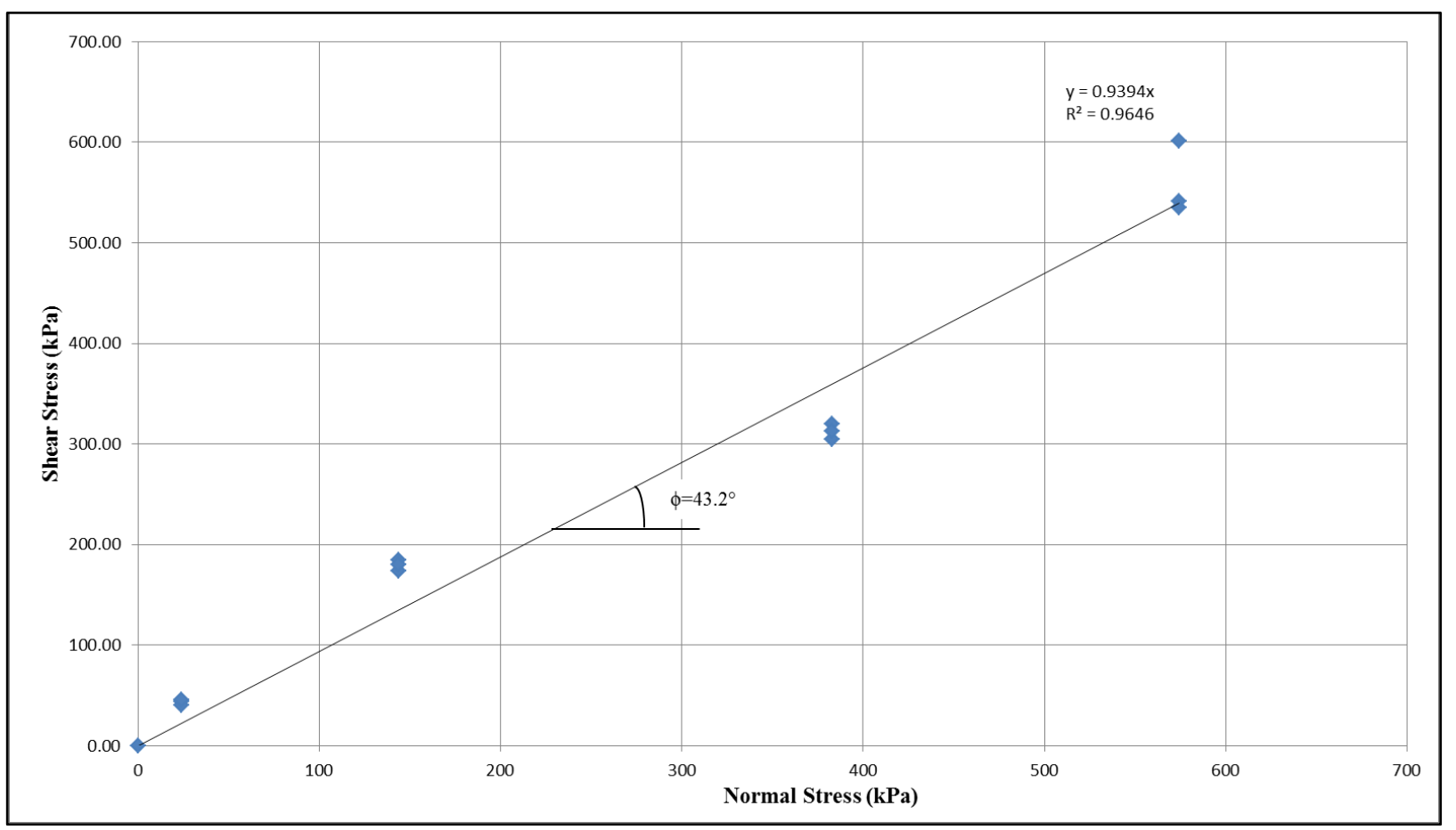

Figure 3.12: Combined shear stress vs. normal stress plots for all specimens compacted to $592.5 \mathrm{~kJ} / \mathrm{m}^{3}$ (Standard Proctor)

A majority of the data points at each normal stress tested were very consistent, as demonstrated by the small coefficient of variation values shown in Table 3.17. 
Table 3.17: Summary of Direct Shear results at each normal stress test point

\begin{tabular}{|c|c|c|c|}
\hline Test Condition & $\begin{array}{c}\text { Average maximum } \\
\text { shear stress }\end{array}$ & Standard deviation & $\begin{array}{c}\text { Coefficient of } \\
\text { variation }\end{array}$ \\
\hline Deep $(575 \mathrm{kPa})$ & 559.30 & 36.74 & 0.0657 \\
\hline Medium $(383 \mathrm{kPa})$ & 312.46 & 7.59 & 0.0243 \\
\hline Low $(144 \mathrm{kPa})$ & 179.43 & 5.17 & 0.0290 \\
\hline Surface $(24 \mathrm{kPa})$ & 43.08 & 2.61 & 0.0610 \\
\hline
\end{tabular}

Samples compacted to $34 \%$ Proctor $\left(203.58 \mathrm{~kJ} / \mathrm{m}^{3}\right)$

No information on the insitu density of the shale fill at the Royal Scot site was available. To more accurately model slope stability, the strength of the material was tested at various compaction energies and four point tests were completed at the same normal forces as used for the standard compacted specimens (575 kPa, $383 \mathrm{kPa}, 144 \mathrm{kPa}$, and $24 \mathrm{kPa})$.

Direct-shear specimens were extruded from standard 4" Proctor compaction molds as specified in section 3.1.5.2. The target moisture content and dry density were the optimum values determined in the compaction testing $\left(17.0 \%, 15.1 \mathrm{kN} / \mathrm{m}^{3}\right)$. The average moisture and unit weight statistics for the compaction molds is given in Table 3.18. The obtained moisture contents were relatively close to the target, but again the dry unit weigh was calculated to be well below the targeted optimum. As with the standard compaction specimens, this was believed to be a result of the second shale sample being used in the tests.

Table 3.18: Average properties of compaction molds used for direct shear specimens compacted to $34 \%$ Proctor

\begin{tabular}{|c|c|c|c|}
\hline \multicolumn{2}{|c|}{ Water Content, w\% } & \multicolumn{2}{c|}{ Dry Unit Weight $\left(\mathbf{K N} / \mathbf{m}^{\mathbf{3}}\right), \boldsymbol{\gamma}_{\mathbf{d}}$} \\
\hline $\begin{array}{c}\text { Average, } \\
\bar{x}\end{array}$ & Standard Deviation, $\mathrm{s}$ & $\begin{array}{c}\text { Average, } \\
\bar{x}\end{array}$ & Standard Deviation, $\mathrm{s}$ \\
\hline 16.66 & 1.56 & 13.15 & 0.20 \\
\hline
\end{tabular}

Following the completion of the tests under each specific loading condition, the results were combined to determine an aggregate result. As these calculations incorporate each of the tests, they are the most likely to achieve an accurate and representative result. The aggregated results are given in Appendix A.

Calculations for the combined tests were completed on two bases. First, the points were plotted on a normal stress vs. shear stress graph and a linear best fit line was applied to the data. The slope was then used to calculate the internal angle of friction and the $y$-intercept gives the cohesion value. This method yields an effective internal angle of friction $\phi=42.48^{\circ}$ and cohesion $\mathrm{c}^{\prime}=21.54 \mathrm{kPa}$.

Second, the data was plotted and again a linear best fit line applied, but this time the line's intercept was set to the origin $(0 \mathrm{kPa}, 0 \mathrm{kPa})$ to simulate a zero-cohesion situation. Results from 
this analysis yielded an internal angle of friction $\phi=43.96^{\circ}$. The results from this method are shown in Figure 3.13.

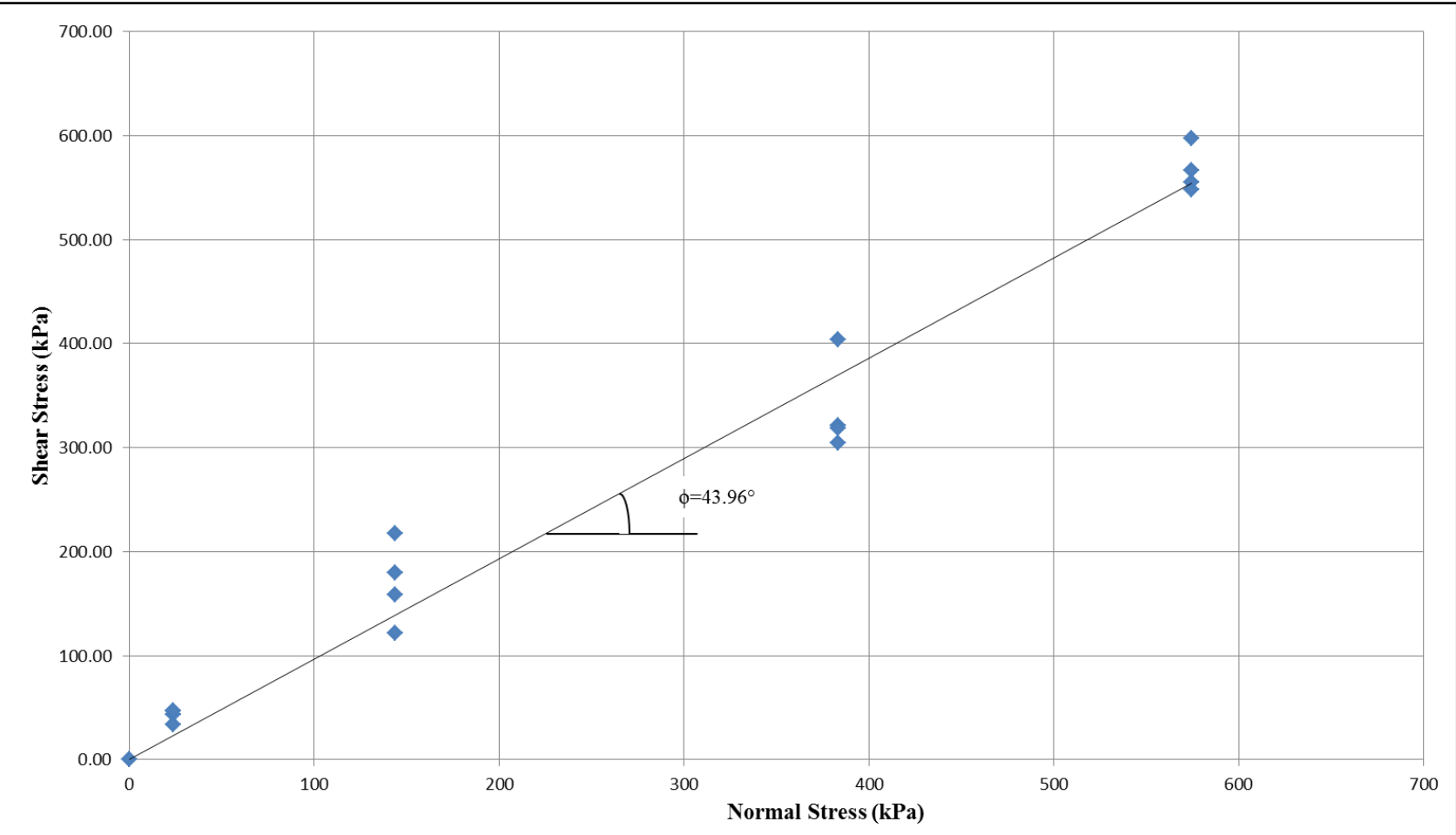

Figure 3.13: Combined shear stress vs. normal stress plots for all specimens compacted to $203.6 \mathrm{~kJ} / \mathrm{m}^{3}$ (34\% Proctor)

Results for the specimens compacted to 34\% Proctor energy were not as consistent as those for the standard proctor compacted specimens as indicated by the larger spread of data points at each normal stress condition and the coefficient of variation values in Table 3.19. The coefficient of variation values are approximately one order of magnitude greater for the 34\% Proctor energy test indicating greater uncertainty in those test results.

Table 3.19: Statistics for Direct Shear tests of specimens compacted to 34\% Proctor energy

\begin{tabular}{|c|c|c|c|}
\hline Test Condition & $\begin{array}{c}\text { Average maximum } \\
\text { shear stress }\end{array}$ & Standard deviation & $\begin{array}{c}\text { Coefficient of } \\
\text { variation }\end{array}$ \\
\hline Deep $(575 \mathrm{kPa})$ & 567.09 & 21.68 & 0.038 \\
\hline Medium $(383 \mathrm{kPa})$ & 337.12 & 45.04 & 0.134 \\
\hline Low $(144 \mathrm{kPa})$ & 163.30 & 37.36 & 0.229 \\
\hline Surface $(24 \mathrm{kPa})$ & 40.01 & 6.41 & 0.160 \\
\hline
\end{tabular}

Samples compacted to $11 \%$ Proctor $\left(67.85 \mathrm{~kJ} / \mathrm{m}^{3}\right)$

Shale coarse coal refuse specimens were tested at a compaction of $11 \%$ of Standard Proctor effort in order to simulate the loosely compacted material within the fill structure. This test is 
believed to represent a majority of fill volume found at shallow depths at the Royal Scot site. The same test procedure and normal stress loadings were used for this set of tests at the other compaction energies.

Direct-shear specimens were extruded from standard 4" Proctor compaction molds as specified in section 3.1.5.3. The target moisture content and dry density were the optimum values determined in the compaction testing $\left(17.5 \%, 14.6 \mathrm{kN} / \mathrm{m}^{3}\right)$. The average moisture and unit weight statistics for the compaction molds is given in Table 3.20. The obtained moisture contents and dry unit weights were calculated to be below the targeted optimum. As with the direct shear specimens at different compaction energies, the dry unit weight difference was believed to be a result of the second shale sample being used in the tests.

Table 3.20: Average properties of compaction molds used for direct shear specimens compacted to $11 \%$ Proctor

\begin{tabular}{|c|c|c|c|}
\hline \multicolumn{2}{|c|}{ Water Content, w\% } & \multicolumn{2}{c|}{ Dry Unit Weight $\left(\mathbf{K N} / \mathbf{m}^{\mathbf{3}}\right), \boldsymbol{\gamma}_{\mathbf{d}}$} \\
\hline $\begin{array}{c}\text { Average, } \\
\bar{x}\end{array}$ & Standard Deviation, $\mathrm{s}$ & $\begin{array}{c}\text { Average, } \\
\bar{x}\end{array}$ & Standard Deviation, $\mathrm{s}$ \\
\hline 16.36 & 0.99 & 12.10 & 0.30 \\
\hline
\end{tabular}

Following the completion of testing at all for loading conditions, the results were combined to calculate the overall angle of internal friction. This angle was calculated on two conditions. First, the angle was calculated simply based on the linear best fit line accounting for some cohesion and calculating this value. For a second result, the y-intercept of the best fit line was set to 0 in order to simulate a zero-cohesion condition. Results for both calculations were similar with the best fit line yielding $\phi=43.83^{\circ}$ and cohesion (c') of $14.46 \mathrm{kPa}$ and the zero-cohesion condition yielding $\phi_{c^{\prime}=0}=44.96^{\circ}$. The compiled results are given in Appendix A. Figure 3.14 shows the shear stress vs. normal stress plot with the best fit line not accounting for cohesion. 


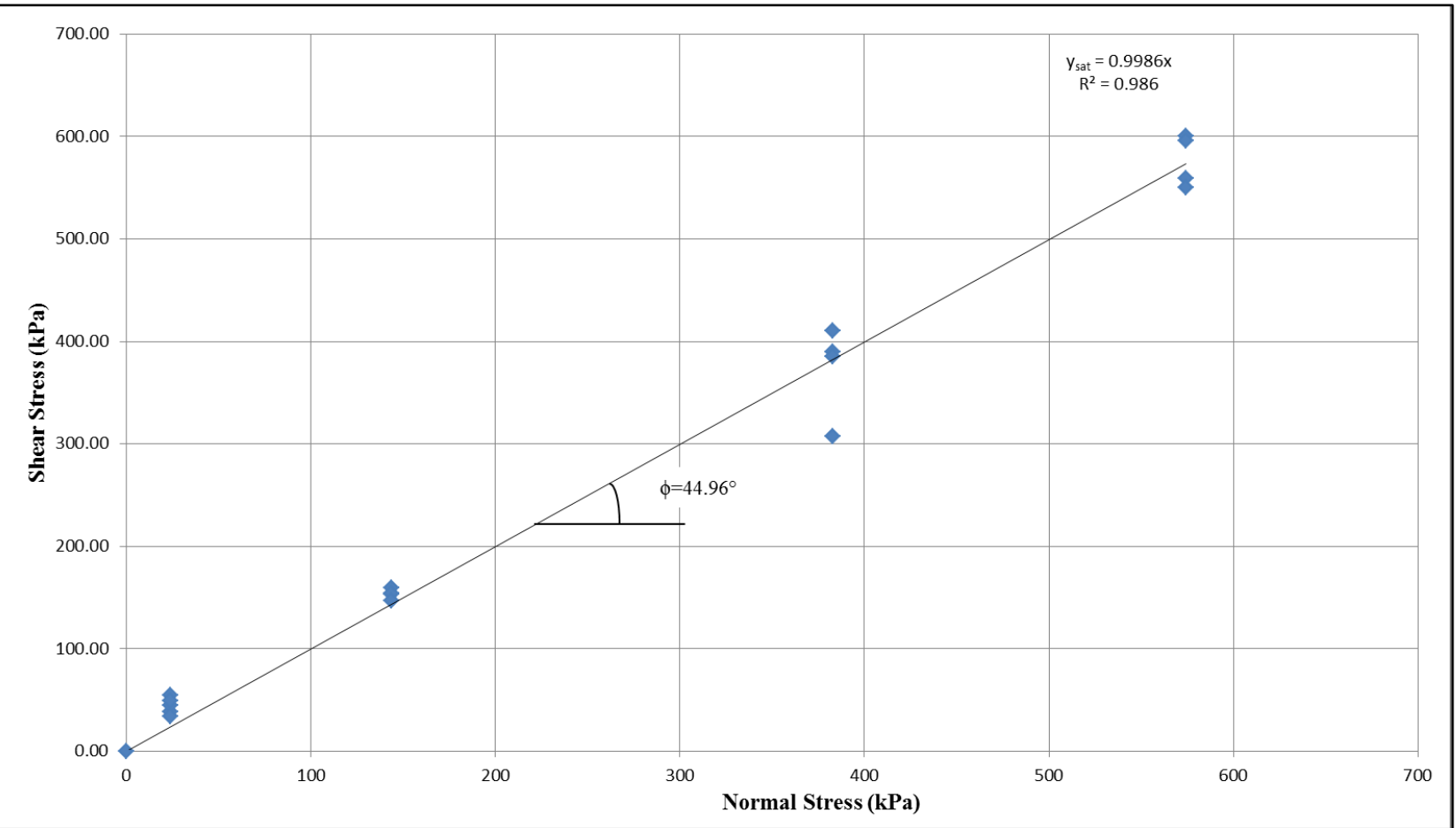

Figure 3.14: Combined shear stress vs. normal stress plots for specimens compacted to 67.85 $\mathrm{kJ} / \mathrm{m}^{3}$ (11\% Proctor)

Some variation among the tests was observed at each normal stress condition tested as indicated by the spread of data points and the coefficient of variation values given in Table 3.21. The variation is similar to that observed in the tests on the specimens compacted to $34 \%$ Proctor energy.

Table 3.21: Direct shear test statistics for specimens compacted to 11\% Proctor energy

\begin{tabular}{|c|c|c|c|}
\hline Test Condition & $\begin{array}{c}\text { Average maximum } \\
\text { shear stress }\end{array}$ & Standard deviation & $\begin{array}{c}\text { Coefficient of } \\
\text { variation }\end{array}$ \\
\hline Deep $(575 \mathrm{kPa})$ & 576.34 & 25.50 & 0.044 \\
\hline Medium $(383 \mathrm{kPa})$ & 373.39 & 45.46 & 0.122 \\
\hline Low $(144 \mathrm{kPa})$ & 140.16 & 14.79 & 0.106 \\
\hline Surface $(24 \mathrm{kPa})$ & 44.12 & 8.04 & 0.182 \\
\hline
\end{tabular}

Comparison of test sample results

Testing was completed at four normal stress conditions for three samples of the shale material compacted at different energies. The results for the tests are shown in Table 3.22. 
Table 3.22: Summary of all direct shear test results (all stresses effective)

\begin{tabular}{|c|c|c|c|}
\hline Test Sample & $\begin{array}{c}\phi_{\text {best fit }} \\
\text { (degrees) }\end{array}$ & $\begin{array}{c}\mathbf{C} \\
(\mathbf{k P a})\end{array}$ & $\begin{array}{c}\boldsymbol{\phi}_{\mathbf{c}=\mathbf{0}} \\
(\mathbf{d e g r e e s})\end{array}$ \\
\hline Shale (standard compaction) & 41.40 & 25.60 & 43.21 \\
\hline Shale (34\% standard compaction) & 42.48 & 21.54 & 43.96 \\
\hline Shale (11\% standard compaction) & 43.83 & 16.99 & 44.96 \\
\hline
\end{tabular}

Results for the friction angle from each of the three samples were very consistent. Overall, the friction angle ranged between 41 and 44 degrees when apparent cohesion was accounted for and 43 and 45 degrees with zero cohesion.

Overall, effective angle of friction increases as the compaction energy decreases and the effective cohesion increases as more compaction energy is applied. This is theorized to be the result of particle crushing and the creation of fines that occurs at higher compaction energies. This phenomena was indicated in the post-permeability grain testing completed in section 3.1.7, and is further indicated by the increase in effective cohesion observed in the tests on specimens compacted to standard proctor energy.

Analysis of the shear stress vs. shear strain curves for the tests yielded an additional finding. A larger percentage difference in the shale's peak strength against its residual strength was seen in specimens tested at the surface normal stress condition ( $24 \mathrm{kPa}$ ) compared to the deep condition $(575 \mathrm{kPa})$. The shear stress vs. shear strain plots for the $34 \%$ Proctor compacted specimens at the deep condition (Figure 3.15) and the surface loading (Figure 3.16) illustrate this phenomenon. The remaining stress-strain curves for each direct shear loading condition can be found in Appendix A. 


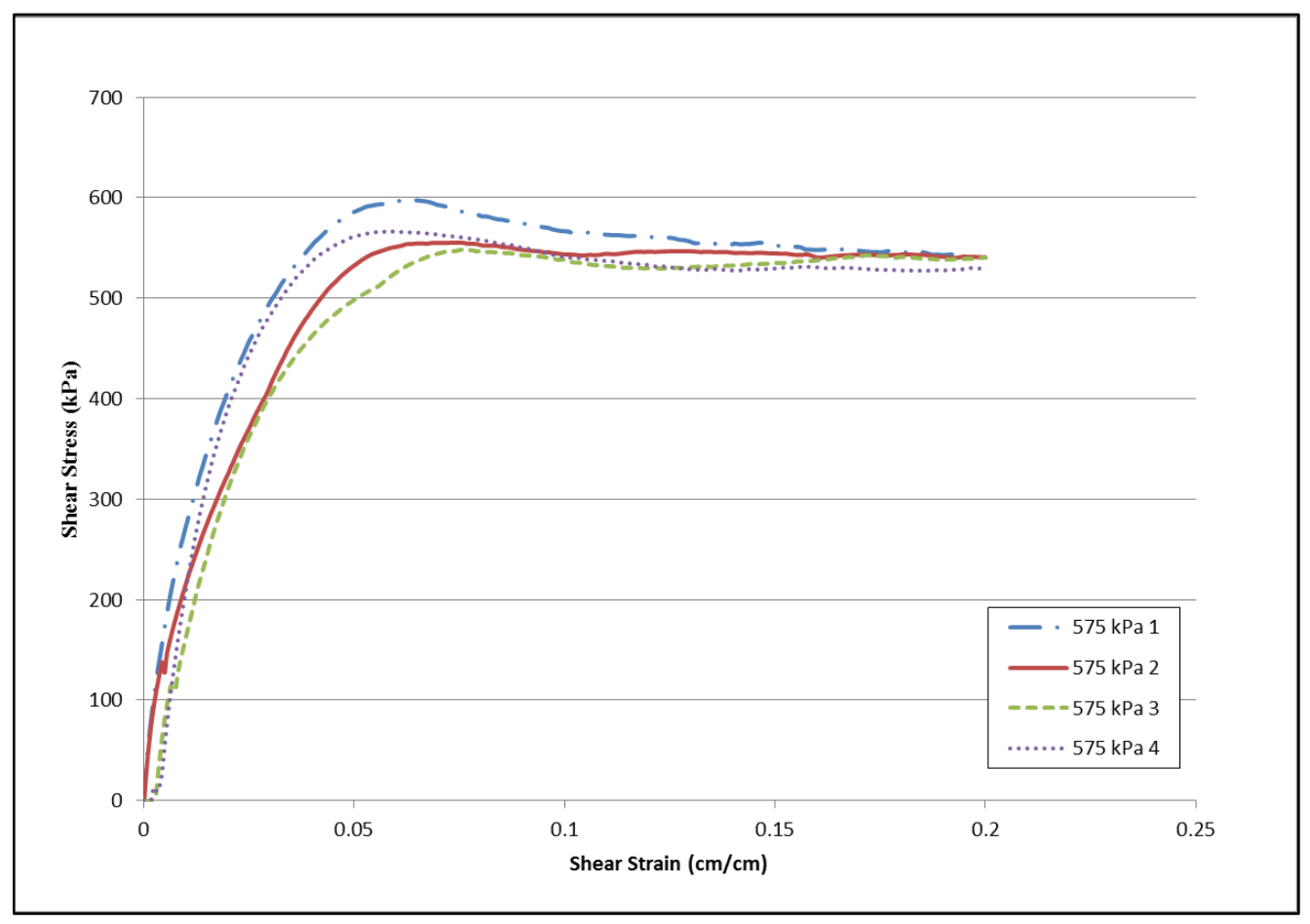

Figure 3.15: Shear Stress vs. shear strain plot for shale direct shear specimens compacted to $34 \%$ of standard proctor energy under deep loading condition.

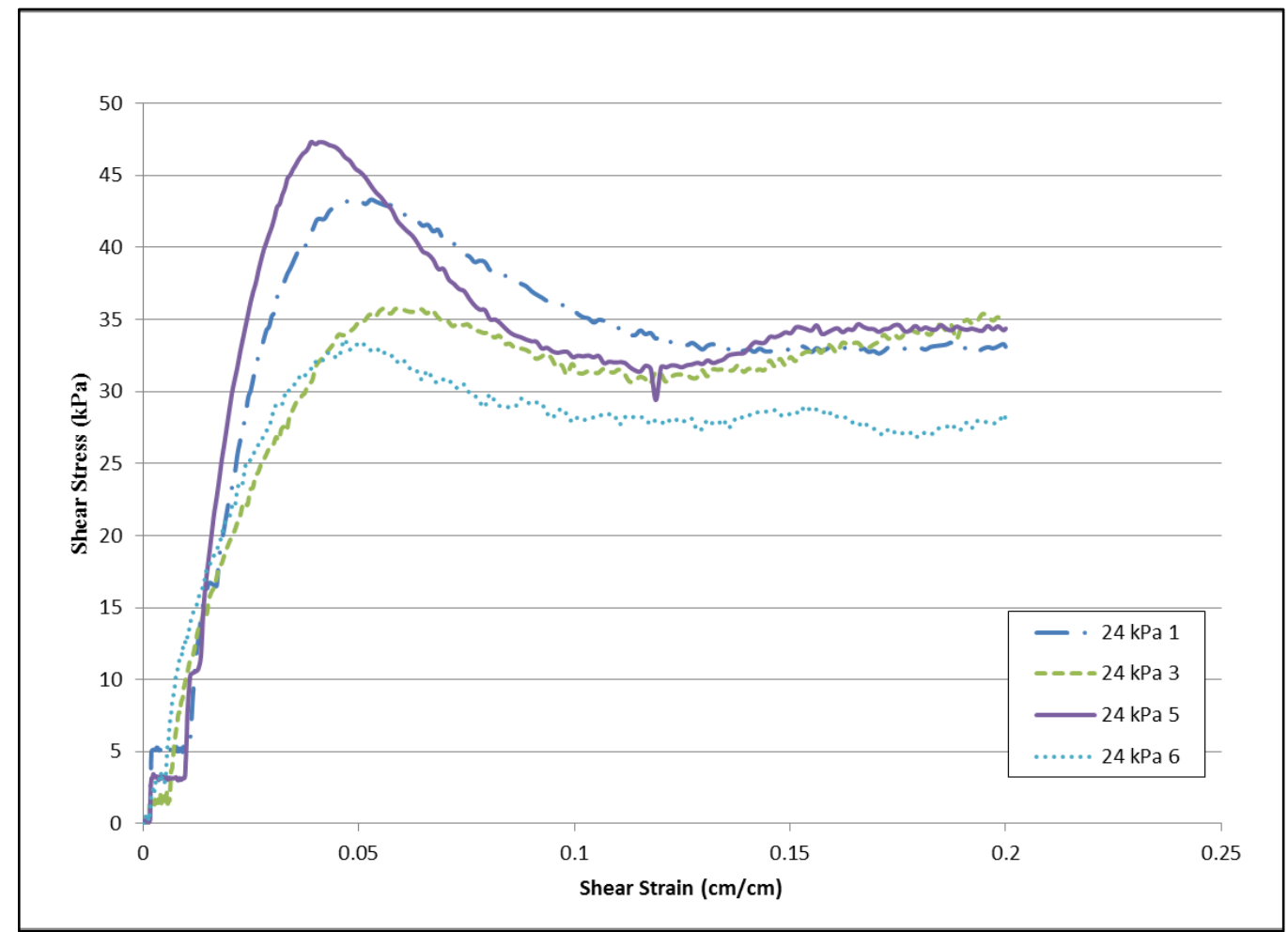

Figure 3.16: Shear Stress vs. shear strain plot for shale direct shear specimens compacted to $34 \%$ of standard proctor energy under shallow (surface) loading condition. 
Higher uncertainty was present in samples subjected to lower normal forces. Due to the lower forces at work, small differences due to variation in sample preparation or particle orientation along the failure plane could lead to significant differences in the calculated friction angle. Differences were present in the samples with higher applied forces, but due to the larger numbers were not as apparent.

Throughout the testing, the dry density calculated from the molds from which the specimens were derived was consistently lower than the target values from section 3.1.5. The differences are summarized in Table 3.23.

Table 3.23: Summary of differences between direct shear compaction mold specimens and compaction test results

\begin{tabular}{|c|c|c|c|c|c|c|}
\hline Sample & $\begin{array}{c}\text { Target } \\
\text { Moisture } \\
\text { Content }\end{array}$ & $\begin{array}{c}\text { Average } \\
\text { obtained } \\
\text { moisture } \\
\text { content }\end{array}$ & $\begin{array}{c}\text { Difference } \\
(\mathbf{\%})\end{array}$ & $\begin{array}{c}\text { Target } \\
\mathbf{d r y} \\
\mathbf{d e n s i t y} \\
\mathbf{( k N / \mathbf { m } ^ { 3 } )}\end{array}$ & $\begin{array}{c}\text { Average } \\
\text { achieved } \\
\mathbf{d r y} \\
\mathbf{d e n s i t y} \\
\mathbf{( k N / \mathbf { m } ^ { 3 } )}\end{array}$ & $\begin{array}{c}\text { Difference } \\
(\mathbf{\%})\end{array}$ \\
\hline $\begin{array}{c}\text { Shale, 11\% } \\
\text { Proctor } \\
\text { Compaction }\end{array}$ & 17.5 & 16.36 & $6.49 \%$ & 14.6 & 12.10 & $17.12 \%$ \\
\hline $\begin{array}{c}\text { Shale, 34\% } \\
\text { Proctor } \\
\text { Compaction }\end{array}$ & 17.0 & 16.66 & $2.00 \%$ & 15.1 & 13.15 & $12.93 \%$ \\
\hline $\begin{array}{c}\text { Shale, } \\
\text { Standard } \\
\text { Proctor } \\
\text { Compaction }\end{array}$ & 14.3 & 12.99 & $9.17 \%$ & 15.9 & 13.61 & $14.39 \%$ \\
\hline
\end{tabular}

The moisture content difference is a result of error in the laboratory testing, and likely contributes slightly to the dry density difference. However, nearly a $13 \%$ difference was observed for the $34 \%$ compaction samples in which the moisture content was near the target. Additionally, the test procedure for each compaction test remained consistent with those used in section 3.1.5. Since the sample material for the compaction test and direct shear test were taken from two separate sampling dates at the Royal Scot site, it was concluded that the difference was due to variation in the material. 


\subsubsection{0) Comparison to literature values and discussion}

Table 3.24 shows the aggregate lab test results as well as values obtained from literature for comparison.

Table 3.24: Comparison of coarse coal refuse lab testing values to literature values

\begin{tabular}{|c|c|c|c|c|}
\hline Property & Lab Value & $\begin{array}{l}\text { Hegazy et } \\
\text { al. } 2004\end{array}$ & $\begin{array}{c}\text { D'Appolonia, } \\
2009\end{array}$ & $\begin{array}{c}\text { Tolikonda, } \\
\text { 2010/ } \\
\text { Quaranta } \\
\text { and } \\
\text { Tolikonda, } \\
2011\end{array}$ \\
\hline $\mathbf{D}_{10}(\mathrm{~mm})$ & 0.525 & $<0.075$ & 0.09 & 0.53 \\
\hline $\mathbf{D}_{30}(\mathrm{~mm})$ & 1.73 & $0.10-0.50$ & $0.2-12$ & 1.3 \\
\hline $\mathbf{D}_{50}(\mathbf{m m})$ & 4.33 & $0.61-1.85$ & $1-16$ & 2.2 \\
\hline $\mathbf{D}_{60}(\mathrm{~mm})$ & 6.85 & $1.13-2.91$ & $2-22$ & 2.7 \\
\hline \% Passing No. 200 Sieve & 3 & $\begin{array}{l}8.97- \\
30.55\end{array}$ & $1.5-20$ & 8 \\
\hline $\mathbf{C}_{\mathrm{u}}$ & 12.93 & -- & -- & 5.09 \\
\hline Plasticity Index & 4 & -- & $<12$ & 7.34 \\
\hline Specific Gravity & $1.91-2.19$ & $1.71-2.33$ & $1.5-2.8$ & 2.54 \\
\hline Dry Unit Weight $\left(\mathrm{kN} / \mathrm{m}^{3}\right)$ & $12.1-16$ & $18.8-20.6$ & 18.25 & $18.22-19.58$ \\
\hline Dry Unit Weight $\left(\mathbf{l b} / \mathbf{f t}^{\mathbf{3}}\right)$ & $\begin{array}{l}77.02- \\
101.85\end{array}$ & $\begin{array}{l}119.67- \\
131.13\end{array}$ & 116.17 & $\begin{array}{l}115.98- \\
124.64\end{array}$ \\
\hline Hydraulic Conductivity (cm/s) & $\begin{array}{c}2.29 \mathrm{E}-7 \text { to } \\
4.22 \mathrm{E}-4\end{array}$ & $\begin{array}{l}3 \mathrm{E}-6 \text { to } \\
5.7 \mathrm{E}-5\end{array}$ & $1 \mathrm{E}-8$ to $1 \mathrm{E}-4$ & $\begin{array}{c}2.1 \mathrm{E}-5 \text { to } \\
5 \mathrm{E}-4\end{array}$ \\
\hline $\begin{array}{c}\text { Angle of Internal Friction } \\
\text { (degrees) }\end{array}$ & 41.4-43.8 & $31-37$ & $27-40$ & -- \\
\hline $\begin{array}{c}\text { Cohesionless angle of internal } \\
\text { friction (degrees) }\end{array}$ & 43.21-44.96 & $34-40$ & -- & -- \\
\hline Cohesion (kPa) & $16.99-25.6$ & $1-25$ & $0-19$ & -- \\
\hline
\end{tabular}

Compared to the literature values, the lab test results show the following trends:

- The $\mathrm{D}_{10}$ particle size observed in the lab testing was significantly larger than those described by literature. Additionally, laboratory samples had fewer particles passing a No. 200 sieve. Together these indicate that the laboratory sample's smallest particles were larger than the literature samples.

- The $\mathrm{D}_{30}, \mathrm{D}_{50}$, and $\mathrm{D}_{60}$ particle sizes were larger than Hegazy et al., (2004) and Tolikonda, (2010), but fell within the range indicated by D'Appolonia, (2009).

- The Plasticity index and specific gravity were within the ranges established by literature.

- The achieved dry unit weights were $4-8 \mathrm{kN} / \mathrm{m}^{3}$ lower than any values shown in past studies.

- Hydraulic conductivity test results were within the literature defined range. 
- The calculated angle of friction was larger than literature values, and the cohesion was on the upper end of the defined range.

It is not unexpected that some of the test results fell on the edge and even outside of the typical ranges. Coarse coal refuse has differing values as a result of the changes of rock strata properties and the efficiency of coal preparation plants. Some change in the properties was even observed between the samples of coarse coal refuse obtained from the Royal Scot site.

The high calculated angle of friction for the coarse coal refuse in the laboratory testing is a concern which should be addressed in future work. It is theorized that the angle calculated by means of the direct shear may be too high as a result of the particles angularity and confinement in the direct shear box. To verify that the angle is actually as high as indicated by the direct shear tests, it is recommended that isotropic consolidated drained (CD) and isotropic consolidated undrained (CU) triaxial tests be conducted on the coarse coal refuse material as was done in Hegazy et al., (2004).

\section{2) MGro ${ }^{\mathrm{TM}}$ Material Testing}

MGro $^{\mathrm{TM}}$ short paper fiber was obtained from the WestRock (formerly MeadWestVaco) paper mill in Covington, Virginia, in two different sample shipments. The first sample was dated July 21, 2015, and was used for initial material investigations, moisture content measurement, and specific gravity testing. This sample was maintained its natural, moist condition for all testing.

A second sample was obtained on August 21, 2015 directly from the paper mill. This sample of seven five-gallon buckets of material was placed into large, open containers upon arrival in Morgantown. The material was then allowed to dry outside, as mold and decomposition plagued prior tests with the moist material. The dried $\mathrm{MGro}^{\mathrm{TM}}$ was then remoistened to the desired moisture content for compaction and strength testing.

\subsection{1) Visual Inspection}

Visual examination of the MGro ${ }^{\mathrm{TM}}$ samples showed the mixed composition. Clumped masses of fibrous material of varying were observed along with wood chips and clay-like material. The material swelled noticeably when water was added. A typical sample of MGro ${ }^{\mathrm{TM}}$ can be observed in Figure 3.17. 


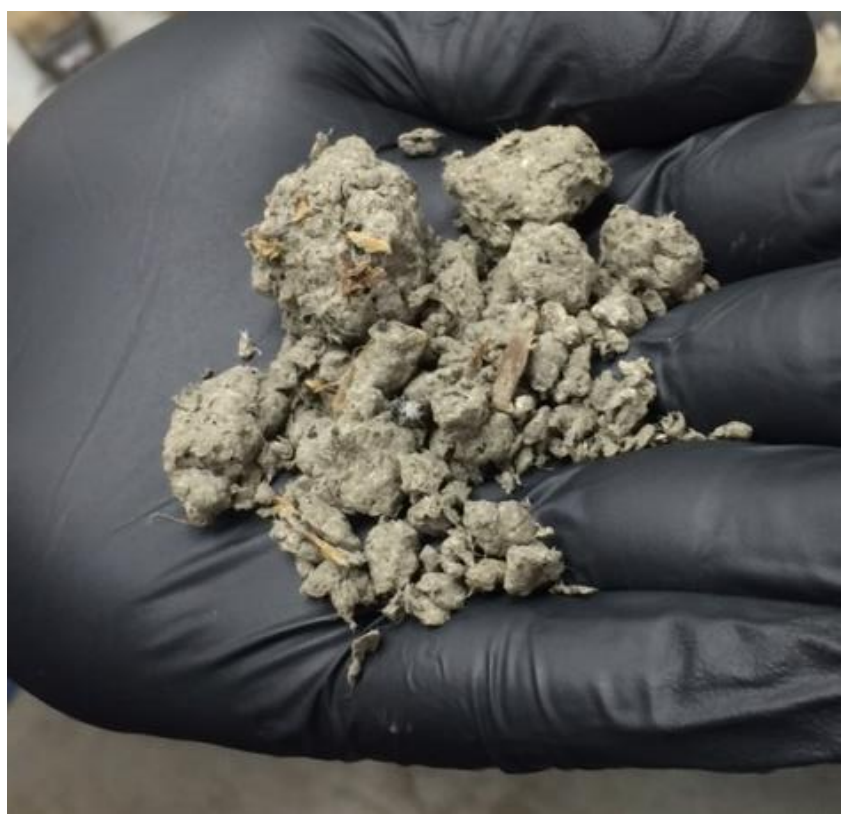

Figure 3.17: Typical MGro ${ }^{\mathrm{TM}}$ sample

\subsection{2) Moisture Content}

Moisture content testing was performed according to ASTM standard test method D 2216-05. One sample from each of the bags provided in the first shipment of material was tested. The results of the moisture content testing are provided in Table 3.25.

Table 3.25: Moisture content testing results for MGro ${ }^{\mathrm{TM}}$

\begin{tabular}{|l|l|}
\hline Average Moisture Content (\%): & $\mathbf{1 2 8 . 5 8}$ \\
\hline Sample Standard Deviation (s) & 12.776 \\
\hline Coefficient of Variation (COV) & 0.099 \\
\hline
\end{tabular}

The moisture content for the $\mathrm{MGro}^{\mathrm{TM}}$ material is over $100 \%$ indicating that more water is present in the sample than solids. This is an expected finding as $\mathrm{MGro}^{\mathrm{TM}}$ is classified as a sludge material. One sample were observed to have a much higher moisture content than others, which was likely the result of water from ice melt in the shipping container leaking into the bag. As it was vastly different than the other samples, it was removed from the testing.

\subsection{3) Grain Size Distribution}

After the material collected in the second batch had dried, a grain size distribution was completed according to ASTM D 422-63. Duplicate testing was completed to ensure accuracy in the data. The data for both tests was consistent as represented by the coefficient of variation of 0.031 for the uniformity coefficient and 0.035 for the coefficient of gradation. Results from the test, including the critical indices and statistics are shown in Table 3.26 through Table 3.28.

Table 3.29 gives the USCS classification of the soil. The grain size distribution curve is shown in Figure 3.18. 
Table 3.26: Critical Indices from MGro ${ }^{\mathrm{TM}}$ grain size testing

\begin{tabular}{|c|c|c|c|}
\hline \multicolumn{4}{|c|}{ Results } \\
\hline Critical Indices & Test 1 & Test 2 & Average \\
\hline $\mathrm{D}_{90}$ & 9.0 & 10.0 & 9.5 \\
\hline $\mathrm{D}_{60}$ & 4.0 & 4.4 & 4.2 \\
\hline $\mathrm{D}_{50}$ & 3.2 & 3.5 & 3.35 \\
\hline $\mathrm{D}_{30}$ & 2.00 & 2.10 & 2.05 \\
\hline $\mathrm{D}_{25}$ & 1.70 & 1.90 & 1.80 \\
\hline $\mathrm{D}_{10}$ & 0.95 & 1.00 & 0.975 \\
\hline Uniformity Coefficient, $\mathbf{C}_{\mathbf{u}}$ & $\mathbf{4 . 2 1}$ & $\mathbf{4 . 4 0}$ & $\mathbf{4 . 3 1}$ \\
\hline Coefficient of Gradation, $\mathbf{C}_{\mathbf{c}}$ & $\mathbf{1 . 0 5}$ & $\mathbf{1 . 0 0}$ & $\mathbf{1 . 0 3}$ \\
\hline
\end{tabular}

Table 3.27: Uniformity Coefficient Statistics from MGro ${ }^{\mathrm{TM}}$ grain size testing

\begin{tabular}{|l|l|}
\hline Uniformity Coefficient, $\mathbf{C}_{\mathbf{u}}$ \\
\hline Average Uniformity Coefficient (\%) & 4.305 \\
\hline Sample Standard Deviation (s) & 0.134 \\
\hline Coefficient of Variation (COV) & 0.031 \\
\hline
\end{tabular}

Table 3.28: Coefficient of Gradation Statistics from MGro ${ }^{\mathrm{TM}}$ grain size testing

\begin{tabular}{|l|l|}
\hline Coefficient of Gradation, $\mathbf{C}_{\mathbf{c}}$ \\
\hline $\begin{array}{l}\text { Average Coefficient of Gradation } \\
(\%)\end{array}$ & 1.027 \\
\hline Sample Standard Deviation (s) & 0.036 \\
\hline Coefficient of Variation (COV) & 0.035 \\
\hline
\end{tabular}

Table 3.29: USCS Classification for dried MGro ${ }^{\mathrm{TM}}$

\begin{tabular}{|l|l|}
\hline USCS Soil Classification & USCS Symbol \\
\hline Poorly Graded sand with gravel & SP \\
\hline
\end{tabular}




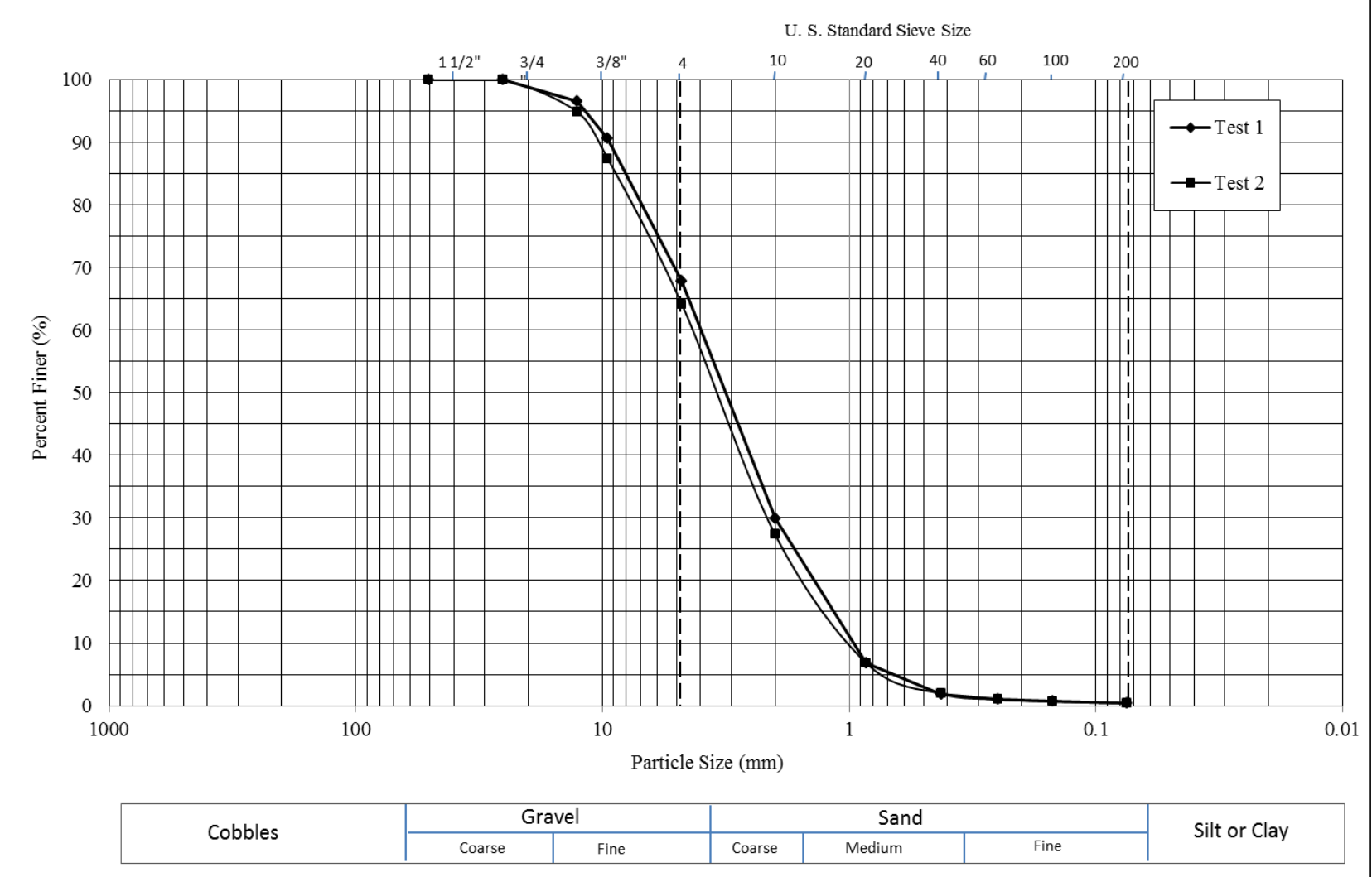

Figure 3.18: As Received Grain Size Distribution-Dried MGro ${ }^{\mathrm{TM}}$ material

The $\mathrm{MGro}^{\mathrm{TM}}$ was noted to have a relatively poorly-graded distribution. A majority of particles fell between $10 \mathrm{~mm}$ and $1 \mathrm{~mm}$ and very few fines were present. Classifying this material according to the USCS system and ASTM 2487 gives a designation as a poorly graded sand with gravel.

\subsection{4) Specific Gravity}

Specific gravity testing was performed according to ASTM standard test method D-854. Tests were run for each of the eight samples obtained from MeadWestVaco. Due to the moist material particles' tendency to stick together, the samples were not sieved to cut out particles larger than a U.S. No. 4. Instead, the samples were run as-received. An average specific gravity of 1.92 was obtained from the eight samples with a low value of 1.80 and a high value of 1.98 . High precision in the tests is indicated with a coefficient of variation of 0.030 . The results for test are shown in Table 3.30.

Table 3.30: $M$ Gro $^{\mathrm{TM}}$ Specific gravity test 1 results and statistics

\begin{tabular}{|l|l|}
\hline Average Specific Gravity, $\mathbf{G}_{\mathbf{t}}:$ & $\mathbf{1 . 9 2}$ \\
\hline Sample Standard Deviation for $\mathrm{G}_{\mathrm{t}}(\mathrm{s})$ & 0.057 \\
\hline Coefficient of Variation for $\mathrm{G}_{\mathrm{t}}(\mathrm{COV})$ & 0.030 \\
\hline
\end{tabular}


A second specific gravity test was completed on the $\mathrm{MGro}^{\mathrm{TM}}$ obtained in the second sample once the material had air dried. As required by ASTM standard D-854, all particles retained on a U.S. No. 4 sieve were removed from the sample prior to testing. Triplicate testing was completed on the material to ensure accuracy. An average specific gravity of 2.21 was determined for this testing. Extremely high precision was achieved in the three tests as indicated by the 0.005 coefficient of variation. The results for the tests are shown in Table 3.31

Table 3.31: MGro ${ }^{\mathrm{TM}}$ Specific gravity test 2 results and statistics

\begin{tabular}{|l|l|}
\hline Average Specific Gravity, $\mathbf{G}_{\mathbf{t}}$ : & $\mathbf{2 . 2 1}$ \\
\hline Sample Standard Deviation for $\mathrm{G}_{\mathrm{t}, \mathrm{s}}$ & 0.011 \\
\hline Coefficient of Variation for $\mathrm{G}_{\mathrm{t}}(\mathrm{COV})$ & 0.005 \\
\hline
\end{tabular}

There is significant difference between the first sample and the second sample results. The primary reason for this difference is the inclusion of the larger particles in the first test. In the visual inspection of the $\mathrm{MGro}^{\mathrm{TM}}$, it was apparent that this material was not homogenous and that its component particles did not have the same properties. Additional explanations include sample variations in the manufacturing process and material changes due to decomposition during drying.

\subsection{5) Compaction}

Compaction testing was carried out on the $\mathrm{MGro}^{\mathrm{TM}}$ material to find the maximum dry density in accordance with ASTM D-698. The tests were completed at a standard proctor compaction effort $\left(592.5 \mathrm{~kJ} / \mathrm{m}^{3}\right)$ and at 7 moisture contents. After drying out the sample to an approximate moisture content of $7-9 \%$, water was added to the sample to achieve the desired moisture content. It was observed that the moisture was absorbed into the $\mathrm{MGro}^{\mathrm{TM}}$ paper fiber material over a period of time, so appropriate standing time was allowed for all particles to be equally moistened.

The compaction curve for MGro ${ }^{\mathrm{TM}}$ is shown in Figure 3.19 and the test data is given in Appendix A. The optimum dry density of the material was calculated to be approximately 8 $\mathrm{kN} / \mathrm{m}^{3}$ at a moisture content of $63 \%$. As the samples used for compaction testing were from the second batch of $\mathrm{MGro}^{\mathrm{TM}}$, the specific gravity from this sample was used in the calculations. 


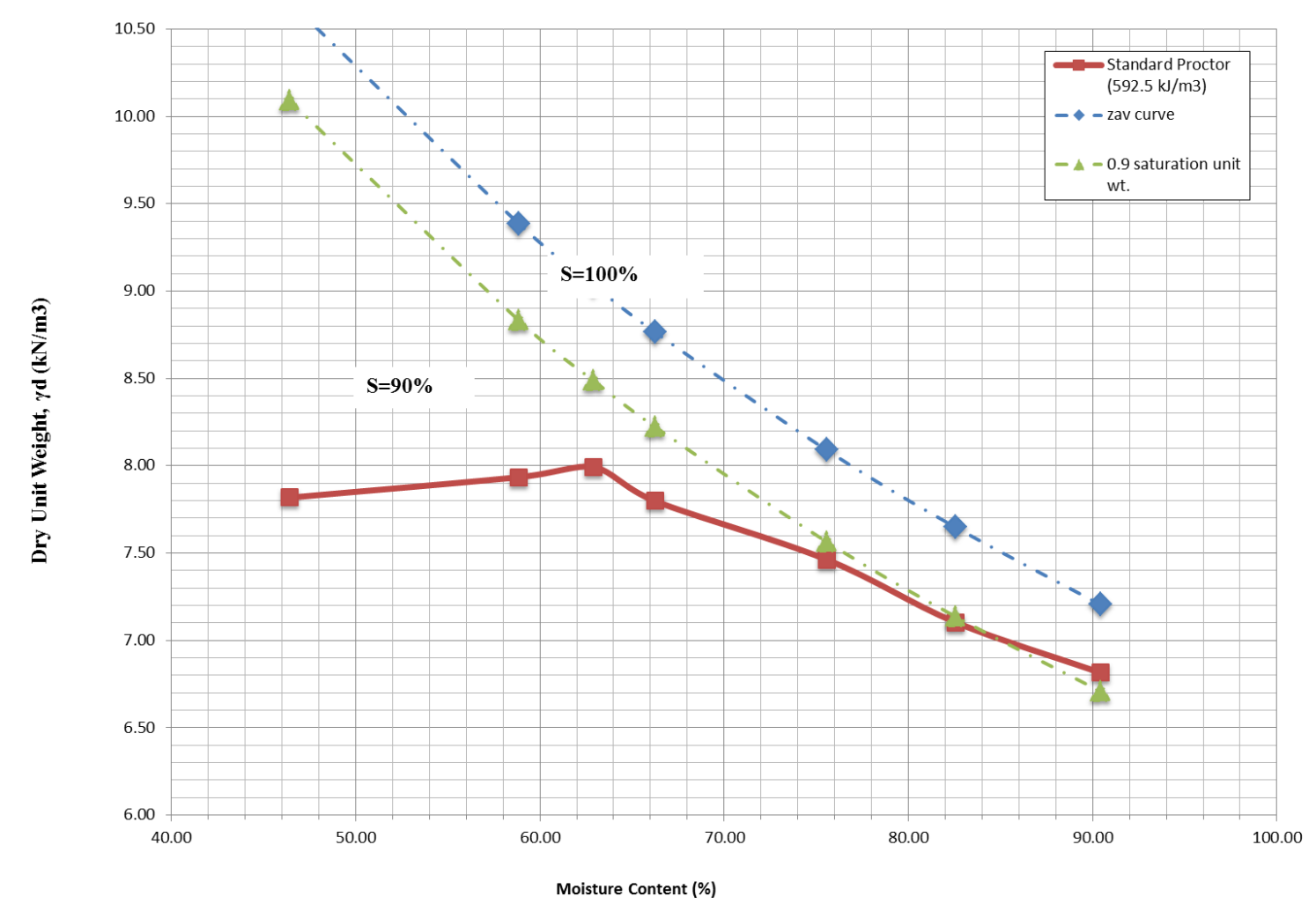

Figure 3.19: MGro $^{\mathrm{TM}}$ Compaction Curve for Standard Proctor effort

\subsection{6) Discussion of MGro ${ }^{\mathrm{TM}}$ testing results}

Several difficulties were encountered while working with the MGro $^{\mathrm{TM}}$ material. These problems included the following:

1. Water Absorption and swelling

During specific gravity testing it was critical to not wet the $\mathrm{MGro}^{\mathrm{TM}}$ material until it had all been placed into the pycnometer. Water addition resulted in the material absorbing it and swelling which would clog the pycnometer neck. Trying to clear the clog was difficult as the material would aggregate together when pushed on and form a bigger blockage.

The effects of water addition were also observed in the MGro ${ }^{\mathrm{TM}}$ samples where ice-water melt is believed to have leaked into the storage bag. These samples had significantly moisture content values than the others and were more difficult to work with as particles aggregated together.

2. Shear Strength testing issues

Shear Strength testing had been planned for the MGro ${ }^{\mathrm{TM}}$. However, several issues were encountered during the completion of the tests. A full consolidation schedule prior to shear testing on the $\mathrm{MGro}^{\mathrm{TM}}$ paper fiber was impossible. During a test series where the schedule was 
employed, the material consolidated to the machine-allowed maximum (approximately 39\% strain) well before the largest normal force was applied. This invalidated the test results and the machines could not be corrected as allowance of additional consolidation would have pushed the entire sample below the shear plane.

To compensate for this issue, shearing was initiated in an unconsolidated condition where only a seating load was applied. However, results yielded an unrealistically high angle of internal friction which was determined to be the result of pore pressure effects within the specimen during testing. After this test, it was determined that accurate direct shear testing could not be performed on the $\mathrm{MGro}^{\mathrm{TM}}$ and that triaxial testing would be required for strength testing of any soil samples containing MGro ${ }^{\mathrm{TM}}$.

\section{Decomposition}

It was clear that the $\mathrm{MGro}^{\mathrm{TM}}$ material was undergoing decomposition during the testing. From the first week of testing with Sample number 1 to the third week, the material became darker in its appearance and the moisture contents from testing increased from approximately $130 \%$ to nearly $170 \%$. When stored in a closed container, the creation of gases was observed. Additionally, the material gave off a strong odor of decay. While the complete impacts of decomposition were not studied, this process would likely have impacts on the material properties of $\mathrm{MGro}^{\mathrm{TM}}$ and investigation of the changes may be merited.

Testing with the second sample of $\mathrm{MGro}^{\mathrm{TM}}$ was completed with air-dried samples. This process seemed to reduce the decay beyond any initial decomposition during the drying and reduced odor problems significantly.

\section{3) Shale/MGroTM blend testing}

The shale and MGro ${ }^{\mathrm{TM}}$ material tested both have benefits and detriments for usage as a construction material at the Royal Scot site. The shale has high strength properties for construction but causes any water which infiltrates to become acidic as seen in the shale permeability testing and at the Royal Scot site in its current state. Meanwhile, paper sludges, like MGro $^{\mathrm{TM}}$ do not offer the same strength as the shale but offers soil amending characteristics to increase vegetative growth and minimize acid generation. To determine if a mixture of the shale and $\mathrm{MGro}^{\mathrm{TM}}$ could serve as a suitable cap on the final Royal Scot site reclamation, soil tests were performed on blended mixtures of the materials.

Two blends of the shale and $\mathrm{MGro}^{\mathrm{TM}}$ materials were decided upon for testing. These included one composed of $60 \%$ shale and $40 \% \mathrm{MGro}^{\mathrm{TM}}$ and another composed of $80 \%$ shale and $20 \%$ MGro $^{\mathrm{TM}}$. The materials will be identified in the report as 60/40 blend and 80/20 blend, respectively. In order provide the most usable data for the reclamation project, the blends were assembled by volume, rather than by mass.

Compaction and grain-size testing were completed for both blends of material while permeability and strength testing were only completed for the 60/40 blend, which was deemed to offer the greatest benefits for minimizing acid generation and increasing growth of vegetation. 
All tests were performed in accordance with applicable ASTM standards and at least duplicate testing was used to ensure accuracy in the results.

\subsection{1) Grain Size Distributions}

Grain Size distributions were completed for the two proposed blends of shale and MGro ${ }^{\mathrm{TM}}$ in accordance with ASTM D 422-63. One test for each blend was completed and the results were plotted on the same graph as the shale and MGro ${ }^{\text {TM }}$ compaction curves (modified to a U.S. \#4 topsize) completed earlier. Critical indicies, the uniformity coefficient, and coefficient of gradation from the testing are shown in Table 3.32 and the grain size distribution curves can be seen in Figure 3.20.

Table 3.32: Critical Indices for blend grain size distribution tests

\begin{tabular}{|c|r|r|r|r|}
\hline \multicolumn{5}{|c|}{ Results } \\
\hline Critical Indices & $\begin{array}{r}60 / 40 \\
\text { blend }\end{array}$ & $\begin{array}{r}80 / 20 \\
\text { blend }\end{array}$ & Shale & MGro $^{\mathrm{TM}}$ \\
\hline $\mathrm{D}_{90}$ & 3.9 & 3.9 & 3.9 & 4.1 \\
\hline $\mathrm{D}_{60}$ & 1.9 & 2.1 & 1.9 & 2.6 \\
\hline $\mathrm{D}_{50}$ & 1.7 & 1.6 & 1.5 & 2.2 \\
\hline $\mathrm{D}_{30}$ & 0.99 & 0.90 & 0.90 & 1.6 \\
\hline $\mathrm{D}_{25}$ & 0.85 & 0.75 & 0.70 & 1.4 \\
\hline $\mathrm{D}_{10}$ & 0.30 & 0.30 & 0.27 & 0.85 \\
\hline Uniformity Coefficient, $\mathbf{C}_{\mathbf{u}}$ & $\mathbf{6 . 3 3}$ & $\mathbf{7 . 0 0}$ & $\mathbf{7 . 0 4}$ & $\mathbf{3 . 0 6}$ \\
\hline Coefficient of Gradation, $\mathbf{C}_{\mathbf{c}}$ & $\mathbf{1 . 7 2}$ & $\mathbf{1 . 2 9}$ & $\mathbf{1 . 5 8}$ & $\mathbf{1 . 1 6}$ \\
\hline
\end{tabular}

As can be observed in Figure 3.20, the shale and blended materials follow approximately the same grain size distribution while the $\mathrm{MGro}^{\mathrm{TM}}$ takes its own distribution. The shale has a larger amount of particles smaller than $1 \mathrm{~mm}$ and is generally more 'well-graded' than the MGro ${ }^{\text {TM }}$ which is more poorly graded with most of its particle sizes in the sample falling between a \#4 sieve and $1 \mathrm{~mm}$. 


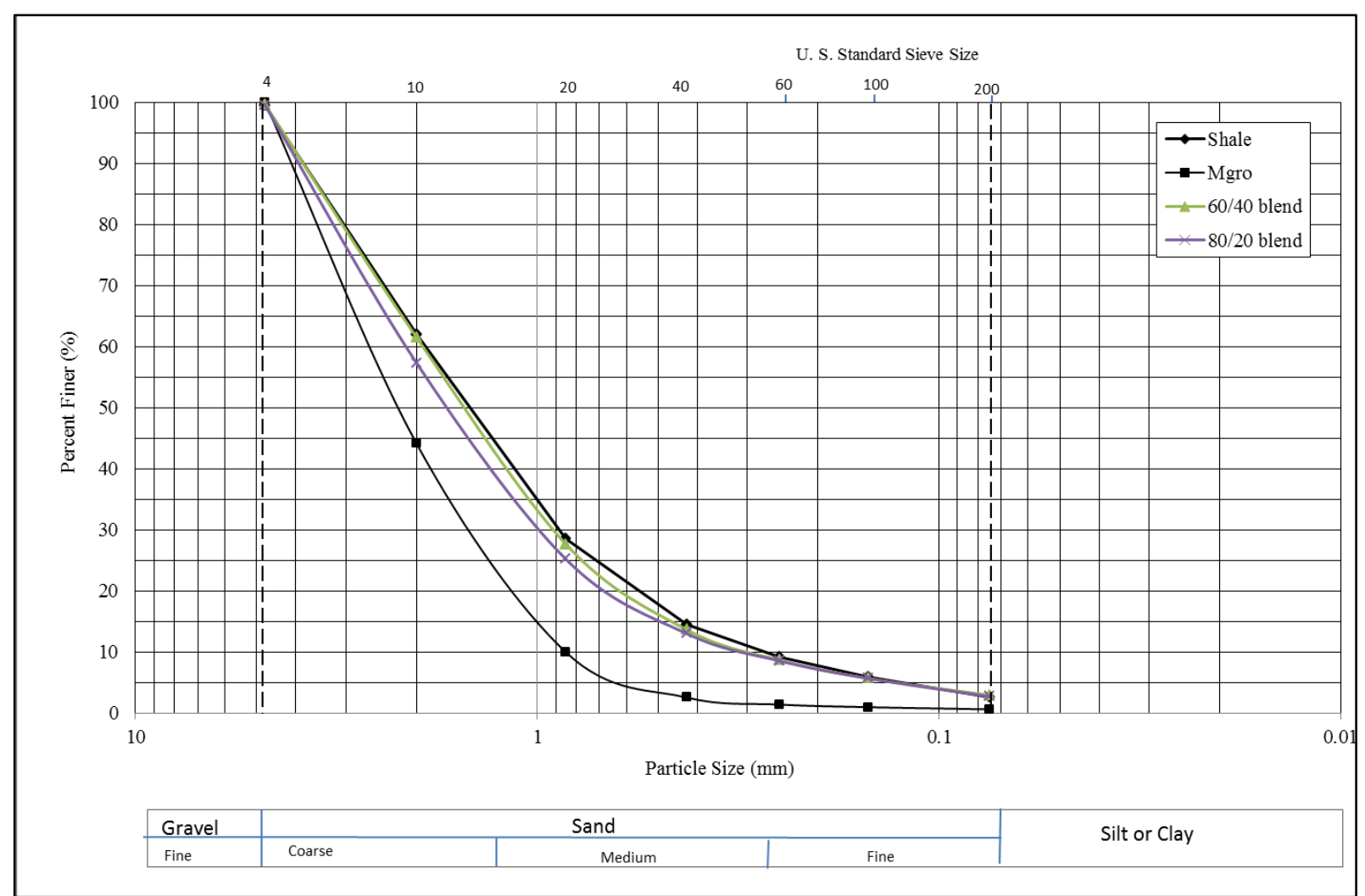

Figure 3.20: Grain Size Distributions for Royal Scot materials (4.76mm topsize)

\subsection{2) Compaction}

Each of the shale/MGro ${ }^{\mathrm{TM}}$ blends was tested at a standard Proctor compaction effort in order to determine the maximum dry density of the material as well as explore the density/moisture content relationship. These parameters are important to accurately model the slope stability for possible designs.

Compaction curves for the $60 / 40$ and $80 / 20$ blends were plotted along with the curves for the shale and $\mathrm{MGro}^{\mathrm{TM}}$, both at standard proctor energy. These curves are shown in Figure 3.21 and the maximum dry unit weights and optimum moisture contents are summarized in Table 3.33. Compaction data and the individual curves for each blend are provided in Appendix A. 


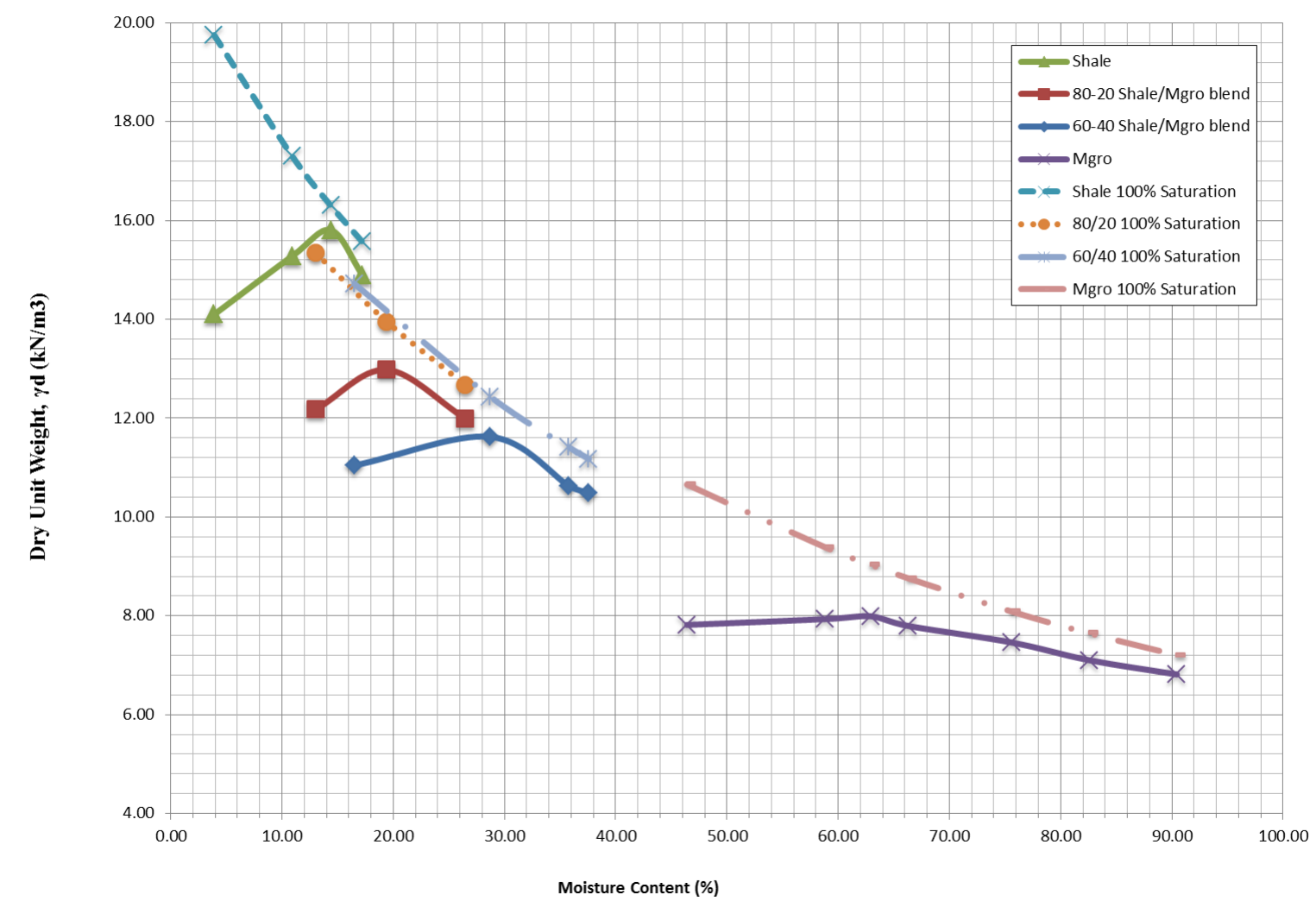

Figure 3.21: Compaction curves for shale, MGro, and blended materials at standard proctor energy

Table 3.33: Summary of compaction test results of Royal Scot materials

\begin{tabular}{|c|c|c|}
\hline $\begin{array}{c}\text { Material } \\
\text { (all compacted at standard } \\
\text { proctor energy) }\end{array}$ & $\begin{array}{c}\text { Maximum Dry Unit Weight, } \\
\gamma_{\mathrm{d}} \\
\left(\mathrm{kN} / \mathrm{m}^{3}\right)\end{array}$ & $\begin{array}{c}\text { Optimum moisture content, } \\
w \\
\% \\
\end{array}$ \\
\hline Shale & 15.90 & 14.3 \\
\hline $80 / 20$ blend & 13.00 & 19.0 \\
\hline $60 / 40$ blend & 11.70 & 28.0 \\
\hline MGro $^{\mathrm{TM}}$ & 8.00 & 63.0 \\
\hline
\end{tabular}

As the percentage of shale decreases for each material the maximum dry unit weight also decreases and the optimum moisture content increases. Additionally, the curve shape becomes flatter and there is less difference between the maximum dry unit weight and the measurements on both the dry side and wet side of optimum.

\subsection{3) Permeability}

Flex-wall permeability testing was conducted in accordance with ASTM 5084 for the 60/40 shale/ MGro ${ }^{\mathrm{TM}}$ material. As the test cell set-up is essentially the same as a triaxial test specimen, the samples were tested for hydraulic conductivity prior to being sheared. As the samples were to simulate a surface layer, only minimal compaction was applied. 
Duplicate testing was completed for two specimens prepared in a $7.11 \mathrm{~cm}(2.8$ ") diameter split ring mold and compacted to approximately $110 \mathrm{~kJ} / \mathrm{m}^{3}$ (3 layers with 3 blows/layer or approximately $18.5 \%$ Proctor). This energy was determined to be the least which could be applied and still create a specimen which would stay together enough for the flex-wall cell to be assembled. The sample was then cut to a height of approximately $14.2 \mathrm{~cm}$ (5.6") to achieve a 2:1 length to diameter ratio. The flexwall permeability tests were run at a gradient of $i=5$. The specimen data and calculated hydraulic conductivity are given in Table 3.34. The average hydraulic conductivity for the two tests was calculated to be $8.61 \times 10^{-4} \mathrm{~cm} / \mathrm{s}$. Figure 3.22 shows the hydraulic conductivity plotted against pore volumes of permeant water passed through the specimen. The hydraulic conductivity values stabilized, indicating that a stable filter condition had been reached.

Table 3.34: Specimen data and hydraulic conductivity test results for 60/40 blend

\begin{tabular}{|c|c|c|c|c|c|c|c|}
\hline Test & $\begin{array}{c}\text { Water } \\
\text { Content, } \\
\% W\end{array}$ & $\begin{array}{c}\text { Dry Unit } \\
\text { Weight of } \\
\text { Compacted } \\
\text { Specimen, } \gamma_{d} \\
\text { KN/m } / \mathrm{m}^{3} / \mathrm{lb} / \mathrm{ft}^{3}\end{array}$ & $\begin{array}{c}\text { Degree of } \\
\text { Saturation } \\
\text { S }\end{array}$ & $\begin{array}{c}\text { Porosity } \\
\text { n }\end{array}$ & $\begin{array}{c}\text { Saturated } \\
\text { Water } \\
\text { Content, } \\
\mathbf{w}_{\text {sat }}(\%)\end{array}$ & $\begin{array}{c}\text { Hydraulic } \\
\text { Conductivity } \\
\text { (average of last } \\
5 \text { points), } \mathbf{k} \\
(\mathrm{cm} / \mathrm{s})\end{array}$ & $\begin{array}{l}\text { Coefficient of Variation } \\
\text { (last } 5 \text { points of hydraulic } \\
\text { conductivity) }\end{array}$ \\
\hline 1 & 28.54 & $\begin{array}{c}9.40 \\
59.88\end{array}$ & 0.53 & 0.52 & 54.12 & $1.03 \mathrm{E}-03$ & 0.069 \\
\hline 2 & 30.18 & $\begin{array}{c}9.04 \\
57.58 \\
\end{array}$ & 0.52 & 0.54 & 58.25 & $6.92 \mathrm{E}-04$ & 0.164 \\
\hline
\end{tabular}

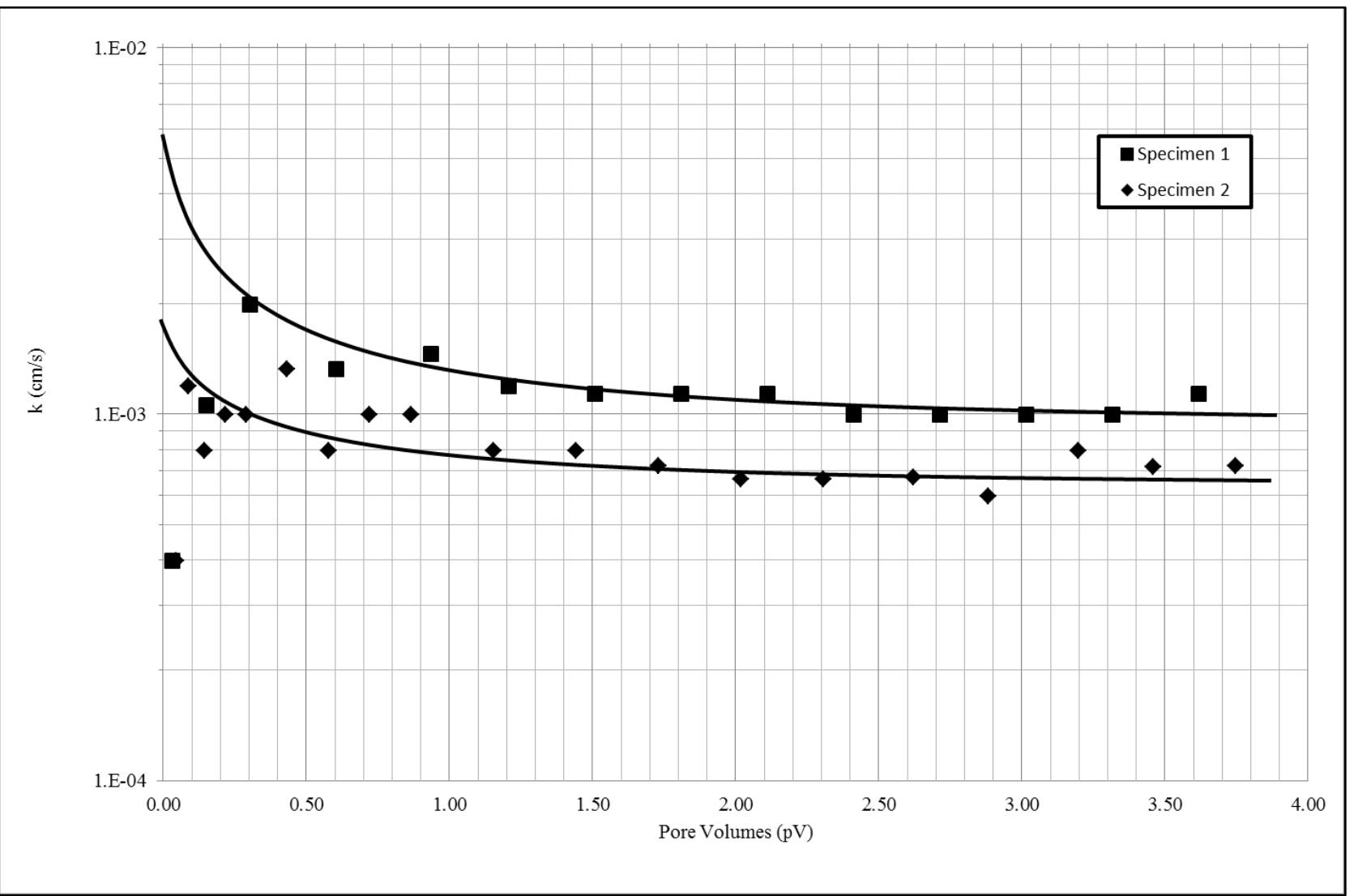

Figure 3.22: Hydraulic conductivity vs. pore volumes plot for 60/40 blend 


\subsection{4) Strength Testing (Consolidated Undrained Triaxial)}

After completing permeability testing, the $60 / 40$ shale/MGro ${ }^{\mathrm{TM}}$ specimens were used for triaxial testing. A Geotac Sigma 1 triaxial testing apparatus was used to complete this stage of the laboratory program.

In order to simulate impact of pore pressure buildup in the slope, consolidated-undrained (CU) tests (ASTM 4767-11) were completed. In this test, the specimen is consolidated under the desired stress condition, and then sheared with all drainage valves closed. This allows pore pressure to build within the specimen during shearing (Holtz and Kovacs, 2011). While this condition may not be present at the field location, with the 60/40 layer making up the surface and being underlain by a drainage system, the $\mathrm{CU}$ test would give a conservative estimate of the strength parameters.

Tests were completed at two consolidation pressures, both corresponding to different possible stress conditions at the site depending on the depth of the blended growth layer. A moist unit weight of the layer was estimated to be $78 \mathrm{lb} / \mathrm{ft}^{3}$ and the stress was estimated. A summary of the calculations used for the stress estimation are shown in Table 3.35.

Table 3.35: Summary of triaxial testing conditions

\begin{tabular}{|c|c|c|c|}
\hline \multirow{2}{*}{ Test Condition } & Designed Depth & Calculated Stress & Stress used for test \\
\cline { 2 - 4 } & $\mathrm{ft}(\mathrm{m})$ & $\mathrm{lb} / \mathrm{ft}^{2}\left(\mathrm{kN} / \mathrm{m}^{2}\right)$ & $\mathrm{psi}\left(\mathrm{kN} / \mathrm{m}^{2}\right)$ \\
\hline 1 & $3(0.91)$ & $1.63(0.078)$ & $2.00(0.095)$ \\
\hline 2 & $12(3.65)$ & $6.50(0.311)$ & $6.50(0.311)$ \\
\hline
\end{tabular}

The three foot depth was selected as a minimum thickness value suitable for testing and the calculated stress was rounded up for easier data input. The larger test depth, 12 feet, despite being beyond the likely thickness of the layer was selected to give enough separation between the tests for analysis.

Prior to the triaxial testing process, the test specimens had been through a permeability test, so they were assumed to be in a stable saturation state and no 'back-pressure saturation' was completed. Instead, the consolidation phase was initiated immediately after a seating phase where a confining pressure less than the desired consolidation stress was applied and the triaxial rod was placed against the load sensor. The rod was locked at all times in this process to prevent any axial load from being applied to the specimen. During the consolidation, a constant isotropic stress was applied and the strain was monitored. Drain valves were open at this stage to allow water to escape as the void ratio reduced. Once the strain vs. time plot had achieved a constant or near constant reading, the consolidation phase was ended, the test moved on to shear.

In accordance with the directions for an isotropic consolidated undrained (CU) test, the drain valves were closed during the shear. A constant shear method was used at which a load was applied to axially strain the specimen at a rate of $3 \%$ per hour. A pressure sensor was placed on one of the drain valves to monitor pore pressure in the specimen. The testing apparatus during the shearing of one of the specimens is shown in Figure 3.23 


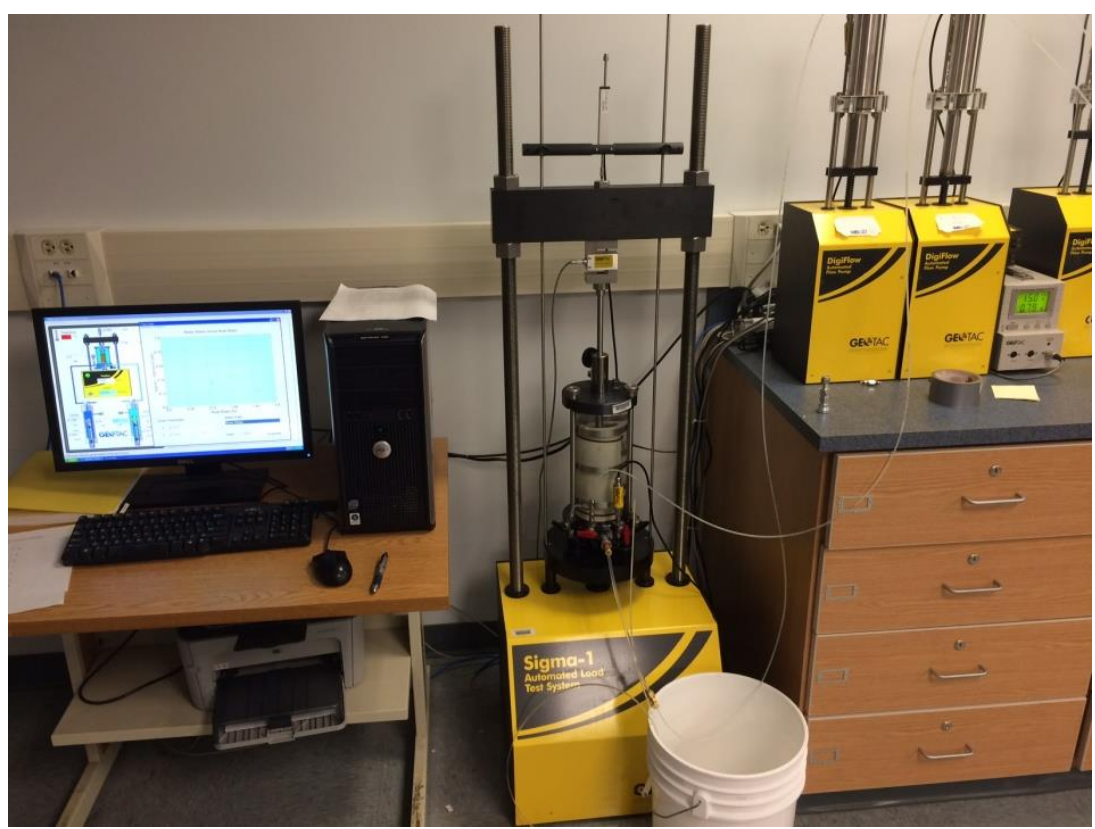

Figure 3.23: Triaxial testing apparatus during shearing of a specimen

All data during the testing was collected electronically and was uploaded to Microsoft Excel for analysis. The output values from the triaxial testing system were converted to the desired stress and strain measurements by a pre-written excel sheet (Russell, 2011).

An analysis of the stress-strain plots provides insight into how the failure occurs within the specimen. This plot is given in Figure 3.24. The failure appears to have occurred at approximately $3 \%$ strain for the ' 2 psi' specimen and 5\% strain for the ' 6 psi' specimen. Little decrease in shear stress is observed between the failure point and the end of testing at $20 \%$ strain. This indicates that there is little change in strength between the peak and residual conditions. 


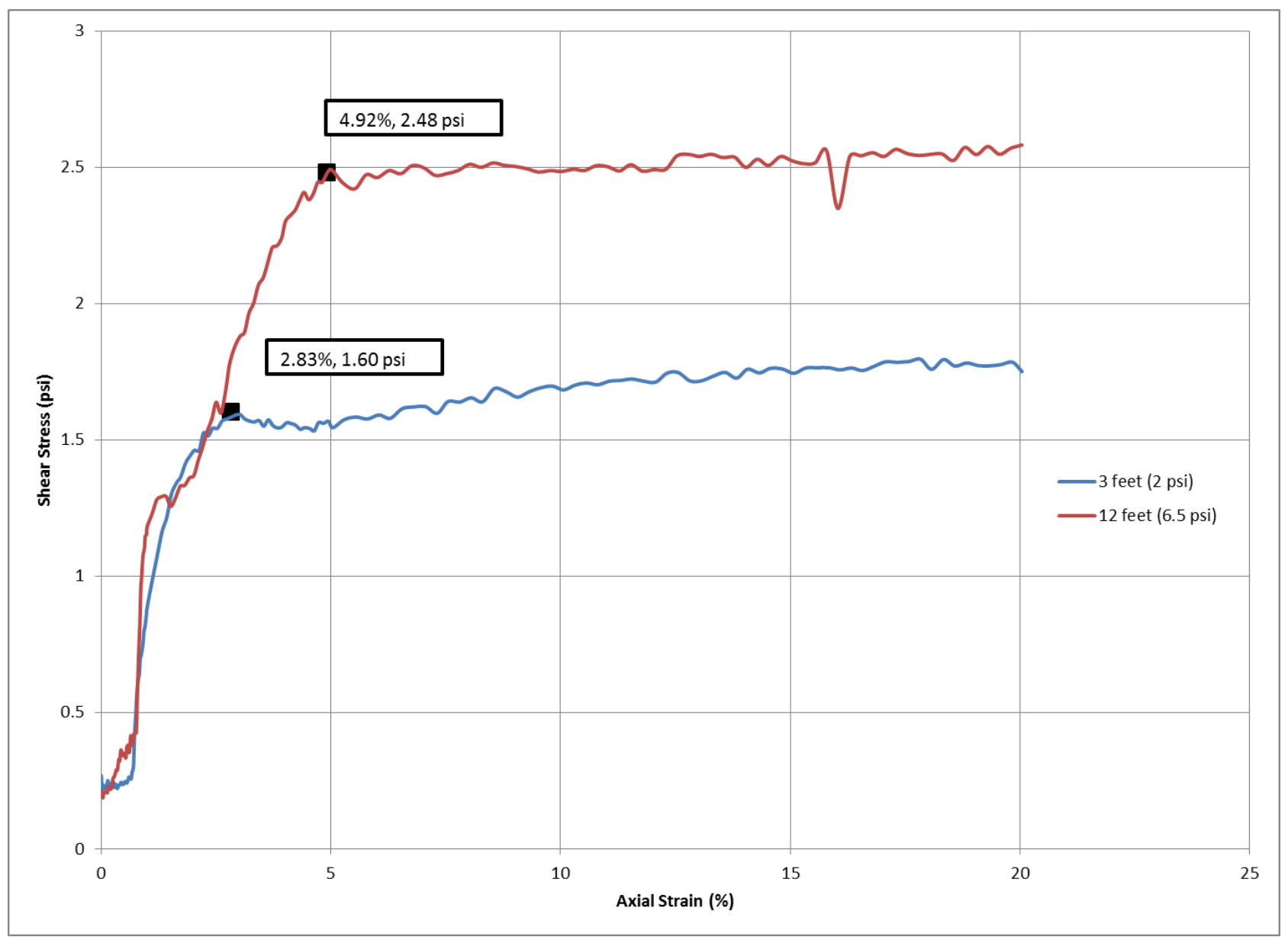

Figure 3.24: Stress Strain Curve from triaxial test of 60/40 blend with failure points noted

To calculate the strength values for the test specimens, the critical figure which had to be created was the p-q plot which shows the stress paths for each specimen during the test. The parameters 'p' and 'q' are defined in Equations 3.1 and 3.2.

$p=\frac{\sigma_{1}{ }^{\prime}+\sigma_{3} \prime}{2}$

$q=\frac{\sigma_{1}^{\prime}-\sigma_{3}^{\prime}}{2}$

Sigma 1 and sigma 3 are the major principle stress and minor principle stress, respectively on a Mohr-Coulomb plot. The p-q plot represents the center and radius of the Mohr circles developed for each test and the conventional Mohr-Coulomb relations, such as the internal angle of friction and cohesion can be determined by the analysis of the $\mathrm{p}-\mathrm{q}$ plot. The $\mathrm{p}-\mathrm{q}$ plot developed for the shale/MGro ${ }^{\mathrm{TM}}$ blend tests and the critical parameters from the plot are given in Figure 3.25. 


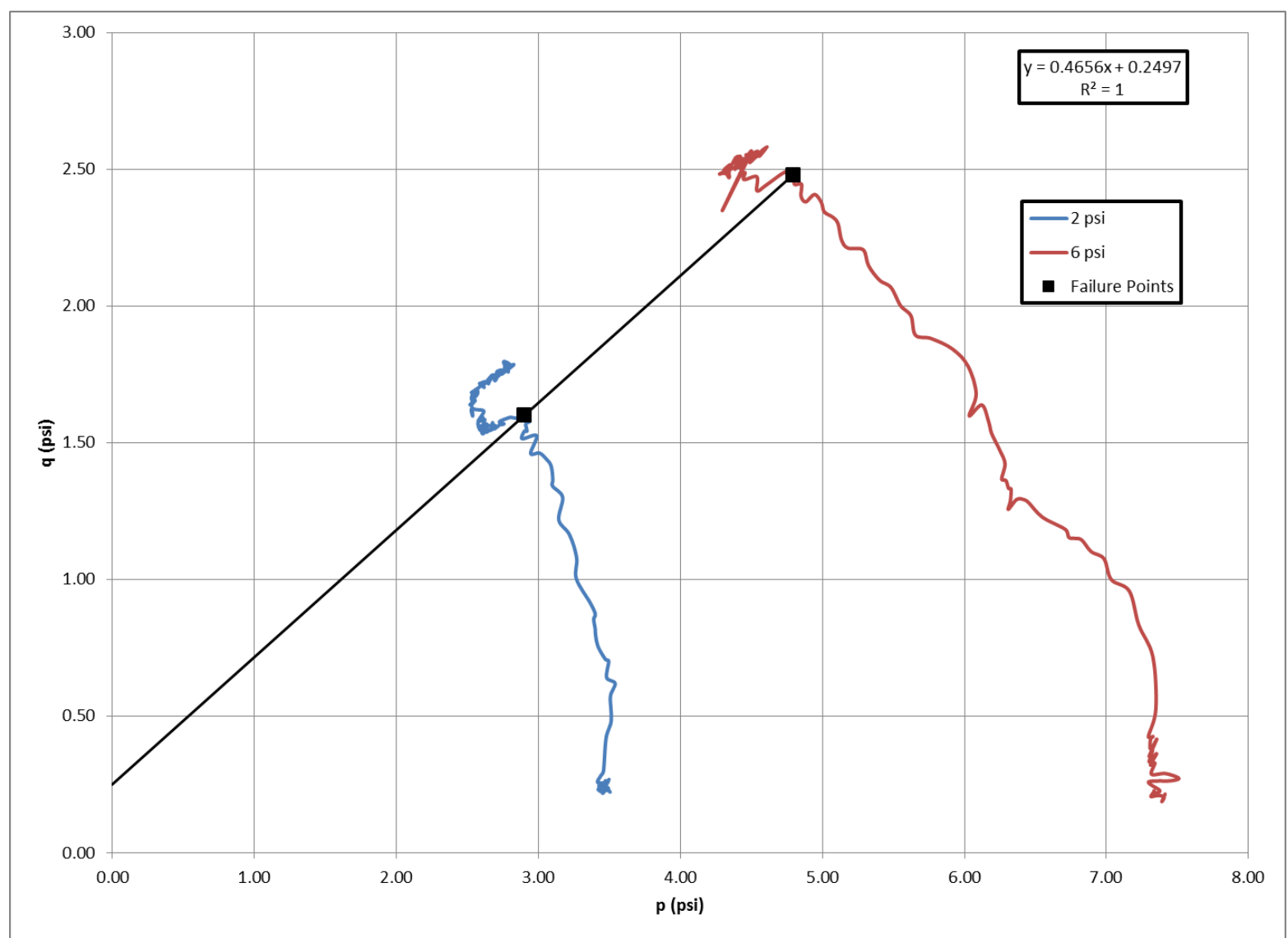

Figure 3.25: p-q plot from triaxial test of 60/40 blend

Failure points were determined for each test as the peak q value prior to each curves jump to the right, which likely occurred at the failure of each specimen. Fitting a best fit line between the two failure points gives a slope value (defined as alpha) and y-intercept value (defined as a'). The alpha angle and a' value are related to the internal angle of friction and cohesion as defined in Equations 3.3 and 3.4.

$\tan \alpha=\sin \phi^{\prime}$

$a^{\prime}=c^{\prime} \cos \phi^{\prime}$

Applying these relationships for the 60/40 blend gives an internal angle of friction of 30.16 degrees and cohesion of $0.279 \mathrm{psi}(1.92 \mathrm{kPa})$. To disregard the effects of cohesion, the yintercept of the line connecting the failure points on the p-q plot can be set to zero. This gives a different alpha angle measurement and a different angle of friction. Completing this process gives an angle of 35.82 degrees.

The failure points identified on the $\mathrm{p}-\mathrm{q}$ diagram were also plotted on the stress-strain diagram (Figure 3.24). Failure occurred at approximately $2.83 \%$ strain for the specimen under a $2 \mathrm{psi}$ confining stress and at $4.92 \%$ for the specimen under the 6.5 psi stress condition. 


\section{4) Summary of Laboratory Testing}

The geotechnical properties of three materials: coarse coal refuse shale, MGro ${ }^{\mathrm{TM}}$ short paper fiber, and blends of these materials were explored in this chapter. The results of these tests are summarized in Table 3.36.

Table 3.36: Summary of Geotechnical testing results

\begin{tabular}{|c|c|c|c|c|}
\hline \multirow[b]{2}{*}{ Geotechnical Property } & \multicolumn{4}{|c|}{ Material } \\
\hline & $\begin{array}{l}\text { Coarse Coal } \\
\text { Refuse Shale }\end{array}$ & MGrotM $^{\mathrm{TM}}$ & $\begin{array}{l}\text { 60/40 Shale- } \\
\text { MGroTM } \\
\text { blend }\end{array}$ & $\begin{array}{c}\text { 80/20 Shale- } \\
\text { MGroTM } \\
\text { blend }\end{array}$ \\
\hline $\begin{array}{c}\text { As received } \mathrm{D}_{10} \text { (\#4 topsize) } \\
(\mathrm{mm})\end{array}$ & $0.525(0.27)$ & $\begin{array}{l}0.975 \\
(0.85)\end{array}$ & $(0.30)$ & $(0.30)$ \\
\hline $\begin{array}{c}\text { As received } \mathrm{D}_{25} \text { (\#4 topsize) } \\
(\mathrm{mm})\end{array}$ & $1.35(0.70)$ & $1.8(1.4)$ & $(0.85)$ & $(0.75)$ \\
\hline $\begin{array}{c}\text { As received } \mathrm{D}_{30}(\# 4 \text { topsize }) \\
(\mathbf{m m})\end{array}$ & $1.73(0.90)$ & $2.05(1.6)$ & $(0.99)$ & $(0.90)$ \\
\hline $\begin{array}{c}\text { As received } \mathrm{D}_{50}(\# 4 \text { topsize) } \\
(\mathrm{mm})\end{array}$ & $4.33(1.5)$ & $3.35(2.2)$ & $(1.7)$ & (1.6) \\
\hline $\begin{array}{c}\text { As received } \mathrm{D}_{60}(\# 4 \text { topsize) } \\
(\mathrm{mm})\end{array}$ & $6.85(1.9)$ & $4.2(2.6)$ & (1.9) & $(2.1)$ \\
\hline $\begin{array}{c}\text { As received } \mathrm{D}_{90}(\# 4 \text { topsize }) \\
(\mathrm{mm})\end{array}$ & $>18(3.9)$ & $9.5(4.1)$ & (3.9) & (3.9) \\
\hline \% Fines (passing No. 200 sieve) & 0.16 & 0.42 & 2.96 & 2.75 \\
\hline Uniformity coefficient, $C_{u}$ & 7.8 & 12.93 & 6.33 & 7.00 \\
\hline Coefficient of Gradation, $\mathrm{C}_{\mathrm{c}}$ & 1.04 & 0.84 & 1.72 & 1.29 \\
\hline Specific Gravity $\mathbf{G}_{\mathrm{s}}$ & 2.19 & $1.92-2.21$ & \multirow{4}{*}{ Not tested } & \multirow{4}{*}{ Not tested } \\
\hline Plastic Limit & 26.1 & \multirow{3}{*}{$\begin{array}{c}\text { Not } \\
\text { tested }\end{array}$} & & \\
\hline Liquid Limit & 30.1 & & & \\
\hline Plasticity Index & 4 & & & \\
\hline $\begin{array}{l}\text { Maximum dry unit weight, } \\
\gamma_{\mathrm{dmax}}\left(\mathbf{k N} / \mathbf{m}^{3}\right)\end{array}$ & $14.6-16.0$ & 8.0 & 11.7 & 13.0 \\
\hline $\begin{array}{c}\text { Optimum moisture content, } \omega_{\text {opt }} \\
(\%)\end{array}$ & $12.3-17.5$ & 63.0 & 28.0 & 19.0 \\
\hline $\begin{array}{c}\text { Saturated Hydraulic } \\
\text { conductivity } k_{\text {sat }}(\mathbf{c m} / \mathbf{s})\end{array}$ & $\begin{array}{l}3.5 \times 10^{-7}- \\
4.22 \times 10^{-4}\end{array}$ & \multirow{4}{*}{$\begin{array}{l}\text { Not } \\
\text { tested }\end{array}$} & $8.61 \times 10^{-4}$ & \multirow{4}{*}{ Not tested } \\
\hline $\begin{array}{l}\text { Effective Angle of Internal } \\
\text { Friction } \varphi^{\prime} \text { (degrees) }\end{array}$ & $41.4-43.8$ & & 30.16 & \\
\hline Effective Cohesion, c' (kPa) & $16.99-25.6$ & & 1.92 & \\
\hline $\begin{array}{l}\text { Effective cohesionless angle of } \\
\text { internal friction, } \varphi^{\prime} c^{\prime}=0 \text { (degrees) }\end{array}$ & $43.21-44.96$ & & 35.82 & \\
\hline
\end{tabular}


Several observations were made from the laboratory testing:

- The observed effective friction angles for the shale material were very high and outside of normal ranges reported by literature (see section 3.1.)

- The hydraulic conductivity value for the shale material was very low, especially at high compaction energies. This was attributed to the creation of fine particles $(<0.074 \mathrm{~mm})$ during compaction. While post-permeability grain size testing was unable to quantify fines creation due to the aggregation of particles after drying, an increase in cohesion was observed during direct shear testing of compacted samples which implies a larger number of fine particles.

- As more $\mathrm{MGro}^{\mathrm{TM}}$ paper fiber is added to the shale material, the maximum dry unit weight decreased and the optimum moisture content increased.

- The Shale/MGro ${ }^{\mathrm{TM}}$ blends have grain size distributions that more closely replicate the shale distribution compared to the $\mathrm{MGro}^{\mathrm{TM}}$ distribution

- The $60 / 40$ Shale/MGro ${ }^{\mathrm{TM}}$ blend was tested for hydraulic conductivity at a low compaction. Based on the observed behavior of the material during compaction testing, the hydraulic conductivity will be lower when more compaction effort is applied to the material.

Results indicated that the materials tested in the geotechnical laboratory could make an effective cap and cover system. The coarse coal refuse was indicated to be a strong material, capable of forming a stable structure. Additionally, the material achieved a low hydraulic conductivity when compacted to Standard Proctor effort or greater. When $\mathrm{MGro}^{\mathrm{TM}}$ short paper fiber was blended with the refuse, a material proven in literature of establishing vegetative growth was added. In a $60 \%$ refuse/ $40 \% \mathrm{MGro}^{\mathrm{TM}}$ volumetric ratio, the material was shown to maintain a friction angle of approximately 30 degrees. This layer, with its potential to establish vegetative growth and high friction angle, could form an effective growth layer. 


\section{4) DESIGN AND MODELING OF CAP AND COVER SYSTEM}

\section{1) General Design}

The cap and cover system was designed meet similar criteria to the United States Environmental Protection Agency and West Virginia Department of Environmental Protection landfill cover systems. The performance objectives of the cap and cover included:

4. Reduce infiltration of rainfall over the coal refuse fill

5. Capture infiltration that does occur and keep it from entering fill

6. Facilitate growth of vegetation on outer surface

7. Be geotechnically stable

To accomplish these goals, a three layer design is proposed. The layers, their function, and construction materials are summarized in section 4.1.1-4.1.3. Figure 4.1 shows a cross-section of the proposed cover design.

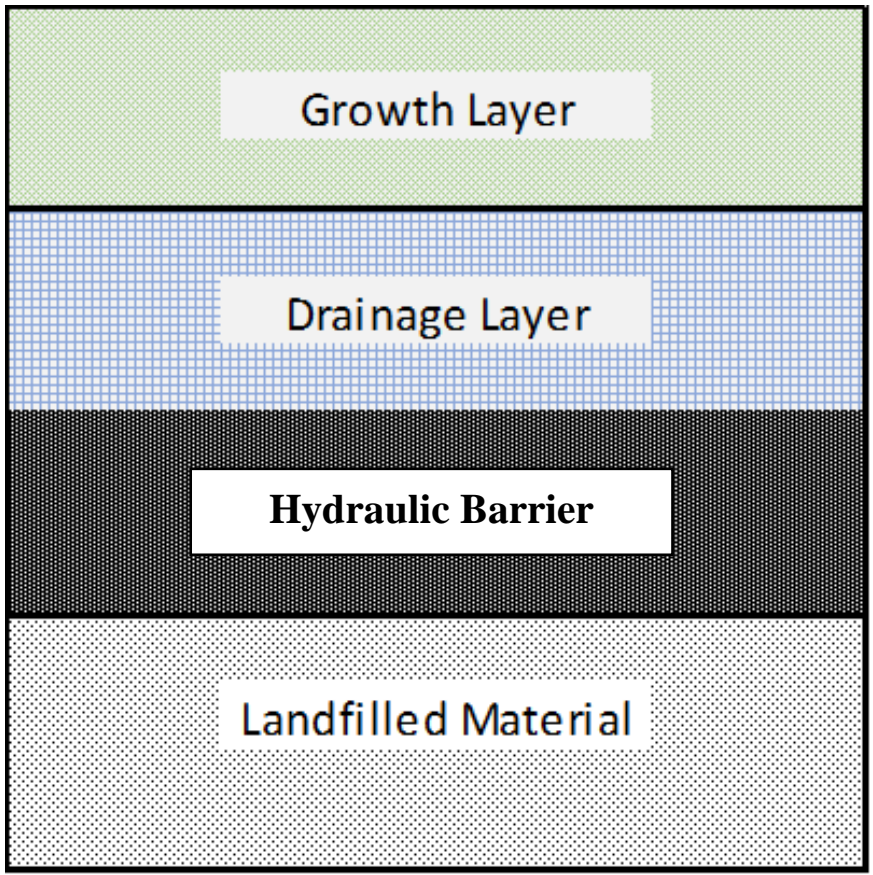

Figure 4.1: Proposed Cap and Cover design layers

\subsection{1) Growth Layer}

The growth layer will be composed of the $60 / 40$ shale/MGro ${ }^{\mathrm{TM}}$ blend described in section 3.3.3.2. This layer will primarily serve as medium upon which to establish growth of grasses and other vegetation. As explained in Section 2.3, paper mill sludges have been proven as an effective soil amendment for mining reclamation projects and offer the capability to raise the soil $\mathrm{pH}$, which will be essential when blending with the acidic coal refuse. 


\subsection{2) Drainage Layer}

The drainage layer will be placed directly under the growth layer and above the hydraulic barrier layer. This layer will be composed of loose coarse coal refuse material $\left(\gamma_{\mathrm{d}}=14-15 \mathrm{kN} / \mathrm{m}^{3}\right)$ from Royal Scot site with a small amount of limestone additive to counter production of acidic water. The purpose of this layer will be to capture water which has permeated through the growth layer and control seepage within the cover system. The drainage layer will be exposed to the surface in the on-site stream valleys so that water can exit at these locations.

\subsection{3) Hydraulic barrier layer}

The hydraulic barrier layer will serve as the final barrier between precipitation infiltration and bulk of the AMD-generating coarse coal refuse. This layer will be constructed from a heavily compacted layer of the refuse material, which has been demonstrated to achieve low hydraulic conductivities laboratory testing (see section 3.1.6). While the field achieved field values are unlikely to achieve the values near $10^{-7} \mathrm{~cm} / \mathrm{s}$ observed in the laboratory, heavily compacting the shale can still create a material with a very low hydraulic conductivity. With the hydraulic barrier layer in place, a majority of groundwater movement in the reclaimed Royal Scot refuse pile should be confined to the surface layers, minimizing the contact of the coarse coal refuse fill with two of the critical ingredients for acid-mine drainage generation: water and oxygen.

\section{2) Model Input Parameters}

As discussed in Chapter 3, a soil testing program for the materials to be used in the Royal Scot Reclamation project was completed. The results of the soil testing provided the basic geotechnical properties, strength parameters, and hydraulic properties for these materials. The average properties from the soil testing for required model inputs for the materials in the cap and cover system are summarized in Table 4.1.

Table 4.1: Average properties for cap and cover materials from laboratory testing

\begin{tabular}{|c|c|c|c|c|c|}
\hline \multirow{3}{*}{ Material } & Moist Unit Weight & \begin{tabular}{|c|}
$\begin{array}{c}\text { Effective Internal Angle } \\
\text { of Friction }\end{array}$ \\
\end{tabular} & Effective Cohesion & Hydraulic Conductivity & \multirow[t]{2}{*}{ Porosity } \\
\hline & $\mathrm{kN} / \mathrm{m}^{3}$ & degrees & $\mathrm{kPa}$ & $\mathrm{cm} / \mathrm{s}$ & \\
\hline & $V_{\mathrm{m}}$ & $\phi^{\prime}$ & $c^{\prime}$ & $k$ & $n$ \\
\hline \begin{tabular}{|c} 
Shale (loose compaction- 11\% Proctor- \\
$67.85 \mathrm{~kJ} / \mathrm{m}^{3}$ ) \\
\end{tabular} & 17.16 & 43.83 & 14.46 & 4.00E-04 & 0.45 \\
\hline $\begin{array}{l}\text { Shale (optimal compaction- Standard } \\
\text { Proctor } 592.5 \mathrm{~kJ} / \mathrm{m}^{3} \text { ) }\end{array}$ & 18.80 & 41.40 & 25.60 & $2.00 \mathrm{E}-07$ & 0.27 \\
\hline $60 \%$ Shale $/ 40 \%$ Mgro blend & 12.72 & 31.98 & 1.92 & $1.00 \mathrm{E}-03$ & 0.53 \\
\hline
\end{tabular}

\subsection{1) Input Ranges}

Variation in the geotechnical properties of the soils is expected at the Royal Scot project and using only the laboratory average value would not be sufficient to obtain a representative model. This variation was observed in section 3.1.6 where compaction molds were completed for direct shear testing. Despite using an identical testing method, differences of $12-17 \%$ (as seen in Table 3.23) were observed between the achieved and target compaction densities. This variation was attributed to the materials used for these tests being collected in slightly different locations. 
To determine a range of values for the parameters, a standard deviation was required. As a large number of tests are required to obtain a representative standard deviation value, the coefficient of variation (COV) method described in Duncan (2000) was used. Duncan (2000) provides a range of published COV values for various geotechnical properties. This range was then averaged to obtain a single COV value for calculations. The COV was then multiplied by the lab average to obtain the standard deviation (equation 4.1).

$$
\sigma=(V)(\bar{x})
$$

Where:

$\sigma=$ standard deviation

$\mathrm{V}=$ Coefficient of variation

$\bar{x}=$ lab average

Ranges for the unit weights and internal angle of friction were determined by adding and subtracting two standard deviations from the laboratory averages as summarized in Table 4.2. The data was assumed to be normally distributed and the two-standard deviation range above and below the mean would capture approximately $95 \%$ of possible values.

Two standard deviations above the average internal angle of friction yielded friction angles in excess of 45 degrees. These numbers were unrealistic and outside of the range which could be modeled by computer programs, so the maximum possible friction angle was set equal to the largest which could be modeled, 45 degrees.

Table 4.2: Calculated standard deviations and range of values within 2 standard deviations of the mean

\begin{tabular}{|c|c|c|c|c|}
\hline \multirow{2}{*}{ Material } & \multicolumn{2}{|c|}{ Moist Unit Weight, $\gamma_{\mathrm{m}}$} & \multicolumn{2}{c|}{ Effective Internal Angle of Friction, $\phi^{\prime}$} \\
\cline { 2 - 5 } & $\begin{array}{c}\text { Calculated } \\
\text { standard deviation }\end{array}$ & Range of values & $\begin{array}{c}\text { Calculated standard } \\
\text { deviation }\end{array}$ & Range of values \\
\cline { 2 - 5 } & $\mathrm{kN} / \mathrm{m}^{3}$ & $\mathrm{kN} / \mathrm{m}^{3}$ & degrees & degrees \\
\hline $\begin{array}{c}\text { Shale (loose compaction- 11\% Proctor- } \\
67.85 \mathrm{~kJ} / \mathrm{m}^{3} \text { ) }\end{array}$ & 0.86 & $15.54-18.88$ & 3.29 & $37.29-50.4$ \\
\hline $\begin{array}{c}\text { Shale (optimal compaction- Standard } \\
\text { Proctor } 592.5 \mathrm{~kJ} / \mathrm{m}^{3} \text { ) }\end{array}$ & 0.94 & $16.92-20.68$ & 3.11 & $35.19-47.61$ \\
\hline $60 \%$ Shale $/ 40 \%$ Mgro blend & 0.64 & $11.45-13.99$ & 2.4 & $27.18-36.78$ \\
\hline
\end{tabular}

An additional strength parameter, cohesion, is required for stability modeling. As shown in section 3.1.8, the laboratory values for cohesion for the shale are near the highest shown in literature. Additionally, with the high moisture contents anticipated in the surface growth layer with the $\mathrm{MGro}^{\mathrm{TM}}$ paper fiber and the sandy nature of the coarse coal refuse, cohesion is not expected to be significant in the final design. Therefore a range of values from $0 \mathrm{kPa}$ to $8 \mathrm{kPa}$, much smaller than the laboratory averages, was evaluated for shale. As the laboratory average value of cohesion for the growth layer was much lower than that of the shale, a smaller range of values was tested, from 0 to $4 \mathrm{kPa}$. The cohesion variation for the materials is summarized in Table 4.3. 
Table 4.3: Cohesion values tested for sensitivity analysis

\begin{tabular}{|c|c|c|}
\hline $\begin{array}{c}\text { Value } \\
\text { range }\end{array}$ & $\begin{array}{c}\text { Cohesion for } \\
\text { Shale } \\
(\mathbf{k P a})\end{array}$ & $\begin{array}{c}\text { Cohesion for } \\
\mathbf{6 0 / 4 0} \text { blend } \\
\mathbf{( k P a})\end{array}$ \\
\hline Lowest & 0 & 0 \\
\hline Low & 2 & 1 \\
\hline Medium & 4 & 2 \\
\hline High & 6 & 3 \\
\hline Highest & 8 & 4 \\
\hline
\end{tabular}

Hydraulic conductivity was not varied in this stage of modeling. Its analysis was completed in section 4.4.3.

\subsection{2) Sensitivity Analysis}

A sensitivity analysis was completed to evaluate the impact of the model input parameters on the expected stability of a slope composed of the cap and cover system. A baseline 2 horizontal to 1 (2H:1V or 26.6 degrees) vertical slope was constructed in the SVSlope ${ }^{\mathrm{TM}}$ program with a vertical height of 50 feet $(15.24 \mathrm{~m})$. A baseline cap and cover was placed on the slope with a growth layer of 3 feet (0.914), drainage layer of 3 feet (0.914) and a hydraulic barrier layer of 5 feet (1.524). Then, the model was solved by varying the input parameters for stability: moist unit weight, internal angle of friction, and cohesion. While holding the other parameters constant at their average (and lowest cohesion for models not changing this value), the value for the property being evaluated was changed for each material. Tests were run for values at the laboratory averages, as well as one and two standard deviations above and below the average using the range of values shown in Table 4.2. A minimum Factor of Safety (FOS) was determined for each model. Results for the analysis are summarized in Table 4.4 through Table 4.6.

Table 4.4: Results of moist unit variation

\begin{tabular}{|c|c|}
\hline \multicolumn{2}{|c|}{ Property: Moist Unit Wt. } \\
\hline Values & Min. FOS \\
\hline -2 STDEV & 1.22 \\
\hline -1 STDEV & 1.22 \\
\hline Average & 1.22 \\
\hline +1 STDEV & 1.22 \\
\hline +2 STDEV & 1.22 \\
\hline
\end{tabular}


Table 4.5: Results of friction angle variation

\begin{tabular}{|c|c|}
\hline \multicolumn{2}{|c|}{ Property: Friction angle } \\
\hline Values & Min. FOS \\
\hline -2 STDEV & 1.01 \\
\hline -1 STDEV & 1.12 \\
\hline Average & 1.22 \\
\hline+1 STDEV & 1.33 \\
\hline+2 STDEV & 1.45 \\
\hline
\end{tabular}

Table 4.6: Results of cohesion variation

\begin{tabular}{|c|c|}
\hline \multicolumn{2}{|c|}{ Property: Cohesion } \\
\hline Values & Min. FOS \\
\hline Lowest & 1.22 \\
\hline Low & 1.61 \\
\hline Medium & 1.98 \\
\hline High & 2.35 \\
\hline Highest & 2.67 \\
\hline
\end{tabular}

Sensitivity analysis of stability showed that cohesion was the input parameter with the greatest impact on the factor of safety. An increase from zero to the lowest values results in an FOS increase of approximately 0.4 and takes the slope from not satisfying the minimum FOS value of 1.5 required by the West Virginia DEP to exceeding this value.

The slope stability was moderately sensitive to the friction angle over the two-standard deviation range. The stability value was not affected at all by changing the moist unit weight for all materials.

Figure 4.2 shows the slope stability model results using the laboratory average values with the failure surfaces with a factor of safety value less than 1.5 shown in red. Each of these surfaces remains within the surface growth layer, indicating that this zone will be critical to the overall stability of the design. The toe of the slope is cut for the geometry's future use in seepage modeling so that a water flow-path area is allowed. 


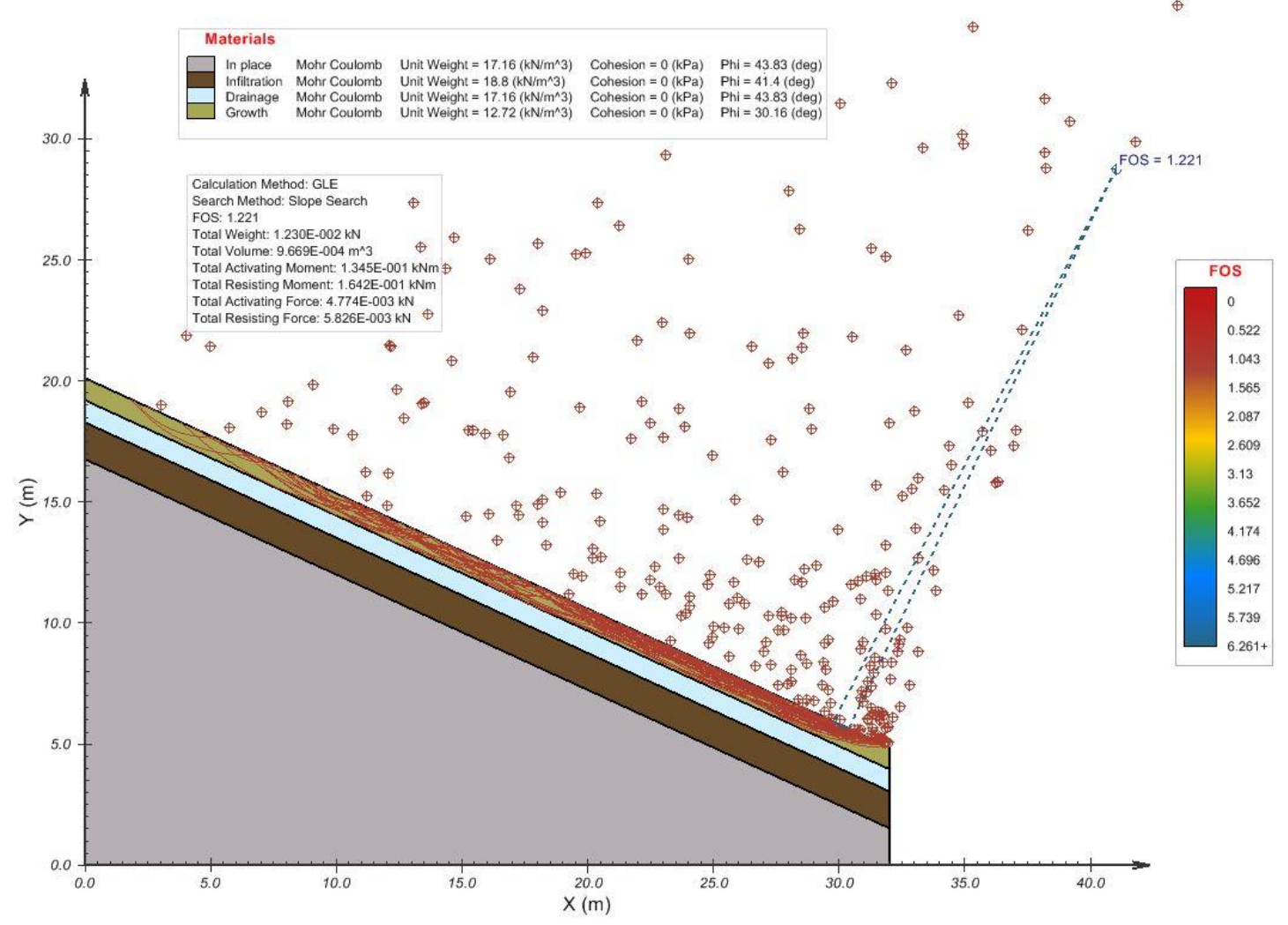

Figure 4.2: 2:1 slope used for sensitivity analysis with average properties and zero cohesion

\subsection{3) Selection of properties for models}

Following the results of the sensitivity analysis and initial modeling, a set of material properties was determined for use in the future models. These parameters were selected to sit slightly below the average stability and to fall closer to literature values and are shown in Table 4.7. A moist unit weight one standard deviation over the average and internal angle of friction one standard deviation below the average were selected. The cohesion was set to the low values for each material: $2 \mathrm{kPa}$ for shale and $1 \mathrm{kPa}$ for the $60 / 40 \mathrm{blend}$.

Table 4.7: Material properties selected for modeling

\begin{tabular}{|c|c|c|c|}
\hline \multirow{2}{*}{ Material } & Moist Unit Weight & Internal Angle of Friction & Cohesion \\
\cline { 2 - 4 } & $\mathrm{kN} / \mathrm{m}^{3}$ & degrees & $\mathrm{kPa}$ \\
\hline Shale (loose compaction- 11\% Proctor- $67.85 \mathrm{~kJ} / \mathrm{m}^{3}$ ) & 18.02 & 40.54 & 2.00 \\
\hline Shale (optimal compaction- Standard Proctor $592.5 \mathrm{~kJ} / \mathrm{m}^{3}$ ) & 19.74 & 38.30 & 2.00 \\
\hline $60 \%$ Shale/40\% Mgro blend & 13.36 & 27.90 & 1.00 \\
\hline
\end{tabular}




\section{3) Stability Modeling}

The selected material properties were applied to the $2 \mathrm{H}: 1 \mathrm{~V}$ slope and stability analysis in SVSlope ${ }^{\mathrm{TM}}$ using the GLE calculation method was completed. A minimum factor of safety value of 1.48 was calculated for the model. Figure 4.3 shows the results from this model. Again, all failure planes with a FOS value of less than 1.5 (shown in red) were located in the growth layer composed of the $60 / 40$ Shale/MGro ${ }^{\mathrm{TM}}$ blend.

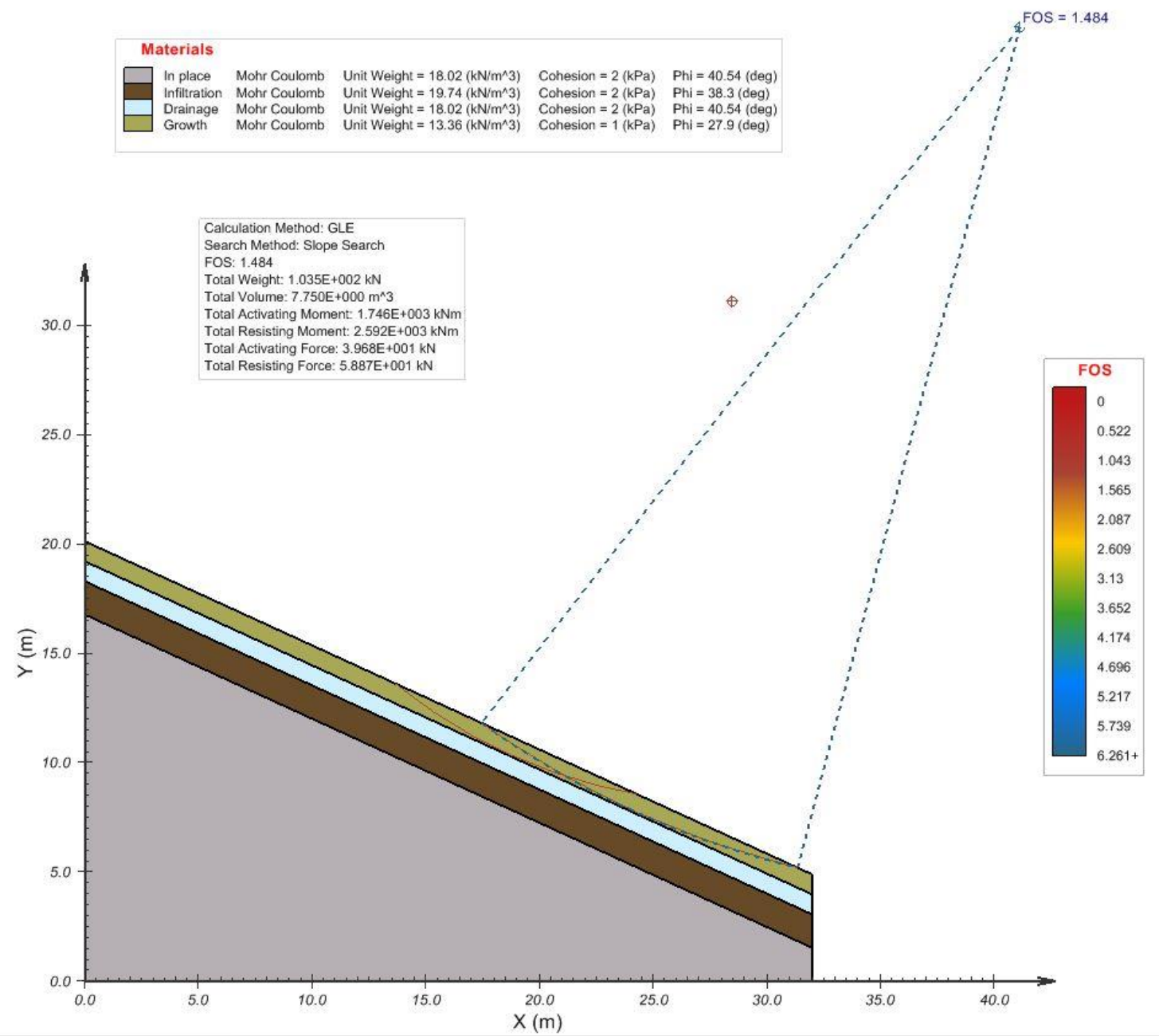

Figure 4.3: Stability modeling results for cover on 2:1 slope with selected properties

With the selected material properties, the $2 \mathrm{H}: 1 \mathrm{~V}$ slope does not meet the minimum 1.5 factor of safety required by the West Virginia DEP for slope stability. To evaluate the impact of slope on the FOS value, a similar slope was constructed at a $2.5 \mathrm{H}$ to $1 \mathrm{~V}$ ratio. The horizontal length was held the same to the $2: 1$ slope at 100 feet $(30.48 \mathrm{~m})$ which set the elevation rise to 40 feet $(12.19 \mathrm{~m})$. Evaluating this model with the selected material properties gives a factor of safety value of 1.856. The model results are shown in Figure 4.4. Given that the calculated factor of safety exceeded the required minimum of 1.5 , the $2.5 \mathrm{H}: 1 \mathrm{~V}$ slope was determined to be stable for use in modeling seepage through the cover system and as a basis for the geomorphic designs. 


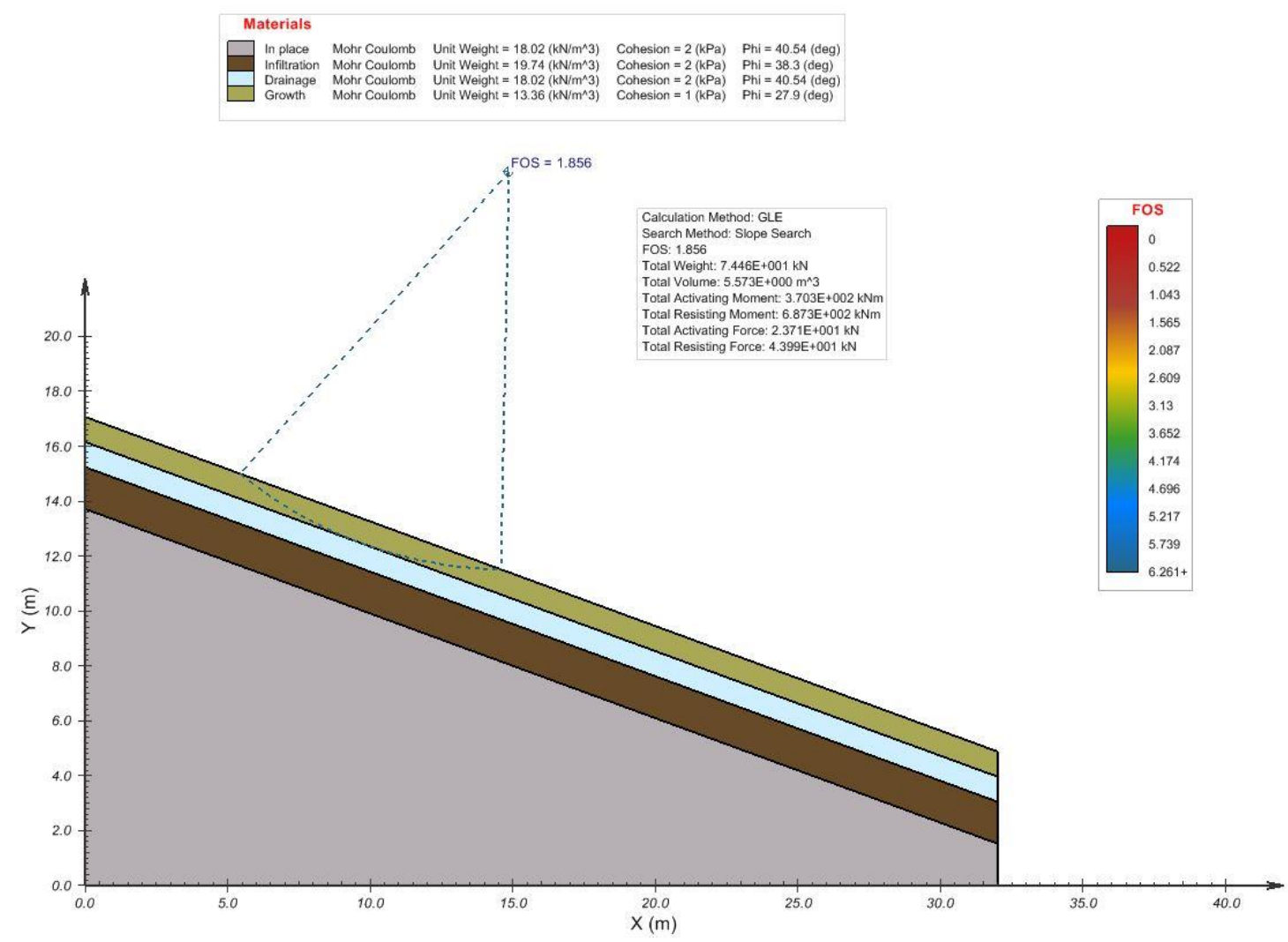

Figure 4.4: 2.5 to 1 slope with base cover design and selected properties

\section{4) Seepage Performance Modeling}

The primary objective of the cap and cover system is to quickly remove any infiltrated precipitation which has infiltrated the outer growth layer and prevent it from entering the main fill where it will combine with the coal refuse to form acidic compounds. In this design, the hydraulic barrier layer will prevent infiltration from entering the fill and the drainage layer will control all of the seepage above this layer and quickly remove it from the slope.

Key parameters in the design of the hydraulic barrier layer are its thickness and hydraulic conductivity. The layer must be constructed thick enough with a low enough hydraulic conductivity such that it prevents water from infiltrating beyond the drainage layer and into the refuse fill.

To evaluate the performance of the hydraulic barrier layer of the cap and cover system, seepage modeling was performed in SVFlux ${ }^{\mathrm{TM}}$. A constant infiltration rate was placed into the cover over a two-year period and the cumulative water flow exiting each region was measured across flux lines at the toe of the slope. The performance of the cover was evaluated based on a comparison of the percentage of total flow exiting above the hydraulic barrier layer to the flow exiting in the fill below the layer. 


\subsection{1) Calculation of Infiltration Rate}

The average infiltration into the fill was calculated based on average rainfall at the nearby town of Rupert, West Virginia. The total average annual precipitation of 53.14 inches $(134.98 \mathrm{~cm})$ based on 1981-2010 normals (U.S Climate Data, 2016) was converted to an average daily rate $(0.00370 \mathrm{~m} / \mathrm{d})$. As stated in DePriest (2015), significant variation can occur in the infiltration rates on reclaimed slopes. Therefore, as in that study, a simplified method was used for the modeling. Infiltration into the fill was assumed to be $55 \%$ of the total precipitation $(0.00204 \mathrm{~m} / \mathrm{d})$ which will be applied uniformly over the slope for the model time duration. This rate is very similar to the rate applied by DePriest (2015) for a site also located in southern West Virginia.

\subsection{2) Unsaturated hydraulic conductivity}

It is anticipated that much of the soil within the compacted hydraulic barrier layer and the underlying refuse fill will not exist in a saturated condition like the growth and drainage layers. Therefore, unsaturated hydraulic conductivity calculations were required for these layers in the modeling.

Unsaturated soil property functions were determined using the Fredlund and Xing (1994) equation for the Soil-Water Characteristic Curve (SWCC) (Equation 4.2):

$$
\theta(\psi)=\left(1-\frac{\ln \left(1+\frac{\psi}{\psi_{r}}\right)}{\ln \left(1+\frac{100000}{\psi_{r}}\right)}\right) \theta_{S}\left(\frac{1}{\left(\ln \left[e+\left(\frac{\psi}{a}\right)^{n}\right]\right)^{m}}\right)
$$

where,

$\theta=$ volumetric water content $(\%)$

$\psi=$ matric suction $(\mathrm{kPa})$

$\psi_{r}=$ matric suction corresponding to residual water content $=\mathrm{h}_{\mathrm{r}}(\mathrm{kPa})$

$\theta_{s}=$ saturated volumetric water content (\%)

$e=$ natural number, 2.71828

$a, n, m, h_{r}:$ curve fitting parameters

Saturated volumetric water content was assumed to be equal to the porosity for each material (see Table 4.1). Empirically developed fitting parameters a, $\mathrm{n}, \mathrm{m}$, and $\mathrm{h}_{\mathrm{r}}$ were estimated using the Torres (2011) model for granular materials (Equations 4.3-4.6) using laboratory data on grain size distribution of the shale fill material. The $\mathrm{D}_{10}$ of the shale material of $0.30 \mathrm{~mm}$ resulted in the equations yielding unreasonable values meaning that the equation was not applicable for materials present at the Royal Scot site. A quick search of additional methods also yielded an acceptable material top size smaller than $0.30 \mathrm{~mm}$. Therefore, the Torres (2011) equations were applied using a material $\mathrm{D}_{10}$ of $0.11 \mathrm{~mm}$, near the maximum size that can be applied. This particle size yielded the following fitting parameters: $a=9.62, \mathrm{n}=4.72, \mathrm{~m}=0.79$, and $\mathrm{h}_{\mathrm{r}}=100$. Parameter " $\mathrm{a}$ " was related to and approximately the air entry value; " $n$ " controlled the slope of the curve at its inflection point; "m" was related to residual water content; "hr" corresponded to matric suction under residual water content conditions (Depriest, 2015). 


$$
\begin{aligned}
& a_{f}=-967.21 * D_{10}^{2}+218.37 * D_{10}-2.7 \\
& n=10^{\left(-0.0075 a_{f}^{3}+0.1133 a_{f}^{2}-0.3577 a_{f}+0.3061\right)} \\
& m=0.0058 a_{f}^{3}-0.0933 a_{f}^{2}+0.4069 a_{f}+0.3481 \\
& h_{r}=100
\end{aligned}
$$

where,

$D_{10}=$ grain size diameter at $10 \%$ passing by weight (mm)

$a_{f}=1.28$ if $D_{10}<0.020 \mathrm{~mm}$

Figure 4.5 shows the generated SWCC curve.

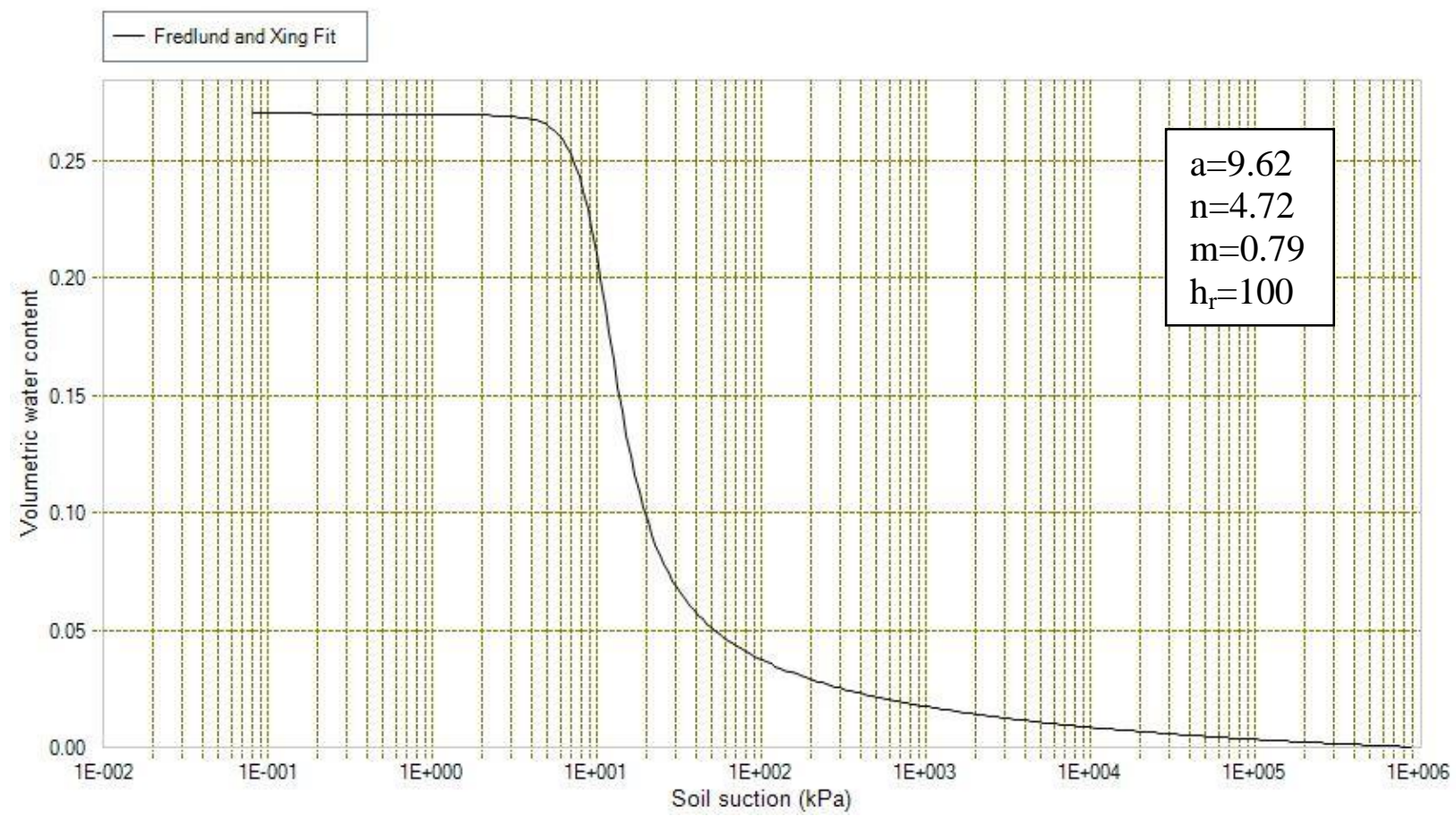

Figure 4.5: Soil-Water Characteristic Curve (SWCC Curve)

The permeability function was estimated according to Fredlund et al. (1994) (Equation 4.7) using the developed SWCC. Integration was performed within the finite element groundwater modeling tool (DePriest, 2015). 


$$
k_{r}(\psi)=\frac{\int_{\ln (\psi)}^{b} \frac{\theta\left(e^{y}\right)-\theta(\psi)}{e^{y}} \theta^{\prime}\left(e^{y}\right) d y}{\int_{\ln \left(\psi_{a e v}\right)}^{b} \frac{\theta\left(e^{y}\right)-\theta_{S}}{e^{y}} \theta^{\prime}\left(e^{y}\right) d y}
$$

where,

$k_{r}(\psi)=$ coefficient of permeability as a function of matric suction

$\psi=$ matric suction $(\mathrm{kPa})$

$b=\ln (1000000)$

$y=$ dummy variable representing the logarithm of integration

$\psi_{\text {aev }}=$ air entry value $(\mathrm{kPa})$

$\theta\left(e^{y}\right)=$ Equation 4.1 as a function of $e^{y}$

$\theta(\psi)=$ equation 4.1 as a function of matrix suction

$\theta^{\prime}\left(e^{y}\right)=$ derivative of equation 4.1 as a function of $e^{y}$

$\theta_{s}=$ satuated volumetric water content (\%)

$e=$ natural number, 2.71828

Figure 4.6 shows the hydraulic conductivity plotted against the soil suction for the $11 \%$ compacted shale. As can be observed, the saturated hydraulic conductivity governs until a soil suction of approximately $7 \mathrm{kPa}$ before falling to a minimum value of approximately $9 \times 10^{-5} \mathrm{~m} / \mathrm{d}$ $\left(1.04 \times 10^{-7} \mathrm{~cm} / \mathrm{s}\right)$. The minimum was arbitrarily set as the curve without a minimum continues to fall to unrealistically low values. This minimum is required for stable calculations in the model.

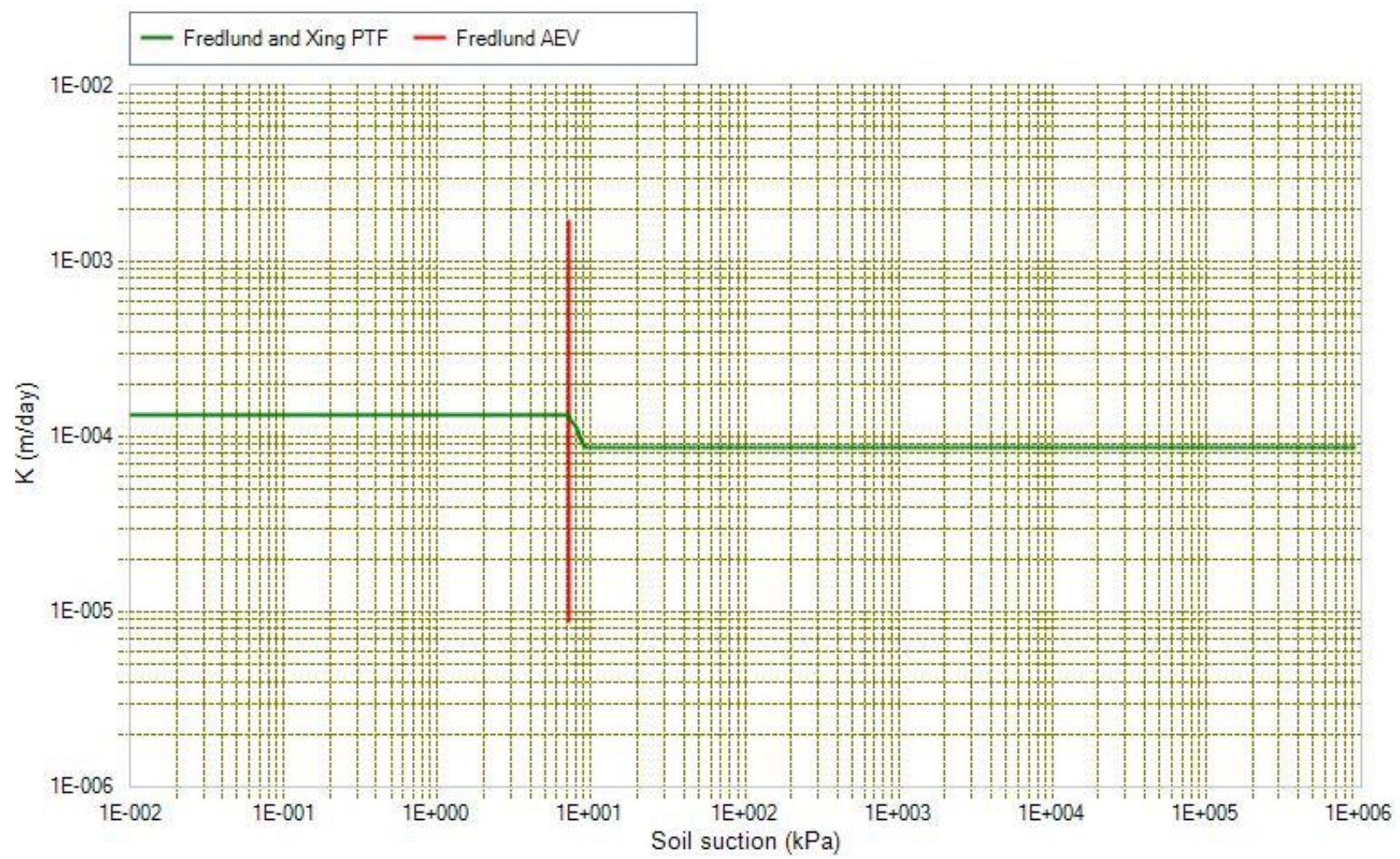

Figure 4.6: Hydraulic conductivity plot 


\subsection{3) Sensitivity analysis from two-year transient model}

Once all of the geotechnical parameters pertaining to seepage modeling were specified, transient models were run using the $2.5 \mathrm{H}$ to $1 \mathrm{~V}$ geometry created in section 4.3 . Two factors were varied in the models: infiltration layer thickness and the hydraulic conductivity of that layer. The purpose of this modeling was to determine the optimal design for the hydraulic barrier layer thickness such that a majority of the infiltration volume does not enter the refuse fill. During the tests, the drainage layer and growth layer thicknesses were held constant at 3 feet $(0.915 \mathrm{~m})$ each.

Three infiltration layer thicknesses were tested: $0.305 \mathrm{~m}, 0.915 \mathrm{~m}$, and $1.525 \mathrm{~m}(1,3$, and 5 feet). For each thickness, the hydraulic conductivity was tested at 3 points. The first point was set and $2 \times 10^{-7} \mathrm{~cm} / \mathrm{s}$, the laboratory value, and the remaining points were set one and two orders of magnitude higher $\left(2 \times 10^{-6}\right.$ and $\left.2 \times 10^{-5} \mathrm{~cm} / \mathrm{s}\right)$. For each test, the model geometry remained constant except for the infiltration layer thickness. The slope was cut off near the toe with review boundaries placed so that flow could exit the model system. Additionally, flux lines were placed at the slope toe for the measurement of flow through each layer. Figure 4.7 shows the model setup for the $5 \mathrm{~m}$ infiltration layer thickness and low hydraulic conductivity.

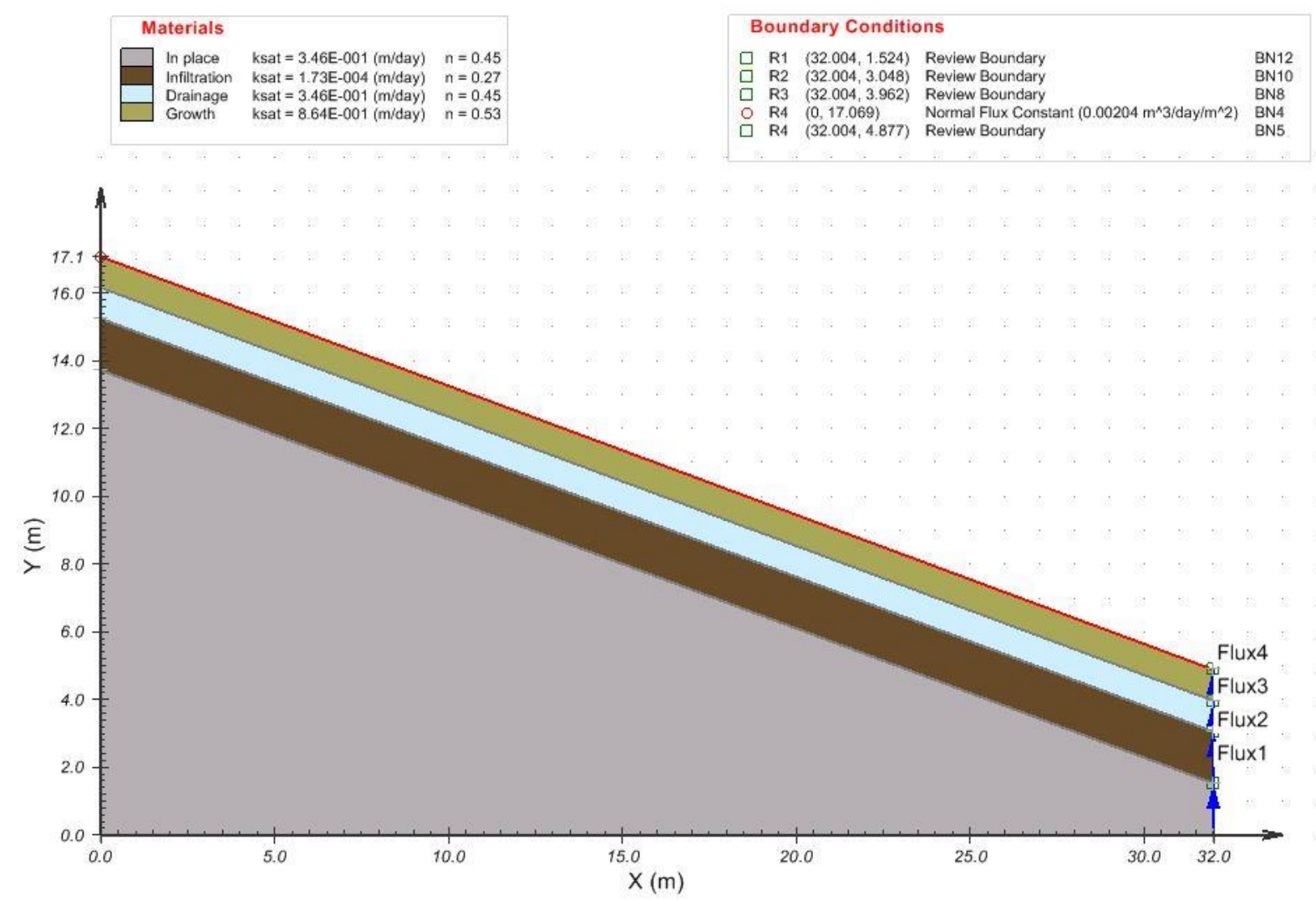

Figure 4.7: 2.5 to 1 slope used in seepage modeling to evaluate cap and cover system

The models were evaluated for the cumulative flow passing through the flux lines in each layer over the two year period. The percentage of the total was calculated and flow above the hydraulic barrier layer (growth and drainage layers) was separated from the flow out of the 
refuse fill. The percentage of flow above the hydraulic barrier layer was the parameter compared among the models.

All of the layer thicknesses are effective at controlling the infiltration when the hydraulic conductivity is set at the lowest value as they keep approximately $90 \%$ of the flow in the drainage and growth layers. The 3 foot and 5 foot layers are also very effective at the medium hydraulic conductivity, keeping over $85 \%$ of the flow above the fill. The 1-foot layer thickness is noticeably less effective at this permeability as the flow drops to $69.6 \%$ above the refuse. None of the layer thicknesses are effective when the hydraulic conductivity is dropped two orders of magnitude to $2 \times 10^{-5} \mathrm{~cm} / \mathrm{s}$ with the 5 foot layer only able to keep $10.3 \%$ of the flow above the fill material.

Since the 5 foot hydraulic barrier was ineffective at the $2 \times 10^{-5} \mathrm{~cm} / \mathrm{s}$ hydraulic conductivity, two additional layer thicknesses 7 feet $(2.134 \mathrm{~m})$ and 10 feet $(3.048 \mathrm{~m})$ were tested. Tests on these thicknesses were only conducted at the high hydraulic conductivity. The seven and ten foot layers were able to keep approximately 11.6 and 19.4\%, respectively, of flow above the fill material. The full results of the seepage modeling are given in Table 4.8. Table 4.9 shows the system for the decision on whether a cover system was effective.

Table 4.8: Seepage modeling results to evaluate effect of thickness and hydraulic conductivity changes in hydraulic barrier layer

\begin{tabular}{|c|c|c|c|}
\hline \multicolumn{2}{|c|}{ Model Condition } & \multirow{2}{*}{$\begin{array}{l}\text { Percentage of } \\
\text { flow above } \\
\text { hydraulic barrier }\end{array}$} & \multirow{2}{*}{ Decision } \\
\hline Infiltration Layer Thickness & Hydraulic Conductivity & & \\
\hline \multirow{3}{*}{$1 \mathrm{ft}(0.305 \mathrm{~m})$} & Low $2 \times 10^{-7} \mathrm{~cm} / \mathrm{s}$ & $87.67 \%$ & Effective \\
\hline & Medium $2 \times 10^{-6} \mathrm{~cm} / \mathrm{s}$ & $69.62 \%$ & Mostly Effective \\
\hline & High $2 \times 10^{-5} \mathrm{~cm} / \mathrm{s}$ & $4.28 \%$ & Not effective \\
\hline \multirow{3}{*}{$3 \mathrm{ft}(0.915 \mathrm{~m})$} & Low $2 \times 10^{-7} \mathrm{~cm} / \mathrm{s}$ & $92.68 \%$ & Effective \\
\hline & Medium $2 \times 10^{-6} \mathrm{~cm} / \mathrm{s}$ & $85.46 \%$ & Effective \\
\hline & High $2 \times 10^{-5} \mathrm{~cm} / \mathrm{s}$ & $6.56 \%$ & Not effective \\
\hline \multirow{3}{*}{$5 \mathrm{ft}(1.525 \mathrm{~m})$} & Low $2 \times 10^{-7} \mathrm{~cm} / \mathrm{s}$ & $92.40 \%$ & Effective \\
\hline & Medium $2 \times 10^{-6} \mathrm{~cm} / \mathrm{s}$ & $89.60 \%$ & Effective \\
\hline & High $2 \times 10^{-5} \mathrm{~cm} / \mathrm{s}$ & $10.28 \%$ & Not effective \\
\hline $7 \mathrm{ft}(2.134 \mathrm{~m})$ & High $2 \times 10^{-5} \mathrm{~cm} / \mathrm{s}$ & $11.59 \%$ & Not effective \\
\hline $10 \mathrm{ft}(3.048 \mathrm{~m})$ & High $2 \times 10^{-5} \mathrm{~cm} / \mathrm{s}$ & $19.38 \%$ & Not effective \\
\hline
\end{tabular}

Table 4.9: Classification system for decision of hydraulic barrier effectiveness

\begin{tabular}{|l|l|}
\hline Flow above hydraulic barrier layer & Decision classification \\
\hline $75-100 \%$ & Effective \\
\hline $50-75 \%$ & Mostly effective \\
\hline $25-50 \%$ & Somewhat effective \\
\hline $0-25 \%$ & Not Effective \\
\hline
\end{tabular}


Figure 4.8 and Figure 4.9 show the model results for the 5-foot hydraulic barrier layer with the low and high hydraulic conductivity values, respectively. Flowpath 'streamlines' trace the path that water particles would take through the slope. A majority of the streamlines stay within the drainage and growth layers for the low hydraulic conductivity simulation (Figure 4.8) with only a small amount of downward seepage noted, mainly near the toe of the slope. When the hydraulic conductivity is increased, as in the case modeled for Figure 4.9, much more downward movement of the streamlines is noted, although a majority of this movement is still observed near the slope toe. A final observation is that a larger amount of water pooling (designated by blue coloration) is larger on the slope with the infiltration layer with a higher hydraulic conductivity. This indicates that water is entering the fill material and pore pressure is increasing.

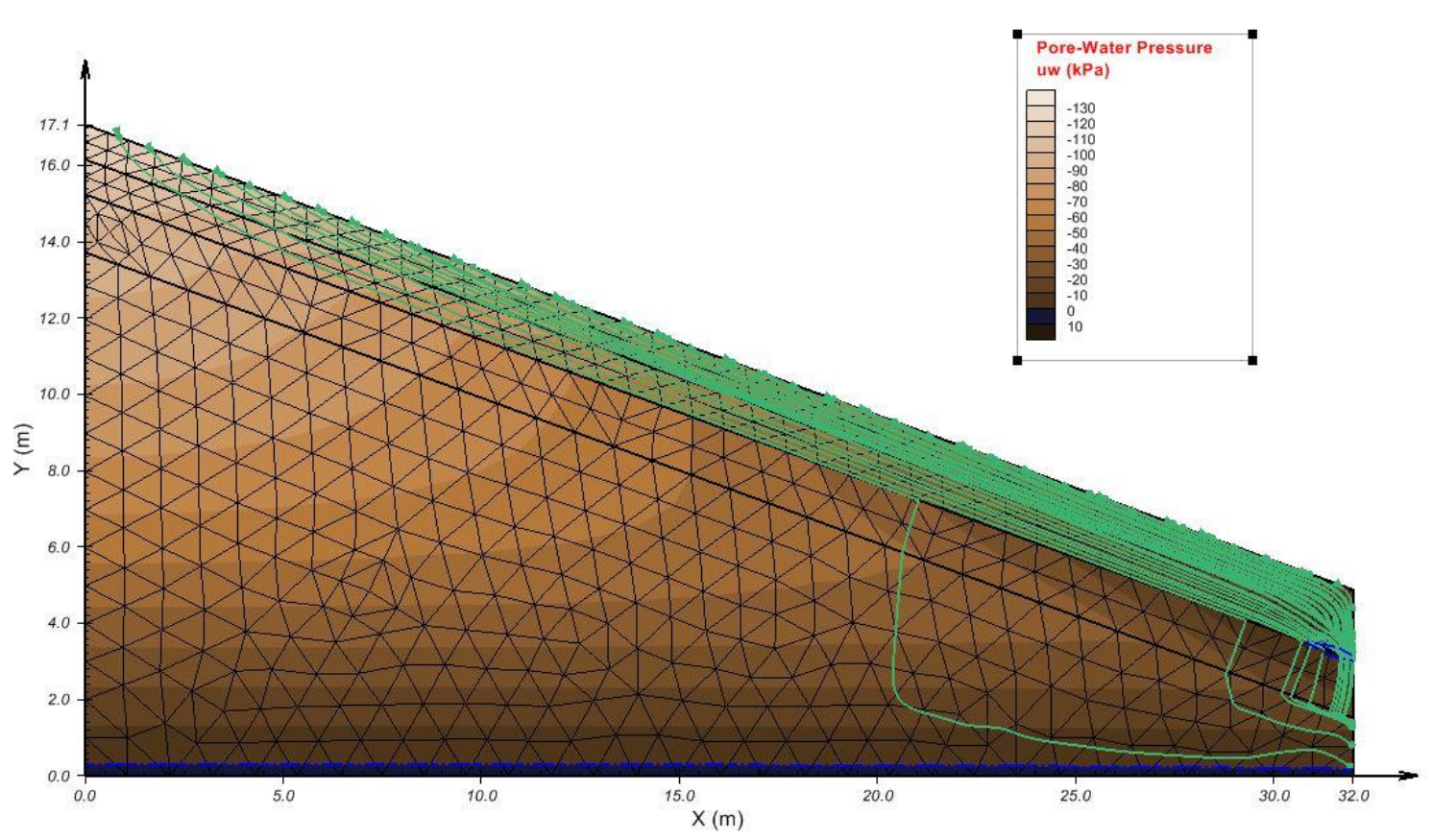

Figure 4.8: Seepage model for 5 foot hydraulic barrier layer and low hydraulic conductivity 


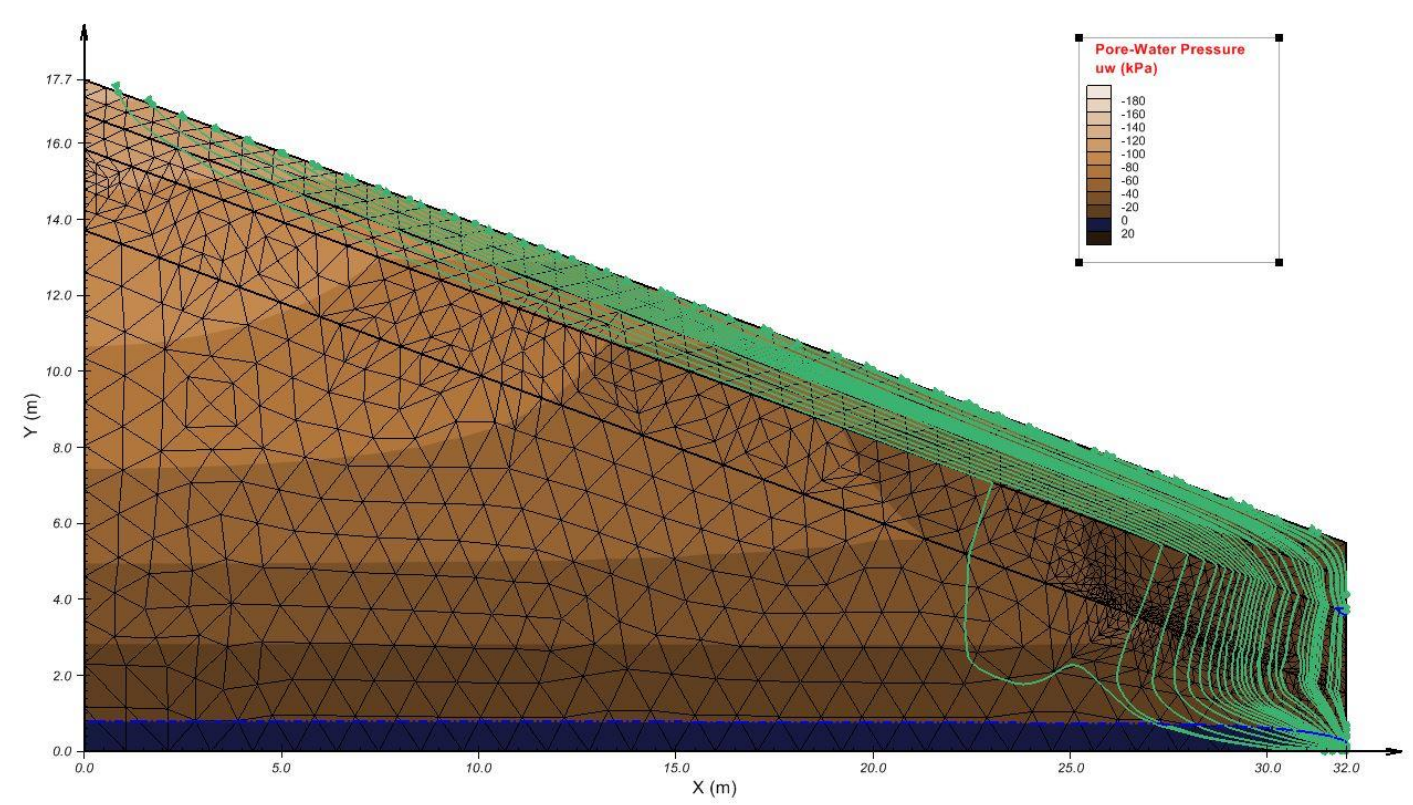

Figure 4.9: Seepage model for 5 foot hydraulic barrier layer and high hydraulic conductivity

Present in both Figure 4.8 and Figure 4.9 was a flowline located just past $x=20 \mathrm{~m}$. This line is located away from the other flowlines in the figures and there was question whether the line represented the actual physical behavior expected in the field condition, or if it was a product of the mathematics in the model. To evaluate this, the degree of saturation and fluxes were evaluated within the model. An examination of the point where the furthest upslope flowline begins in Figure 4.9 shows the degree of saturation equal to approximately $27 \%$ and a very small flux value $\left(\sim 10^{-4} \mathrm{~m} / \mathrm{d}\right)$. This indicates that the plotted line represents almost no flow. It is plotted as a mathematical output, but the low flow is representative of what would be expected in the field condition for a partially saturated material.

\section{5) Conclusions and discussion}

A multi-layer cap and cover system was designed for use in the reclamation of the Royal Scot coal refuse pile. A three-layer design was proposed, consisting of growth, drainage, and hydraulic barrier layers. The purpose of the design was to increase reduce total infiltration, remove water that had flowed into the landform prior to exposure to the bulk of the refuse fill, provide a medium for growth of vegetation, and maintain geotechnical stability. Using finiteelement computer modeling software, the design was evaluated for both slope stability and its performance in controlling seepage in the landform.

Slope stability modeling indicated the cover must be placed on slopes at a gradient of $2.5 \mathrm{H}$ to $1 \mathrm{~V}$ to be stable at strength parameters (reduced for uncertainty) derived from laboratory testing. This stability is extremely sensitive to cohesion, which was significantly reduced from laboratory obtained values to account for uncertainty. 
Seepage modeling was over a 2-year time period completed on a $2.5 \mathrm{H}$ to $1 \mathrm{~V}$ slope to determine the recommended design parameters for the hydraulic barrier layer. A constant total infiltration of $55 \%$ of the average precipitation at the site was applied to the slope. The cover designs incorporating hydraulic barrier layers of 3 or 5 feet and a hydraulic conductivity of less than $2 \mathrm{x}$ $10^{-6} \mathrm{~cm} / \mathrm{s}$ were determined to be effective in reducing infiltration reaching the underlying coarse coal refuse by a minimum of $85 \%$. These findings show that if correctly designed and constructed, the cap and cover system has significant potential to reduce groundwater flow entering the coarse coal refuse fill and thereby reducing acid-mine drainage generation.

Based on the cover modeling results, the following recommendations were made for the designs of slopes to be used in the geomorphic reclamation design:

- The maximum slope should be set to $2.5 \mathrm{H}$ to $1 \mathrm{~V}$ (21.8 degrees).

- The hydraulic conductivity of the hydraulic barrier layer should be no more than $10^{-6}$ $\mathrm{cm} / \mathrm{s}$ and obtaining a low hydraulic conductivity is essential to the overall performance of the cap and cover system

- Compaction energy greater than or equal to standard proctor effort should be applied to the barrier layer to achieve the low hydraulic conductivity. The creation of fines through the compaction is essential to creating a low-permeability material. The achieved dry density should be approximately $16 \mathrm{kN} / \mathrm{m}^{3}$

- The minimum thickness of the hydraulic barrier layer should be 3 feet $(0.915 \mathrm{~m})$ 


\section{5) DESIGN AND MODELING OF GEOMORPHIC SLOPES}

After evaluating and designing the parameters for the multi-layer cap and cover system, the cover was applied to several reclamation design alternatives for the Royal Scot site. Three designs were evaluated: a conventional 'bench slope' design and two designs incorporating geomorphic landform reclamation (GLD). Analysis was completed on selected slopes from the designs to evaluate the slope stability and performance of the applied cap and cover system. Following the analysis, the designs were compared for applicability and design recommendations are presented.

Four main design criteria were evaluated for each slope:

- Stability: Factor of safety of greater than or equal to 1.5 as required by West Virginia DEP

- Seepage control: Large percentage of infiltrated rainfall being drained above the hydraulic barrier layer

- Geomorphic criteria: creation of geomorphic slopes and stream channels

- Earthmoving requirements: approximate cut and fill volume from the initial site grading to the final proposed design grade

Slopes of several grades were considered in this chapter. Table 5.1 provides a summary of the slopes and the measurement units for each used.

Table 5.1: Summary of slope measurement descriptions

\begin{tabular}{|l|l|l|}
\hline Slope grade $(\%)$ & Slope $(\mathrm{H}: \mathrm{V})$ & Slope (degrees) \\
\hline 50 & $2: 1$ & 26.6 \\
\hline 40 & $2.5: 1$ & 21.8 \\
\hline 33 & $3: 1$ & 18.4 \\
\hline
\end{tabular}

\section{1) Evaluation of existing landmass}

The first slope to be evaluated was from the existing landmass. The purpose of this model was to compare the stability of the existing landform shape to those of the reclamation alternatives. The current landmass has remained unchanged for approximately the last 14 years, and shows major erosive features including deep gullying signifying large amount of sediment transport. Using the slope zone analysis tool within Carlson Mining, the critical slope, which contained the steepest areas and had a long length, was identified in the southern section of the fill. As a result of these attributes, it would be expected that if this site were to be geotechnically stable, the remainder of the site would be as well.

The results of the slope analysis are shown in Figure 5.1 with the highest slopes identified with orange and red coloration and the lowest slopes with blue. The critical slope is identified on this figure as well. 


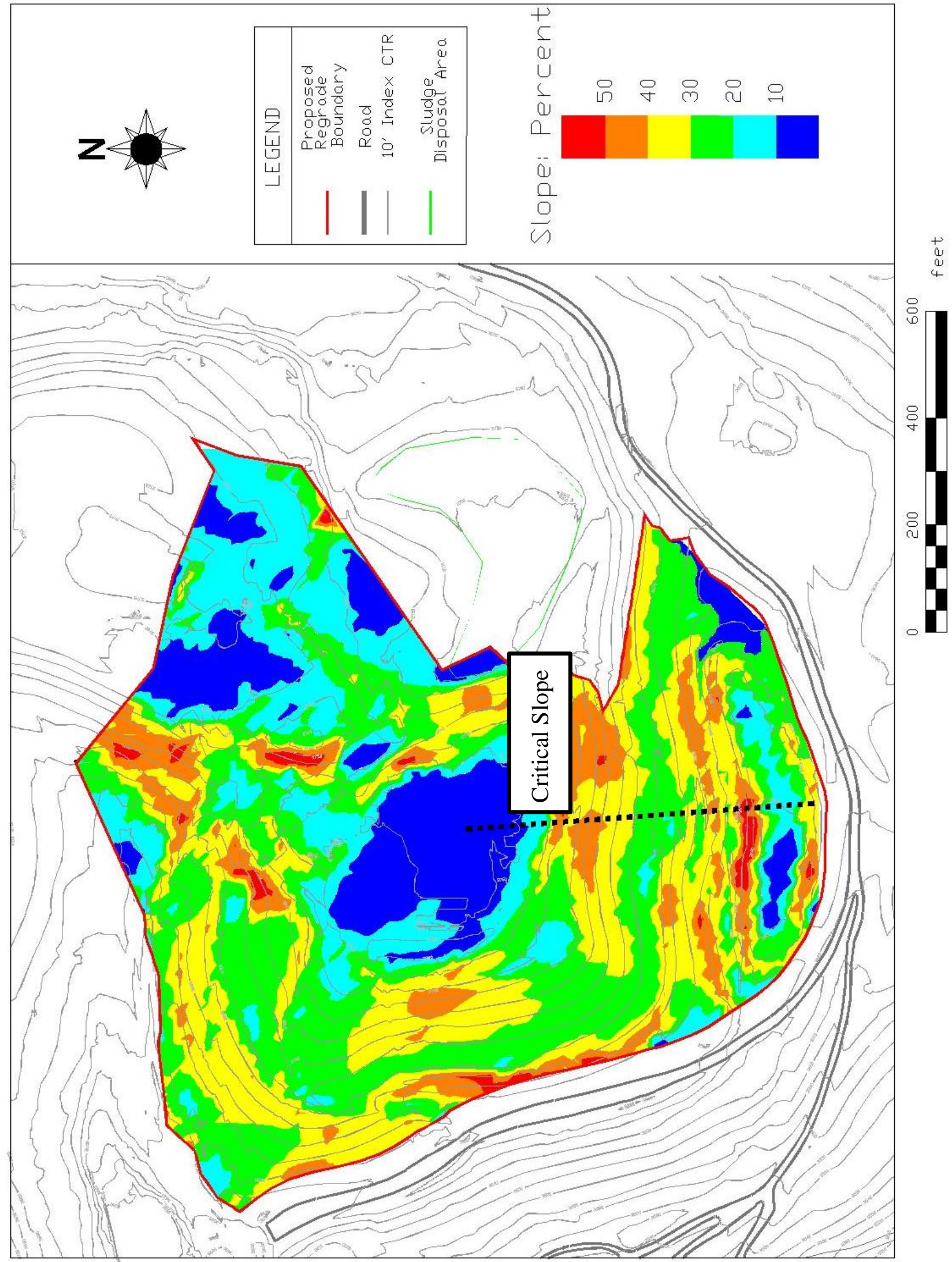


Figure 5.1: Slope analysis and critical slope location of existing fill

The cross-section of the selected slope and potential failure planes with a factor of safety below 2.0 are given in Figure 5.2. As no major reclamation or compactive efforts have been applied to the site, the entire cross-section was assumed to be composed entirely of the loose CCR shale material. The minimum factor of safety was determined to be 2.368 based on 1000 potential failure surfaces created by SVSlope ${ }^{\mathrm{TM}}$ and analyzed with the General Limit Equilibrium (GLE) analysis method.

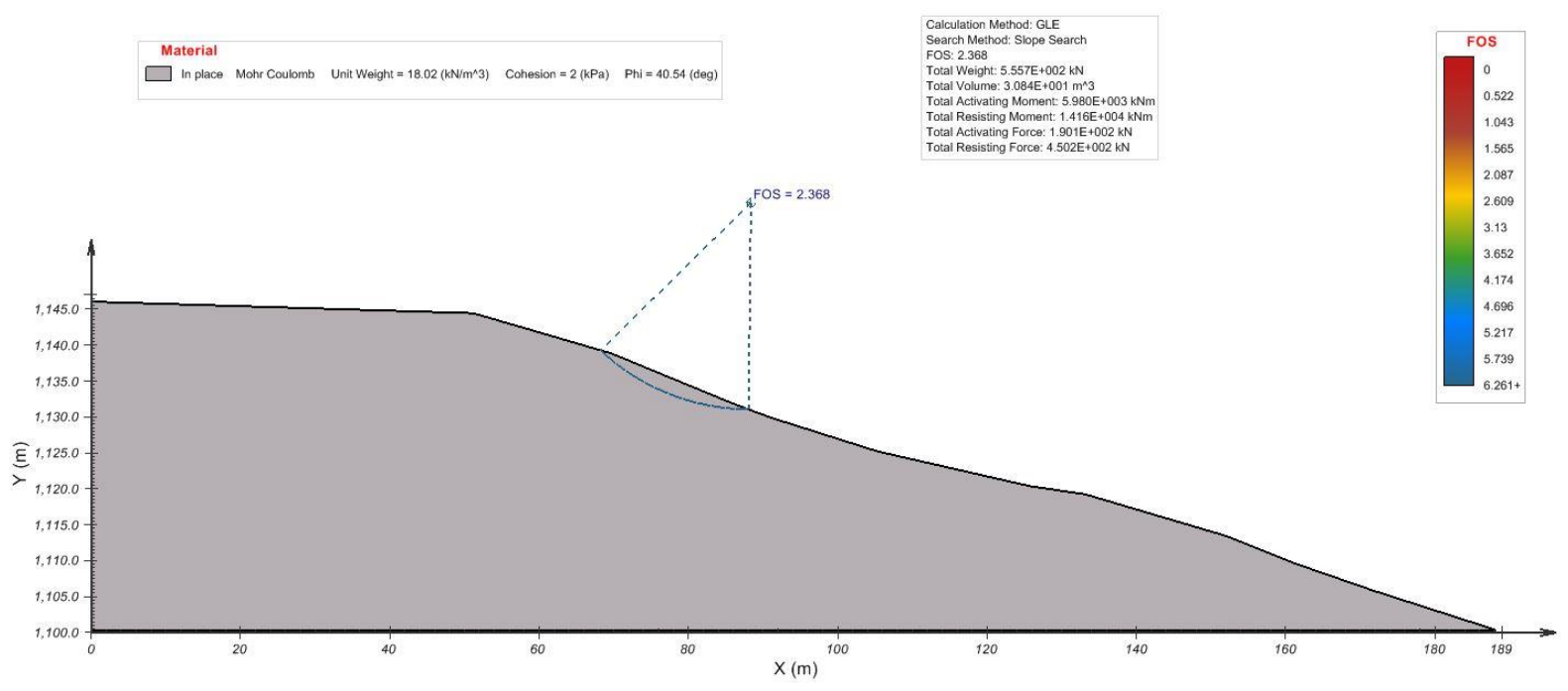

Figure 5.2: Slope stability analysis of existing fill

\section{2) Design Iteration 1 (Conventional bench-slope design)}

For the first reclamation alternative, the Royal Scot refuse site was regarded into a conventional benched design. This design incorporated four planar slope faces, benches, and uniform slope angles as illustrated in Figure 5.3 and Figure 5.4. Design characteristics included: $15.24 \mathrm{~m}$ (50 ft) elevation change between benches, $6.10 \mathrm{~m}(20 \mathrm{ft})$ bench widths, and $2.5 \mathrm{H}: 1 \mathrm{~V}$ slopes $\left(21.8^{\circ}\right)$. 


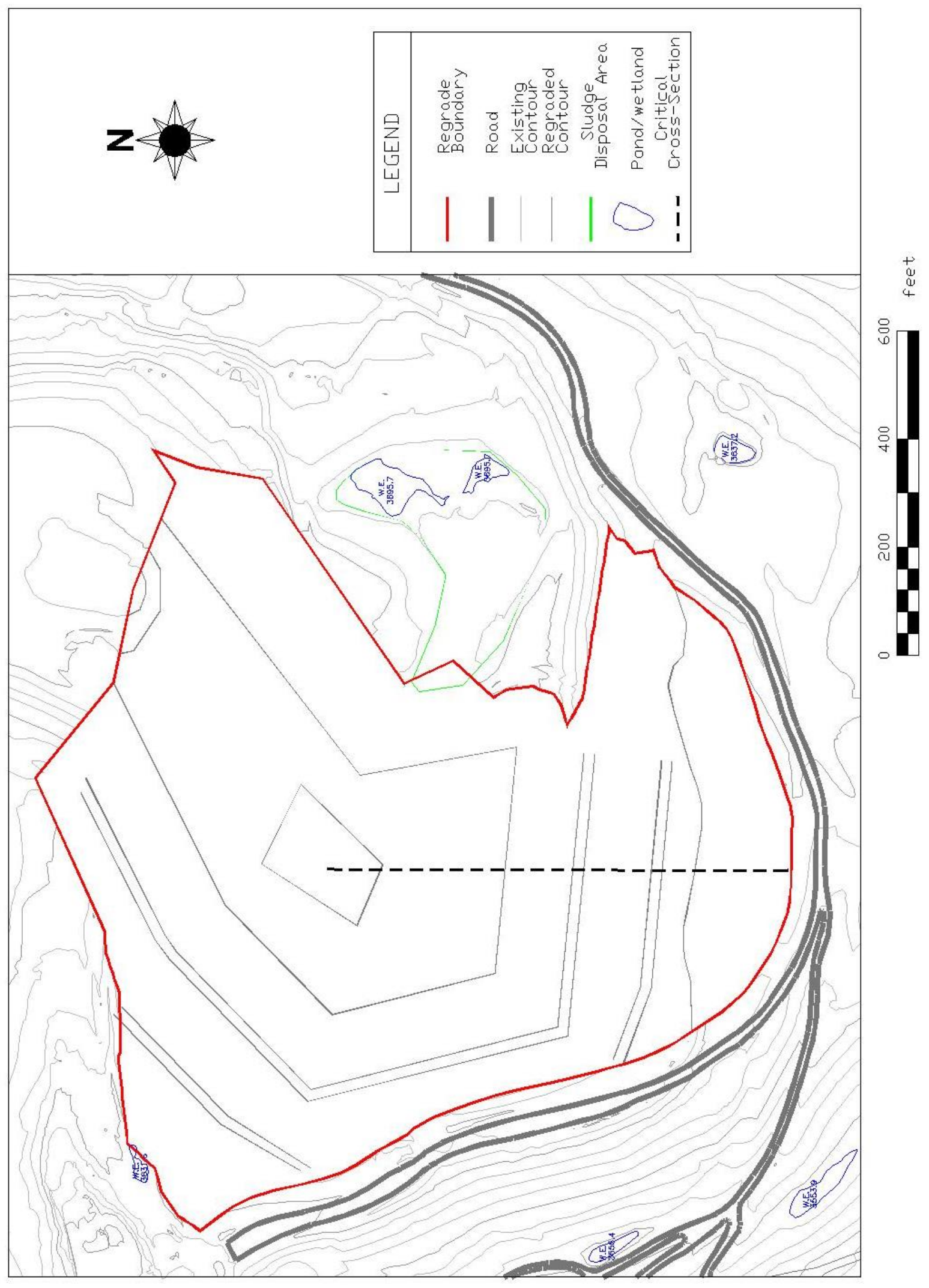

Figure 5.3: Plan view and critical slope of conventional design 


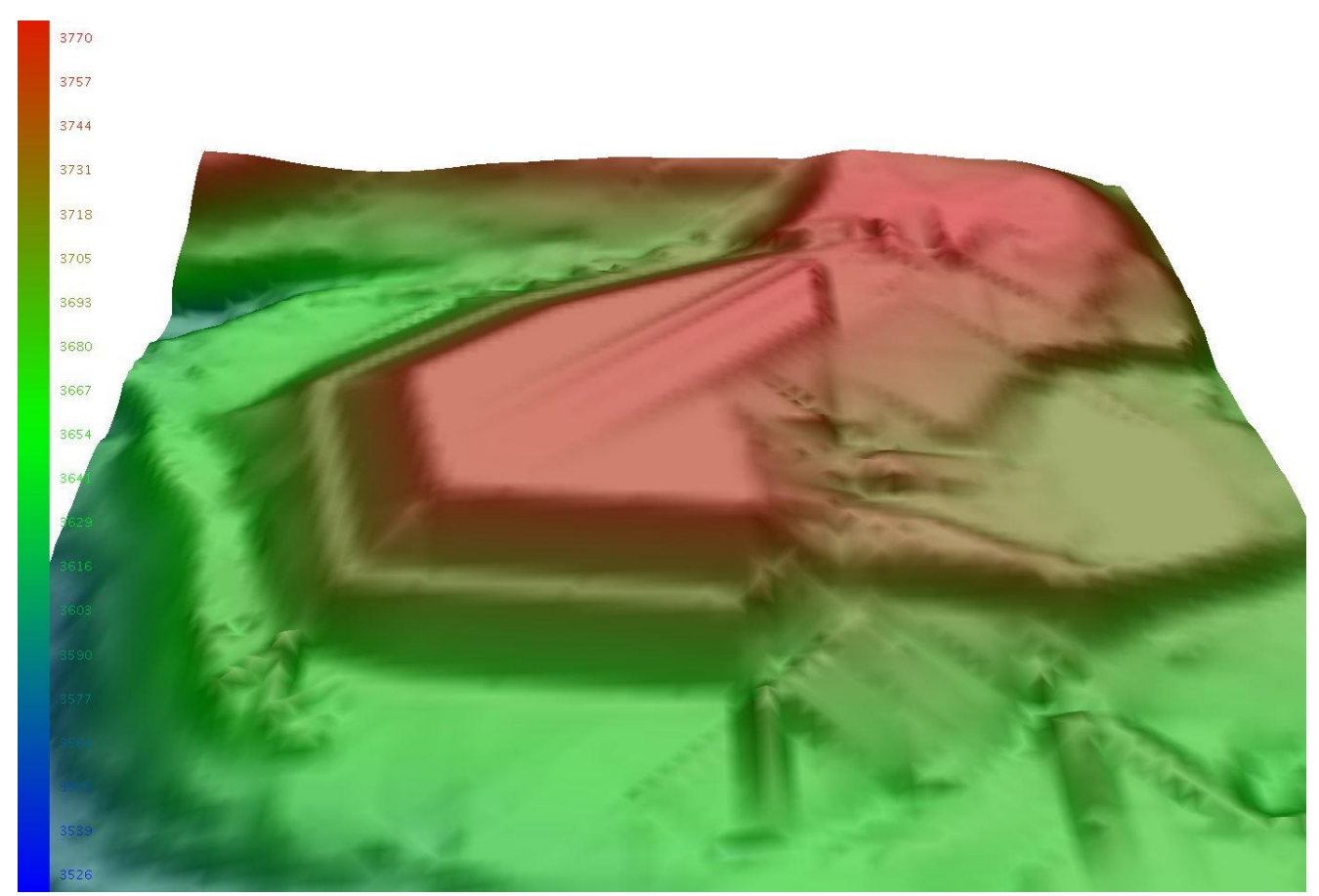

Figure 5.4: $3 D$ view of the conventional design

Using the cut/fill volumes feature in Carlson Mining (Maysville, Kentucky), the existing surface was compared to the proposed benched reclamation to calculate an approximate volume of material that would need to be relocated. This volume was calculated to be 195,000 cubic yards $(149,000$ cubic meters). The cut/fill volume is an important consideration in the comparison of reclamation alternatives as it offers a basis for cost estimation.

The south slope (red line in Figure 5.3) was selected as a representative cross-section for modeling purposes. This slope consists of the same common slope profile as designed into the entire property as well as a long slope length. The cap design proposed in Chapter 4 was then applied to the slope for analysis of slope stability and seepage performance.

\subsection{1) Stability Modeling}

Slope stability analysis was completed for the conventional design with the cap and cover system applied. The geometry was created inside of SVSlope ${ }^{\mathrm{TM}}$ and 1000 potential failure planes were automatically generated. The GLE analysis method was used to calculate a factor of safety value for each of these planes. A minimum factor of safety of 1.714 was indicated for the slope which exceeds the required value of 1.5 . Figure 5.5 illustrates the stability modeling results. 


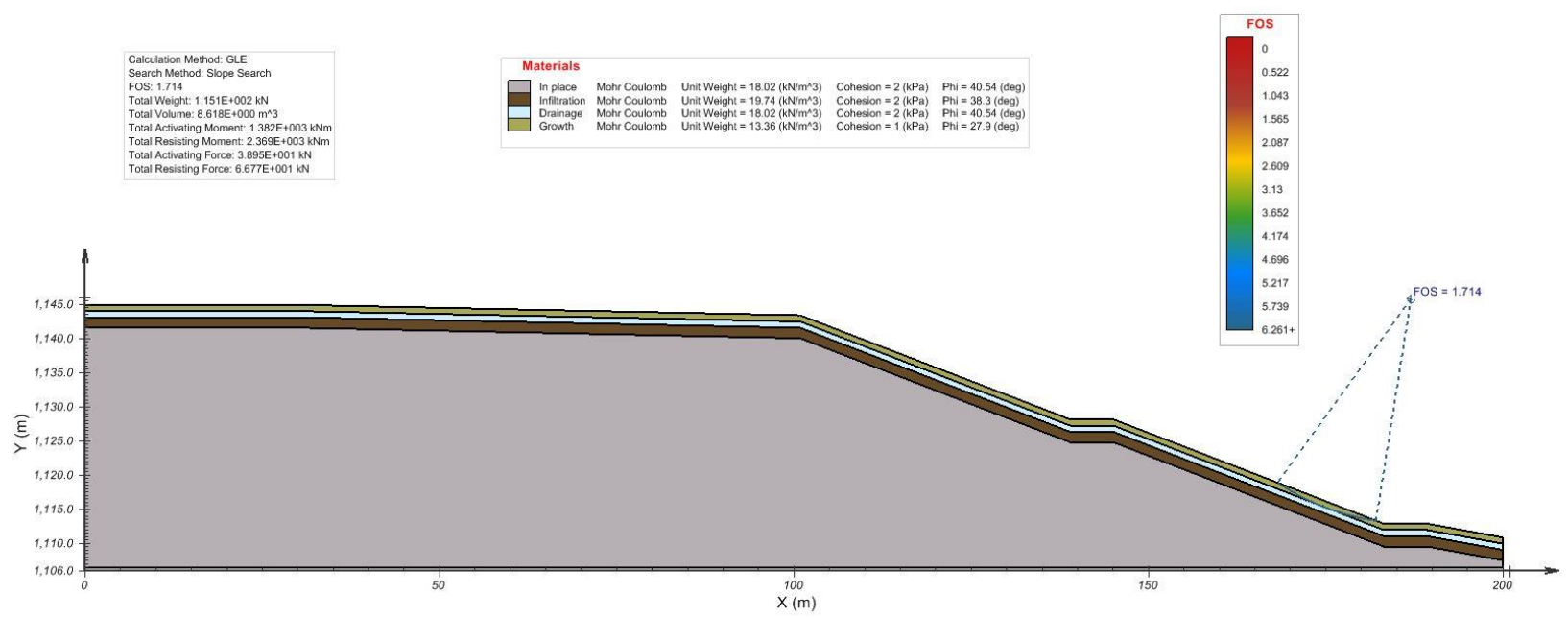

Figure 5.5: Stability Modeling results for conventional design

\subsection{2) Seepage Analysis}

Groundwater seepage analysis was completed on the conventional slope to analyze the performance of the cap and cover system on the full slope. As with the seepage performance modeling conducted in section 4.4, a constant infiltration rate of $0.00204 \mathrm{~m} / \mathrm{d}(55 \%$ of the daily precipitation) was applied to the slope over a two-year time period. Flux lines were placed at the toe of the slope to measure the flow through each layer and the water flow above the hydraulic barrier was compared to flow below the layer. Results from the seepage modeling showing pore pressures are shown in Figure 5.6. The stream traces of particles moving through the slope are shown in Figure 5.7. Table 5.2 gives a summary of the flow through each layer of the cover.

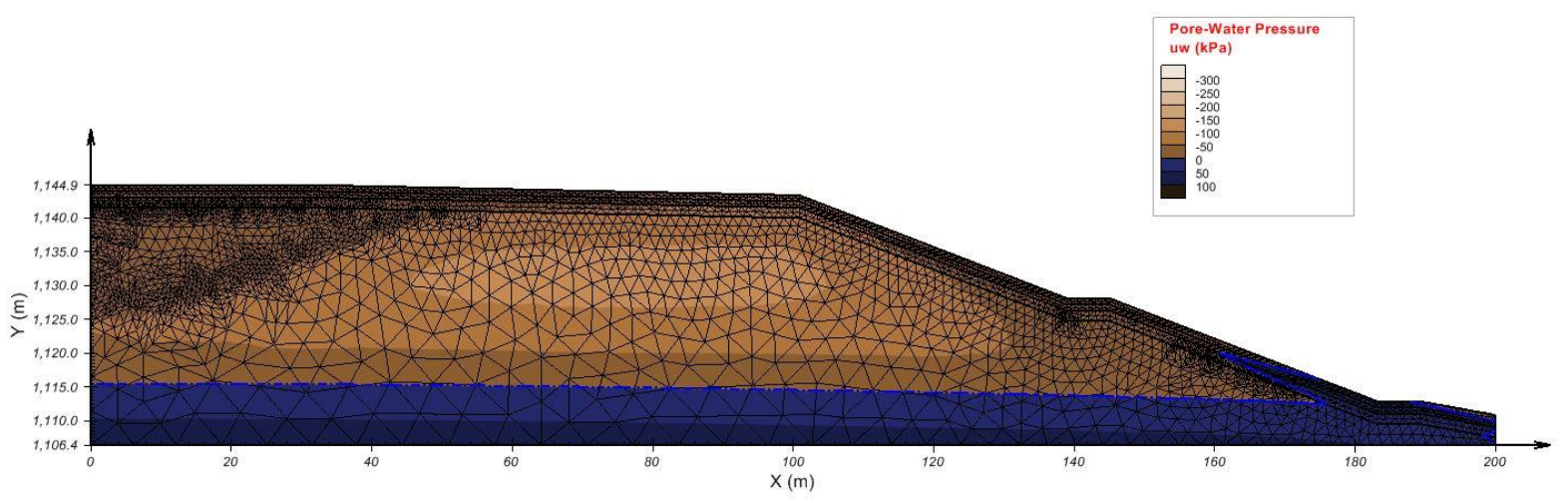

Figure 5.6: Seepage modeling results for conventional design 


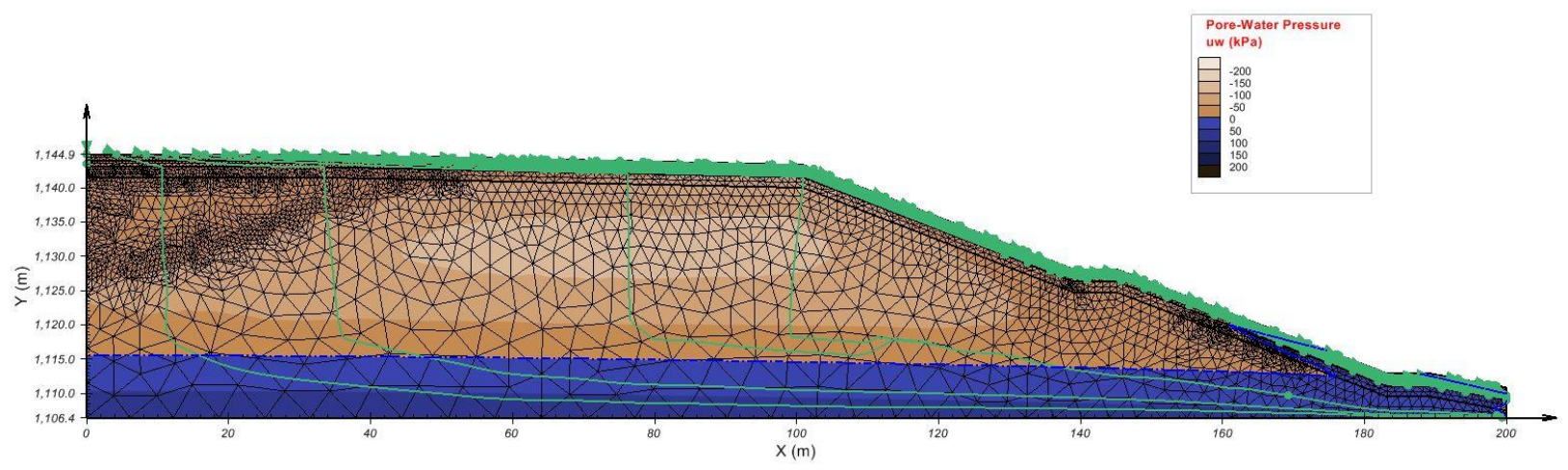

Figure 5.7: Seepage modeling results and water streamtrace paths for conventional design after two years

Table 5.2: Seepage model result summary for iteration 1 conventional design

\begin{tabular}{|c|c|}
\hline Layer & $\begin{array}{c}\text { Percentage of total } \\
\text { outflow }\end{array}$ \\
\hline Growth Layer & 10.49 \\
\hline Drainage Layer & 61.41 \\
\hline Hydraulic Barrier & 0.12 \\
\hline Fill material & 27.98 \\
\hline TOTAL FLOW ABOVE & 71.90 \\
\hline BARRIER & \\
\hline
\end{tabular}

Model results indicated that approximately $72 \%$ of water flowing through the slope would pass above the hydraulic barrier and remain as saturated flow within the loose shale drainage layer and the MGro ${ }^{\mathrm{TM}} /$ shale growth layer. The streamtrace plot in Figure 5.7 indicates that a majority of the infiltration in the barrier would occur in the flat surfaces located near the slope's crest.

An additional issue observed in the models is a buildup of pore pressure in the slope. The blue coloration located Figure 5.6 shows that the cap and cover are completely saturated from the toe until about halfway up to the second bench. The pore pressure build-up is concerning, as it can reduce soil strength and lead to increased slope stability.

\section{3) Design Iteration 2 (Geomorphic Design \#1)}

The second design iteration for the reclamation of the Royal Scot site incorporated the principles of geomorphic landform design (GLD). Carlson Natural Regrade with GeoFluv ${ }^{\mathrm{TM}}$ was used to create a surface with geomorphically stable ridges and stream channels within the fill material. The benched conventional design surface was used as the initial surface for this design such that areas where geomorphic design were not applied. A total of four stream channels were created as shown by the blue lines on Figure 5.8 and in the 3-D rendering (Figure 5.9) to quickly and efficiently remove runoff water from the site. Comparing the surface of this design to the existing pile profile estimates the earthmoving for this design to be approximately 325,000 cubic yards $(248,480$ cubic meters). 


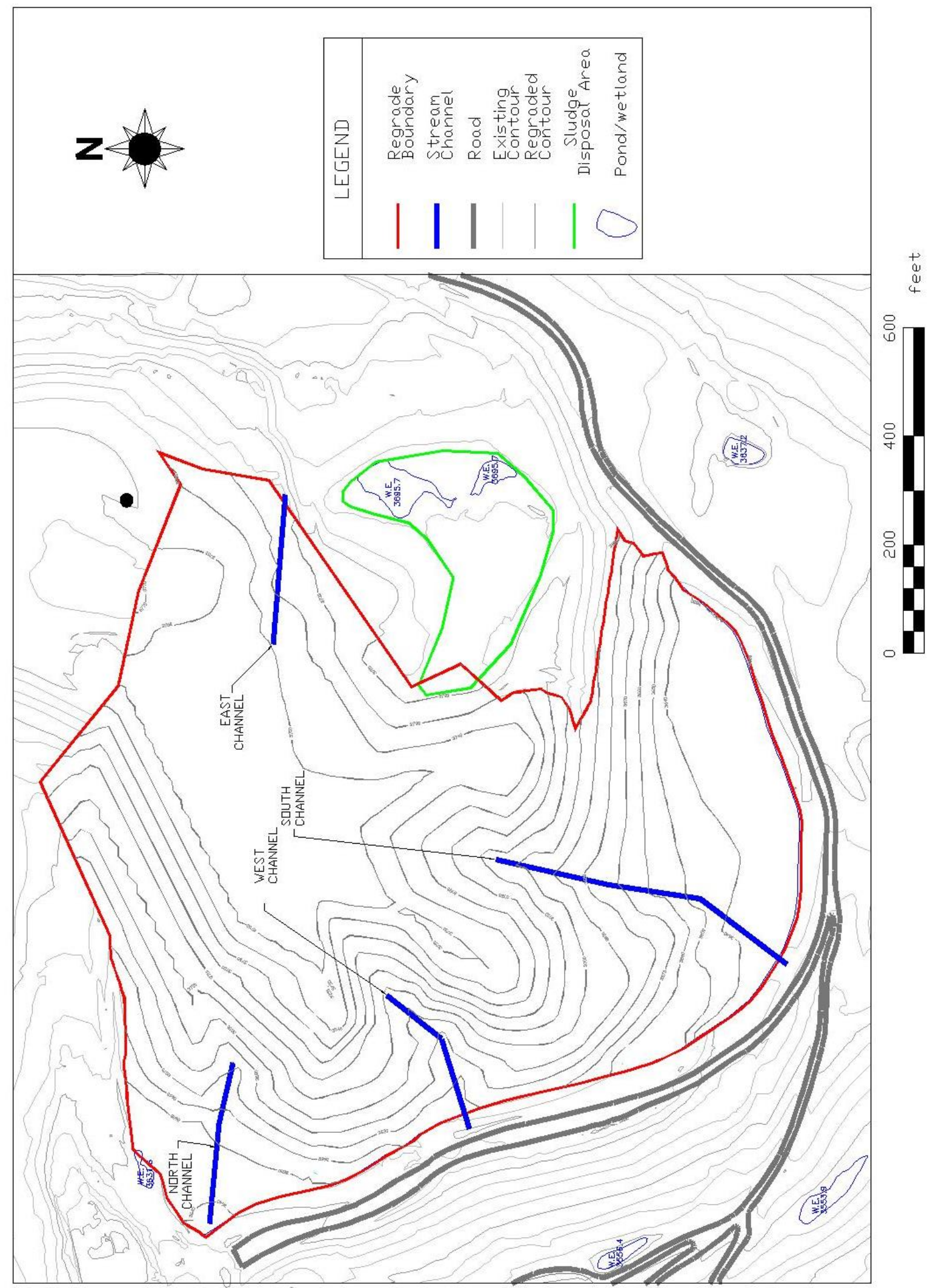

Figure 5.8: Plan view of Iteration \#2-first geomorphic design 

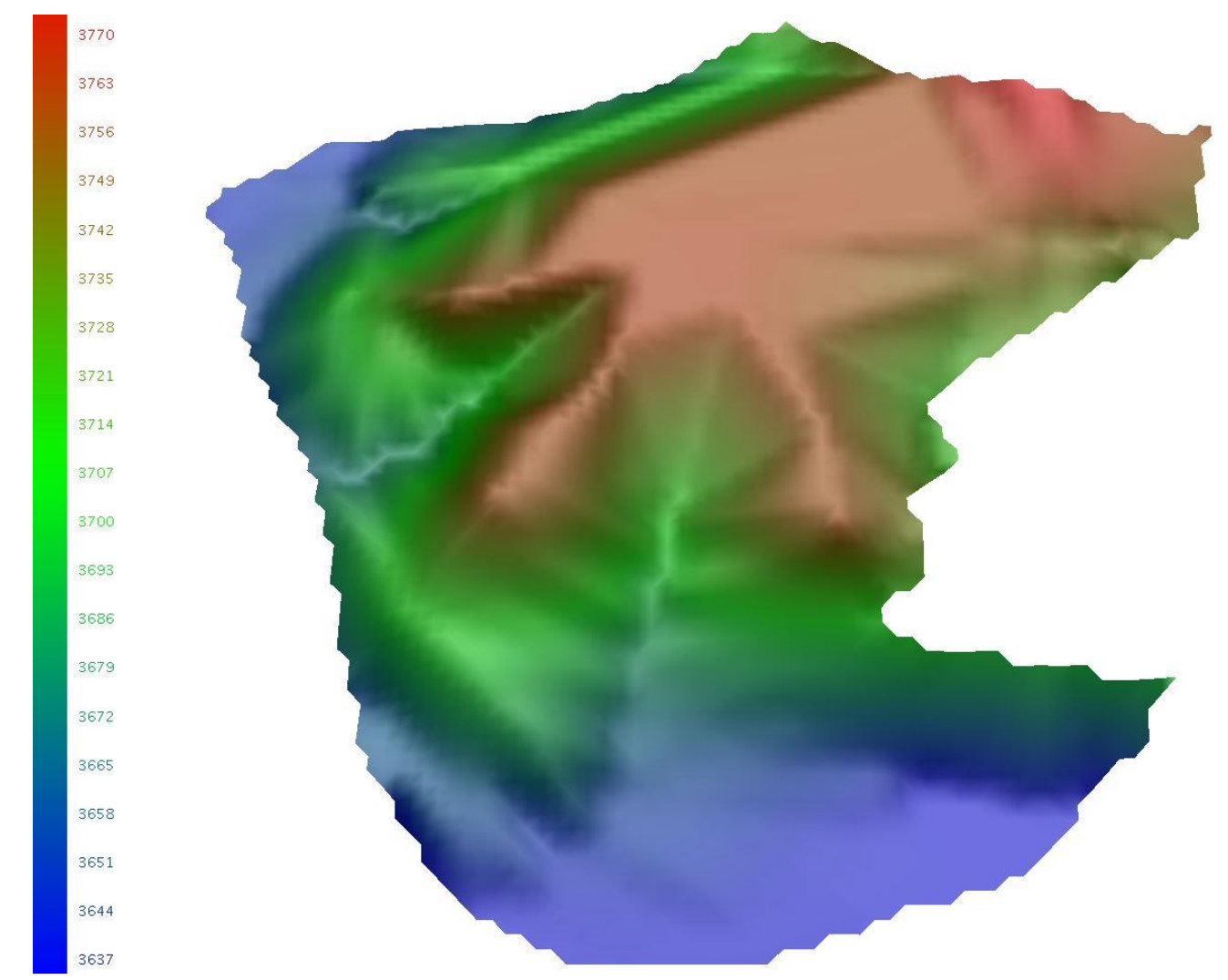

Figure 5.9: $3 D$ rendering of Iteration \#2- first geomorphic design

The critical slope selected for modeling was one of the steepest found in the design, located on the western side of the site as shown in Figure 5.10. The slope indicated on this portion of the slope is in excess of $50 \%$ grade ( $>2: 1$ slope). This slope is steeper than recommended for the application of the cap and cover system as modeled in Chapter 4. Slope stability and seepage analysis were completed for the critical slope to evaluate its geotechnical stability and the performance of the multilayer cap and cover system. 


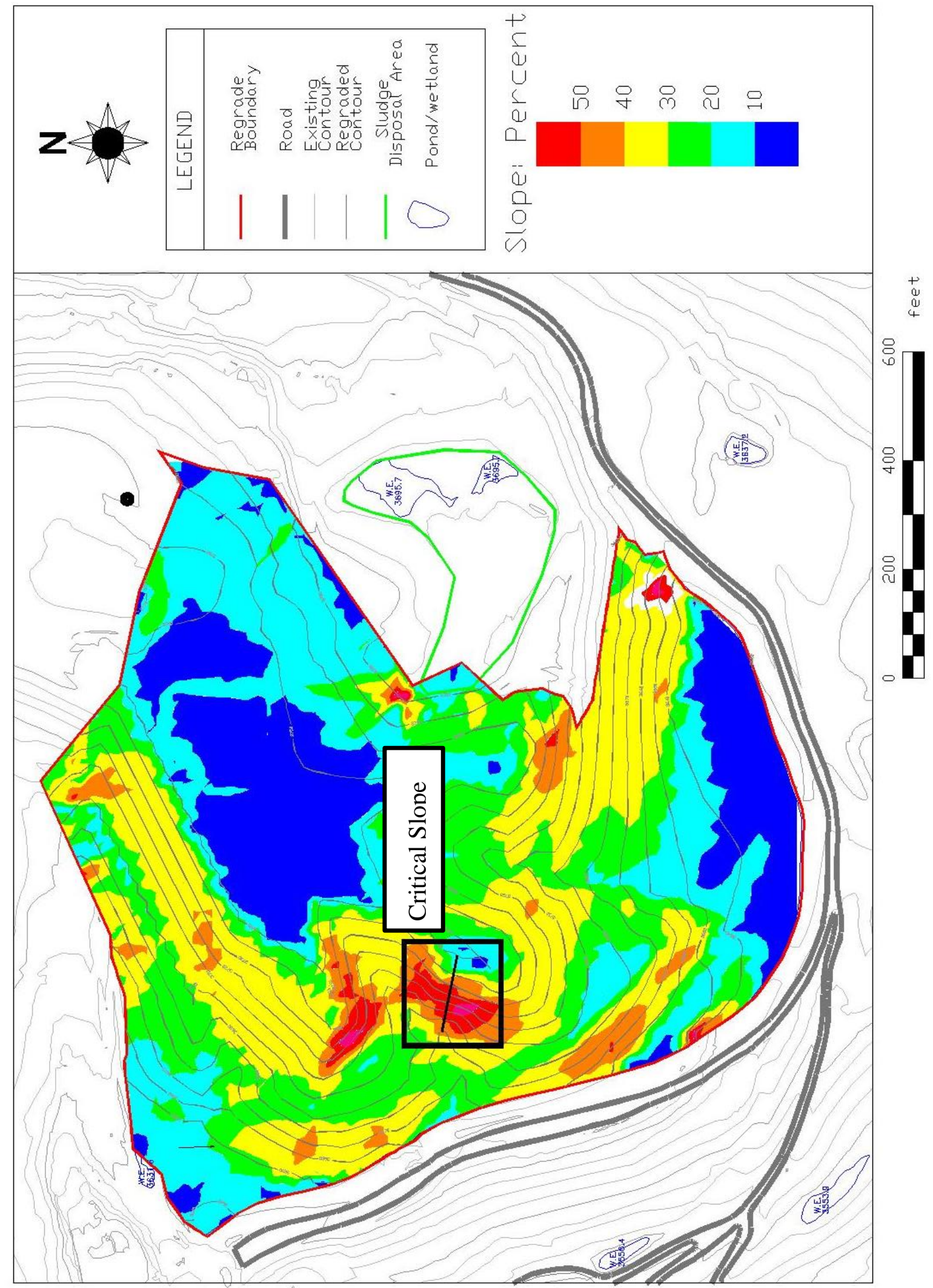

Figure 5.10: Slope zone analysis and location of critical slope on second design iteration 


\subsection{1) Stability Modeling}

Stability modeling was completed in SVSlope ${ }^{\mathrm{TM}}$ for the selected critical slope at the soil properties determined in Section 4.2 with the cap and cover system designed in Chapter 4. The hydraulic barrier layer was compacted to follow a benched surface. The drainage layer was placed over the benches to form the final surface profile upon which the growth layer was applied rather than being designed to follow the surface topography. Varying bench slope angles were used within the slope as shown in Figure 5.11. The purpose of adding the benching was to determine if this method added stability benefits as well as to provide areas for the potential addition of internal drains.

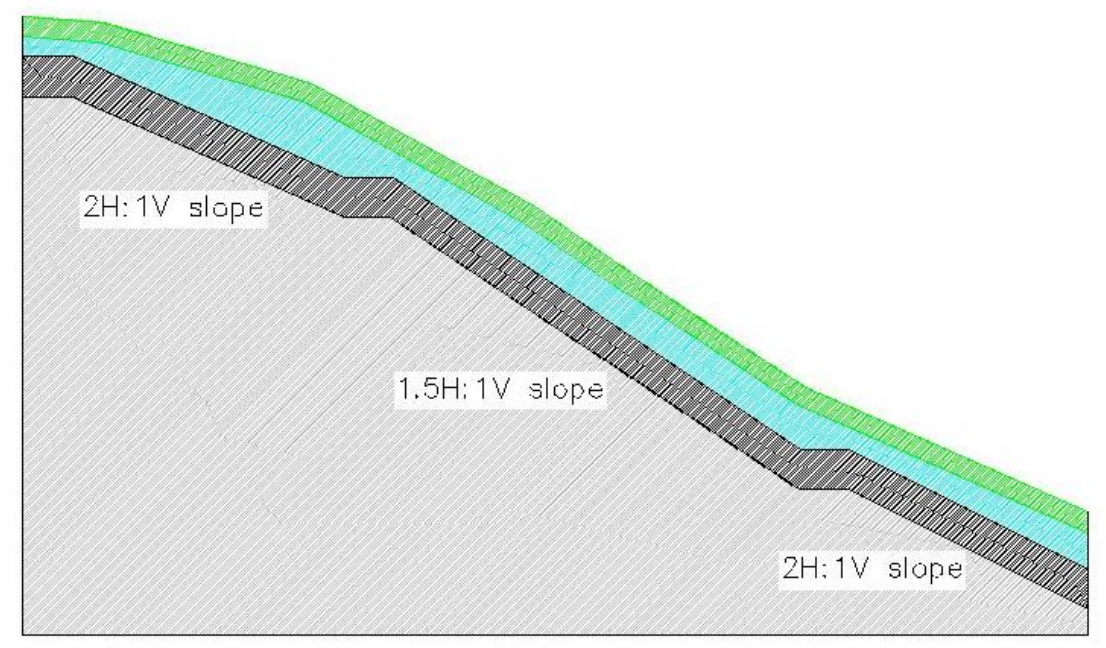

Figure 5.11: Geometric profile of slope cross-section for Iteration \#2

One thousand potential failure planes were created on the slope and a factor of safety was calculated for each using the GLE analysis method. A minimum factor of safety of 1.212 was calculated for the slope. This value is below the minimum required factor of safety of 1.5 . The critical failure surface, along with all others with a factor of safety less than 1.5 are shown in Figure 5.12. The slope did not meet the required factor of safety value due to the steep slopes used in its construction. The middle benched surface was graded to $1.5 \mathrm{H}: 1 \mathrm{~V}$ (67\% grade or 33.7 degrees) which is significantly steeper than the $2.5 \mathrm{H}: 1 \mathrm{~V}$ slope recommended in Section 4.5. 


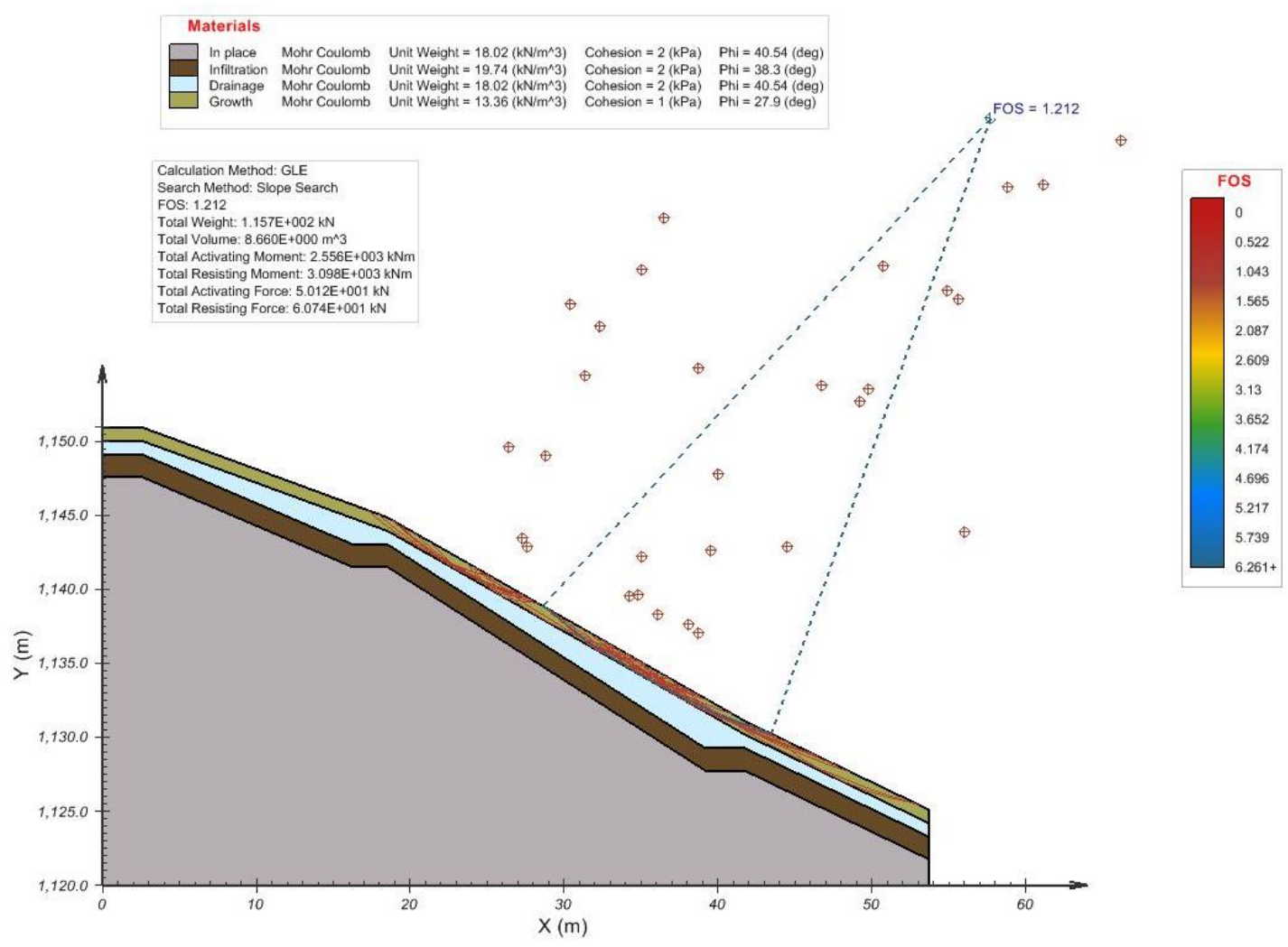

Figure 5.12: Slope stability analysis for iteration \#2 and failure surfaces with FOS $<1.5$

\subsection{2) Seepage Analysis}

Even though the slope stability analysis for this slope indicated that it did not meet the required minimum, seepage analysis using SVFlux ${ }^{\mathrm{TM}}$ was still completed. The purpose of the seepage analysis was to evaluate the performance of the cap and cover system and observe the differences on the geomorphic slope compared to the conventional design. The slope was subjected to a constant infiltration rate of $0.00204 \mathrm{~m} / \mathrm{d}$ ( $55 \%$ of total average daily precipitation) for a period of two years, as was done in section 5.2.2. Flux lines were placed at the toe of the slope to measure the cumulative flow through each layer. The amount of flow above the hydraulic barrier was then compared to that flowing out of the fill to estimate the efficiency of the cap and cover system on the slope. 


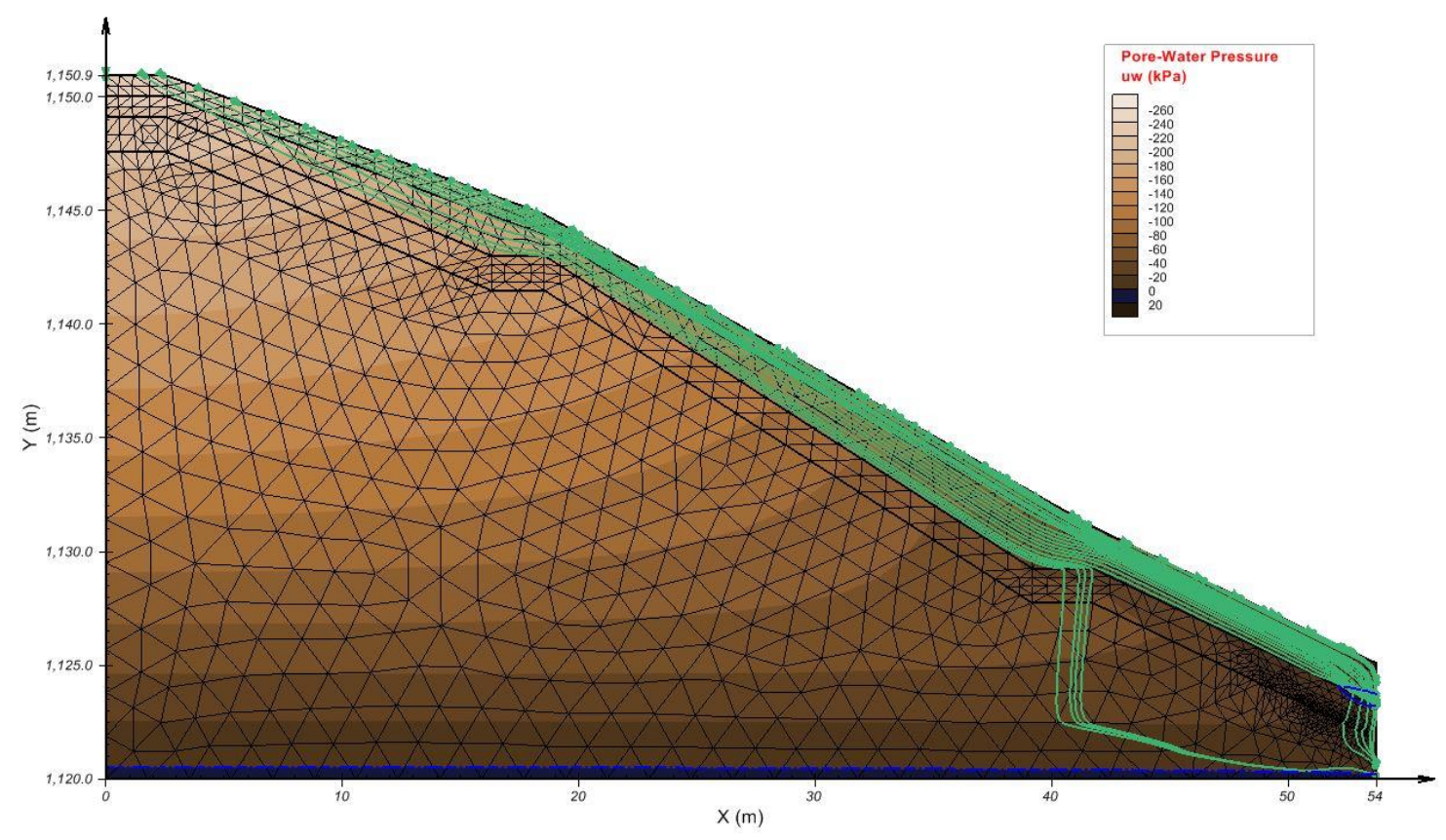

Figure 5.13: Seepage modeling results for iteration 2 slope with water flow path streamlines

Table 5.3: Seepage model result summary for iteration 2 critical slope

\begin{tabular}{|c|c|}
\hline Layer & Percentage of total outflow \\
\hline Growth Layer & 11.04 \\
\hline Drainage Layer & 81.88 \\
\hline Hydraulic Barrier & 0.05 \\
\hline Fill material & 7.03 \\
\hline $\begin{array}{c}\text { TOTAL FLOW ABOVE } \\
\text { BARRIER }\end{array}$ & 92.92 \\
\hline
\end{tabular}

This slope was estimated to capture $92.5 \%$ of infiltration and keep it above the hydraulic barrier layer. The flow paths shown in Figure 5.13 also show much of the flow being directed in the drainage and surface growth layers. A small amount of downward seepage is observed on the bench closest to the bottom of the slope. Additionally, no significant water buildup in the bottom of the slope is observed in this model, unlike the conventional cross-section modeled in section 5.2 .

\section{4) Design Iteration 3 (Geomorphic Design \#2)}

The third reclamation design alternative for the Royal Scot site used the lessons learned from the previous iterations to create an optimal design. Geomorphic reclamation principles were applied to create three stream channels on the site. Slopes on the site were designed to be less than or equal to $2.5 \mathrm{H}: 1 \mathrm{~V}$. A plan view map of design iteration is shown in Figure 5.14 and a 3D rendering is given in Figure 5.15.

Pl 


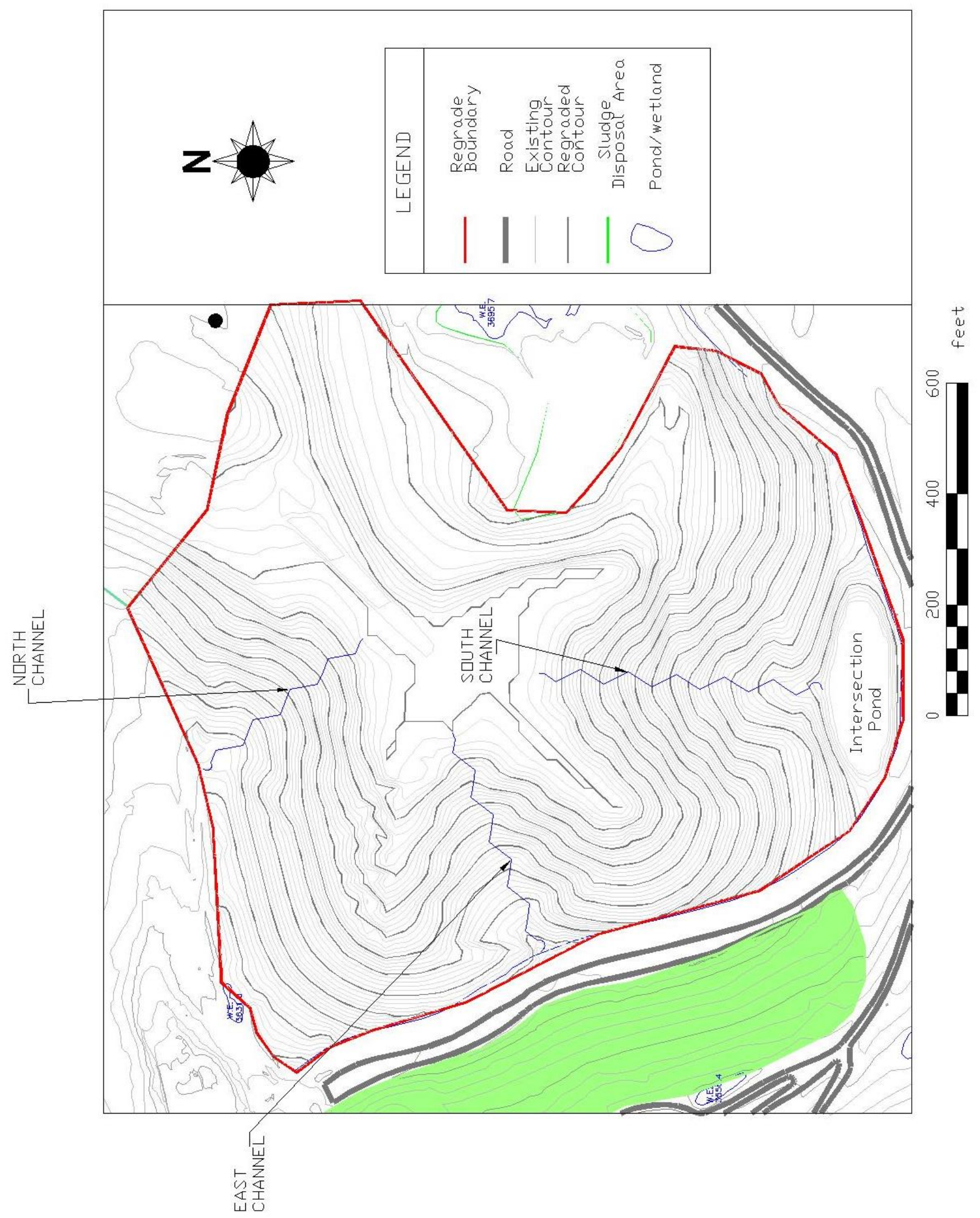

Figure 5.14: 2D plan map of design iteration 3 


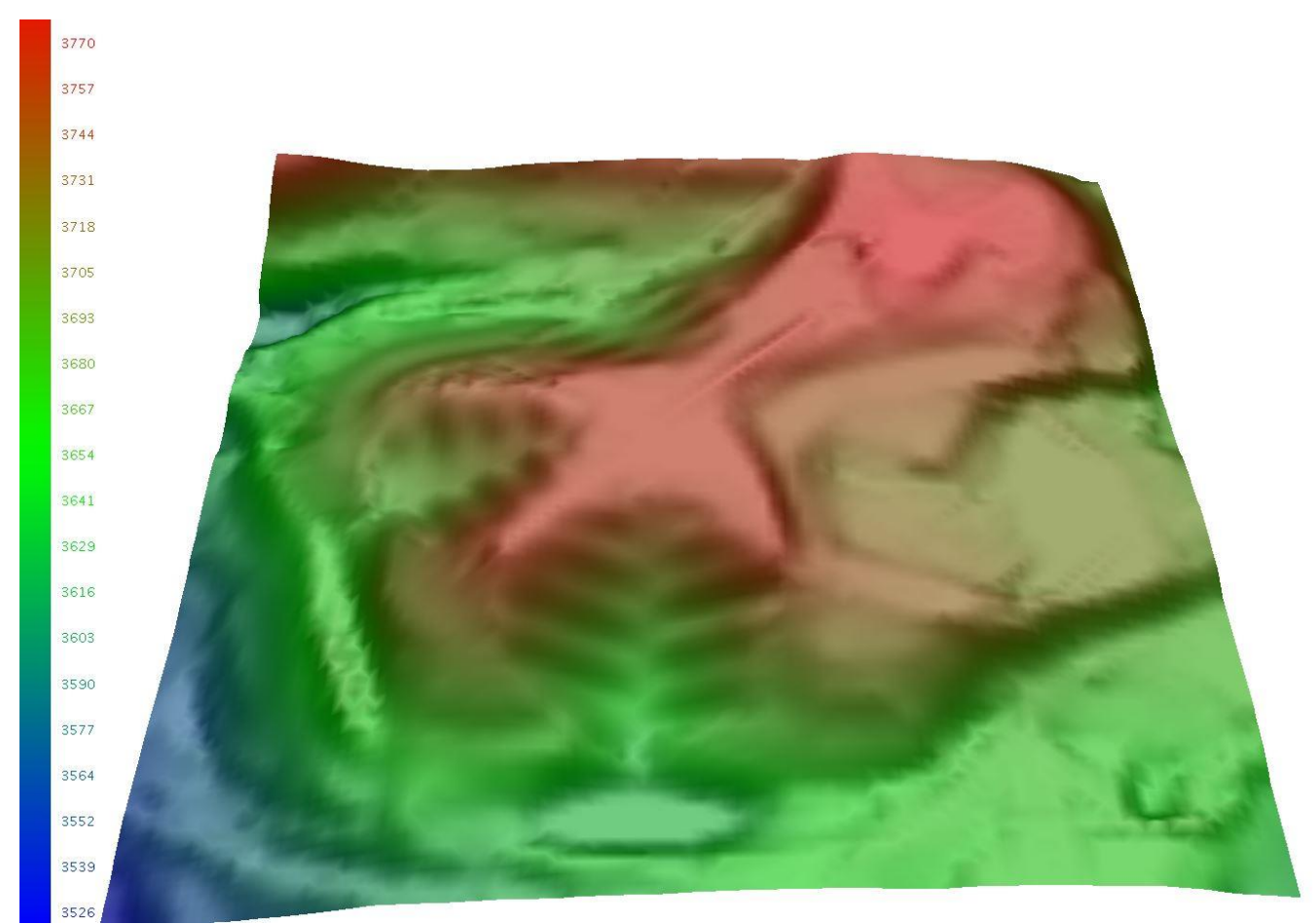

Figure 5.15: $3 D$ rendering of design iteration 3

Comparing the surface of design iteration 3 to the existing pile gives an estimated earthmoving cut/fill volume of 250,000 cubic yards (191,000 cubic meters). As with the previous designs, the earthmoving volume was balanced so that the cut volume equaled the fill volume and no material was gained or lost in the calculations.

Figure 5.16 shows the slope zone analysis for design Iteration 3. Only a small amount of areas on the design have a slope over $40 \%$ grade and areas that fall over 50\% grade are confined primarily to the edges of the site where they are the result of grid convergence issues. The critical slope on the site was selected as one of the steepest, with a portion falling between 40 and $50 \%$ grades. This slope was located on the western side of the property and is highlighted in Figure 5.16. An additional, shallower slope from the eastern side of the property was selected as the critical slope for seepage analysis (section 5.4.2). 


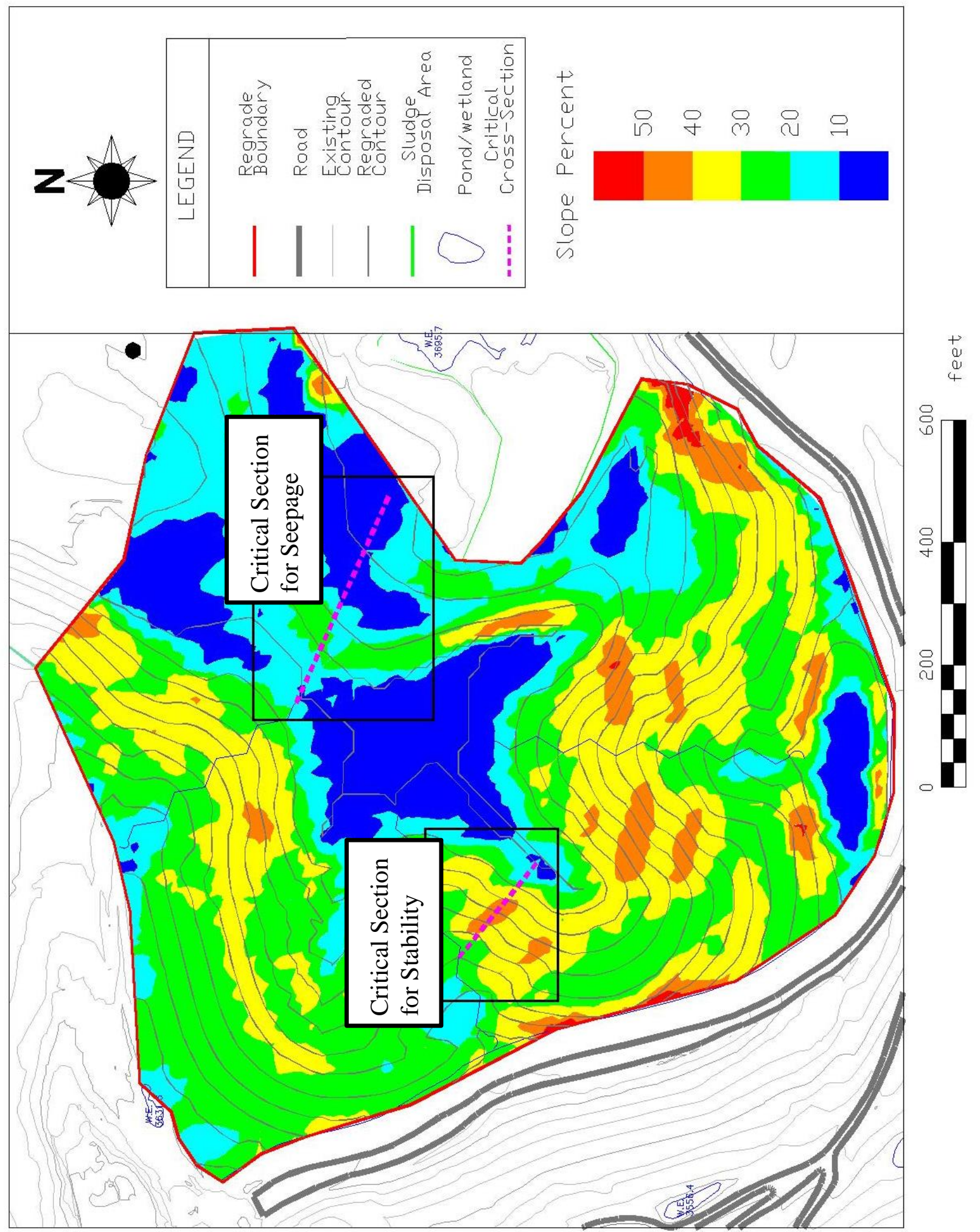

Figure 5.16: Slope analysis and critical slope of design iteration 3 


\subsection{1) Stability Modeling}

Modeling was completed within the SVSlope ${ }^{\mathrm{TM}}$ program to evaluate the stability of the critical slope within this design iteration. As with the second design iteration the multilayer cap design was completed with the hydraulic barrier layer constructed in benches. The bottom of the drainage layer was then constructed to fill the benches with its top forming the geomorphic profile. The cross-section of the slope (with units of feet) is given in Figure 5.17.

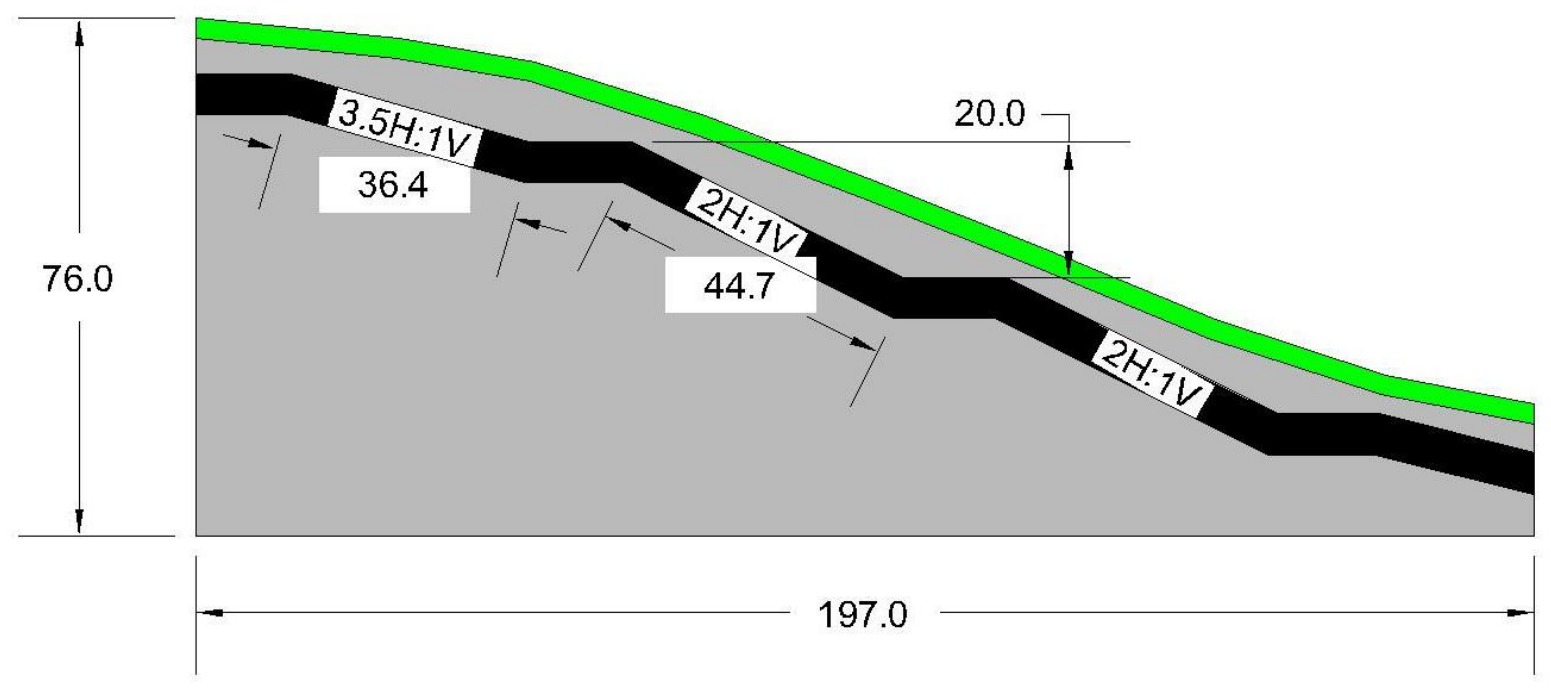

Figure 5.17: Cross-section of slope modeled on design iteration 3 (units in feet)

The geometry was input to SVSlope ${ }^{\mathrm{TM}}$ and the soil properties determined in section 4.2.3 were applied to each layer. The program was used to create 1000 potential failure surfaces in the slope and each was analyzed with the GLE method. A minimum factor of safety of 1.895 was determined for the slope. Figure 5.18 shows the model output results for this design iteration. 


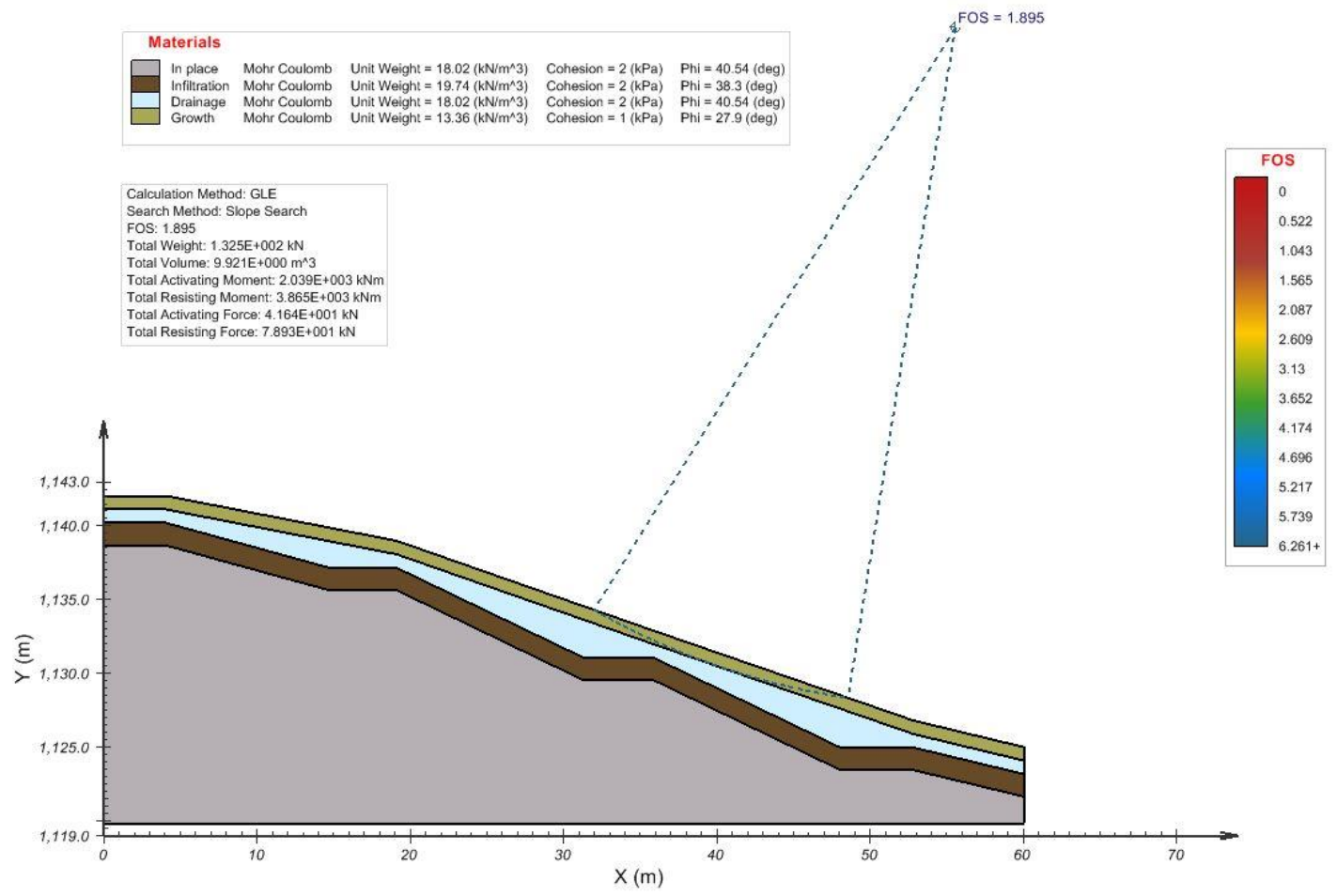

Figure 5.18: Slope stability analysis for slope modeled on design iteration 3

The minimum factor of safety for this slope fell above the minimum threshold of 1.5 meaning that this construction is stable and compliant for construction. While several of the underlying benches within the hydraulic barrier layer are at a slope of $2 \mathrm{H}: 1 \mathrm{~V}$, the multilayer design allows the growth layer to remain at a stable slope. Like the previous design iterations, the critical failure plane was located within the growth layer composed of the Shale/MGro ${ }^{\mathrm{TM}}$ blend.

\subsection{2) Seepage Analysis}

Following stability modeling, the next step in analyzing this reclamation alternative was the seepage modeling to evaluate the performance of the multilayer cap and cover design system. As the critical slope of the design was indicated to be stable, a full range of seepage of tests were applied to slopes from this design. Both the stability and seepage critical slopes were modeled for seepage performance over the long-term and for a single heavy rainfall event (100-year, 24hour design storm).

\section{Long-term performance}

The long-term performance of the cap and cover system for design iteration 3 was modeled in the same manner as the other designs. A constant infiltration of $0.00204 \mathrm{~m} / \mathrm{d}$ (55\% of average daily precipitation) was applied to the outer surface of the slope for a two year time period and the flow out of each layer was measured out of the toe of the slope using flux lines. The percentage of flow above the hydraulic barrier was compared to the total outflow to measure the efficiency of the cover. 
Steep Slope

The first slope modeled was the steep slope which was critical for slope stability. Results for the model are shown in Figure 5.19.

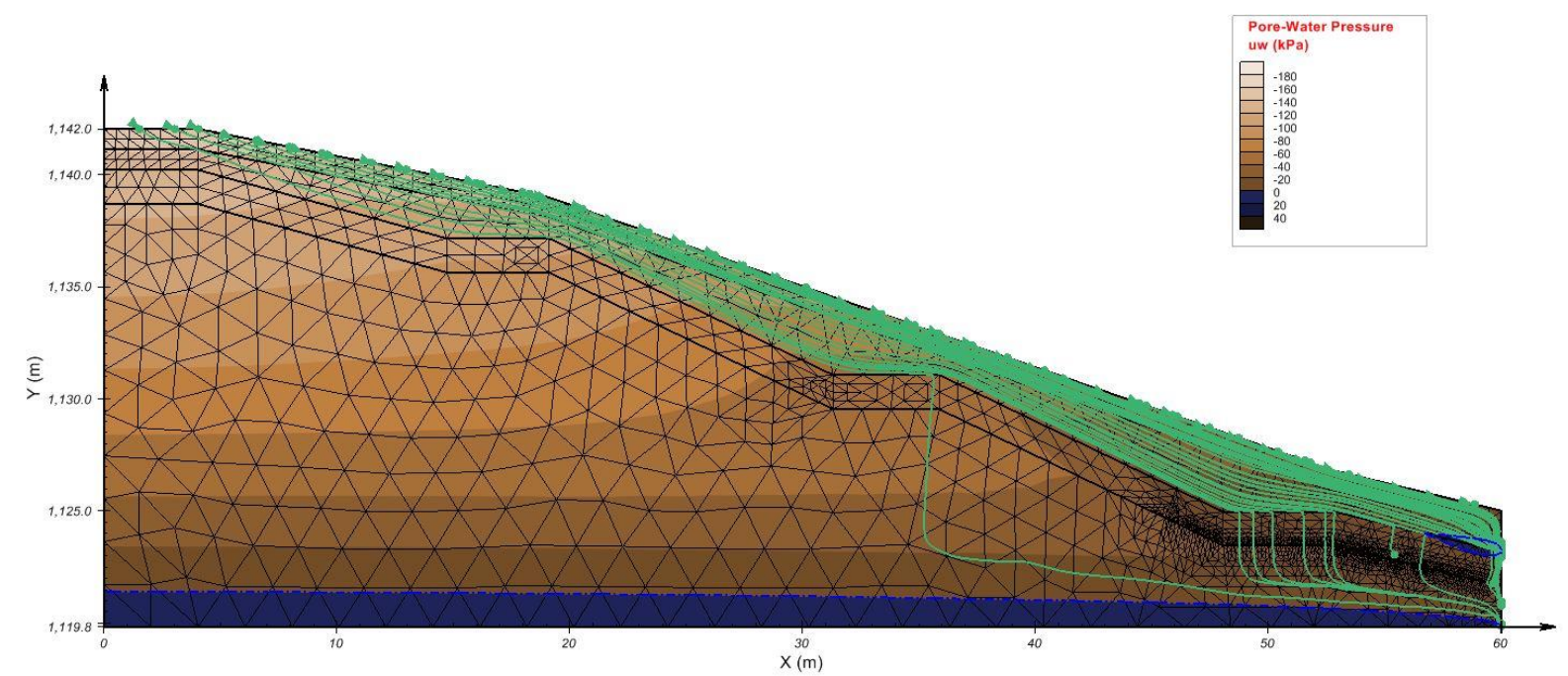

Figure 5.19: Two-year seepage results for iteration 3 steep slope

The streamlines in Figure 5.19 show that a significant amount of infiltration through the hydraulic barrier is occurring across the bench on the barrier layer nearest the toe of the slope. To further explore this potential, flowlines and the slope degree of saturation were plotted as shown in Figure 5.20 and Figure 5.21.

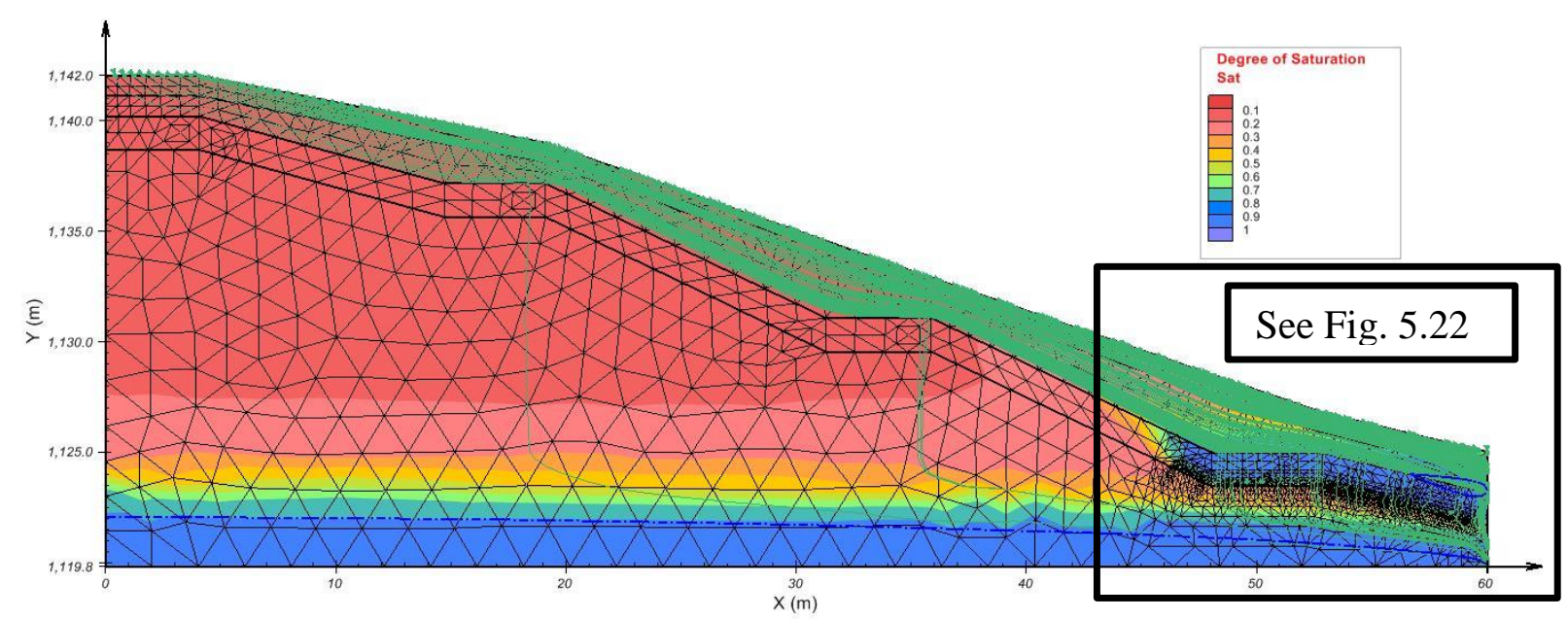

Figure 5.20: Iteration 3 slope degree of saturation and flow streamlines 


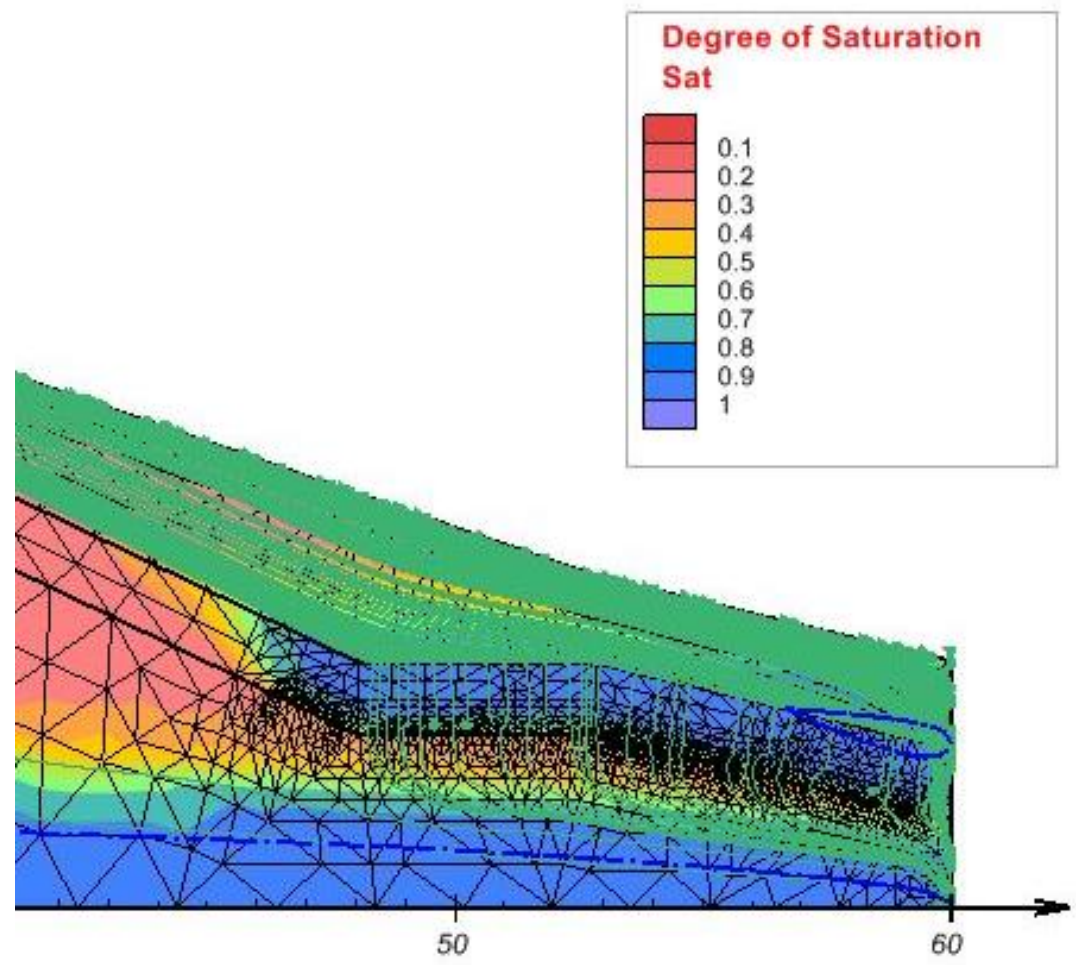

Figure 5.21: Close-up of Iteration 3 slope toe

Plotting the degree of saturation showed that the hydraulic barrier was becoming nearly completely saturated on the bench nearest the toe of the slope and a majority of the streamlines passing through the barrier were doing so at this point. The installation of an internal slope drain was proposed as a solution to this problem. The drain would capture seepage within the drainage layer at this point and quickly remove it from the slope. As the critical location to capture the seepage was shown to be above the lowest bench in the barrier layer, this is the location where the drain was proposed to be installed as shown in Figure 5.22. Flowlines upslope of the lowest bench likely indicate mathematically placed low-flow paths as described in section 4.4.

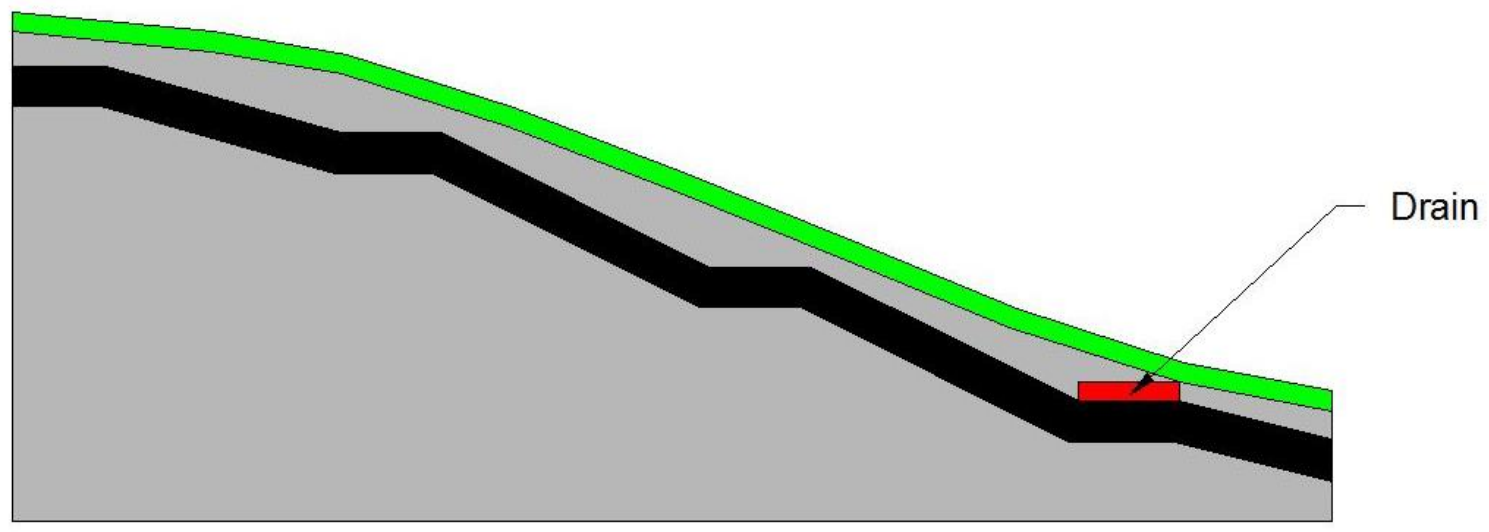

Figure 5.22: Proposed drain location for iteration 3 steep slope 
To measure the effectiveness of this drain, an additional flux line was placed in the model across the top of the hydraulic barrier at the bottom bench to measure the flow across the barrier. This flow was assumed to be collected by an internal drain and removed along with the rest of the flow above the barrier layer. The results of this model were then compared to the base case without the drain. Results from the models are given in Table 5.4. Installation of the drain was estimated to increase the effectiveness of the hydraulic barrier layer and increase the percentage of seepage above the hydraulic barrier nearly $10 \%$ from $74 \%$ to $84 \%$.

Table 5.4: Summary of seepage results for iteration 3 steep slope

\begin{tabular}{|c|c|c|}
\hline Layer & $\begin{array}{c}\text { Percentage of total } \\
\text { outflow }\end{array}$ & $\begin{array}{c}\text { Estimated percentage of } \\
\text { total outflow with } \\
\text { installation of drain on } \\
\text { bottom bench }\end{array}$ \\
\hline Growth Layer & 3.17 & 3.17 \\
\hline Drainage Layer & 70.68 & 80.58 \\
\hline Hydraulic Barrier & 0.14 & 0.14 \\
\hline Fill material & 26.01 & 16.12 \\
\hline $\begin{array}{c}\text { TOTAL FLOW ABOVE } \\
\text { BARRIER }\end{array}$ & 73.85 & 83.75 \\
\hline
\end{tabular}

\section{Shallow Slope}

It is expected that a shallower slope will be more critical to the performance of the cap and cover design. With less slope, water will move more slowly through the soil, perhaps leading to the saturation of the hydraulic barrier and a decrease in performance. To evaluate the performance of the cap and cover system on this shallow slope, the same testing procedure was used as with the steeper slope. A cross-section of the slope was evaluated in SVFlux ${ }^{\mathrm{TM}}$ and the percentage of flow above the hydraulic barrier was computed with respect to the total outflow. The results of the seepage modeling are given in Figure 5.23, Figure 5.24 and Table 5.5.

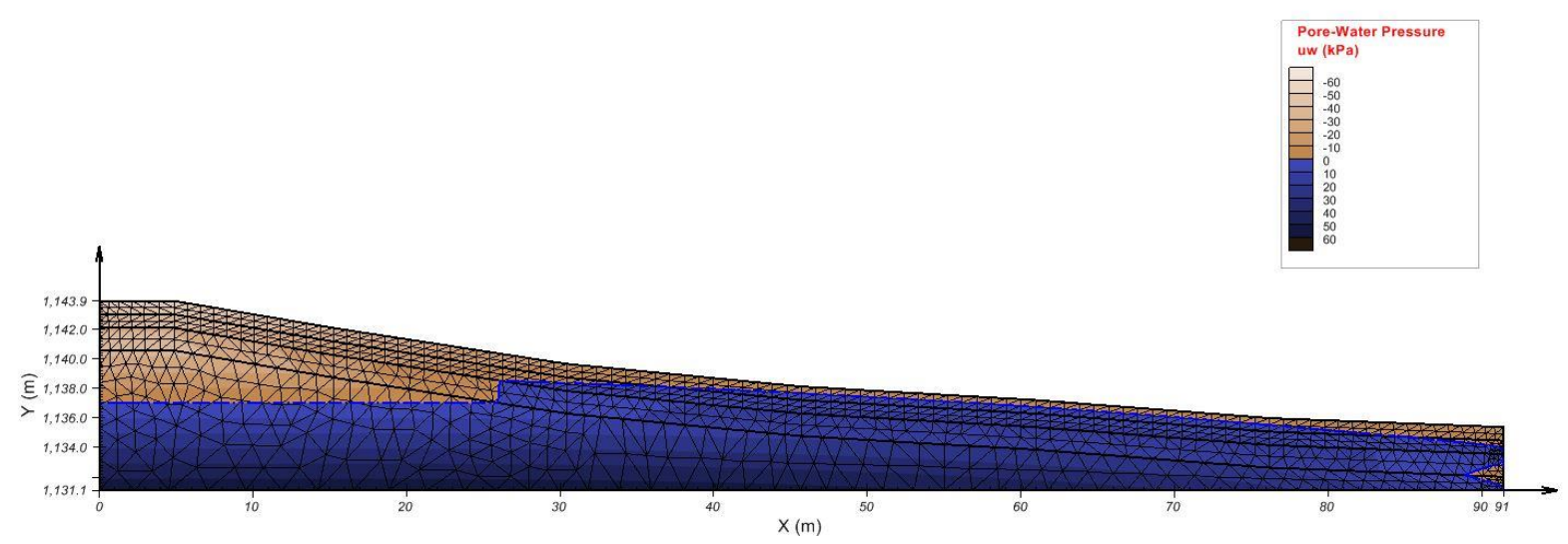

Figure 5.23: Seepage model pore pressure for shallow slope of iteration 3 


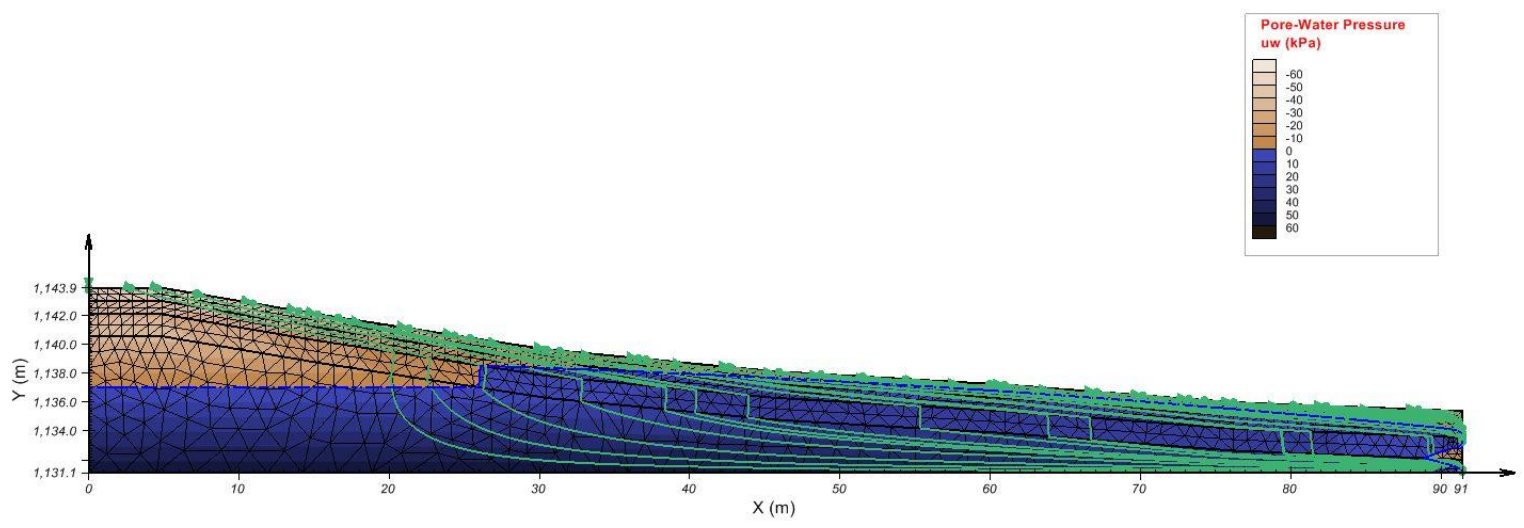

Figure 5.24: Seepage model flowpaths for shallow slope of iteration 3

Table 5.5: Summary of seepage results from shallow slope of iteration 3

\begin{tabular}{|c|c|}
\hline Layer & $\begin{array}{c}\text { Percentage of total } \\
\text { outflow }\end{array}$ \\
\hline Growth Layer & 3.21 \\
\hline Drainage Layer & 59.47 \\
\hline Hydraulic Barrier & 0.22 \\
\hline Fill material & 37.11 \\
\hline TOTAL FLOW ABOVE & 62.67 \\
\hline BARRIER & \\
\hline
\end{tabular}

The performance of the cover system on the shallow slope is not as effective as the steep slope. Only about $63 \%$ of the flow is above the hydraulic barrier and as seen in Figure 5.23 much of the slope is saturated after the 2-year model time. There is pore pressure build-up throughout the slope.

\section{Design storm performance}

Maltby (2005) describes the failure of several landfill cover designs involving the use of paper mill residuals, similar to the $\mathrm{MGro}^{\mathrm{TM}}$ proposed for this site. The primary cause of failure was typically sloughing in the residuals after a heavy rainfall event. To determine if a heavy rainfall event is a threat to the stability of the slopes of design iteration 3 , analysis was performed for a 100-year, 24-hour design storm at the Royal Scot site. An assumed infiltration of this rainfall of 5.38 inches $(13.67 \mathrm{~cm})(\mathrm{NOAA}, 2015)$ was put into model over a 24-hour period using the precipitation manager function of SVFlux ${ }^{\mathrm{TM}}$. After the model was run, the seepage and stability were reevaluated to assess the overall performance of the design. For each model, the initial saturation conditions were set equal to the final saturation from the 2-year long-term analysis.

\section{Steep Slope}

Few adverse effects from the 100-year, 24-hour storm were observed on the steep slope. As seen in Figure 5.25, there is little pore pressure build-up in the cap even at the conclusion of the heavy 
rain of the design storm. The buildup present at the toe does not have any significant impact on the stability of the slope as illustrated in Figure 5.26 with a factor of safety of 1.895 and does not saturate the hydraulic barrier layer, which would compromise its performance.

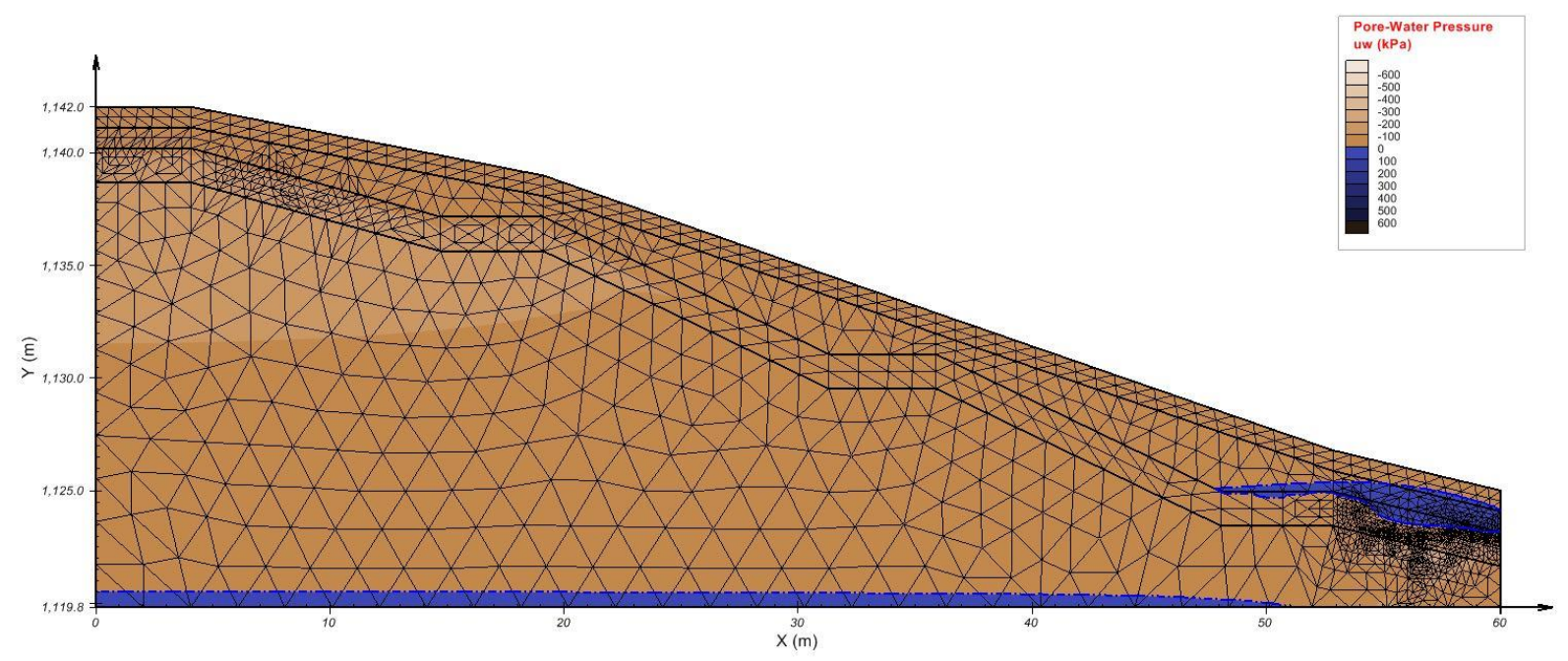

Figure 5.25: Seepage model results for steep slope immediately after 100-year, 24-hour design storm

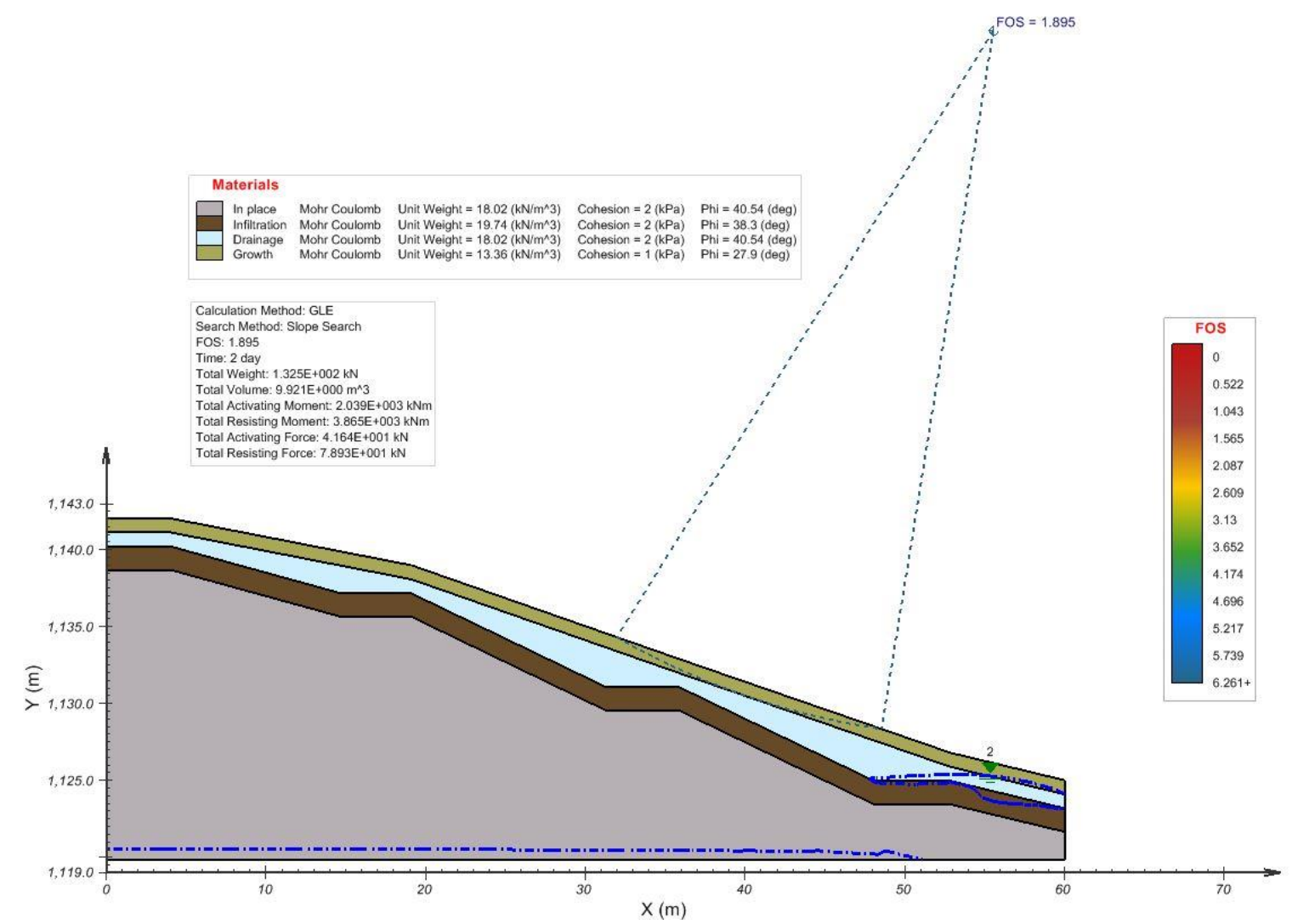

Figure 5.26: Stability model results for steep slope immediately after 100-year, 24-hour design storm 


\section{Shallow Slope}

At the conclusion of the 100-year, 24-hour design storm (Figure 5.27), there is significant pore pressure buildup throughout the slope, and especially above the hydraulic barrier layer at approximately $\mathrm{x}=50 \mathrm{~m}$. The pore pressure accumulation leads to the slope failing as illustrated in Figure 5.28 with the factor of safety dropping to 0.22 . After the rain has stopped for one day, the slope drains, the pore pressure reduces and stability is once again indicated. Figure 5.29 shows the slope after the one day drain time and the stable factor of safety of 4.485 . These results are not favorable, as they indicate the slope will fail after a heavy rainfall.

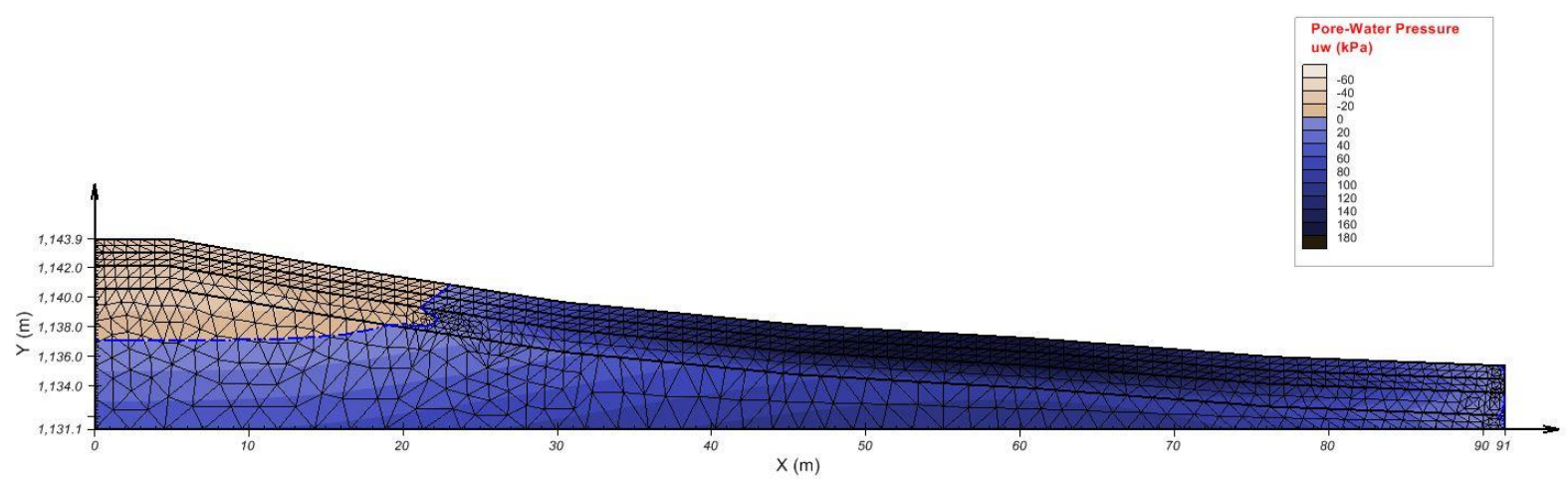

Figure 5.27: Seepage model results for shallow slope immediately after 100-year, 24-hour storm

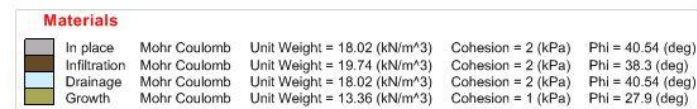

Calculation Method: GLE Search Method: Slope Search FOS: 0.220

Total Weight: $4.362 \mathrm{E}+001 \mathrm{kN}$ Total Volume: $3.102 \mathrm{E}-001 \mathrm{~m}^{\wedge} 3$ Total Activating Moment: $4.046 \mathrm{E}+002 \mathrm{kN}$ Total Resisting Moment. $8.921 E+001 \mathrm{kN}$ Total Activatiting Force: $3.674 \mathrm{E}+001 \mathrm{kN}$
Total Resisting Force: $8.080 \mathrm{E}+000 \mathrm{kN}$

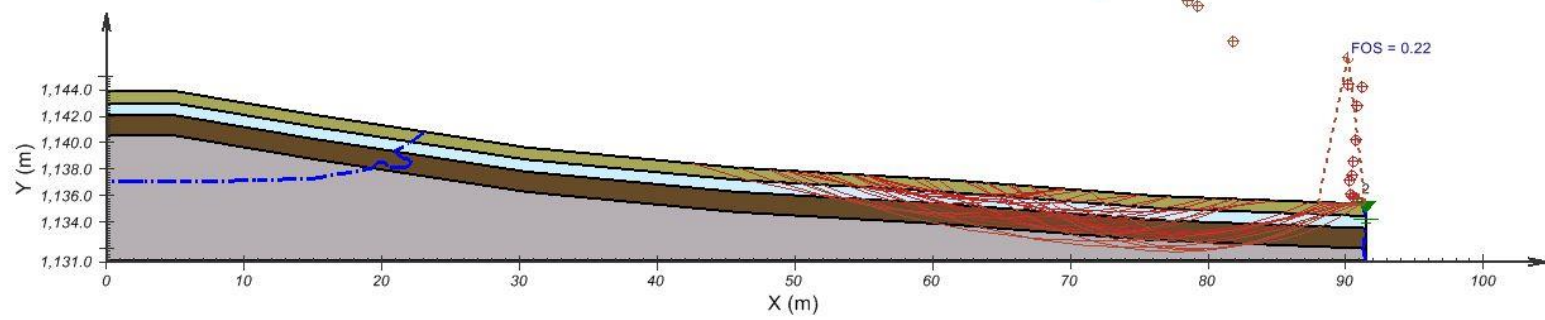

Figure 5.28: Stability model results for shallow slope immediately after 100-year, 24-hour storm (surfaces with FS<1.5 shown) 


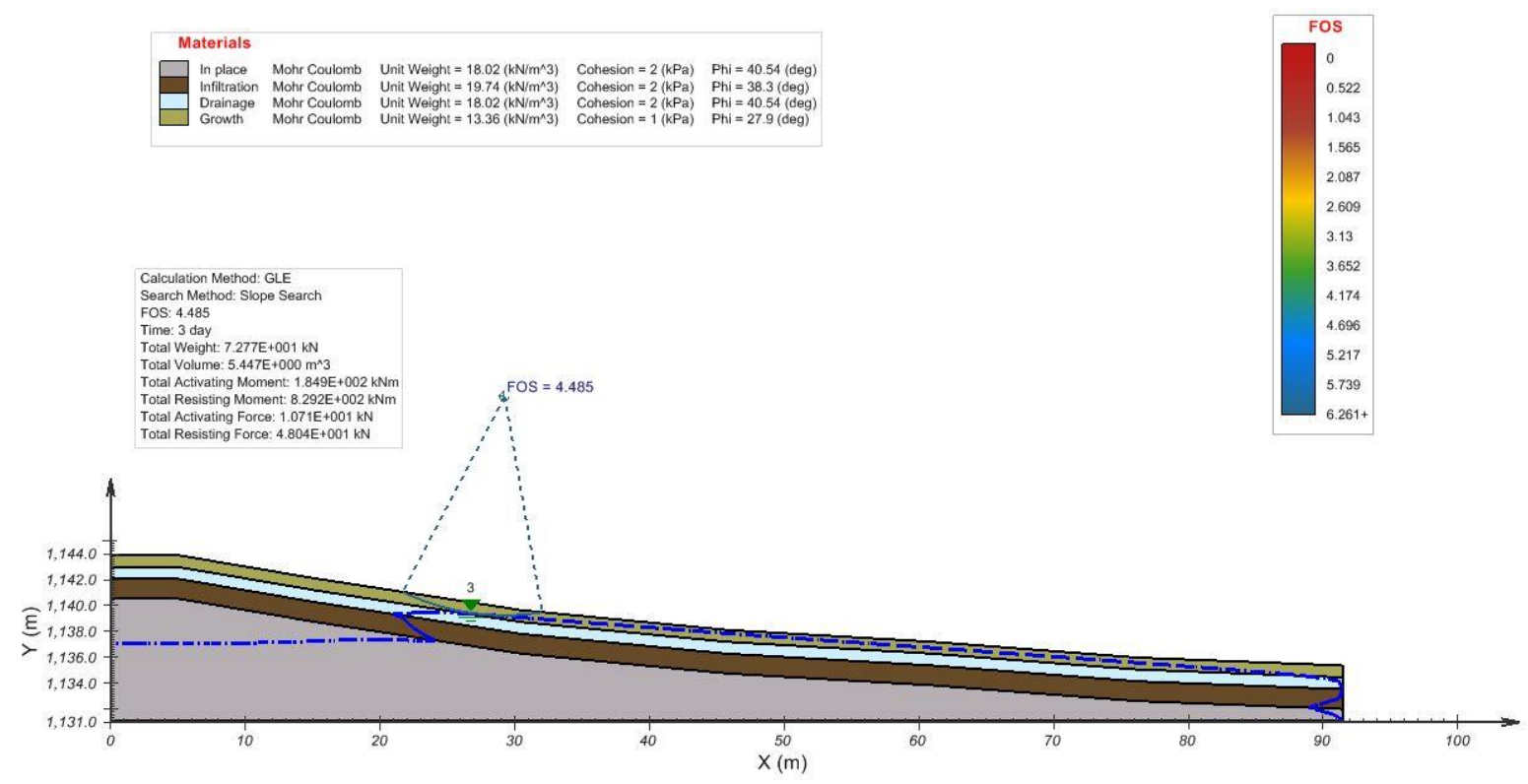

Figure 5.29: Stability model results for shallow slope one day after 100-year, 24-hour storm

\section{5) Conclusions and discussion}

Several conclusions could be reached from the analysis of the three reclamation design iterations of the Royal Scot site. Each design used the multi-layer cap and cover system designed in Chapter 4 and variations of the slope had significant impacts on the stability and performance of that cover.

Steeper slopes offered the best seepage removal performance, as illustrated by design Iteration 2 and the steep slope of design Iteration 3. However, slopes needed to be reduced in steepness such that the surface growth layer was at or under a $2.5 \mathrm{H}$ to $1 \mathrm{~V}$ ratio in order to meet the stability requirements given the material properties selected in Section 4.2.

Design Iteration 3 was designed such that its critical slope was at the steepest angle that maintained acceptable stability, a factor of safety above 1.50. This slope, consisting of a benched hydraulic barrier layer overlain by the drainage and growth layers kept approximately $74 \%$ of infiltration flow above the fill material. It was determined that the cap performance could be enhanced by the addition of a drain added to the slope's lowest internal bench which would keep nearly $84 \%$ of infiltration flow above the fill. The critical slope also saw little impact from a 100year, 24-hour design storm and maintained its drainage and stability under those conditions.

Analysis of one of the shallowest slopes on the design did not yield favorable results. The cap and cover system was less effective, with only $63 \%$ of infiltration flow above the fill.

Furthermore, significant pore pressures built up in the slope after the heavy rainfall of the 100year, 24-hour design storm leading to slope failure. These shallow slopes should be avoided as 
possible in reclamation designs and internal drains should be installed to reduce the pore pressure accumulation.

Based on the results from all of the design iterations, and especially the design storm analysis on iteration 3, it is recommended that slopes are kept as close to the $2.5 \mathrm{H}$ to $1 \mathrm{~V}$ ratio as possible. While shallower slopes do offer better stability, they reduce the effectiveness of the multi-layer cap and cover system and allow more infiltration into the fill material (and consequently, more acid-mine drainage generation). Shallow slopes also saturate more easily after a heavy rainfall and this will lead to accumulation of pore pressure and slope failure. These findings, and the supporting modeling results are summarized in Table 5.6.

Table 5.6: Decision table with Chapter 5 modeling summary

\begin{tabular}{|c|c|c|c|c|c|c|}
\hline Design & $\begin{array}{c}\text { Factor of } \\
\text { Safety } \\
\text { (seepage not } \\
\text { considered) }\end{array}$ & $\begin{array}{c}\text { Meets } \\
\text { Geotechnical } \\
\text { Stability } \\
\text { Requirements? } \\
\text { (FS } \geq 1.5 \text { ) }\end{array}$ & $\begin{array}{c}\text { Seepage } \\
\text { Reduction } \\
\text { Performance } \\
\text { (\% of seepage } \\
\text { captured } \\
\text { above fill) }\end{array}$ & $\begin{array}{l}\text { Reclamation } \\
\text { Benefits }\end{array}$ & $\begin{array}{c}\text { Estimated } \\
\text { Earthmoving } \\
\text { Requirements } \\
\left(\mathbf{m}^{\mathbf{3}}\right)\end{array}$ & $\begin{array}{l}\text { 100 year, } 24- \\
\text { hour design } \\
\text { storm } \\
\text { performance }\end{array}$ \\
\hline $\begin{array}{c}\text { \# } 1 \text { Conventional } \\
\text { Benched }\end{array}$ & 1.71 & Yes & $72 \%$ & $\begin{array}{l}\text { Cap is applied } \\
\text { and vegetated, } \\
\text { no geomorphic } \\
\text { attributes }\end{array}$ & 149,000 & Not tested \\
\hline $\begin{array}{l}\text { \# } 2 \text { Geomorphic } \\
\text { Landform } 1\end{array}$ & 1.21 & No & $93 \%$ & $\begin{array}{l}\text { Cap applied and } \\
\text { vegetated, } \\
\text { geomorphic } \\
\text { landform with } 4 \\
\text { stream channels } \\
\text { created }\end{array}$ & 248,480 & Not tested \\
\hline \multicolumn{4}{|l|}{$\begin{array}{c}\text { \# } 3 \text { Geomorphic } \\
\text { Landform } 2 \\
\end{array}$} & \multirow{4}{*}{$\begin{array}{l}\text { Cap applied and } \\
\text { vegetated, } \\
\text { geomorphic } \\
\text { landform with } 3 \\
\text { stream channels } \\
\text { created }\end{array}$} & \multirow{4}{*}{191,000} & \\
\hline Steep Slope & 1.9 & Yes & $73.90 \%$ & & & $\begin{array}{c}\text { Favorable, little } \\
\text { pore pressure } \\
\text { accumulation } \\
\text { observed and no } \\
\text { significant } \\
\text { decrease in } \\
\text { factor of safety }\end{array}$ \\
\hline $\begin{array}{c}\text { Steep Slope with } \\
\text { internal drain }\end{array}$ & 1.9 & Yes & $83.80 \%$ & & & Not tested \\
\hline Shallow Slope & 4.49 & Yes & $62.70 \%$ & & & $\begin{array}{c}\text { Unfavorable, } \\
\text { significant pore } \\
\text { pressure } \\
\text { accumulation } \\
\text { and decrease of } \\
\text { Factor of Safety } \\
\text { to } 0.20 \\
\text { immediately } \\
\text { after storm }\end{array}$ \\
\hline
\end{tabular}




\section{6) CONCLUSIONS AND RECOMMENDATIONS}

This research yielded three primary outcomes. First, the geotechnical properties of the coarse coal refuse shale and $\mathrm{MGro}^{\mathrm{TM}}$ short paper fiber materials were fully defined through laboratory testing. Second, a cap and cover system was designed to cover the fill material while maintaining geotechnical stability and preventing infiltration from reaching the fill. Third, the designed cap and cover system was applied to three reclamation alternatives where its seepage performance and geotechnical stability were evaluated through the use of finite-element computer modeling.

\section{1) Outcome 1: Geotechnical Material Properties}

Geotechnical testing was completed on the coarse coal refuse shale, MGro ${ }^{\mathrm{TM}}$ short paper fiber, and two blends of these materials. Key parameters of these materials obtained from these materials included the grain size distribution, specific gravity, maximum dry unit weight and optimum moisture content, effective internal angle of friction, cohesion, and hydraulic conductivity. Several of the important findings were:

- When the two materials were blended by volume (80\% shale $/ 20 \% \mathrm{MGro}^{\mathrm{TM}}$ and $60 \%$ shale $/ 40 \% \mathrm{MGro}^{\mathrm{TM}}$ ) the combined grain size distribution followed the shale distribution

- As more $\mathrm{MGro}^{\mathrm{TM}}$ was added to the blended material, the maximum unit weight decreased and the optimum moisture content increased.

- The calculated effective angle of internal friction range of 40-45 degrees was outside the upper boundary of literature values which ranged from 27-40 degrees.

- The 60/40 blend of shale and MGro ${ }^{\mathrm{TM}}$ achieved an effective angle of friction of approximately 30 degrees.

- The hydraulic conductivity of the shale was very low at high compaction energies, with a $2.29 \times 10^{-7} \mathrm{~cm} / \mathrm{s}$ value at a standard proctor compaction.

- Creation of fine particles in the shale was indicated by the testing. Aggregation of the particles prevented this from being quantified in the post-permeability grain-size distribution. However, the low hydraulic conductivities measured on highly compacted specimens and the increase in cohesion as compaction was increased indicated an increased presence of fine particles.

\section{2) Outcome 2: Cap and Cover system design}

A multi-layer cap and cover system following recommendations and regulations from the United States Environmental Protection Agency and West Virginia Department of Environmental Protection was designed for the Royal Scot site. The effects of the geotechnical input parameters, slope steepness, and hydraulic barrier thickness were investigated. The modeling was completed using the SVSlope/SVFlux finite element computer modeling software on a slope 50 feet $(15.24 \mathrm{~m})$ tall. Important findings and recommendations are:

- With the selected geotechnical input parameters, the minimum acceptable slope stability factor of safety of 1.5 was not met for the cap and cover sloped at $2 \mathrm{H}: 1 \mathrm{~V}$ (26.8 degrees). The stability requirement was satisfied when the cap and cover slope was reduced to 2.5H:1V (21.8 degrees). 
- At the lowest modeled hydraulic conductivity $\left(2 \times 10^{-7} \mathrm{~cm} / \mathrm{s}\right)$, all modeled barrier layer thicknesses $(0.305-1.525 \mathrm{~m})$ were effective in keeping approximately $90 \%$ of infiltration out of the coal refuse fill. At the medium hydraulic conductivity $\left(2 \times 10^{-6} \mathrm{~cm} / \mathrm{s}\right)$, only thicknesses exceeding $0.915 \mathrm{~m}$ kept the over $85 \%$ of the infiltration above the fill. At the highest modeled hydraulic conductivity, all modeled hydraulic barrier thicknesses were ineffective and a thickness increase to $3.048 \mathrm{~m}$ was required to keep approximately $20 \%$ of the infiltration above the fill.

- Based on the modeling, design recommendations were made:

○ Maximum slope: $2.5 \mathrm{H}: 1 \mathrm{~V}$ (21.8 degrees)

○ Minimum hydraulic barrier thickness: $0.915 \mathrm{~m}$

○ Target maximum hydraulic conductivity: $10^{-6} \mathrm{~cm} / \mathrm{s}$

\section{3) Outcome 3: Application to Reclamation Alternatives}

A cap and cover system satisfying the design recommendations was applied to three reclamation

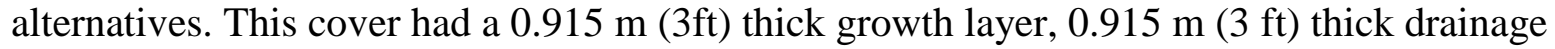

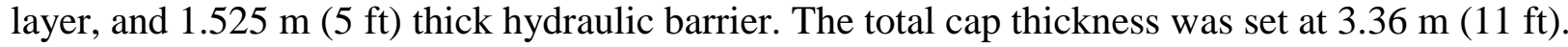
The slope stability and seepage performance were evaluated on at least one critical slope of each design. Following analysis of each design, recommendations were made. The findings of this section are based on the decision table in Section 5.5 (Table 5.6):

- Application of the cover system to the conventional bench sloped reclamation design resulted in a slope that satisfied stability requirements and seepage reduction of over $70 \%$. Vegetative cover would be applied to the area, but no geomorphic benefits would be observed and no stream channels replicating natural form would be created. This design has the lowest earthmoving requirements of the alternatives.

- A geomorphic design with slopes less than $21.8^{\circ}$ met stability requirements and offered significant seepage reduction of approximately $74 \%$. The addition of a drain structure on an underlying bench near the toe of the slope increased the seepage reduction by $10 \%$ to $84 \%$. The design had more earthmoving required than the conventional design, but offered geomorphic benefits and created 3 stream channels.

- When subjected to a 100-year, 24-hour design storm, the steeper slope on geomorphic landform 2 was able to successfully drain and no significant decrease in strength due to pore pressure accumulation was observed. The shallow slope did not drain, and as a result, pore pressure accumulation led to a significant reduction in strength and slope failure.

\section{4) Final Recommendations}

Based on the results of this study, the application of a multi-layer cap and cover design to a geomorphic design is feasible. A design like geomorphic alternative 2, which minimizes steep slopes in excess of $2.5 \mathrm{H}: 1 \mathrm{~V}$ and maintains the creation of geomorphic landform features and stream channels offers significant benefits. In addition to the stability, aesthetic, and erosion benefits summarized in literature for geomorphic landforms, this design includes increased geotechnical stability and seepage control from the engineered cap and cover system. With a cap 
and cover system including a compacted shale hydraulic barrier at least $1.525 \mathrm{~m}$ thick and maximum hydraulic conductivity of $10^{-6} \mathrm{~cm} / \mathrm{s}$, a typical slope on this design can keep approximately $74 \%$ of infiltration from precipitation from entering the fill material. The addition of one bench drain above the toe can increase the efficiency by nearly $10 \%$ for a total reduction of $84 \%$.

Modeling indicated a tradeoff between slope and stability and seepage performance. Steep slopes offer a lower geotechnical stability (as indicated by a lower factor of safety) and greater seepage performance. Shallow slopes achieve a greater factor of safety for geotechnical stability, but reduced seepage reduction performance. In the final design, slopes should be maintained as close to the $2.5 \mathrm{H}: 1 \mathrm{~V}$ ratio as possible. Steeper slopes were proven to not achieve acceptable geotechnical stability and shallower have reduced seepage performance. Additionally, drains should be installed on at least the internal bench above the toe of the slope. These structures offer significant benefits to the overall seepage performance of the cover system and a pathway for drainage in storm events to reduce the accumulation of pore pressure. 


\section{REFERENCES}

ASTM Designation D422. (2007). "Standard Test Method for Particle-Size Analysis of Soils." Annual Book of ASTM Standards, American Society of Testing Materials, Easton, MD.

ASTM Designation D698. (2007). "Standard Test Methods for Laboratory Compaction Characteristics of Soil Using Standard Effort $\left(12400 \mathrm{ft}-\mathrm{lbf} / \mathrm{ft}^{3}\left(600 \mathrm{KN}-\mathrm{m} / \mathrm{m}^{3}\right)\right)$." Annual Book of ASTM Standards, American Society of Testing Materials, Easton, MD.

ASTM Designation D2216. (2010). "Standard Test Methods for Laboratory Determination of Water (Moisture) Content of Soil and Rock by Mass." Annual Book of ASTM Standards, American Society of Testing Materials, Easton, MD.

ASTM Designation D2487. (2010). "Standard Practice for Classification of Soils for Engineering Purposes (Unified Soil Classification System).” Annual Book of ASTM Standards, American Society of Testing Materials, Easton, MD.

ASTM Designation D3080. (2007). "Standard Test Methods for Direct Shear Test of Soils Under Consolidated Drained Conditions." Annual Book of ASTM Standards, American Society of Testing Materials, Easton, MD

ASTM Designation D4318. (2007). "Standard Test Methods for Liquid Limit, Plastic Limit, and Plasticity Index of Soils." Annual Book of ASTM Standards, American Society of Testing Materials, Easton, MD

ASTM Designation D4767. (2011). "Standard Test Method for Consolidated Undrained Triaxial Compression Test for Cohesive Soils." Annual Book of ASTM Standards, American Society of Testing Materials, Easton, MD

ASTM Designation D5084. (2010). "Standard Test Methods for Measurement of Hydraulic Conductivity of Saturated Porous Materials Using a Flexible Wall Permeameter." Annual Book of ASTM Standards, American Society of Testing Materials, Easton, MD

Bonaparte, R., Gross, B.A., Daniel, D.E., Koerner, R.M., and Dwyer, S. (2004). "EPA (Draft) Technical Guidance for RCRA/CERCLA Final Covers" United States Environmental Protection Agency, Office of Solid Waste and Emergency Response. Washington, D.C.

Bugosh N., 2004, "Computerizing the fluvial geomorphic approach to land reclamation," National Meeting of the American Society of Mining and Reclamation and The 25th WV Surface Mine Drainage Task Force, April 18-24, pp. 240-258. 
Bugosh, N. (2006). Basic manual for fluvial geomorphic review of landform designs. United States Department of the Interior Office of Surface Mining Reclamation and Enforcement (OSMRE), Denver, CO, 36 p.

Bugosh, N. (2009). "A summary of some land surface and water quality monitoring results for constructed GeoFluv landforms." Proc., Joint Conference of the $26^{\text {th }}$ Annual Meetings of the American Society of Mining and Reclamation (ASMR) and $11^{\text {th }}$ Billings Land Reclamation Symposium, ASMR, Lexington, KY, 153-175.

Camberato, J. J., Gagnon, B., Angers, D. A., Chantigny, M. H., \& Pan, W. L. (2006). Pulp and paper mill by-products as soil amendments and plant nutrient sources. Canadian journal of soil science, 86(4), 641-653.

Carlson Software Inc., and Bugosh, N. (2005). Fluvial Geomorphic Landscape Design Computer Software. US Patent Office, publication number WO/2005/036331, international application number PCT/US2004/02995.

Carpenter, A. F., \& Fernandez, I. J. (2000). "Pulp sludge as a component in manufactured topsoil”. Journal of environmental quality, 29(2), 387-397.

“Closure Criteria” 40 C.F.R 258.60. (1997).

D’Appolonia Consulting Engineers Inc, 2009. Engineering and Design Manual Coal Refuse Disposal Facilities, second ed. U.S. Department of Labor, Mine Safety and Health Administration [MSHA].

Daniels, W. L., Stewart, B. R., \& Dove, D. C. (1995). "Reclamation of coal refuse disposal areas". Va. Coop. Ext. Pub, 460, 131.

Daniels, W.L., Haering, K., Evanylo, G., Burger J., \& Beck, M. (2013). “Suitability of MeadWestVaco residuals for utilization as soil amendments on reclaimed mined lands and native soils" Final Report Virginia Tech Department of Crop \& Soil Environmental Sciences

Das, Braja M. (2010). Principles of Geotechnical Engineering ( $8^{\text {th }}$ ed.). Canada: Nelson Education Ltd.

DePriest, Nathan C. (2015). "Assessing the conceptual design, groundwater movement, and contaminant desorption of geomorphic landform design as an alternative for conventional valley fill surface mine reclamation." Doctoral Dissertation, West Virginia University Morgantown, WV

DePriest, N.C., Hopkinson, L.C., Quaranta, J.D., and Ziemkiewicz, P.F. (2015). “Geomorphic landform design alternatives for an existing valley fill in central Appalachia, USA: Quantifying the key issues." Ecological Engineering, 81, 19-29. 
Duncan, J. M. (2000). "Factors of safety and reliability in geotechnical engineering." Journal of geotechnical and geoenvironmental engineering, 126(4), 307-316.

Evans, K.G. and Willgoose, G.R. (2000). "Post-mining landform evolution modeling: 2. Effects of vegetation and surface ripping." Earth Surface Processes and Landforms, 25, 803-823.

Fredlund, M. (2009) SVOffice ${ }^{T M}$ 2009. Available from: http://www.soilvision.com/svoffice2009download.php

Fredlund, D.G., Krahn, J., Pufahl, D.E. (1981). "The Relationship between Limit Equilibrium Slope Stability Methods". Proceedings of the International Conference on Soil Mechanics And Foundation Engineering, Vol. 3. 409-416.

Fredlund, D.G., and Xing, A. (1994). "Equations for the soil-water characteristic curve." Canadian Geotechnical Journal, 31(3), 521-532.

Fredlund, D.G., Xing, A., and Huang, S.Y. (1994). "Predicting the permeability function for unsaturated soils using the soil-water characteristic curve." Canadian Geotechnical Journal, 31(4), 533-546.

Hegazy, Y. A., Cushing, A. G., \& Lewis, C. J. (2004). Physical, Mechanical and Hydraulic Properties of Coal Refuse for Slurry Impoundment Design. D'Appolonia Engineering, Monroeville, PA.

Kulbacki, Michael A. (2014). "Slope stability and alternative design methodology for highway rock cut slopes in West Virginia." M.S. Thesis, West Virginia University, Morgantown, WV

Laubenstein, J. W., \& Field, S. (1994). "Utilization of Short Paper Fiber (SPF) in the Manufacturing of Synthetic Soils Used for Capping Landfills". TAPPI International Environmental Conference, 355-355

Laubenstein, J. (2004). "Beneficial use of short paper fiber (paper mill sludge) for pollution prevention in the mining industry." TAPPI Paper Summit-Spring Technical and International Environmental Conference.

Maltby, V. (2005). "Compilation of alternative landfill cover experience using wastewater treatment plant residuals". National Council for Air and Stream Improvement Inc. (NCASI) Technical Bulletin No. 900.

Martin-Duque, J.F., Pedraza, J., Diez, A., Sanz, M.A., and Carrasco, R.M. (1998). “A geomorphological design for the rehabilitation of an abandoned sand quarry in central Spain." Landscape and Urban Planning, 42(1), 1-14. 
Martin-Duque, J.F., Sanz, M.A., Bodoque, J.M., Lucia, A., and Martin-Moreno, C. (2010). "Restoring earth surface processes through landform design. A 13-year monitoring of a geomorphic reclamation model for quarries on slopes." Earth Surface Processes and Landforms, 35(5), 531-548.

Martin-Moreno, C., Martin-Duque, J.F., Nicolau, J.M., Sanchez, L., Ruiz, R., Sanze, M.A., Lucia, A., and Zapico, I. (2008). "A geomorphic approach for the ecological restoration of kaolin mines at the Upper Tagus Natural Park (Spain)." Proc., $6^{\text {th }}$ European Conference on Ecological Restoration, Research Institute for Nature and Forest (INBO), Brussels, Belgium, 1-4.

Measles, D., and Bugosh, N. (2007). "Making and building a fluvial geomorphic reclamation design at an active draggling mine using the GeoFluv ${ }^{\mathrm{TM}}$ design method." Proc., Joint Conference of the 24th Annual Meetings of the American Society of Mining and Reclamation, ASMR, Lexington, KY, 449-456.

Michael, P., Superfesky, M., and Uranoswki, L. (2010). "Challenges of applying geomorphic and stream reclamation methodologies to mountaintop mining and excess spoil fill construction in steep slope topography (e.g. central Appalachia)." Proc., Joint Conference of the $27^{\text {th }}$ Annual Meetings of the American Society of Mining and Reclamation, $12^{\text {th }}$ Annual Pennsylvania Abandoned Mine Reclamation Conference, and $4^{\text {th }}$ Annual Appalachian Regional Reforestation Initiative Mined Land Reforestation Conference, ASMR, Lexington, KY, 610-634.

Moo-Young, H. K., \& Zimmie, T. F. (1996). "Geotechnical properties of paper mill sludges for use in landfill covers." Journal of Geotechnical Engineering,122(9), 768-775.

National Oceanic and Atmospheric Administration (NOAA). (2015). "Precipitation Frequency Data Server (PFDS)." Hydrometeorological Design Studies Center. $<$ http://hdsc.nws.noaa.gov> (Dec. 4, 2015).

Nicolau, J.M. (2003). "Trends in relief design and construction in opencast mining reclamation." Land Degradation and Development, 14, 215-226. DOI: 10.1002/ldr.548

Quaranta, J. D., \& Tolikonda, R. (2011). "Design of non-woven geotextiles for coal refuse filtration." Geotextiles and Geomembranes, 29(6), 557-566.

Robson, M. Spots, R., Wade, R., and Erickson, W. (2009). "A case history: Limestone quarry reclamation using fluvial geomorphic design techniques." Proc., Joint Conference of the $26^{\text {th }}$ Annual Meetings of the American Society of Mining and Reclamation and $11^{\text {th }}$ Billings Land Reclamation Symposium, ASMR, Lexington, KY, 1166-1175.

Russell, H.B. (2012). "Soil and slope stability study of geomorphic landform profiles versus approximate original contour for valley fill designs." M.S. Thesis, West Virginia University, Morgantown, WV, $238 \mathrm{p}$. 
Russell, H., DePriest, N., and Quaranta, J.D. (2014). "Stability analysis comparison of conventional valley-fill to geomorphic landform designs." Trans., Society of Mining Metallurgy and Exploration, 336, 414-420.

Schor, H.J., and Gray, D.H. (2007). Landforming: an environmental approach to hillside development, mine reclamation and watershed restoration, John Wiley \& Sons, Hoboken, NJ, 368 p.

Sears, A.E., Bise, C.J., Quaranta, J.D., and Hopkinson, L.C. (2014). "Field and modeling study for stream mitigation on surface mine sites in West Virginia." Mining Engineering, 66(5), 48-53.

Torres, G.H. (2011). "Estimating the soil-water characteristic curve using grain-size analysis and plasticity index." M.S. Thesis, Arizona State University, Tempe, AZ

Toy, T.J., and Chuse, W.R. (2005). "Topographical reconstruction: a geomorphic approach.” Ecological Engineering, 24, 29-35.

Ward, Ken Jr. (2001, August 12). “A toxic legacy.” Charleston Gazette-Mail. Retrieved from: http://www.wvgazettemail.com/article/20010812/ARTICLE/308129998/ 


\section{APPENDIX A.SOIL TESTING DATA}

\section{Hydrometer Results}

Table A.1: Shale sample hydrometer data

\begin{tabular}{|c|c|c|c|c|c|c|c|c|}
\hline \multicolumn{2}{|c|}{ Hydrometer No.: } & $\begin{array}{l}\text { Sample } \\
\text { Moist } \\
\text { Mass, g }\end{array}$ & \multicolumn{2}{|c|}{$\begin{array}{l}\text { Moisture Content, } \\
\text { w\% }\end{array}$} & \multicolumn{2}{|c|}{$\begin{array}{l}\text { Sample Dry } \\
\text { Mass, g }\end{array}$} & \multicolumn{2}{|c|}{ Specific Gravity, $\mathrm{G}_{\mathrm{s}}$} \\
\hline $152 \mathrm{H}$ & & 100 & 6.36 & & 93.64 & & 2.19 & \\
\hline $\begin{array}{l}\text { Elapsed } \\
\text { Time, } \\
\text { (T) min }\end{array}$ & $\begin{array}{l}\text { Hydrometer } \\
\text { Reading }\end{array}$ & $\begin{array}{l}\text { Actual } \\
\text { Hydrometer } \\
\text { Reading, R }\end{array}$ & $\begin{array}{l}\text { Temp, } \\
{ }^{\circ} \mathrm{C}\end{array}$ & K (Table3) & $\begin{array}{l}\text { a } \\
\text { (Table1) }\end{array}$ & $\begin{array}{l}\% \\
\text { Finer, } \\
\mathrm{P}\end{array}$ & $\begin{array}{l}\text { Effective } \\
\text { Depth, } \\
\text { (L) cm } \\
\text { (Table } \\
\text { 2) }\end{array}$ & $\begin{array}{l}\text { Particle } \\
\text { Diameter, } \\
\text { (D) mm }\end{array}$ \\
\hline 2 & 65 & 65 & 16 & 0.01249 & 0.98 & 68.0 & 6.5 & 0.0233 \\
\hline 5 & 60 & 60 & 16 & 0.01249 & 0.98 & 62.8 & 6.5 & 0.0148 \\
\hline 15 & 51 & 51 & 16 & 0.01249 & 0.98 & 53.4 & 7.9 & 0.0094 \\
\hline 30 & 46 & 46 & 16 & 0.01249 & 0.98 & 48.1 & 8.8 & 0.0070 \\
\hline 60 & 42 & 42 & 16 & 0.01249 & 0.98 & 44.0 & 9.4 & 0.0051 \\
\hline 250 & 34 & 34 & 18 & 0.01249 & 0.98 & 35.6 & 10.7 & 0.0027 \\
\hline 1440 & 24 & 24 & 20 & 0.01249 & 0.98 & 25.1 & 12.4 & 0.0012 \\
\hline
\end{tabular}

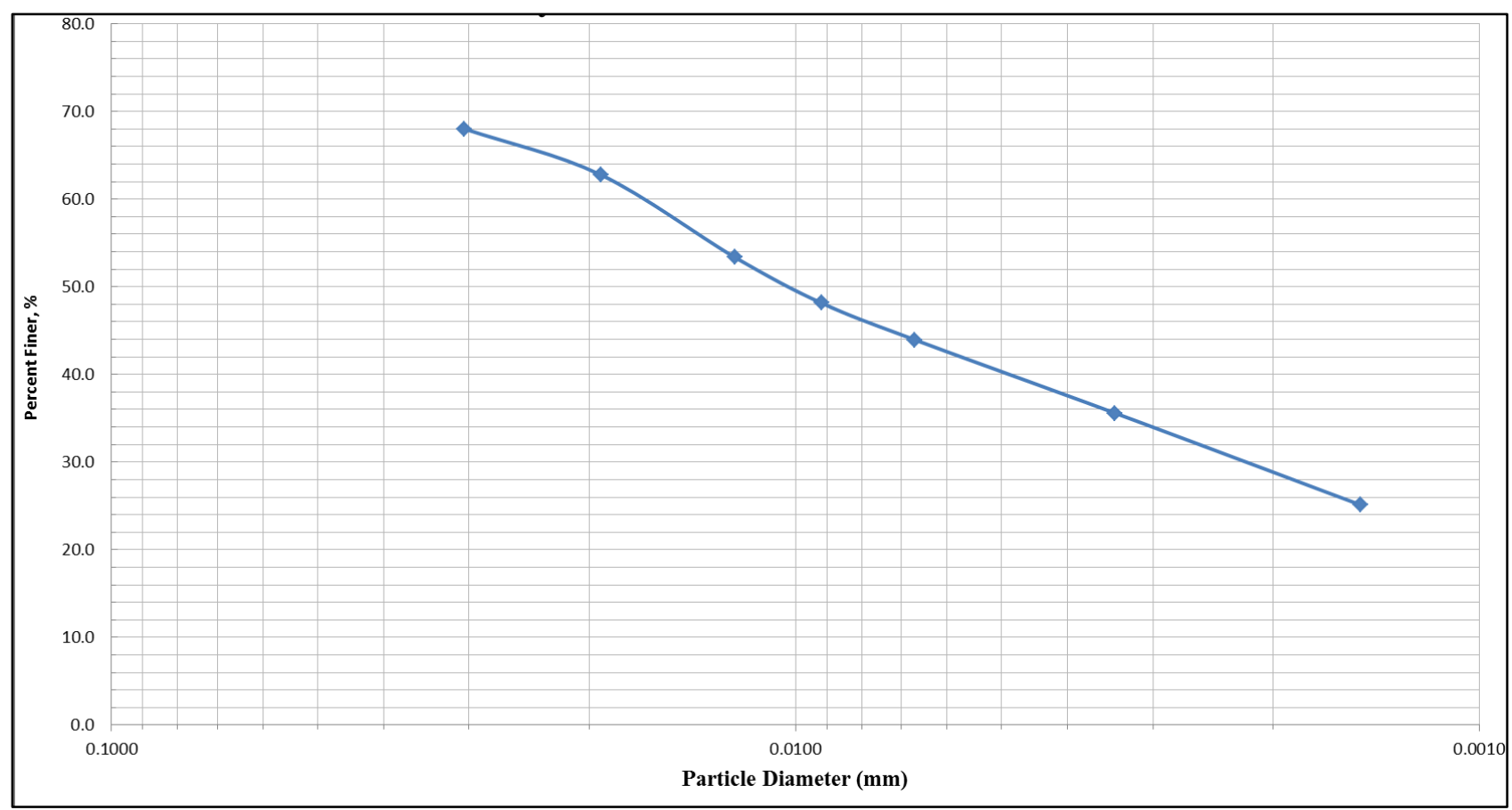

Figure A.1: Particle size curve from Hydrometer for CCR shale

\section{Compaction Results}

Standard Proctor $\left(592 \mathrm{~kJ} / \mathrm{m}^{3}\right)$ 
Table A.2: Compaction Test Results-Standard Proctor Effort

\begin{tabular}{|l|r|r|r|r|}
\hline Test Calculations & \multicolumn{1}{c|}{ Test 1 } & \multicolumn{1}{c|}{ Test 2 } & \multicolumn{1}{l|}{ Test 3 } & \multicolumn{1}{l|}{ Test 4 } \\
\hline Specific Gravity of Soil, $\mathrm{G}_{\mathrm{s}}$ & 2.19 & 2.19 & 2.19 & 2.19 \\
\hline Dry Unit Weight of Compacted Specimen $\left(\mathrm{KN} / \mathrm{m}^{3}\right), \gamma_{\mathrm{d}}$ & 19.75 & 17.31 & 16.30 & 15.57 \\
\hline Dry Unit Weight at $\mathrm{S}=1.0\left(\mathrm{KN} / \mathrm{m}^{3}\right), \gamma_{\mathrm{d}}$ & 19.75 & 17.31 & 16.30 & 15.57 \\
\hline Dry Unit Weight at S=0.9 $\left(\mathrm{KN} / \mathrm{m}^{3}\right), \gamma_{\mathrm{d}}$ & 19.58 & 16.95 & 15.88 & 15.11 \\
\hline Degree of Saturation $(\%), \mathrm{S}=\mathrm{G}_{\mathrm{s}}{ }^{*} \mathrm{w} / \mathrm{e}$ & 0.16 & 0.59 & 0.88 & 0.86 \\
\hline Saturated Water Content, $\mathrm{w}_{\mathrm{sat}}(\%)$ & 23.77 & 18.42 & 16.28 & 20.06 \\
\hline Water Content, $\mathrm{W}=(\mathrm{Mw} / \mathrm{Ms}) \times 100(\%)$ & 3.90 & 10.89 & 14.39 & 17.23 \\
\hline
\end{tabular}

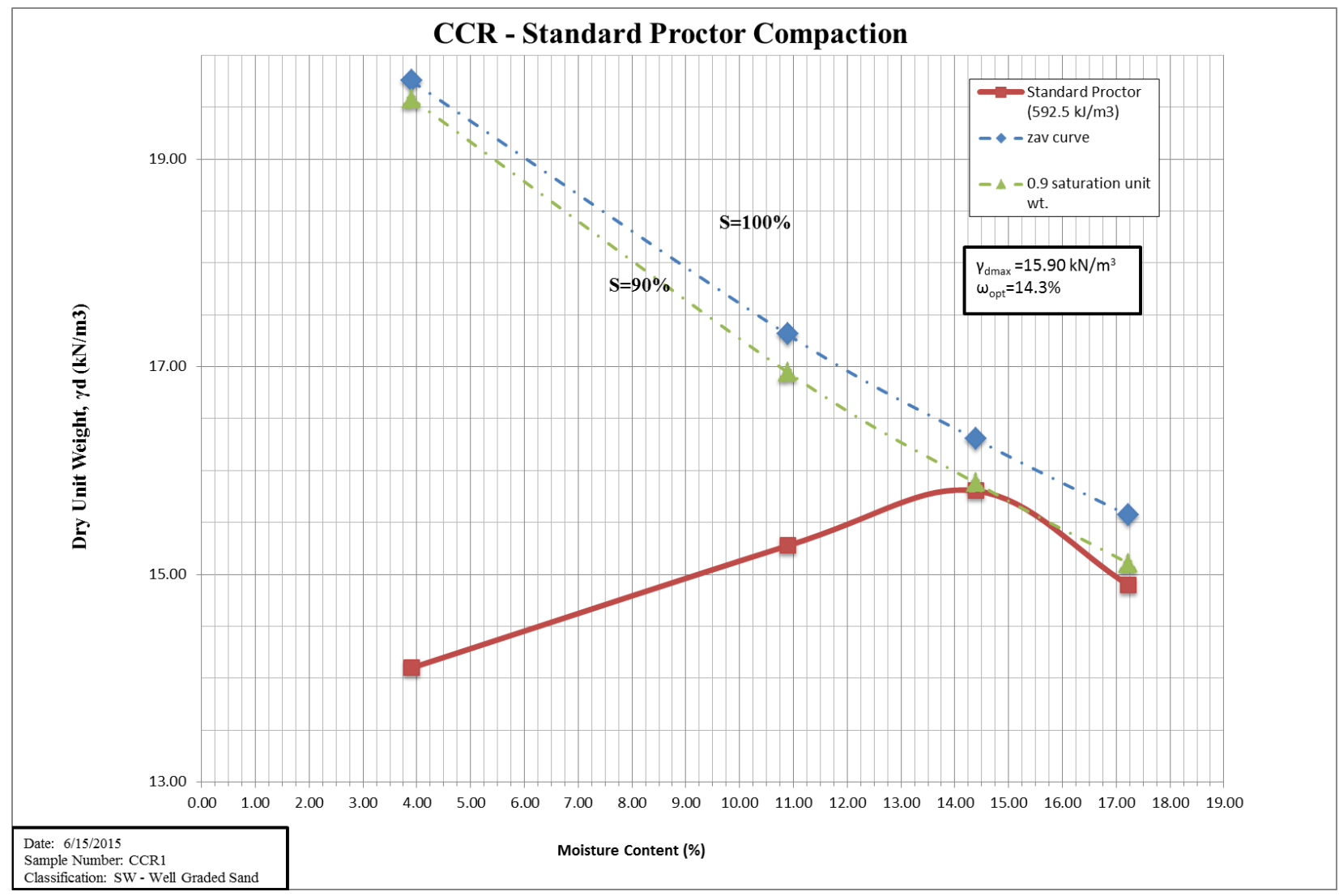

Figure A.2: Standard Proctor Curve with lines at 100\% and 90\% saturation 
34\% Proctor Compaction Energy: 12 blows/layer, 2 layers $\left(203.6 \mathrm{~kJ} / \mathrm{m}^{3}\right)$

Table A.3: Compaction Test Results- 34\% Standard Proctor Effort

\begin{tabular}{|c|c|c|c|c|c|}
\hline Test Calculations & $\begin{array}{c}\text { Test } \\
1\end{array}$ & $\begin{array}{c}\text { Test } \\
2\end{array}$ & $\begin{array}{c}\text { Test } \\
3\end{array}$ & $\begin{array}{c}\text { Test } \\
4\end{array}$ & $\begin{array}{c}\text { Test } \\
5\end{array}$ \\
\hline Specific Gravity of Soil, $\mathrm{G}_{\mathrm{s}}$ & 2.19 & 2.19 & 2.19 & 2.19 & 2.19 \\
\hline $\begin{array}{l}\text { Dry Unit Weight of Compacted Specimen }\left(\mathrm{KN} / \mathrm{m}^{3}\right) \text {, } \\
\gamma_{\mathrm{d}}\end{array}$ & 13.65 & 13.50 & 14.87 & 15.07 & 14.92 \\
\hline Dry Unit Weight at $\mathrm{S}=1.0\left(\mathrm{KN} / \mathrm{m}^{3}\right), \gamma_{\mathrm{d}}$ & 19.61 & 17.41 & 16.12 & 15.60 & 15.26 \\
\hline Dry Unit Weight at $S=0.9\left(\mathrm{KN} / \mathrm{m}^{3}\right), \gamma_{\mathrm{d}}$ & 19.42 & 17.06 & 15.68 & 15.14 & 14.79 \\
\hline Degree of Saturation $(\%), \mathrm{S}=\mathrm{G}_{\mathrm{s}}{ }^{*} \mathrm{w} / \mathrm{e}$ & 0.16 & 0.39 & 0.75 & 0.89 & 0.93 \\
\hline Saturated Water Content, $\mathrm{w}_{\text {sat }}(\%)$ & 26.07 & 26.87 & 20.16 & 19.29 & 19.97 \\
\hline Water Content, $(\%) \mathrm{W}=\left(\mathrm{M}_{\mathrm{w}} / \mathrm{M}_{\mathrm{s}}\right) \times 100$ & 4.26 & 10.56 & 15.09 & 17.09 & 18.48 \\
\hline
\end{tabular}

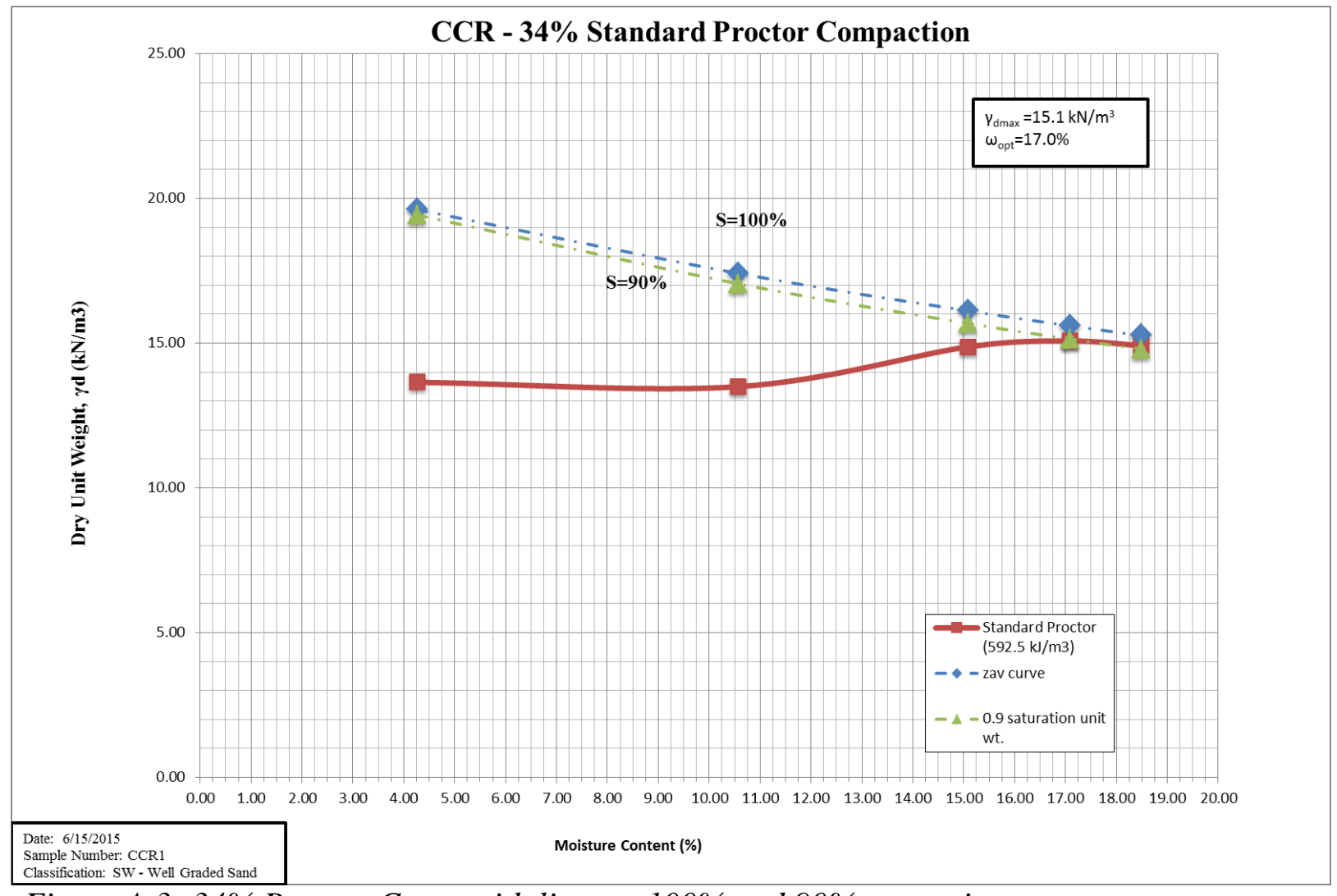

Figure A.3: 34\% Proctor Curve with lines at 100\% and 90\% saturation 
11\% Proctor Compaction Energy: 4 blows/layer, 2 layers $\left(67.85 \mathrm{~kJ} / \mathrm{m}^{3}\right)$

Table A.4: Compaction Test Results: 11\% Standard Proctor Effort

\begin{tabular}{|c|c|c|c|c|c|}
\hline Test Calculations & $\begin{array}{l}\text { Test } \\
1 \\
\end{array}$ & $\begin{array}{l}\text { Test } \\
2\end{array}$ & $\begin{array}{l}\text { Test } \\
3\end{array}$ & $\begin{array}{l}\text { Test } \\
4 \\
\end{array}$ & $\begin{array}{l}\text { Test } \\
5\end{array}$ \\
\hline Specific Gravity of Soil, $\mathrm{G}_{\mathrm{s}}$ & 2.19 & 2.19 & 2.19 & 2.19 & 2.19 \\
\hline $\begin{array}{l}\text { Dry Unit Weight of Compacted Specimen }\left(\mathrm{KN} / \mathrm{m}^{3}\right) \text {, } \\
\gamma_{\mathrm{d}}\end{array}$ & 12.67 & 11.84 & 12.53 & 14.47 & 14.18 \\
\hline Dry Unit Weight at $\mathrm{S}=1.0\left(\mathrm{KN} / \mathrm{m}^{3}\right), \gamma_{\mathrm{d}}$ & 19.67 & 17.50 & 16.32 & 15.61 & 15.08 \\
\hline Dry Unit Weight at $\mathrm{S}=0.9\left(\mathrm{KN} / \mathrm{m}^{3}\right), \gamma_{\mathrm{d}}$ & 19.49 & 17.15 & 15.90 & 15.15 & 14.60 \\
\hline Degree of Saturation $(\%), \mathrm{S}=\mathrm{G}_{\mathrm{s}}{ }^{*} \mathrm{w} / \mathrm{e}$ & 0.13 & 0.28 & 0.44 & 0.78 & 0.82 \\
\hline Saturated Water Content, $\mathrm{w}_{\text {sat }}(\%)$ & 31.63 & 37.02 & 32.45 & 22.00 & 23.40 \\
\hline Water Content, $(\%) \mathrm{W}=\left(\mathrm{M}_{\mathrm{w}} / \mathrm{M}_{\mathrm{s}}\right) \times 100$ & 4.10 & 10.29 & 14.31 & 17.06 & 19.25 \\
\hline
\end{tabular}

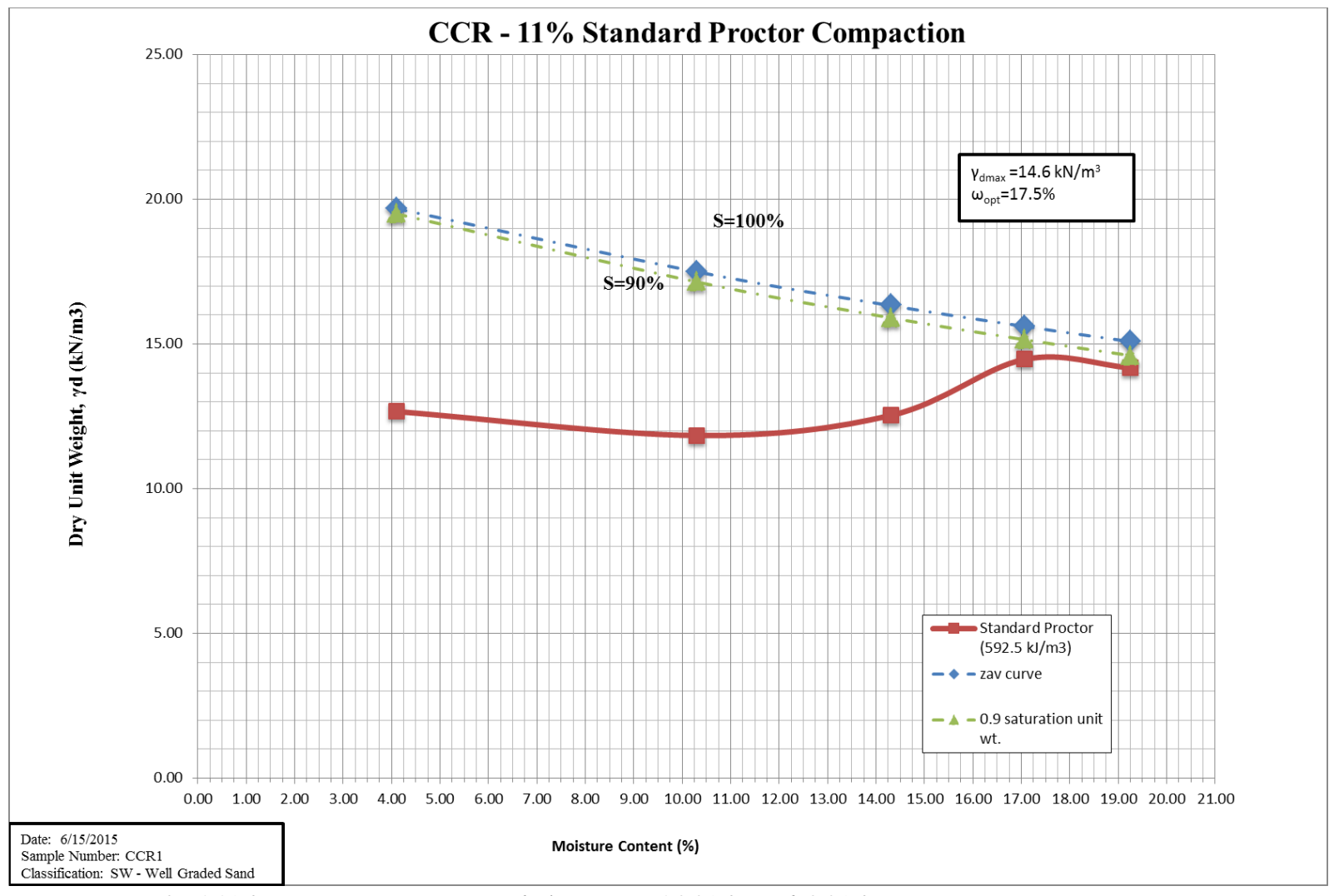

Figure A.4: 11\% Proctor Curve with lines at $100 \%$ and $90 \%$ saturation 
200\% Proctor Compaction Energy: 30 blows/layer, 5 layers $\left(1185 \mathrm{~kJ} / \mathrm{m}^{3}\right.$ )

Table A.5: Compaction Test Results- 200\% Standard Proctor Effort

\begin{tabular}{|c|c|c|c|c|c|}
\hline Test Calculations & $\begin{array}{l}\text { Test } \\
1\end{array}$ & $\begin{array}{l}\text { Test } \\
2\end{array}$ & $\begin{array}{l}\text { Test } \\
3\end{array}$ & \begin{tabular}{|l|} 
Test \\
4
\end{tabular} & $\begin{array}{l}\text { Test } \\
5\end{array}$ \\
\hline Specific Gravity of Soil, $\mathrm{G}_{\mathrm{s}}$ & 2.19 & 2.19 & 2.19 & 2.19 & 2.19 \\
\hline $\begin{array}{l}\text { Dry Unit Weight of Compacted Specimen }\left(\mathrm{KN} / \mathrm{m}^{3}\right) \text {, } \\
\gamma_{\mathrm{d}}\end{array}$ & 14.80 & 15.15 & 16.02 & 15.60 & 15.03 \\
\hline Dry Unit Weight at $S=1.0\left(\mathrm{KN} / \mathrm{m}^{3}\right), \gamma_{\mathrm{d}}$ & 19.46 & 17.94 & 16.88 & 16.08 & 15.58 \\
\hline Dry Unit Weight at $S=0.9\left(\mathrm{KN} / \mathrm{m}^{3}\right), \gamma_{\mathrm{d}}$ & 19.27 & 17.62 & 16.49 & 15.65 & 15.12 \\
\hline Degree of Saturation (\%), $\mathrm{S}=\mathrm{G}_{\mathrm{s}}{ }^{*} \mathrm{w} / \mathrm{e}$ & 0.23 & 0.47 & 0.80 & 0.89 & 0.88 \\
\hline Saturated Water Content, $\mathrm{w}_{\text {sat }}(\%)$ & 20.48 & 18.95 & 15.44 & 17.10 & 19.47 \\
\hline Water Content, $(\%) \mathrm{W}=\left(\mathrm{M}_{\mathrm{w}} / \mathrm{M}_{\mathrm{s}}\right) \times 100$ & 4.64 & 8.90 & 12.33 & 15.21 & 17.17 \\
\hline
\end{tabular}

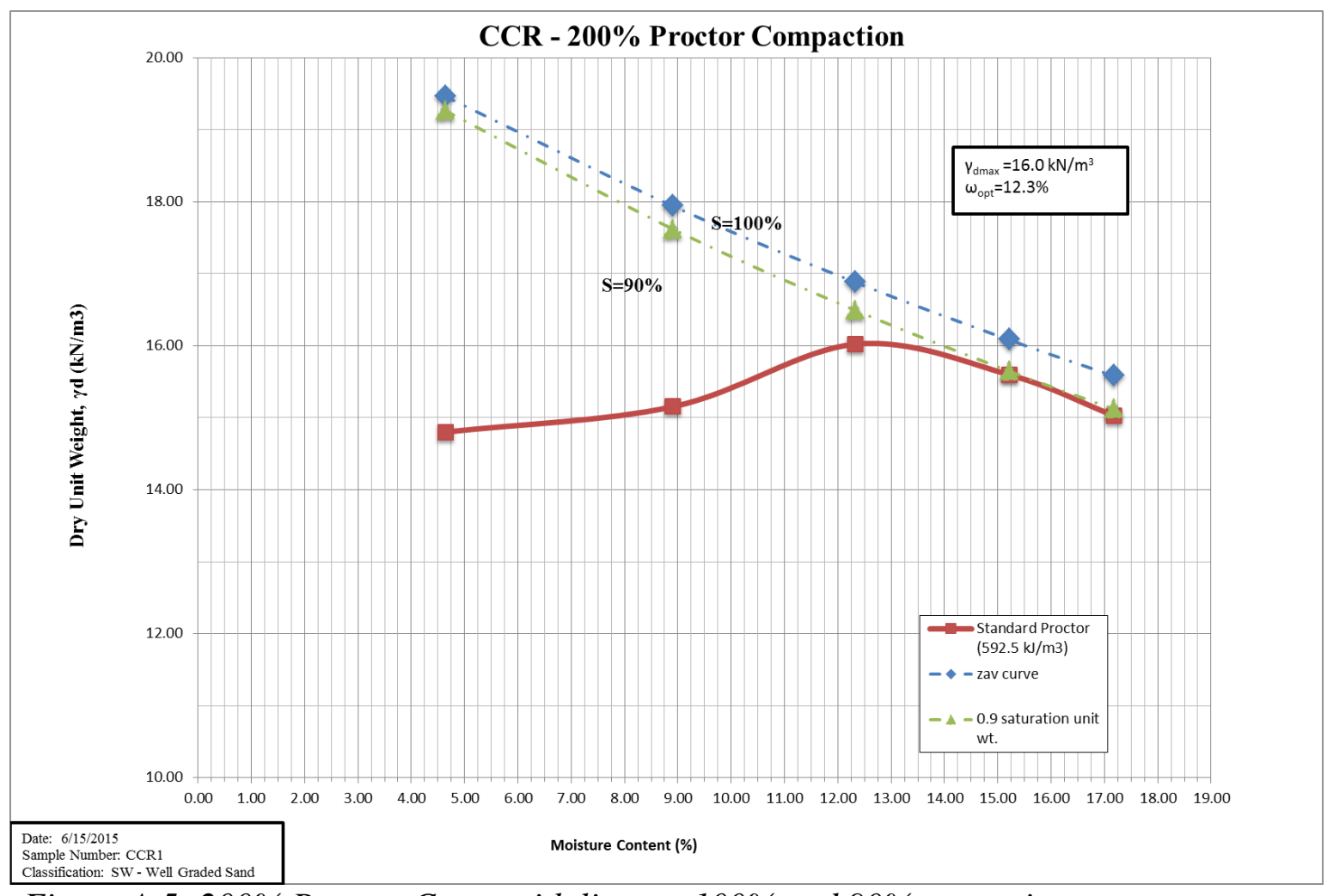

Figure A.5: $200 \%$ Proctor Curve with lines at 100\% and 90\% saturation 
MGro Compaction Data

Table A.6: Compaction test data for MGro ${ }^{\mathrm{TM}}$

\begin{tabular}{|l|l|l|l|l|l|l|l|}
\hline Test Calculations & $\begin{array}{l}\text { Test } \\
\mathbf{1}\end{array}$ & $\begin{array}{l}\text { Test } \\
\mathbf{2}\end{array}$ & $\begin{array}{l}\text { Test } \\
\mathbf{3}\end{array}$ & $\begin{array}{l}\text { Test } \\
\mathbf{4}\end{array}$ & $\begin{array}{l}\text { Test } \\
\mathbf{5}\end{array}$ & $\begin{array}{l}\text { Test } \\
\mathbf{6}\end{array}$ & $\begin{array}{l}\text { Test } \\
\mathbf{7}\end{array}$ \\
\hline Specific Gravity of Soil, $\mathrm{G}_{\mathrm{s}}$ & 2.20 & 2.20 & 2.20 & 2.20 & 2.20 & 2.20 & 2.20 \\
\hline $\begin{array}{l}\text { Dry Unit Weight of Compacted } \\
\text { Specimen }\left(\mathrm{KN} / \mathrm{m}^{3}\right), \gamma_{\mathrm{d}}\end{array}$ & 7.82 & 7.93 & 7.99 & 7.80 & 7.46 & 7.10 & 6.81 \\
\hline Dry Unit Weight at $\mathrm{S}=1.0\left(\mathrm{KN} / \mathrm{m}^{3}\right), \gamma_{\mathrm{d}}$ & 10.66 & 9.38 & 9.03 & 8.76 & 8.09 & 7.65 & 7.20 \\
\hline Dry Unit Weight at $\mathrm{S}=0.9\left(\mathrm{KN} / \mathrm{m}^{3}\right), \gamma_{\mathrm{d}}$ & 10.09 & 8.83 & 8.49 & 8.22 & 7.57 & 7.14 & 6.71 \\
\hline Degree of Saturation $(\%), \mathrm{S}=\mathrm{G}_{\mathrm{s}}{ }^{*} \mathrm{w} / \mathrm{e}$ & $58 \%$ & $76 \%$ & $82 \%$ & $83 \%$ & $88 \%$ & $89 \%$ & $92 \%$ \\
\hline Saturated Water Content, $\mathrm{w}_{\mathrm{sat}}(\%)$ & 79.78 & 77.93 & 77.03 & 80.10 & 85.73 & 92.38 & 98.20 \\
\hline Water Content, $\mathrm{W}=(\mathrm{Mw} / \mathrm{Ms}) \times 100(\%)$ & 46.41 & 58.86 & 62.91 & 66.26 & 75.56 & 82.58 & 90.44 \\
\hline
\end{tabular}


60/40 Shale blend

Table A.7: Sample test data for 60/40 blend standard proctor compaction

\begin{tabular}{|l|r|r|r|r|}
\hline Test Calculations & \multicolumn{1}{|c|}{ Test 1 } & \multicolumn{1}{c|}{ Test 2 } & \multicolumn{1}{c|}{ Test 3 } & \multicolumn{1}{c|}{ Test 4 } \\
\hline Specific Gravity of Soil, $\mathrm{G}_{\mathrm{s}}$ & 2.00 & 2.00 & 2.00 & 2.00 \\
\hline Dry Unit Weight of Compacted Specimen $\left(\mathrm{KN} / \mathrm{m}^{3}\right), \gamma_{\mathrm{d}}$ & 11.04 & 11.62 & 10.63 & 10.49 \\
\hline Dry Unit Weight at $\mathrm{S}=1.0\left(\mathrm{KN} / \mathrm{m}^{3}\right), \gamma_{\mathrm{d}}$ & 14.72 & 12.43 & 11.41 & 11.18 \\
\hline Dry Unit Weight at $\mathrm{S}=0.9\left(\mathrm{KN} / \mathrm{m}^{3}\right), \gamma_{\mathrm{d}}$ & 14.32 & 11.95 & 10.91 & 10.67 \\
\hline Degree of Saturation $(\%), \mathrm{S}=\mathrm{G}_{\mathrm{s}}{ }^{*} \mathrm{w} / \mathrm{e}$ & 0.43 & 0.84 & 0.85 & 0.87 \\
\hline Saturated Water Content, $\mathrm{w}_{\mathrm{sat}}(\%)$ & 38.66 & 34.22 & 42.07 & 43.35 \\
\hline Water Content, $\mathrm{W}=(\mathrm{Mw} / \mathrm{Ms}) \times 100(\%)$ & 16.51 & 28.73 & 35.79 & 37.59 \\
\hline
\end{tabular}

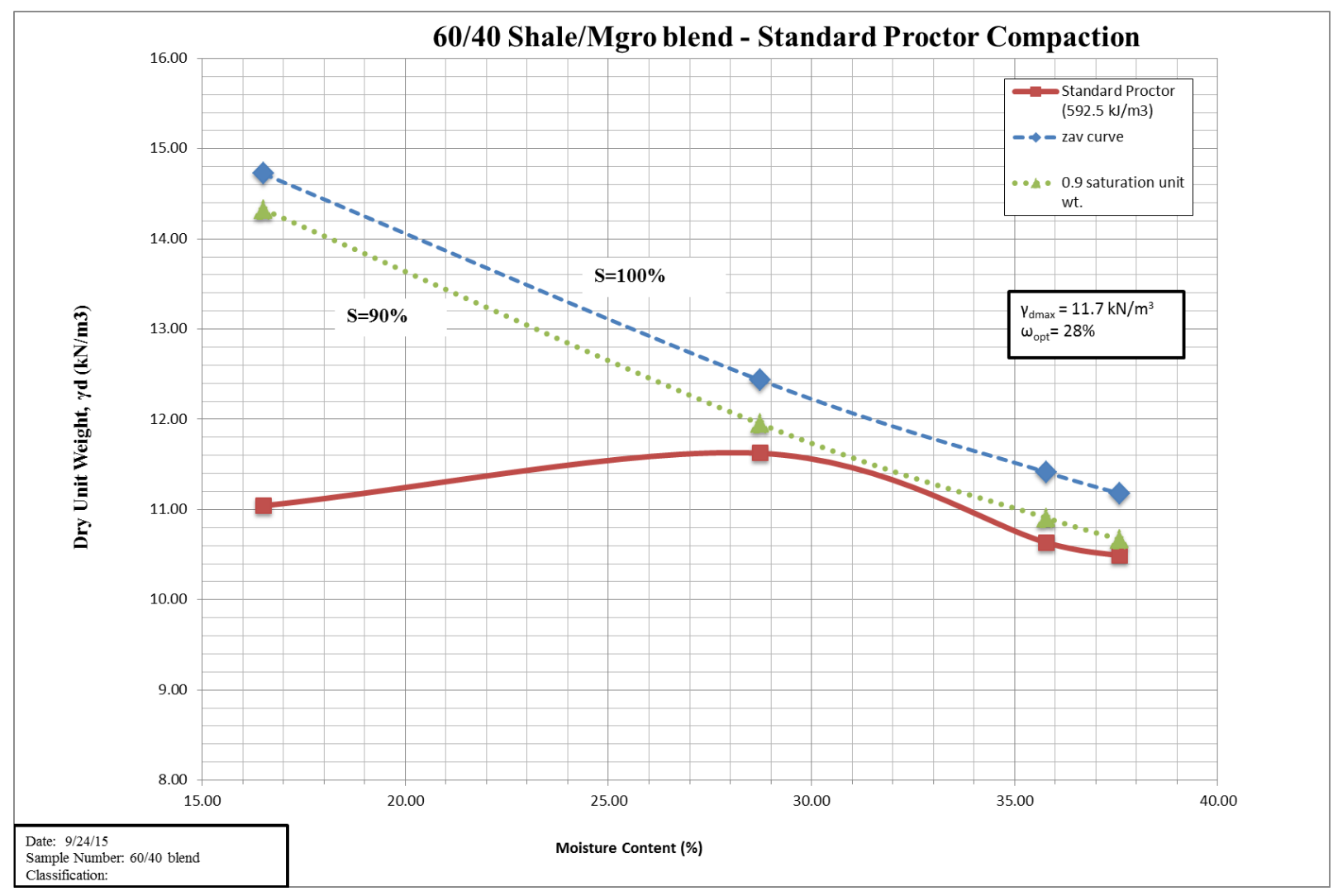

Figure A.6: Compaction Curve for 60/40 blend at standard proctor effort (592.5 kJ/m3) 
$80 / 20$ blend

Table A.8: Test data for 80/20 blend standard proctor compaction

\begin{tabular}{|l|r|r|r|}
\hline Test Calculations & \multicolumn{1}{|c|}{ Test 1 } & \multicolumn{1}{|c|}{ Test 2 } & Test 3 \\
\hline Specific Gravity of Soil, $\mathrm{G}_{\mathrm{s}}$ & 1.97 & 1.97 & 1.97 \\
\hline Dry Unit Weight of Compacted Specimen $\left(\mathrm{KN} / \mathrm{m}^{3}\right), \gamma_{\mathrm{d}}$ & 12.18 & 12.98 & 12.00 \\
\hline Dry Unit Weight at $\mathrm{S}=1.0\left(\mathrm{KN} / \mathrm{m}^{3}\right), \gamma_{\mathrm{d}}$ & 15.35 & 13.96 & 12.68 \\
\hline Dry Unit Weight at $\mathrm{S}=0.9\left(\mathrm{KN} / \mathrm{m}^{3}\right), \gamma_{\mathrm{d}}$ & 15.01 & 13.54 & 12.21 \\
\hline Degree of Saturation $(\%), \mathrm{S}=\mathrm{G}_{\mathrm{s}}{ }^{*} \mathrm{w} / \mathrm{e}$ & 0.44 & 0.79 & 0.86 \\
\hline Saturated Water Content, $\mathrm{w}_{\mathrm{sat}}(\%)$ & 29.64 & 24.67 & 30.85 \\
\hline Water Content, w=(Mw/Ms)x100 $(\%)$ & 13.03 & 19.38 & 26.47 \\
\hline
\end{tabular}

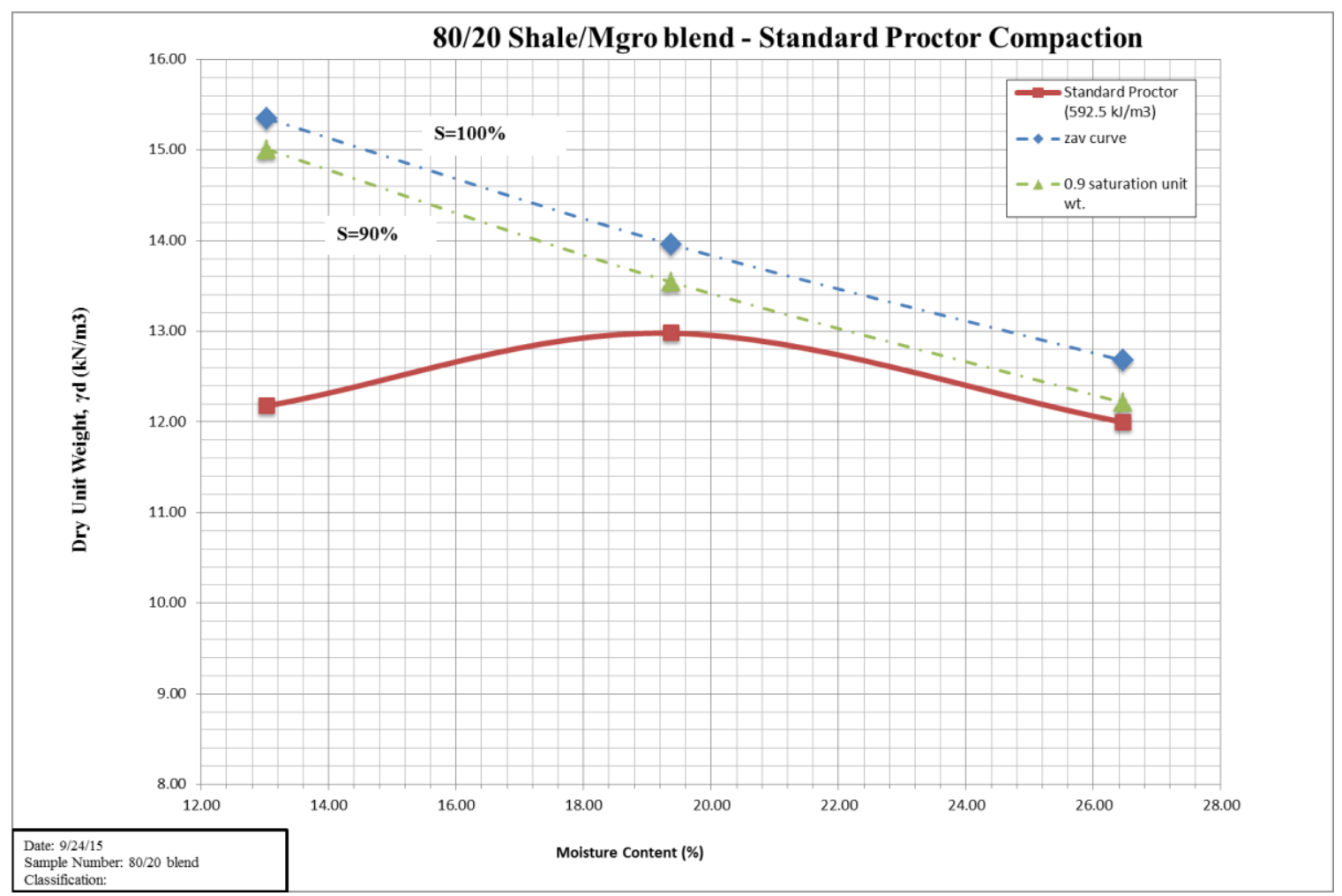

Figure A.7: Compaction curve for 80/20 blend standard proctor tests 


\section{Direct Shear Testing Results}

\section{Standard Proctor Specimens}

Table A.9: Compiled direct shear testing results for specimens compacted to Standard Proctor $\left(592.5 \mathrm{~kJ} / \mathrm{m}^{3}\right)$

\begin{tabular}{|c|c|c|c|}
\hline \multicolumn{4}{|c|}{ Max Shear Stress vs. Normal Stress } \\
\hline Date & Sample & Compaction & Material \\
\hline $7 / 14 / 2015$ & CCRStd Compiled & 25 Blows/Layer, 3 Layers $\left(592.5 \mathrm{~kJ} / \mathrm{m}^{3}\right)$ & Passing No. 4 \\
\hline Specimen Number & Max Shear Stress (ksf) & Max Shear Stress(psf) & Normal Stress (psf) \\
\hline Deep1 & 12.563 & 12563 & 12000 \\
\hline Deep2 & 11.296 & 11296 & 12000 \\
\hline Deep3 & 11.180 & 11180 & 12000 \\
\hline Med1 & 6.682 & 6682 & 8000 \\
\hline Med2 & 6.365 & 6365 & 8000 \\
\hline Med3 & 6.528 & 6528 & 8000 \\
\hline Low1 & 3.845 & 3845 & 3000 \\
\hline Low2 & 3.631 & 3631 & 3000 \\
\hline Low3 & 3.764 & 3764 & 3000 \\
\hline UL1 & 0.909 & 909 & 500 \\
\hline UL2 & 0.841 & 841 & 500 \\
\hline UL4 & 0.949 & 949 & 500 \\
\hline INTERCEPT & 0 & 0 & 0 \\
\hline Specimen Number & Max Shear Stress(kPa) & Normal Stress (kPa) & \\
\hline Deep1 & 601.59 & 575 & \\
\hline Deep2 & 540.93 & 575 & \\
\hline Deep3 & 535.38 & 575 & \\
\hline Med1 & 320.00 & 383 & \\
\hline Med2 & 304.80 & 383 & \\
\hline Med3 & 312.61 & 383 & \\
\hline Low1 & 184.14 & 144 & \\
\hline Low2 & 173.89 & 144 & \\
\hline Low3 & 180.24 & 144 & \\
\hline UL1 & 43.52 & 24 & \\
\hline UL2 & 40.28 & 24 & \\
\hline UL4 & 45.44 & 24 & \\
\hline INTERCEPT & 0 & 0 & \\
\hline $\mathrm{m}=$ & 0.8815 & $\mathrm{~m}=$ & 0.9394 \\
\hline$\phi_{\text {best fit }}{ }^{\prime}($ degrees $)=$ & 41.397 & $\phi_{\mathrm{c}^{\prime}=0}($ degrees $)=$ & 43.210 \\
\hline $\mathrm{c}^{\prime}(\mathrm{ksf})=$ & 0.535 & $c^{\prime}(\mathrm{kPa})=$ & 0.0 \\
\hline$c^{\prime}(\mathrm{kPa})=$ & 25.597 & & \\
\hline
\end{tabular}




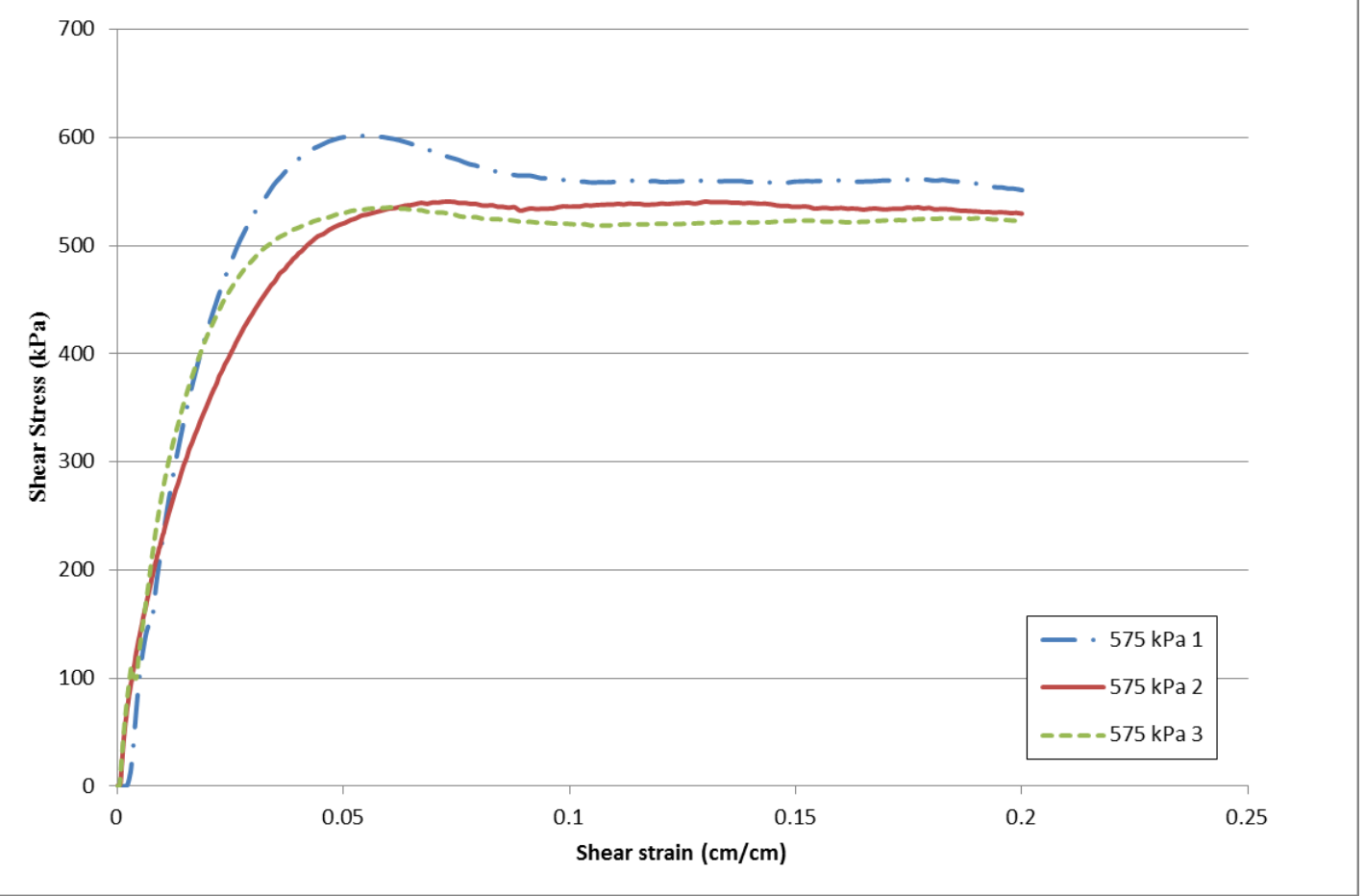

Figure A.8: Shear stress vs. shear strain plot for shale standard compacted direct shear specimens under deep loading condition

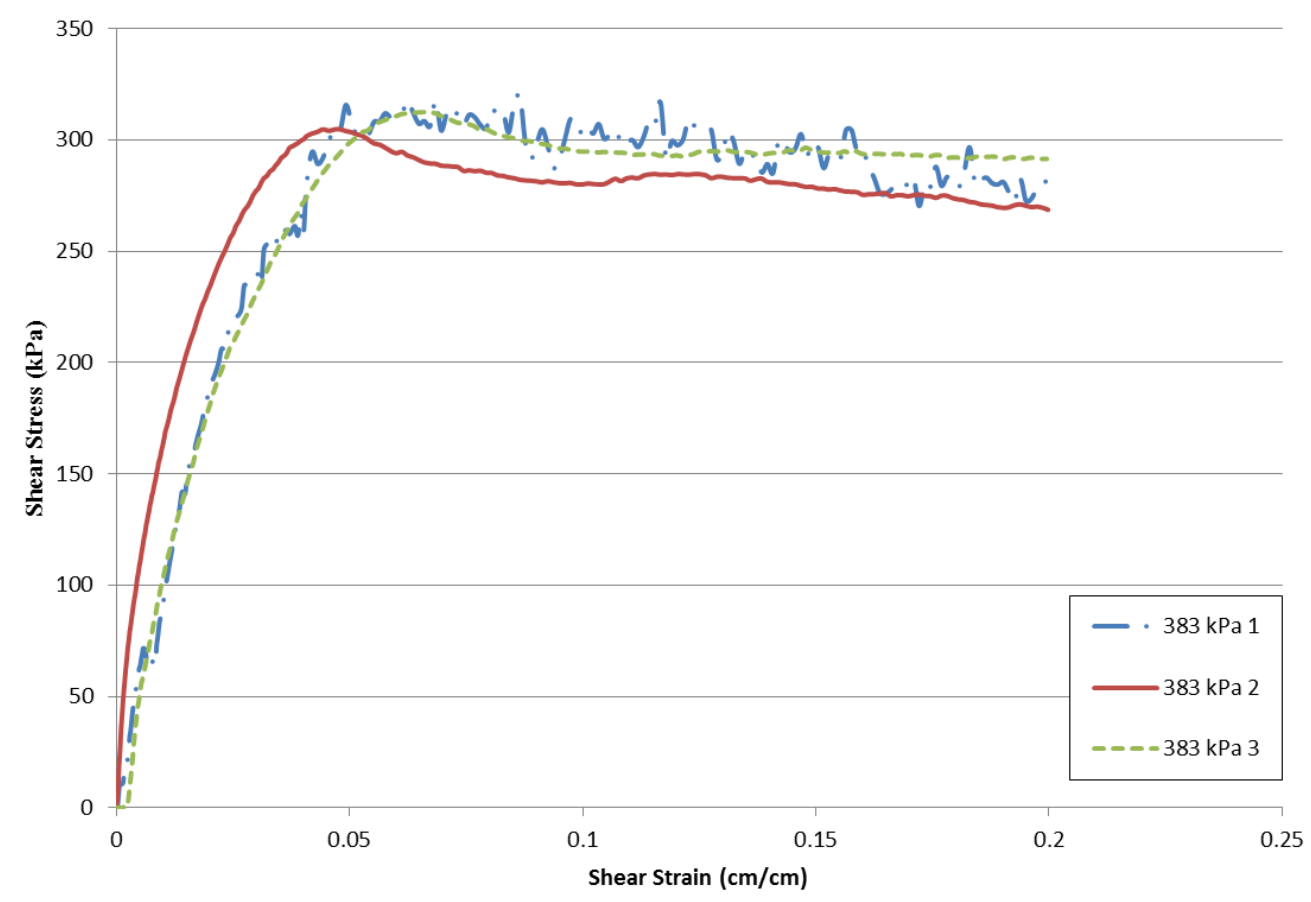

Figure A.9: Shear stress vs. shear strain for shale standard proctor compacted direct shear specimens under medium loading condition 


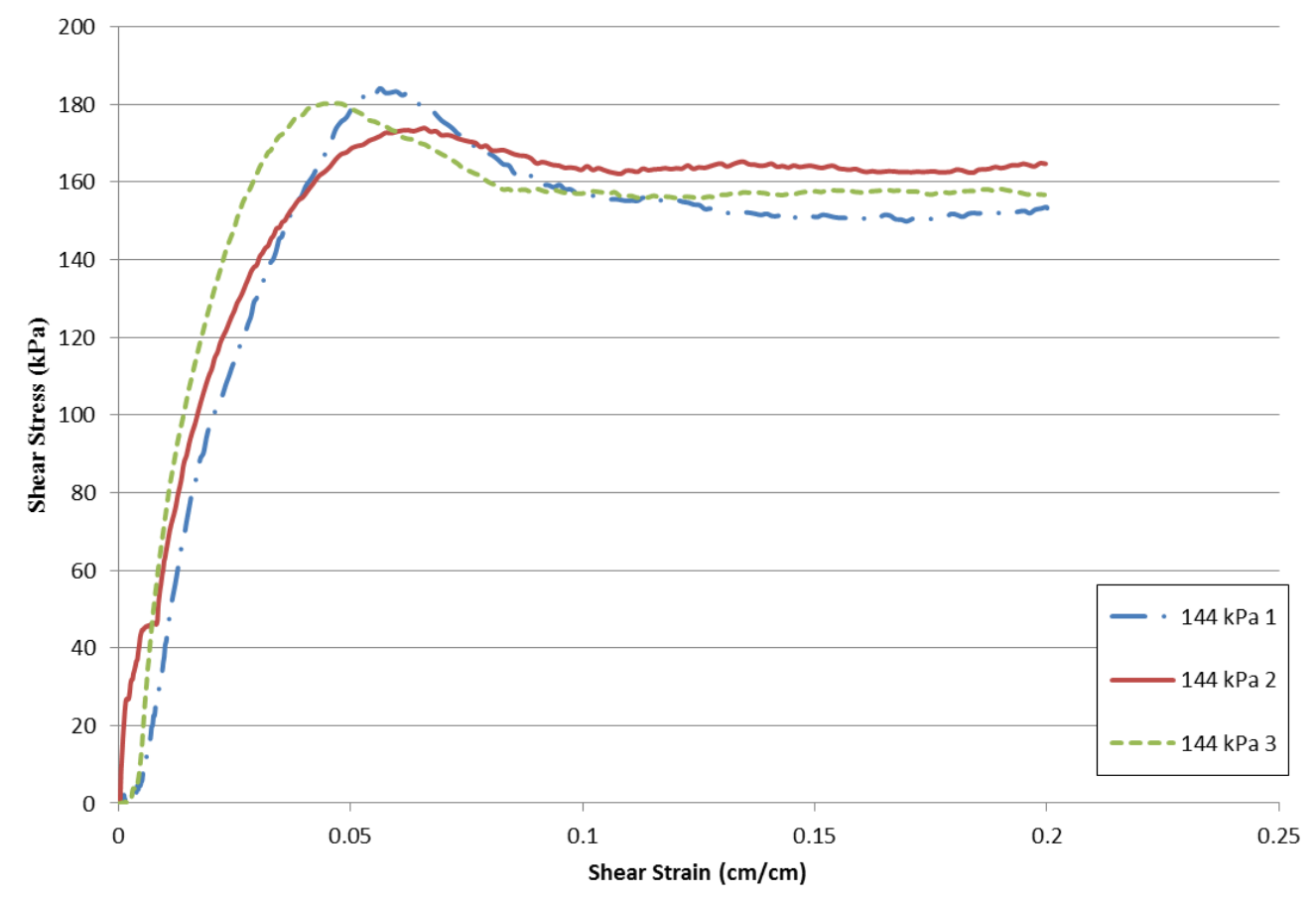

Figure A.10: Shear stress vs. shear strain plot for shale standard proctor compacted direct specimens under low loading condition

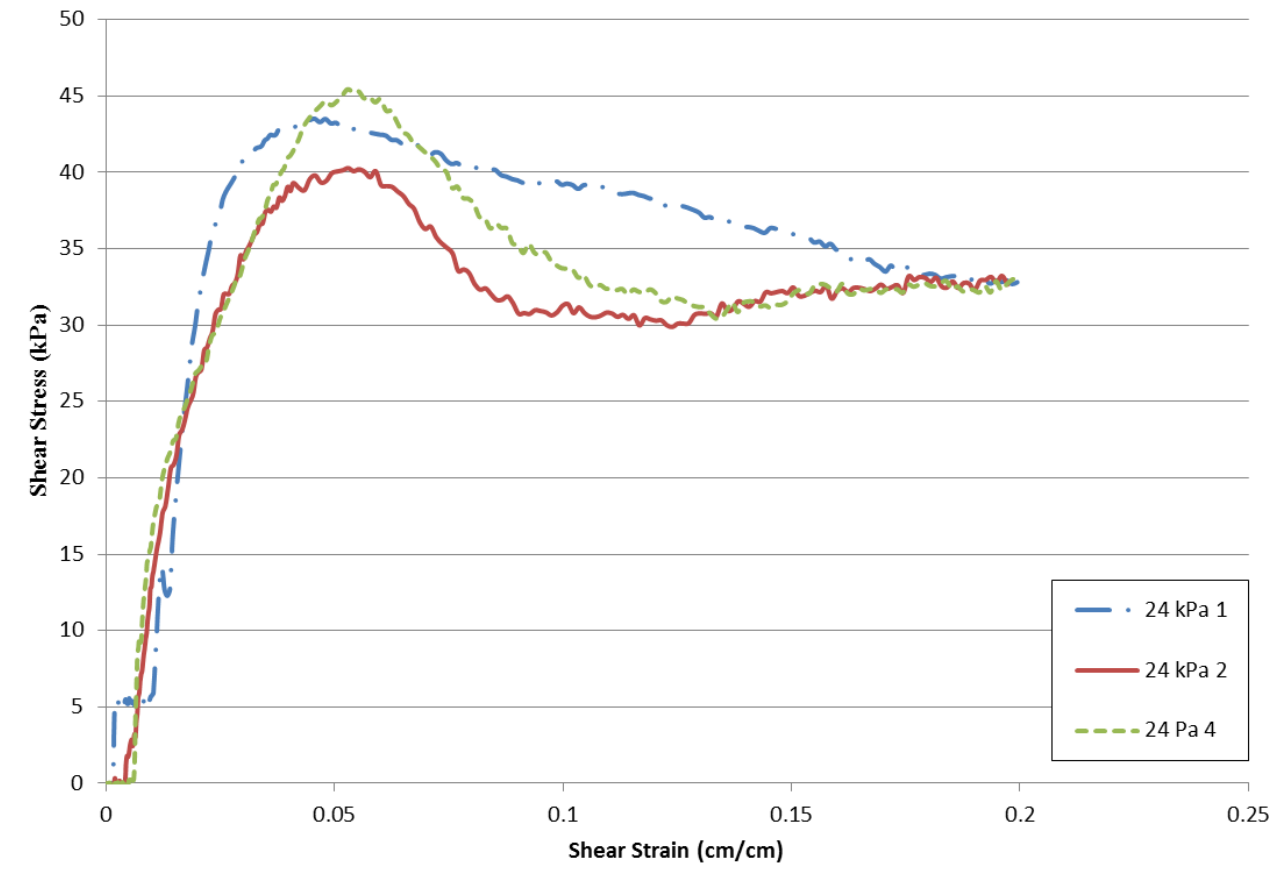

Figure A.11: Shear stress vs. shear strain plot for CCR standard compacted direct shear specimens under surface loading 


\section{4\% Proctor Specimens}

Table A.10: Compiled direct shear testing results for all specimens compacted to $34 \%$ of standard proctor effort

\begin{tabular}{|c|c|c|c|}
\hline \multicolumn{4}{|c|}{ Max Shear Stress vs. Normal Stress } \\
\hline Date & Sample & Compaction & Material \\
\hline $7 / 22 / 2015$ & CCR $34 \%$ & 12 Blows/Layer, 2 Layers $\left(203.6 \mathrm{~kJ} / \mathrm{m}^{3}\right)$ & Passing No. 4 \\
\hline Specimen Number & Max Shear Stress (ksf) & Max Shear Stress(psf) & Normal Stress (psf) \\
\hline Deep 1 & 12.478 & 12478 & 12000 \\
\hline Deep 2 & 11.600 & 11600 & 12000 \\
\hline Deep 3 & 11.452 & 11452 & 12000 \\
\hline Deep 4 & 11.839 & 11839 & 12000 \\
\hline Med 1 & 6.366 & 6366 & 8000 \\
\hline Med 2 & 6.710 & 6710 & 8000 \\
\hline Med 4 & 8.433 & 8433 & 8000 \\
\hline Med 5 & 6.651 & 6651 & 8000 \\
\hline Low 1 & 3.310 & 3310 & 3000 \\
\hline Low 2 & 2.542 & 2542 & 3000 \\
\hline Low 4 & 4.545 & 4545 & 3000 \\
\hline Low 5 & 3.757 & 3757 & 3000 \\
\hline UL 1 & 0.905 & 905 & 500 \\
\hline UL 3 & 0.747 & 747 & 503 \\
\hline UL 5 & 0.988 & 988 & 500 \\
\hline UL 6 & 0.702 & 702 & 500 \\
\hline Intercept & 0 & 0 & 0 \\
\hline Specimen Number & Max Shear Stress(kPa) & Normal Stress (kPa) & \\
\hline Deep 1 & 597.55 & 575 & \\
\hline Deep 2 & 555.48 & 575 & \\
\hline Deep 3 & 548.42 & 575 & \\
\hline Deep 4 & 566.91 & 575 & \\
\hline Med 1 & 304.87 & 383 & \\
\hline Med 2 & 321.33 & 383 & \\
\hline Med 4 & 403.82 & 383 & \\
\hline Med 5 & 318.48 & 383 & \\
\hline Low 1 & 158.49 & 144 & \\
\hline Low 2 & 121.72 & 144 & \\
\hline Low 4 & 217.65 & 144 & \\
\hline Low 5 & 179.93 & 144 & \\
\hline UL 1 & 43.31 & 24 & \\
\hline UL 3 & 47.31 & 24 & \\
\hline UL 5 & 47.31 & 24 & \\
\hline UL 6 & 33.61 & 24 & \\
\hline Intercept & 0 & 0 & \\
\hline $\mathrm{m}=$ & 0.91576679 & $\mathrm{~m}=$ & 0.9644 \\
\hline$\phi_{\text {best fit }}{ }^{\prime}($ degrees $)=$ & 42.482 & $\phi_{c^{\prime}=0}($ degrees $)=$ & 43.962 \\
\hline $\mathrm{c}^{\prime}(\mathrm{ksf})=$ & 0.450 & $c^{\prime}(\mathrm{kPa})=$ & 0.0 \\
\hline$c^{\prime}(\mathrm{kPa})=$ & 21.535 & & \\
\hline
\end{tabular}




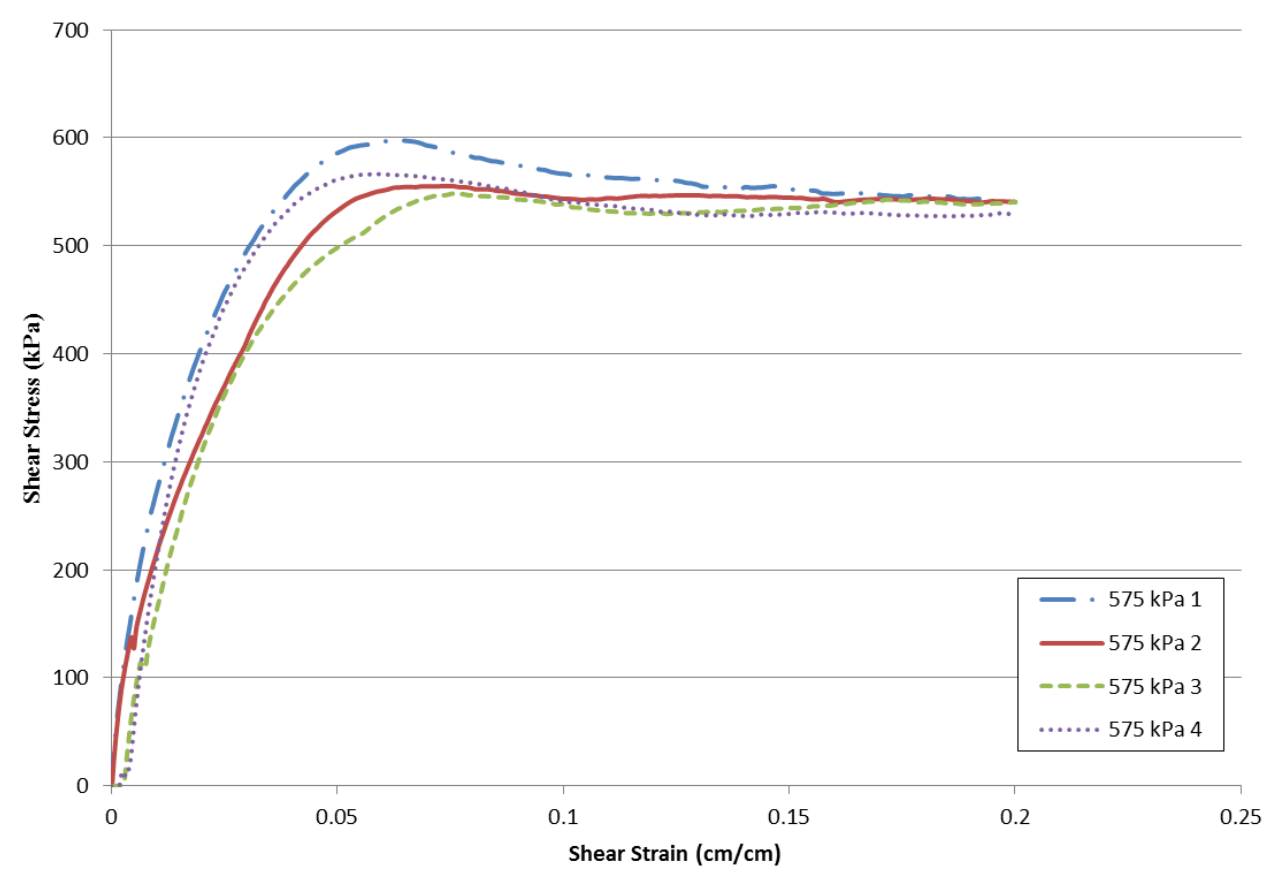

Figure A.12: Shear Stress vs. shear strain plot for shale direct shear specimens compacted to $34 \%$ of standard proctor energy under deep loading condition.

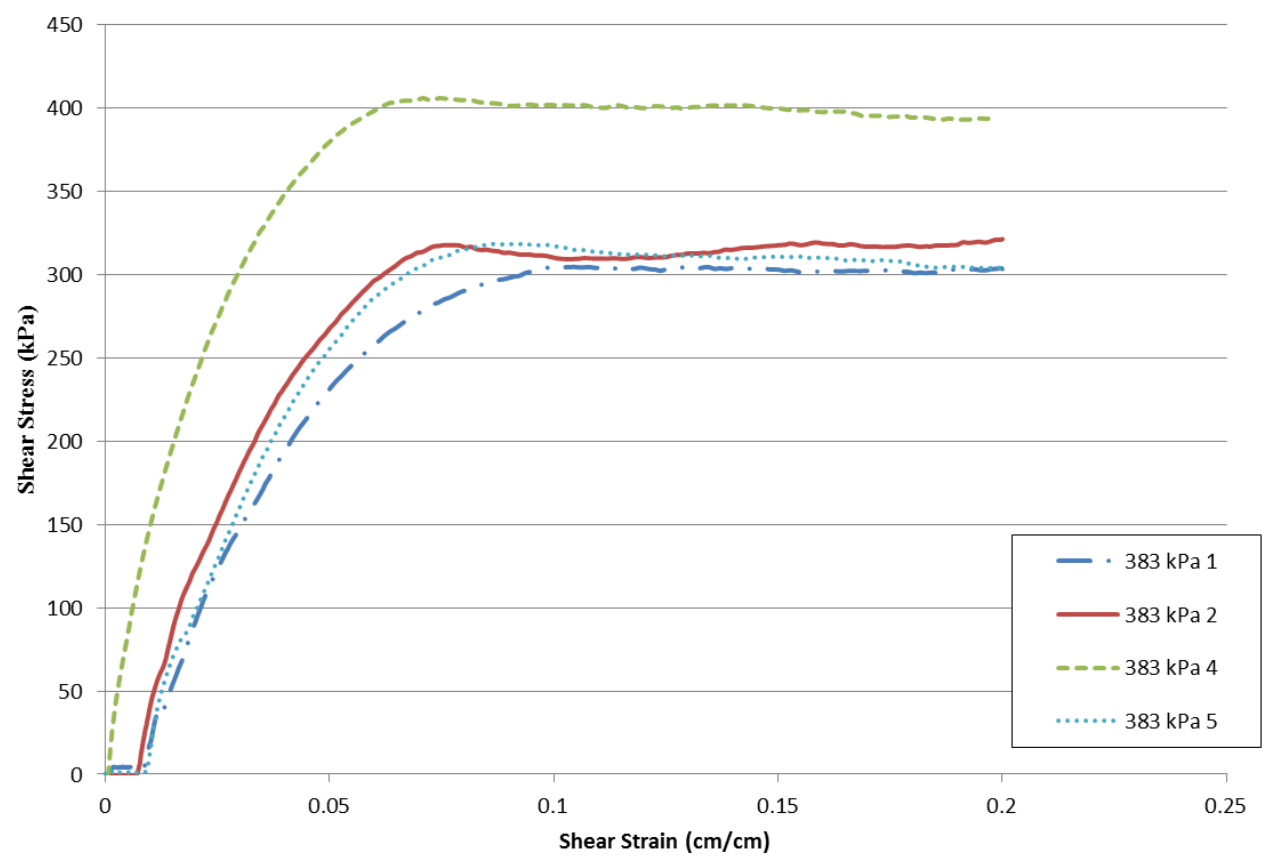

Figure A.13: Shear Stress vs. shear strain plot for shale direct shear specimens compacted to $34 \%$ of standard proctor energy under medium loading condition. 


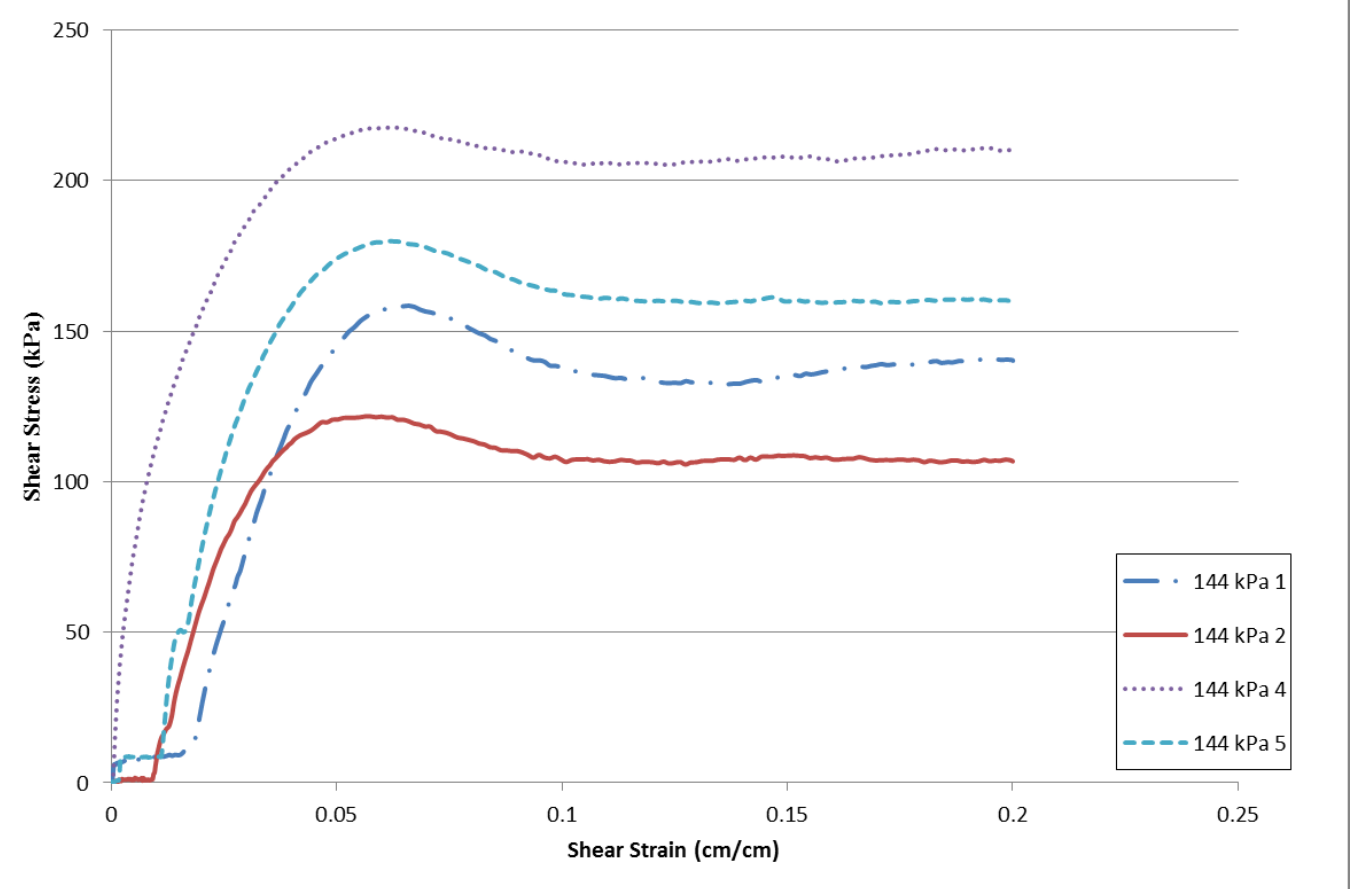

Figure A.14: Shear Stress vs. shear strain plot for shale direct shear specimens compacted to $34 \%$ of standard proctor energy under low (one bench) loading condition.

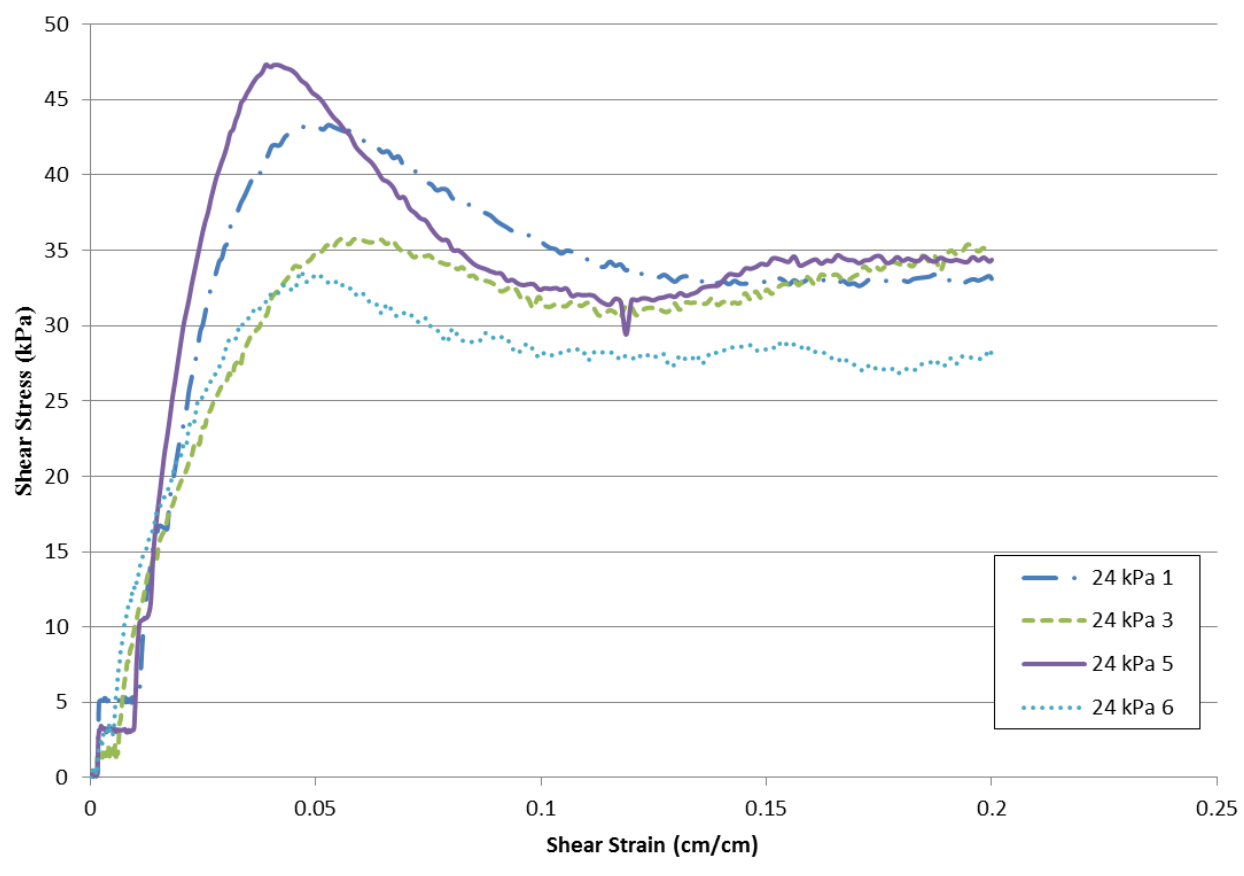

Figure A.15: Shear Stress vs. shear strain plot for shale direct shear specimens compacted to $34 \%$ of standard proctor energy under shallow (surface) loading condition. 


\section{$11 \%$ Proctor Specimens}

Table A.11: Compiled direct shear testing results for all specimens compacted to $67.85 \mathrm{~kJ} / \mathrm{m}^{3}$

\begin{tabular}{|c|c|c|c|}
\hline \multicolumn{4}{|c|}{ Max Shear Stress vs. Normal Stress } \\
\hline Date & Sample & Compaction & Material \\
\hline $7 / 24 / 2015$ & Shale $11 \%$ compacted & 4 Blows/Layer, 2 Layers $\left(67.85 \mathrm{~kJ} / \mathrm{m}^{3}\right)$ & Passing No. 4 \\
\hline Specimen Number & Max Shear Stress (ksf) & Max Shear Stress(psf) & Normal Stress (psf) \\
\hline Deep 1 & 11.673 & 11673 & 12000 \\
\hline Deep 2 & 12.534 & 12534 & 12000 \\
\hline Deep 3 & 11.487 & 11487 & 12000 \\
\hline Deep 4 & 12.448 & 12448 & 12000 \\
\hline Med 1 & 8.145 & 8145 & 8000 \\
\hline Med 2 & 6.416 & 6416 & 8000 \\
\hline Med 3 & 8.579 & 8579 & 8000 \\
\hline Med 4 & 8.049 & 8049 & 8000 \\
\hline Low 1 & 3.330 & 3330 & 3000 \\
\hline Low 3 & 3.196 & 3196 & 3000 \\
\hline Low 4 & 3.223 & 3223 & 3000 \\
\hline Low 5 & 3.059 & 3059 & 3000 \\
\hline UL 1 & 1.134 & 1134 & 500 \\
\hline UL 2 & 0.802 & 802 & 500 \\
\hline UL 3 & 0.926 & 926 & 500 \\
\hline UL 4 & 1.028 & 1028 & 500 \\
\hline UL 5 & 0.717 & 717 & 500 \\
\hline 4 & 0.000 & 0 & 0 \\
\hline Specimen Number & Max Shear Stress(kPa) & Normal Stress (kPa) & \\
\hline Deep 1 & 559.00 & 575 & \\
\hline Deep 2 & 600.20 & 575 & \\
\hline Deep 3 & 550.07 & 575 & \\
\hline Deep 4 & 596.09 & 575 & \\
\hline Med 1 & 390.04 & 383 & \\
\hline Med 2 & 307.26 & 383 & \\
\hline Med 3 & 410.82 & 383 & \\
\hline Med 4 & 385.44 & 383 & \\
\hline Low 1 & 159.47 & 144 & \\
\hline Low 3 & 153.03 & 144 & \\
\hline Low 4 & 154.33 & 144 & \\
\hline Low 5 & 146.50 & 144 & \\
\hline UL 1 & 54.30 & 24 & \\
\hline UL 2 & 38.38 & 24 & \\
\hline UL 3 & 44.33 & 24 & \\
\hline UL 4 & 49.21 & 24 & \\
\hline UL 5 & 34.31 & 24 & \\
\hline 4 & 0 & 0 & \\
\hline $\mathrm{m}=$ & 0.9601 & $\mathrm{~m}=$ & 0.9986 \\
\hline$\phi_{\text {best fit }}{ }^{\prime}($ degrees $)=$ & 43.833 & $\phi_{c^{\prime}=0}($ degrees $)=$ & 44.960 \\
\hline$c^{\prime}(\mathrm{ksf})=$ & 0.355 & $c^{\prime}(\mathrm{kPa})=$ & 0.0 \\
\hline$c^{\prime}(\mathrm{kPa})=$ & 16.990 & & \\
\hline
\end{tabular}




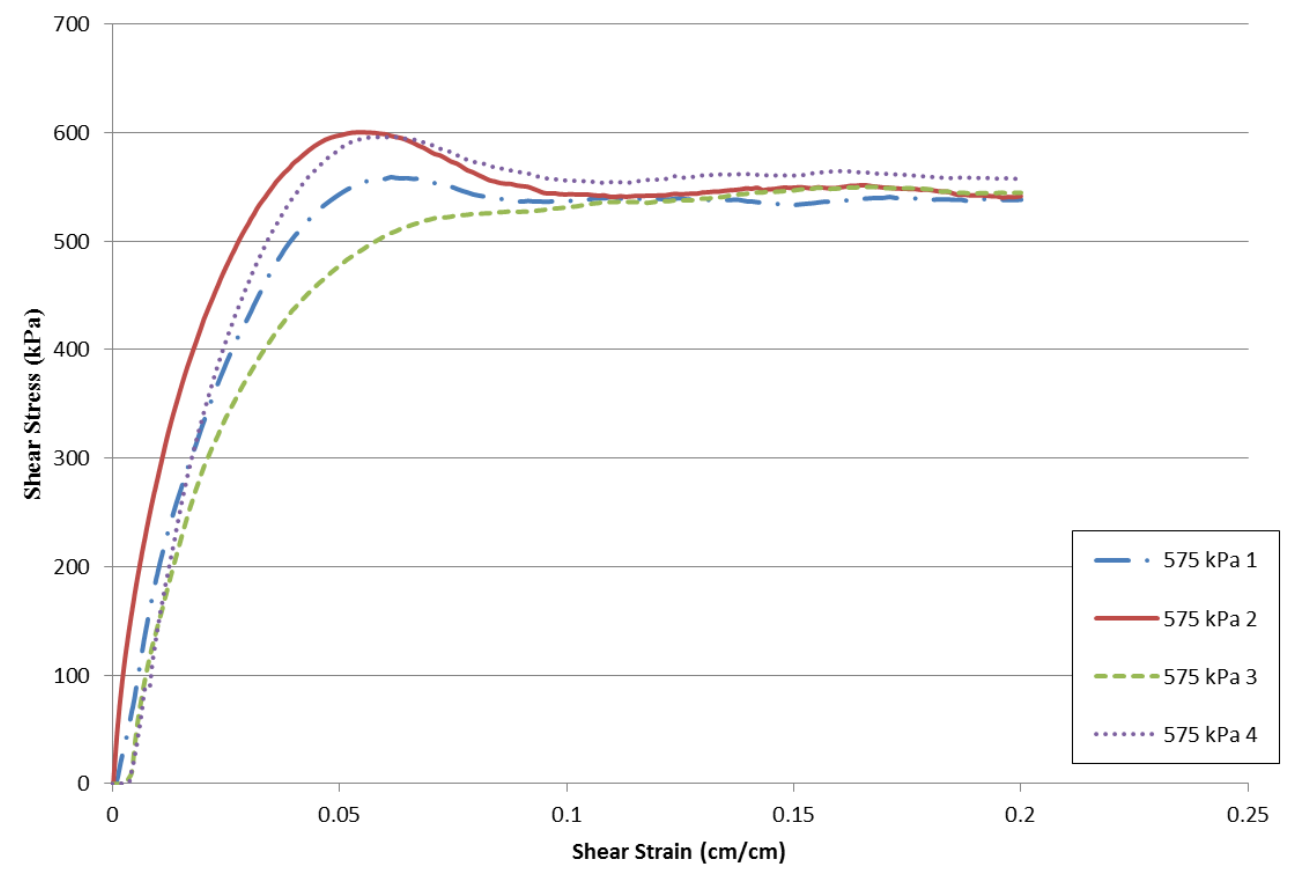

Figure A.16: Shear Stress vs. shear strain plot for shale direct shear specimens compacted to $11 \%$ of standard proctor energy under deep loading condition.

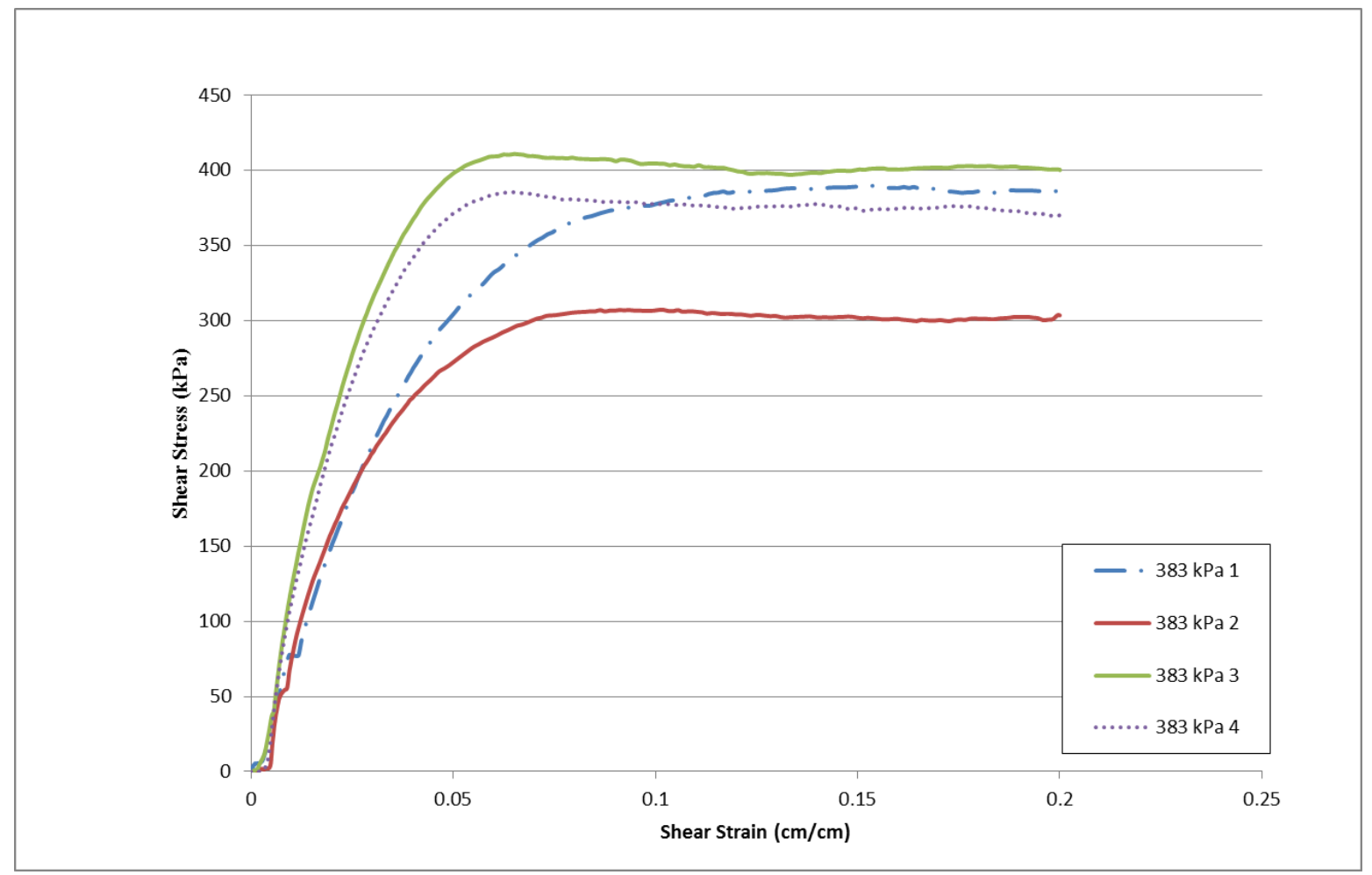

Figure A.17: Shear Stress vs. shear strain plot for shale direct shear specimens compacted to $11 \%$ of standard proctor energy under deep loading condition. 


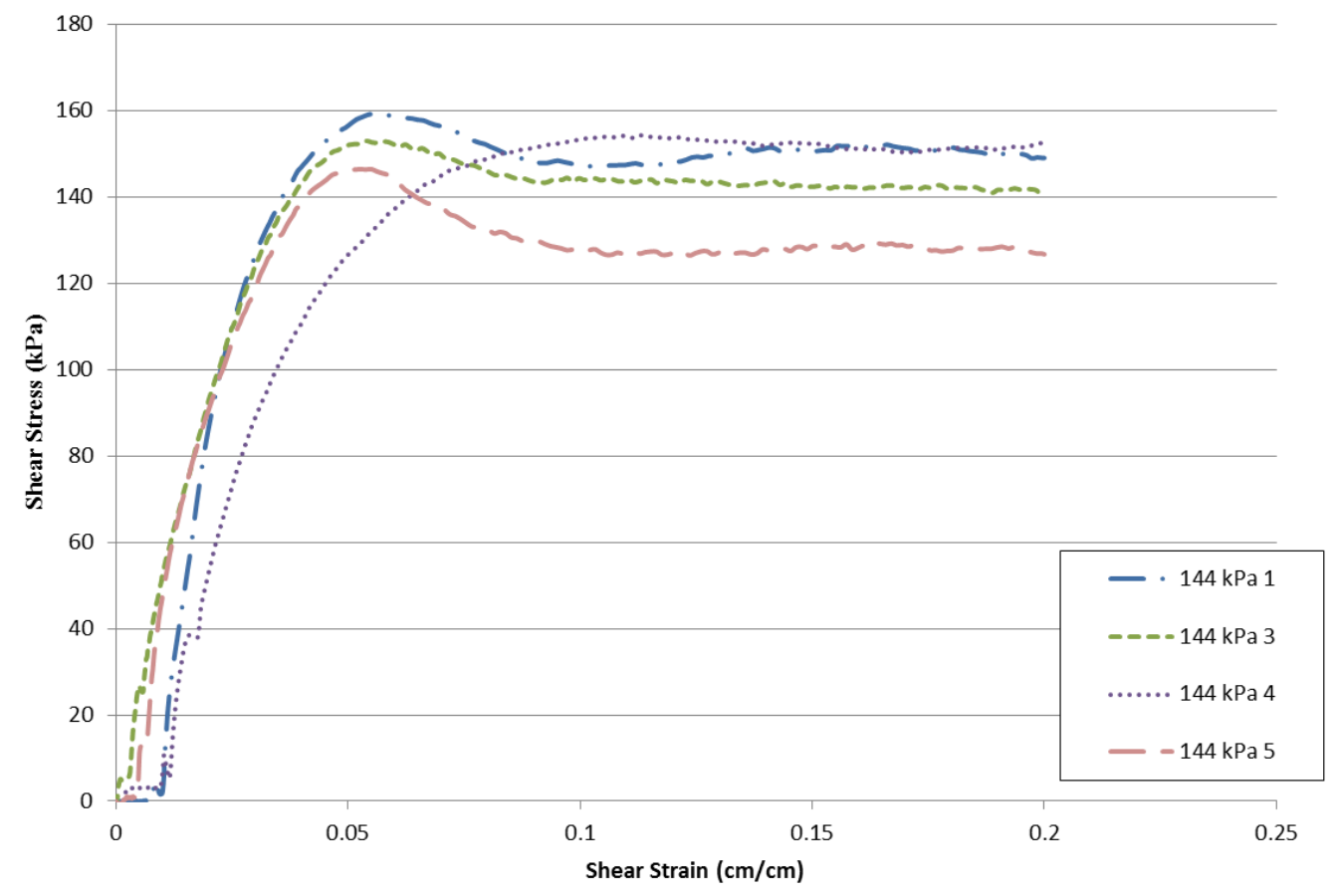

Figure A.18: Shear Stress vs. shear strain plot for shale direct shear specimens compacted to $11 \%$ of standard proctor energy under deep loading condition.

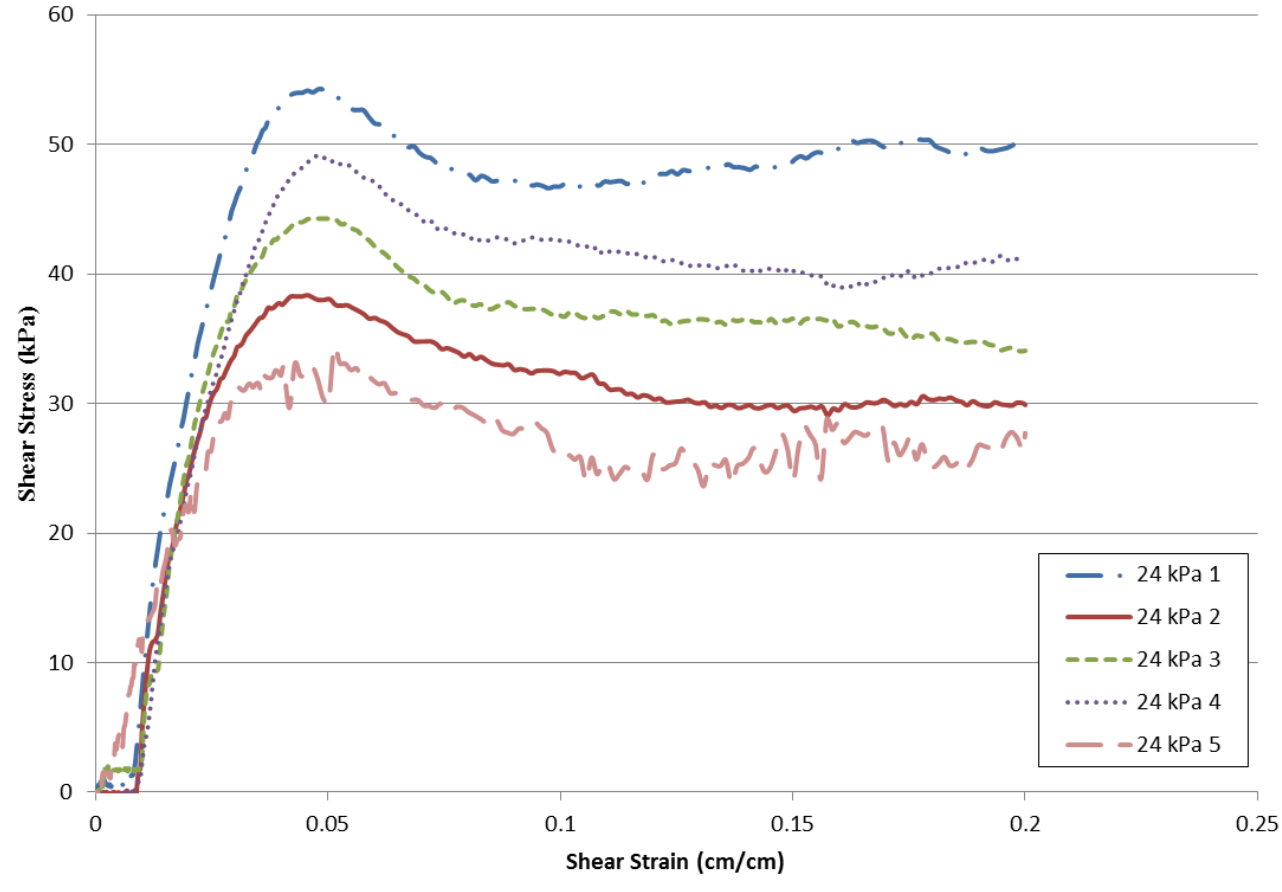

Figure A.19: Shear Stress vs. shear strain plot for shale direct shear specimens compacted to $11 \%$ of standard proctor energy under deep loading condition. 